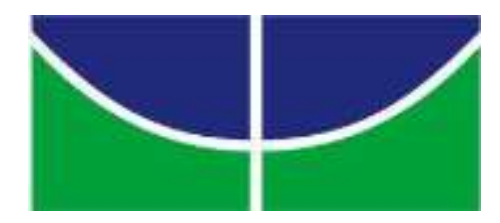

\author{
Universidade de Brasília \\ Instituto de Biologia \\ Departamento de Biologia Celular \\ Programa de Pós-Graduação em Biologia Molecular
}

\title{
Análise comparativa de complexos multienzimáticos do secretoma de Trichoderma harzianum cultivado em bagaço de cana e fontes definidas de carbono
}

Nicholas de Mojana di Cologna 


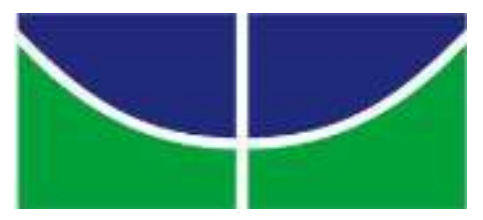

Universidade de Brasília

Instituto de Biologia

Departamento de Biologia Celular

Programa de Pós-Graduação em Biologia Molecular

Análise comparativa de complexos
multienzimáticos do secretoma de Trichoderma harzianum cultivado em bagaço de cana e fontes definidas de carbono

\section{Nicholas de Mojana di Cologna \\ Orientador: Prof. Dr. Carlos André Ornelas Ricart Laboratório de Bioquímica e Química de Proteínas (CEL/UnB)}

Dissertação apresentada ao

Programa de Pós-Graduação em Biologia Molecular da Universidade de Brasília como parte dos requisitos para a obtenção do título de Mestre em Biologia Molecular 


\section{Banca Examinadora}

Prof. Dr. Carlos André Ornelas Ricart (presidente, orientador)

Universidade de Brasília

Departamento de Biologia Celular

Laboratório de Bioquímica e Química de Proteínas

\section{Profa. Dra. Eliane Ferreira Noronha}

Universidade de Brasília

Departamento de Biologia Celular

Laboratório de Enzimologia

\section{Prof. Dr. Sébastien Olivier Charneau}

Universidade de Brasília

Departamento de Biologia Celular

Laboratório de Bioquímica e Química de Proteínas

\section{Profa. Dra. Aline Maria Araújo Martins (suplente)}

Universidade de Brasília

Departamento de Biologia Celular

Laboratório de Bioquímica e Química de Proteínas 
"Mesmo que as janelas abertas da ciência a princípio nos façam tremer de frio depois do aconchegante calor familiar dos mitos (...), no fim o ar fresco traz vigor, e os grandes espaços têm um esplendor próprio".

Bertrand Russell, no ensaio "Em que acredito" do livro "Escritos básicos de Bertrand Russell” (1925).

"É um erro capital teorizar antes de ter os dados. Insensivelmente, começa-se a distorcer os fatos para adaptá-los às teorias, em vez de fazer com que as teorias se adaptem aos fatos".

Sherlock Holmes, no conto "Um Escândalo na Boêmia”, de Sir Arthur Conan Doyle (1891). Citado por Carl Sagan no livro "O Mundo assombrado por demônios: a ciência vista como uma vela no escuro". 


\section{Agradecimentos}

O exercício da gratidão é um dos maiores valores humanos. Por isso, não posso começar essa seção sem agradecer primeiro aos seres humanos que me ensinaram esse e tantos outros valores: meus pais. Meu pai, Corrado de Mojana di Cologna, infelizmente falecido há dez anos, foi um homem muito justo, ético e valoroso. Imigrante italiano, batalhou muito para reconstruir sua vida e deixou uma forte marca no coração de todos com quem conviveu pelo seu jeito marcante e sua capacidade de ensinar lições do tipo que fica para a vida toda. Apesar das saudades, ele consegue estar presente em mim de um jeito único, e estará para o resto da minha vida. Imagino o que ele diria se pudesse ler essa dissertação. Provavelmente me perguntaria, brincando, "em que língua isso está escrito?".

Minha mãe, Marize de Souza e Silva, também merece grandes agradecimentos: me criou sempre para dar o meu melhor e respeitar o próximo, sempre enfatizando que gostaria que eu fosse feliz. Sempre brincou que me apoiaria até se eu quisesse ser astrólogo. E quando disse a ela que gostaria de me mudar para Brasília, e que faria uma graduação em Ciências Biológicas, me deu todo o apoio emocional e financeiro sem o qual eu jamais poderia ter perseguido esse sonho. Estou aqui, hoje, vivendo tudo isso, somente por causa dela e do seu amor.

Viver esse sonho também não seria possível sem que meu orientador, o professor Carlos André Ornelas Ricart, tivesse apostado em mim me dando um estágio durante uma greve de professores, no meu terceiro semestre da graduação, em 2012, e desde então garantindo que eu sempre estivesse dentro de um projeto e recebendo uma bolsa. A ele sou extremamente grato pelas inúmeras oportunidades, pelo apoio científico e emocional, por estar sempre com a porta da sala aberta e com uma piada nova para contar. Sua paciência, didática e compreensão são sua marca registrada, e com elas ele conquistou o respeito e o carinho não só meus, mas de todos do laboratório. Mais que orientador e chefe, ele sempre faz questão de mostrar que é amigo, e isso com certeza traz muita leveza para os árduos momentos característicos de qualquer pós-graduação.

Agradeço, ainda, com muito carinho a todos os professores do Laboratório de Bioquímica e Química de proteínas, que me receberam de braços abertos nessa família e sempre estiveram dispostos a tirar dúvidas, discutir resultados e filosofar por cima das xícaras de café na copa. É de momentos como esses que a ciência é feita, com o brainstorm de ideias e as epifanias que só uma xícara quente de café e uma boa companhia podem trazer. Não fiquei desapontado!

Também grandes participantes desses momentos foram os muitos amigos que fiz no Laboratório de Bioquímica e Química de Proteínas e no Laboratório de Enzimologia ao longo dessa trajetória que já está com quase cinco anos de duração. É tanta gente, dentre alunos de iniciação científica, mestrandos, doutorandos e pós-doutorandos, que fico até com receio de citar todos nominalmente e me esquecer de alguém. Ou talvez pior, não esquecer de ninguém e acabar escrevendo nomes pelas várias páginas seguintes. É o famoso "problema bom": sou grato a tantas pessoas que fico perdido no meio delas. Essas pessoas todas têm todo o meu carinho, e faço questão de dizer isso a elas em todas as oportunidades que tenho. Ninguém faz ciência sozinho, ninguém vive em sociedade 
isolado. A amizade delas me fez um pesquisador e um ser humano melhor! O auxílio para desvendar protocolos, vigiar o gel enquanto eu precisava sair, emprestar pipetas, soluções e uma mãozinha (ou duas) nos momentos em que a entropia do experimento se elevava acima do esperado, tudo isso também não passou batido.

Um agradecimento especial às equipes técnicas do Laboratório de Bioquímica e Química de Proteínas e do Laboratório de Enzimologia, engrenagens fundamentais sem as quais nada disso aqui teria acontecido. Não só pelo auxílio técnico e por ajudar a apagar incêndios (figurativa e literalmente), mas também pela amizade e pelos ensinamentos.

Parte da pesquisa foi realizada no Laboratório de Enzimologia, em colaboração com o professor Edivaldo Ximenes, e a ele também sou extremamente grato. Não só pela disponibilidade de equipamentos e reagentes, mas pelas discussões extremamente ricas e por me tratar sempre com grande atenção, como se ele fosse também meu orientador. De certa forma, certamente também foi!

Sinceros agradecimentos também aos inúmeros amigos da graduação, com quem tenho a honra de conviver até hoje, e aos amigos que fiz na pós-graduação em outros laboratórios. É sempre importante expandir nossos horizontes nas discussões, e a eles sou muito grato. Um carinho especial e em ordem alfabética, para não eleger favoritos, para: Beatriz Pinheiro, Brenda Garcia, Camila Rodrigues, Daniela Moura, Fernanda Lacerda, Flávia Martins, Guilherme Marques, Hérick Muller, Joana Rattes, Luis Janssen, Vanessa Fujiyama e Vitor Renan.

Pelo imenso suporte emocional, fora da Academia, sou também extremamente (e alfabeticamente) grato aos amigos Anna Rodrigues, Bruno Dutra, Daniel Augusto, Fellipe Ferreira, Gilmar Basílio, Jackson Pacheco, Lívia Nishino, Pedro Valadares e Victor Balbino. Um agradecimento especial à minha avó, Marly de Souza, minha segunda mãe, que sempre teve bons conselhos e palavras de carinho nos momentos difíceis.

Por fim, agradeço à Universidade de Brasília, que tem sido praticamente meu lar desde 2011; ao Programa de Pós-Graduação em Biologia Molecular, pela oportunidade de realizar este mestrado; à banca examinadora, por ter me dado a honra de aceitar o convite para participar de minha defesa; e ao Conselho Nacional de Desenvolvimento Científico e Tecnológico, por ter concedido minha bolsa de estudos durante o mestrado. 


\section{Apoio Financeiro}

Esta dissertação foi desenvolvida com o apoio financeiro do Conselho Nacional de Desenvolvimento Científico e Tecnológico (CNPq), que concedeu a bolsa de estudos; da Financiadora de Estudos e Projetos (FINEP), pela sala de Espectrometria de Massa do Laboratório de Bioquímica e Química de Proteínas da Universidade de Brasília; e da Fundação de Apoio à Pesquisa do Distrito Federal (FAPDF), que forneceu verbas pelo Programa de Apoio a Núcleos de Excelência (PRONEX). 


\section{Resumo}

O bioetanol, fonte de energia renovável, é produzido principalmente por meio da fermentação da sacarose produzida por vegetais. No entanto, os polissacarídeos presentes nos resíduos lignocelulósicos ainda contém grande quantidade de energia armazenada. Esses resíduos são considerados recalcitrantes, por serem de difícil acesso para as enzimas hidrolíticas. Ao longo da evolução, muitos microrganismos adquiriram a capacidade de mobilizar a matéria e a energia armazenadas nesse material, com um diversificado arsenal de enzimas hidrolíticas. Os fungos filamentosos se destacam dentre esses microrganismos, como por exemplo os do gênero Trichoderma. Estudos anteriores do grupo mostraram que a cepa T4 do fungo T. harzianum, quando cultivado em bagaço de cana, tem proteínas organizadas em complexos multienzimáticos no seu secretoma. $\mathrm{O}$ presente estudo visou verificar se fontes definidas de carbono presentes no bagaço de cana (celulose e xilana) seriam capazes de induzir individualmente a produção de complexos multienzimáticos, se sua composição seria a mesma dos observados em bagaço de cana ou depende da fonte de carbono e se esses complexos seriam compostos por enzimas capazes de hidrolisar várias fontes de carbono. Os fungos foram cultivados em meio sólido e posteriormente inoculados em meio líquido contendo as fontes de carbono. Após nove dias, os secretomas foram filtrados, dialisados, concentrados e submetidos a SDS-PAGE, 1D-BN-PAGE e 2D-BN/SDS-PAGE. Os resultados das análises eletroforéticas mostraram várias diferenças entre os secretomas dos diferentes tipos de meio de cultivo. No 2D-BN/SDS-PAGE, comprovou-se a presença de complexos devido à decomposição das bandas da primeira dimensão em diversos spots na segunda dimensão. A identificação por LC-MS/MS das bandas de 1D-BN-PAGE revelou a presença de complexos putativos. As proteínas identificadas com maior confiança foram discutidas, sendo que $23,7 \%$ delas eram comuns às três fontes de carbono. Essas proteínas eram todas Enzimas Ativas em Carboidratos (CAZimas), exceto uma proteína de Indução de Resistência Local e Sistêmica (ISR), a Epl1. A composição dos complexos se mostrou dependente das fontes de carbono. A presença de proteínas como a "Glycosyl hydrolase family $3 \mathrm{~N}$ terminal domain-containing protein" em quase todas as bandas de celulose e xilana, a aldose-1-epimerase em todas as bandas de xilana e duas bandas do bagaço, a feruloil esterase B somente em bandas de bagaço de cana e a proteína Epl1 em complexos de todos os tipos levanta hipóteses para a presença de proteínas organizadoras de complexos, talvez com função análoga à das escafoldina nos celulossomas. Caracterizações mais precisas dos complexos, incluindo de atividade enzimática, composição, padrões de interação e estruturas estão entre as perspectivas do trabalho. Para permitir isso, técnicas de purificação de complexos já estão em processo de implementação no laboratório, para etapas subsequentes do projeto.

Palavras-chave: Trichoderma harzianum, bagaço de cana, eletroforese nativa, complexos proteicos, espectrometria de massa, proteômica, secretoma. 


\section{Abstract}

Bioethanol, a renewable energy source, is produced mainly through the fermentation of plant sucrose. However, the polysaccharides present on the lignocellulosic residues still contains a high amount of stored energy. These residues are considered recalcitrant, because they are not easily accessed by hydrolytic enzymes. Throughout the evolution, many microorganisms developed the ability to mobilize the matter and energy stored in this material, with a diversified arsenal of hydrolytic enzymes. Filamentous fungi are a highlight among these microorganisms, for example those of the Trichoderma genus. Previous studies from our group have shown that the fungus $T$. harzianum strain T4, when grown on sugarcane bagasse, has proteins organizes in multienzyme complexes in its secretome. The present study aimed to verify if defined carbon sources present on the sugarcane bagasse (cellulose and xylan) would be able to induce individually the production of multienzyme complexes, if their composition would be the same as what was previously observed on sugarcane bagasse or carbon sourcedependent, and if these complexes would be composed of enzymes able to hydrolyze different carbon sources. The fungi were grown on solid medium and after inoculated on liquid media containing the carbon sources. After nine days, the secretomes were filtered, dialyzed, concentrated and submitted to SDS-PAGE, 1D-BN-PAGE and 2D-BN/SDSPAGE. The electrophoretic analysis results have shown several differences between the secretomes on the different growth media. On the 2D-BN/SDS-PAGE, the presence of complexes was confirmed due to the decomposition of the first dimension bands into several spots on the second dimension. Identification by means of LC-MS/MS of 1D-BNPAGE bands has revealed the presence of several putative complexes. The most reliably identified proteins were discussed, $23.7 \%$ of them being common to all three carbon sources. These proteins were all Carbohydrate-Active Enzymes (CAZymes), except for an Induced Systemic Resistance (ISR) protein, Epl1. The complexes' composition was shown to be carbon source-dependent. The presence of proteins such as the Glycosyl hydrolase family $3 \mathrm{~N}$ terminal domain-containing protein on almost all cellulose and xylan bands, aldose-1-epimerase on all xylan bands and two sugarcane bagasse bands, feruloyl esterase B only on sugarcane bagasse bands and the Epl1 protein on complexes of all kinds raises hypothesis for the presence of complex-organizing proteins, maybe with an analogous function to the cellulosome scaffoldin protein. More precise characterizations, including enzymatic activity, composition, interaction patterns and structure are among this work's perspectives. For that purpose, purification techniques for complexes are already being implemented on the laboratory, for subsequent steps of this project.

Keywords: Trichoderma harzianum, sugarcane bagasse, native electrophoresis, protein complexes, mass spectrometry, proteomics, secretome. 


\section{Sumário}

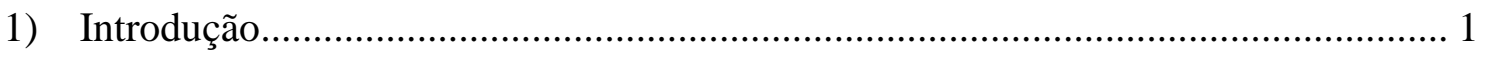

1.1) Os microrganismos e a produção sustentável de energia.................................. 1

1.2) Bagaço de cana e a degradação enzimática de seus principais componentes .... 3

1.3) Análise secretômica com enfoque em fungos filamentosos ............................. 7

1.4) Complexos proteicos e multienzimáticos: definições, técnicas de estudo e presença em secretomas fúngicos ................................................................ 13

1.5) Principais características do gênero Trichoderma .......................................... 18

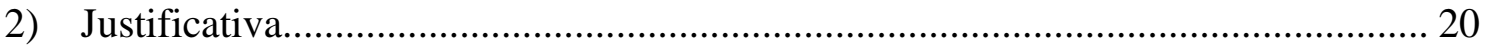

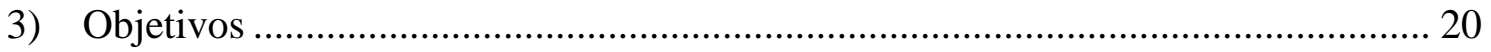

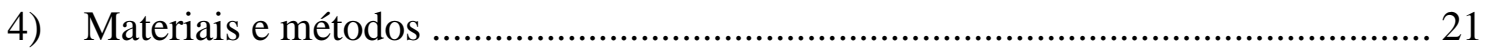

4.1) Cultura de T. harzianum e obtenção de secretomas......................................... 21

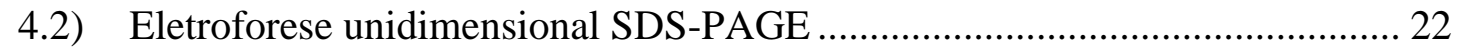

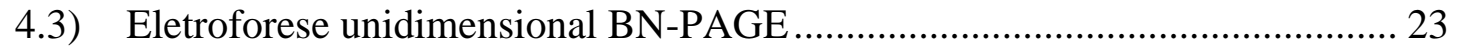

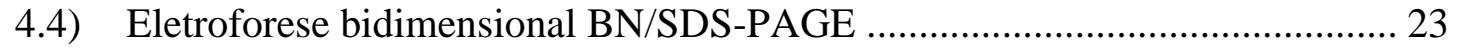

4.5) Digestão de proteínas provenientes de bandas do BN-PAGE ......................... 24

4.6) Dessalinização de peptídeos trípticos extraídos de bandas de BN-PAGE....... 24

4.7) Espectrometria de massa LC-MS/MS ......................................................... 25

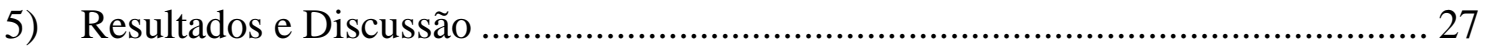

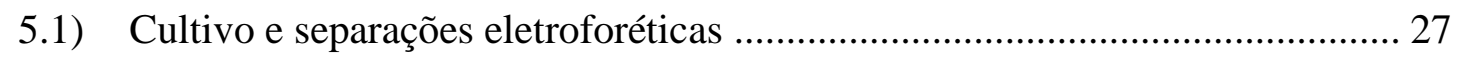

5.2) Espectrometria de massa - Identificações ...................................................... 39

5.3) Separações eletroforéticas e espectrometria de massa - Considerações e

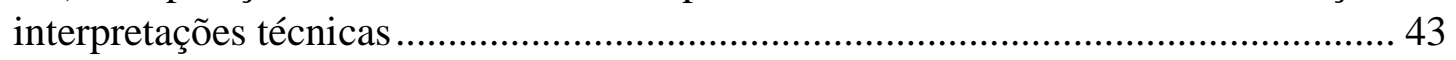

5.4) Proteínas identificadas - Discussão das identificações de maior confiança.... 50

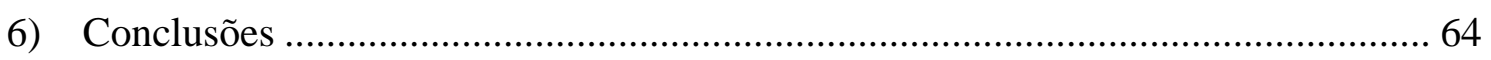

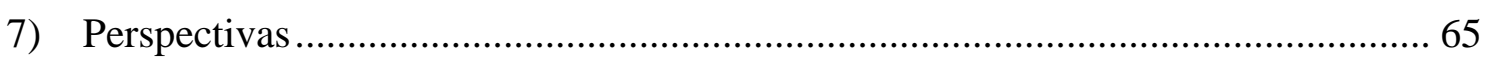

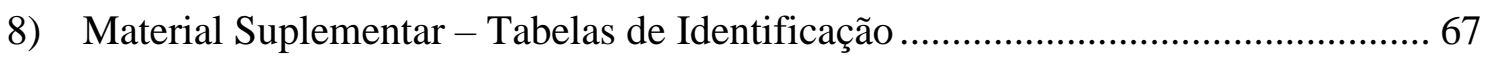

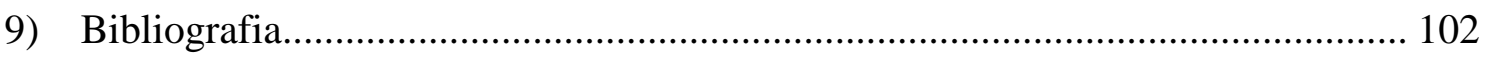




\section{Lista de Figuras}

Figura 1. Esquema geral da produção de bioetanol de primeira e segunda geração com o uso

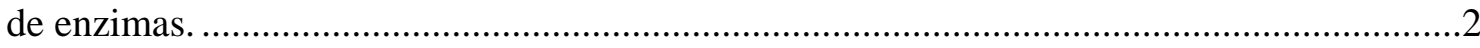
Figura 2. Representação esquemática do arranjo dos principais componentes da parede celular

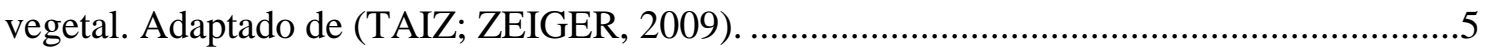

Figura 3. Modelo da parede celular vegetal com ênfase nas fibras de celulose, destacando interação com hemiceluloses e a presença de regiões cristalinas e amorfas. Adaptado de (TAIZ; ZEIGER, 2009).

Figura 4. Esquema geral da degradação enzimática da celulose e da xilana em visão esquemática. Adaptado de (ARO; PAKULA; PENTTILÄ, 2005). .....................................7

Figura 5. Representação esquemática ressaltando a diferença entre o secretoma e o exoproteoma em um modelo de bactéria Gram negativa. Adaptado a partir de (ARMENGAUD et al., 2012).

Figura 6. Visão geral das etapas da pesquisa e aplicação da conversão de biomassa baseada em secretomas.

Figura 7. Fluxograma de possíveis metodologias para a caracterização do secretoma de um fungo. Um fracionamento de peptídeos e/ou de proteínas (marcado com *) é recomendado antes ou depois da digestão, se houver, para garantir uma redução da complexidade da amostra. Os métodos de fracionamento mais comuns são a eletroforese e a cromatografia, podendo ser usados individualmente ou em combinação das mais diversas maneiras. .........12 Figura 8. Modelos para a montagem dinâmica e cooperativa de complexos proteicos. Esses processos envolvem alterações de entropia, grandes alterações na posição da cadeia principal e mudanças nas posições relativas de domínios das proteínas. Adaptado de (GAVIN;

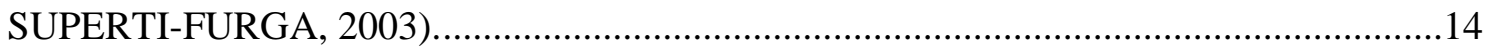
Figura 9. Predição de topologias de estrutura quaternária por meio da Tabela Periódica de Complexos Proteicos, a partir de três processos básicos sequenciais (ciclização, dimerização e adição heteromérica). A tabela apresentada é um pequeno excerto da tabela inteira. Adaptado de (AHNERT et al., 2015).

Figura 10. Princípio do uso de BN-PAGE para separar complexos proteicos acoplado a uma segunda dimensão desnaturante para separar as subunidades de cada complexo. Retirado de (SWAMY et al., 2006).

Figura 11. Estrutura de um celulossoma genérico, representando a organização das enzimas e proteínas estruturais em torno da escafoldina. O Módulo de Ligação a Carboidrato, CBM, garante a aderência à celulose. Adaptado de (SCHWARZ, 2001).

Figura 12. Fluxograma da metodologia de cultivo e obtenção de secretomas de T. harzianum realizada.

Figura 13. Fluxograma da metodologia de eletroforeses e espectrometria de massa para análise do secretoma de T. harzianum.

Figura 14. Diagrama da estratégia utilizada para a identificação das proteínas por LC-MS/MS de bandas excisadas dos géis nativos. <Adaptado do PCoM-DB (http://pcomdb.lowtem.hokudai.ac.jp), Protein Co-Migration Database for Photosynthetic Organisms. Acesso em 11/02/2017>.

Figura 15. SDS-PAGE $12 \%(\mathrm{~m} / \mathrm{v})$ dos secretomas de T. harzianum cultivado em xilana oat spelts (X), celulose microcristalina (C) ou bagaço de cana (B), com aplicação de $40 \mu \mathrm{g}$ de proteínas por poço. Os números indicam replicatas biológicas. Gel corado com Coomassie Blue Silver. 
Figura 16. BN-PAGE 5-18\% (m/v) dos secretomas de T. harzianum cultivado em xilana oat spelts (X), celulose microcristalina (C) ou bagaço de cana (B), com aplicação de $150 \mu \mathrm{g}$ de proteínas por poço. Os números indicam replicatas biológicas. Gel corado com Coomassie Blue Silver.

Figura 17. BN-PAGE 5-18\% (m/v) dos pools dos secretomas de T. harzianum cultivado em xilana oat spelts $(\mathrm{X})$, celulose microcristalina (C) ou bagaço de cana (B), com aplicação de $200 \mu \mathrm{g}$ de proteínas por poço. Gel corado com Coomassie Blue Silver. 30 Figura 18. Representação esquemática de um perfil de eletroforese bidimensional BN/SDSPAGE no qual não há nenhuma proteína complexada na amostra inicial. As proteínas migram na segunda dimensão proporcionalmente a quanto migraram na primeira dimensão, formando uma linha diagonal aproximada... .31 Figura 19. Representação esquemática de um perfil de eletroforese bidimensional BN/SDSPAGE no qual há três complexos proteicos na amostra inicial (em roxo, verde e laranja). Livres umas das outras na segunda dimensão, as subunidades migram diferencialmente e se destacam da linha diagonal. $\mathrm{O}$ alinhamento horizontal das subunidades idênticas está indicado na linha lilás.

Figura 20. BN-PAGE 10\%-18\% (m/v) dos pools dos secretomas de T. harzianum cultivado em xilana oat spelts (X), celulose microcristalina (C) ou bagaço de cana (B), com aplicação de $200 \mu \mathrm{g}$ de proteínas por poço. Gel corado com Coomassie Blue Silver............................33 Figura 21. Eletroforese bidimensional BN/SDS-PAGE do secretoma cultivado em bagaço de cana, com primeira dimensão em gradiente de poliacrilamida de 5-18\% e segunda dimensão com gradiente de poliacrilamida de $8-20 \%$. Gel corado com nitrato de prata.

Figura 22. Eletroforese bidimensional BN/SDS-PAGE do secretoma cultivado em bagaço de cana, com primeira dimensão em gradiente de poliacrilamida de $10-18 \%$ e segunda dimensão com gradiente de poliacrilamida de 8-20\%. Linha diagonal aproximada destacada em

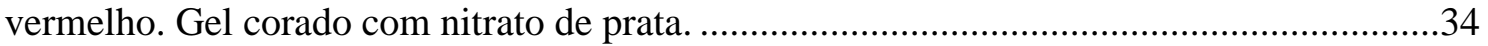
Figura 23. Eletroforese bidimensional BN/SDS-PAGE do secretoma cultivado em celulose microcristalina, com primeira dimensão em gradiente de poliacrilamida de 5-18\% e segunda dimensão com gradiente de poliacrilamida de 8-20\%. Gel corado com nitrato de prata......37 Figura 24. Eletroforese bidimensional BN/SDS-PAGE do secretoma cultivado em celulose microcristalina, com primeira dimensão em gradiente de poliacrilamida de 10-18\% e segunda dimensão com gradiente de poliacrilamida de $8-20 \%$. Gel corado com nitrato de prata.......37 Figura 25. Eletroforese bidimensional BN/SDS-PAGE do secretoma cultivado em xilana oat spelts, com primeira dimensão em gradiente de poliacrilamida de 5-18\% e segunda dimensão com gradiente de poliacrilamida de $8-20 \%$. Gel corado com nitrato de prata. ......................38 Figura 26. Eletroforese bidimensional BN/SDS-PAGE do secretoma cultivado em xilana oat spelts, com primeira dimensão em gradiente de poliacrilamida de $10-18 \%$ e segunda dimensão com gradiente de poliacrilamida de $8-20 \%$. Gel corado com nitrato de prata.......38 Figura 27. Bandas de possíveis complexos selecionadas em BN-PAGE para identificação por LC-MS/MS em LTQ-Orbitrap Elite.

Figura 28. Curva FDR das identificações experimentais de todas as 27 bandas de BN-PAGE analisadas em conjunto.

Figura 29. Distribuição dos matches de espectros peptídicos (PSMs) e validação alvo-isca para o experimento como um todo (todas as 27 bandas analisadas). Somente scores de PSMs acima de 27,8 foram considerados (indicado por linha pontilhada vertical). (a) Distribuição de scores por PSM. (b) Gráfico de dispersão dos scores por erro com relação à massa do precursor no experimento......

Figura 30. Exemplo de peptídeos-suporte para a identificação de uma proteína no experimento. A "proteína contendo domínio N-terminal da família glicosil hidrolase 3" foi 
identificada no complexo $\mathrm{C} 3$ devido à presença dos peptídeos representados pelas linhas azuis. Os resíduos destacados com fundo cinza estão na cobertura da proteína levando em conta todos os peptídeos identificados. As três PTMs consideradas na busca também estão destacadas quando presentes nas identificações (carbamidometilação de $\mathrm{C}$, deamidação de $\mathrm{N}$ e Q e oxidação de M).

Figura 31. Regressão linear simples para o fator de retenção no gel BN-PAGE 5-18\% em função do logaritmo em base 10 da massa molecular dos marcadores (citados na metodologia)

Figura 32. Regressão linear simples para o fator de retenção no gel BN-PAGE 10-18\% em função do logaritmo em base 10 da massa molecular dos marcadores (citados na metodologia).

Figura 33. Diagramas de Venn para a distribuição das proteínas em complexos nas três fontes de carbono estudadas. (A) Proteínas retiradas das tabelas de identificação sem filtros. (B) Proteínas retiradas das tabelas de identificação com filtros (sem proteínas redundantes, número de peptídeos únicos $\geq 2$ ). Imagens montadas no programa Venny 2.1 (OLIVEROS, 2015).

Figura 34. Adaptação do diagrama de Venn feito para a análise shotgun do secretoma de $T$. harzianum em quatro fontes de carbono (bagaço de cana, xilana, celulose e glicose). A glicose foi removida da figura original, com as sobreposições reordenadas para os outros conjuntos. Dados retirados de (GÓMEZ-MENDOZA et al., 2014).

Figura 35. Análise no InterPro da sequência da proteína "Glycosyl hydrolase family $3 \mathrm{~N}$ terminal domain-containing protein" identificada no experimento, com identificação de três domínios.

Figura 36. Análise no InterPro de uma proteína não-caracterizada que, por BLAST, tem 93,1\% de similaridade com a amidase de $T$. reesei.

Figura 37. Análise no InterPro de uma proteína não-caracterizada que, por BLAST, tem $84,0 \%$ de similaridade com a aldose-1-epimerase de $T$. reesei. A família está indicada por F, em vermelho, e os domínios por $\mathrm{D}$, em verde.

Figura 38. Análise no InterPro da sequência da proteína Feruloil Esterase B identificada no experimento, com identificação de dois domínios. A família está indicada por $\mathrm{F}$, em vermelho, e os domínios por $\mathrm{D}$, em verde.

Figura 39. Análise no InterPro da sequência da proteína Éster Carboxílico Hidrolase identificada no experimento, com identificação de dois domínios. Os domínios estão indicados por $\mathrm{D}$, em verde, e os sítios por $\mathrm{S}$, em roxo. Figura 40. Análise no InterPro de uma proteína não-caracterizada que, por BLAST, tem 95,9\% de similaridade com a família 5 de Glicosil Hidrolases de T. virens. A família está indicada por $\mathrm{F}$, em vermelho, e os domínios por $\mathrm{D}$, em verde. Figura 41. Análise no InterPro de uma proteína não-caracterizada que, por BLAST, tem 91,5\% de similaridade com a família 16 de Glicosil Hidrolases de T. virens. A família está indicada por $\mathrm{F}$, em vermelho, e os domínios por $\mathrm{D}$, em verde. 


\section{Lista de Tabelas}

Tabela 1. Parâmetros de buscas para os dados de espectrometria de massa LC-MS/MS. ....26 Tabela 2. Concentração proteica de cultivo dos secretomas de T. harzianum para três meios de cultivo realizados em triplicata, determinada por Qubit ${ }^{\mathrm{TM}}$ Protein Assay Kit. .27 Tabela 3. Estimativa de massa das bandas dos géis BN-PAGE analisadas por LC-MS/MS, com erro de $\pm 20 \%$.

Tabela 4. Comparação entre as massas estimadas na tabela anterior e a soma das massas das tabelas de identificação, sem filtros e com filtros. Os filtros são: remoção de redundâncias e número de peptídeos únicos $\geq 2$ (exceto quando há outros não únicos).

Tabela 5. Distribuição das 22 proteínas de mais alto score global, em ordem decrescente de cima para baixo, em cada banda analisada dos géis BN-PAGE por LC-MS/MS. As cédulas preenchidas indicam presença, e as em branco indicam ausência (de acordo com os filtros utilizados). . .53

Tabela 6. Resultado das identificações das proteínas da banda B1 do BN-PAGE. ..............67

Tabela 7. Resultado das identificações das proteínas da banda B2 do BN-PAGE. ..............67

Tabela 8. Resultado das identificações das proteínas da banda B3 do BN-PAGE. ...............68

Tabela 9. Resultado das identificações das proteínas da banda B4 do BN-PAGE. ...............69

Tabela 10. Resultado das identificações das proteínas da banda B5 do BN-PAGE. .............70

Tabela 11. Resultado das identificações das proteínas da banda B6 do BN-PAGE. .............71

Tabela 12. Resultado das identificações das proteínas da banda B7 do BN-PAGE. ..............72

Tabela 13. Resultado das identificações das proteínas da banda B8 do BN-PAGE. .............74

Tabela 14. Resultado das identificações das proteínas da banda B9 do BN-PAGE. .............74

Tabela 15. Resultado das identificações das proteínas da banda B10 do BN-PAGE. ...........75

Tabela 16. Resultado das identificações das proteínas da banda B11 do BN-PAGE. ...........75

Tabela 17. Resultado das identificações das proteínas da banda B12 do BN-PAGE. ...........76

Tabela 18. Resultado das identificações das proteínas da banda B13 do BN-PAGE. ...........77

Tabela 19. Resultado das identificações das proteínas da banda C1 do BN-PAGE. .............78

Tabela 20. Resultado das identificações das proteínas da banda C2 do BN-PAGE. .............79

Tabela 21. Resultado das identificações das proteínas da banda C3 do BN-PAGE. .............80

Tabela 22. Resultado das identificações das proteínas da banda C4 do BN-PAGE. .............82

Tabela 23. Resultado das identificações das proteínas da banda C5 do BN-PAGE. .............84

Tabela 24. Resultado das identificações das proteínas da banda C6 do BN-PAGE. .............86

Tabela 25. Resultado das identificações das proteínas da banda C7 do BN-PAGE. .............87

Tabela 26. Resultado das identificações das proteínas da banda X1 do BN-PAGE. ............90

Tabela 27. Resultado das identificações das proteínas da banda X2 do BN-PAGE. .............91

Tabela 28. Resultado das identificações das proteínas da banda X3 do BN-PAGE.............92

Tabela 29. Resultado das identificações das proteínas da banda X4 do BN-PAGE.............94

Tabela 30. Resultado das identificações das proteínas da banda X5 do BN-PAGE.............96

Tabela 31. Resultado das identificações das proteínas da banda X6 do BN-PAGE. ............98

Tabela 32. Resultado das identificações das proteínas da banda X7 do BN-PAGE...........100 


\section{Lista de Siglas e Abreviaturas}

2-DE - Eletroforese Bidimensional do tipo Isoeletrofocalização/SDS-PAGE

AA - Enzimas de Atividade Auxiliar

ACN - Acetonitrila

AS - Assinatura de Amidase (Amidase Signature)

BLAST - Basic Local Alignment Search Tool

BN-PAGE - Eletroforese em Gel de Poliacrilamida Azul Nativa

cAMP-PKA - Proteína Quinase A Dependente de AMP Cíclico

CAZimas - Enzimas Ativas em Carboidratos

CBB - Coomassie Brilliant Blue G-250

CBM - Módulo de Ligação a Carboidratos

CE - Carboidrato Esterase

DDA - Aquisição Dependente de Dados (Data Dependent Acquisition)

DTT - Ditiotreitol

ESI - Ionização por Eletronebulização (Electrospray ionization)

FDR - Taxa de Descobertas Falsas (False Discovery Rate)

FunSecKB2 - Fungal Secretome and Subcellular Proteome Knowledge Base 2.1

GELFrEE - Gel-Eluted Liquid Fraction Entrapment Electrophoresis

GH - Glicosil Hidrolase

GPI - Glicosilfosfatidilinositol

GT - Glicosil Transferase

HCD - Dissociação por Alta Energia de Colisão (Higher-energy Collisional Dissociation)

IAA - Iodacetamida

ISR - Indução de Resistência Local e Sistêmica

LC - Cromatografia Líquida

MALDI - Desorção/Ionização a Laser Assistida por Matriz (Matrix-Assisted Laser Desorption/Ionization)

MAPK - Proteína Quinase Ativada por Mitógenos

MS - Espectrometria de Massa

MS/MS - Espectrometria de Massa em Tandem

Mw - Massa Molecular

pI - Ponto Isoelétrico

PL - Polissacarídeo Liase

PMF - Peptide Mass Fingerprinting

PSM - Peptide Spectrum Match

PTM - Modificação Pós-Traducional

$\mathrm{R} f$ - Fator de Retenção

SDS - Dodecil Sulfato de Sódio

SDS-PAGE - Eletroforese em Gel de Poliacrilamida com Dodecil Sulfato de Sódio

TFA - Ácido Trifluoroacético

TOF - Tempo de Voo

TOF/TOF - Tempo de Voo em Tandem

UniProtKB - UniProt Knowledgebase 


\section{1) Introdução}

\section{1) Os microrganismos e a produção sustentável de energia}

A produção de energia é um grande fator limitante para o desenvolvimento e manutenção tecnológicos da sociedade humana. Após a Revolução Industrial, no século XVIII, houve um grande salto no consumo de energia com a substituição da energia humana ou de outros animais por mecanismos a vapor, motores de combustão interna e eletricidade. Para suprir essa demanda energética sem precedentes, a humanidade se voltou para os combustíveis fósseis. Atualmente, com todo esse avanço tecnológico e uma população mundial dez vezes maior que a do início da Revolução Industrial, o uso cotidiano (como dirigir carros, viajar de avião e manter eletrodomésticos funcionando em casa) e industrial da energia tem gerado emissões de carbono equivalentes a bilhões de cavalos trabalhando continuamente (CHU; MAJUMDAR, 2012).

Devido a esse alarmante aumento na emissão de carbono, responsável por mudanças climáticas que podem atingir proporções devastadoras, a humanidade precisa com urgência de uma nova revolução energética que possa nos fornecer energia de forma econômica, acessível e sustentável com uma substituição gradual das fontes fósseis de energia (CHU; MAJUMDAR, 2012; E. ERICKSON; JENNINGS, 2017).

Os combustíveis fósseis, além de danosos para o meio ambiente devido à poluição gerada quando queimados, são finitos, e estima-se que não durarão mais que duas gerações com o consumo que ocorre atualmente. Pensando nisso, a Comissão Mundial Sobre Meio Ambiente e Desenvolvimento, da Organização das Nações Unidas, definiu em 1987 o termo "desenvolvimento sustentável" como "desenvolvimento que procura satisfazer as necessidades da geração atual, sem comprometer a capacidade das gerações futuras de satisfazerem as suas próprias necessidades". No tocante à energia, as fontes renováveis alternativas mais viáveis para os combustíveis fósseis são a energia hidrelétrica, eólica, solar, geotérmica, das ondas marítimas e da biomassa vegetal (GOLDEMBERG, 2007; URBANIEC et al., 2017).

A biomassa vegetal é composta por biopolímeros lignocelulósicos, que são os polímeros mais abundantes do planeta. Compostos por celulose, hemiceluloses (por exemplo, a xilana) e lignina, em proporções variando conforme a espécie, estágio de desenvolvimento da planta e fatores ambientais, esses biopolímeros conferem força e estabilidade para os tecidos vegetais na parede celular. São, por isso, resistentes à degradação (recalcitrantes). No entanto, ao longo da evolução biológica, muitos microrganismos adquiriram a capacidade de contornar essa recalcitrância através da produção de enzimas que permitem a transformação da energia e da matéria neles armazenadas (ARMSTRONG et al., 2015; GUERRIERO et al., 2015).

Tais microrganismos podem ser considerados como reservatórios de informação genética com grande potencial metabólico a ser explorado (ARMSTRONG et al., 2015). Suas enzimas hidrolíticas possuem grande potencial biotecnológico tanto nas indústrias de papel, têxtil e de alimentos quanto na bioconversão de resíduos agrícolas visando à produção de açúcares fermentescíveis, que podem ser usados para a produção do chamado etanol de segunda geração (KUHAD; GUPTA; SINGH, 2011; KUMAR; SINGH; SINGH, 2008; POLIZELI et al., 2005). 
O programa de produção de etanol por meio da cana de açúcar no Brasil, estimulado no final dos anos 1970 pelo Governo Federal Brasileiro para reduzir as importações de petróleo, impulsionou o mercado de etanol do país, trazendo também grandes benefícios ambientais. $\mathrm{O}$ consumo do gás estufa $\mathrm{CO}_{2}$, pela cana de açúcar, e a sua emissão, pela queima do bioetanol produzido, geram um balanço que indica que a produção de etanol é sustentável para o meio-ambiente. Além disso, a produção de etanol pela fermentação da sacarose da cana de açúcar (etanol de primeira geração) é mais barata que outras tecnologias de produção (GOLDEMBERG, 2007).

No geral, a produção de biocombustíveis de primeira geração não é sozinha capaz de atingir todos os objetivos necessários para o desenvolvimento sustentável (substituição de combustíveis fósseis, crescimento econômico e mitigação de impactos climáticos). Isso se dá devido a fatores como competição por terras necessárias também para outras indústrias, gerando concorrência entre as indústrias e aumentos de preço (principalmente indústrias de alimentos e de rações para animais), e altos custos de produção e processamento, o que demanda subsídios governamentais para que o biocombustível seja competitivo com o petróleo (SIMS et al., 2010).

Veio daí o interesse na produção de biocombustíveis de segunda geração a partir de resíduos agroindustriais lignocelulósicos, tais como o bagaço de cana de açúcar. Apesar de a cana de açúcar ser uma exceção a esse quadro, devido à alta produção de etanol de primeira geração, é interessante poder extrair mais energia por unidade de área se além do etanol de primeira geração também for produzido etanol de segunda geração a partir do bagaço de cana (SIMS et al., 2010).

O Brasil é o maior produtor mundial de cana de açúcar. Após a colheita, a cana é moída para produção de açúcar e etanol, e o bagaço que sobra da moagem é um abundante resíduo agroindustrial rico em material lignocelulósico que normalmente é queimado nas indústrias para uma obtenção local de energia, com baixo rendimento. Se, ao invés disso, o bagaço fosse usado para a produção de etanol de segunda geração através da conversão dos polímeros da biomassa em açúcares fermentescíveis (Figura 1), o rendimento da produção de etanol poderia ser muito aumentado (CANILHA et al., 2012; GELAIN; DA CRUZ PRADELLA; DA COSTA, 2015).

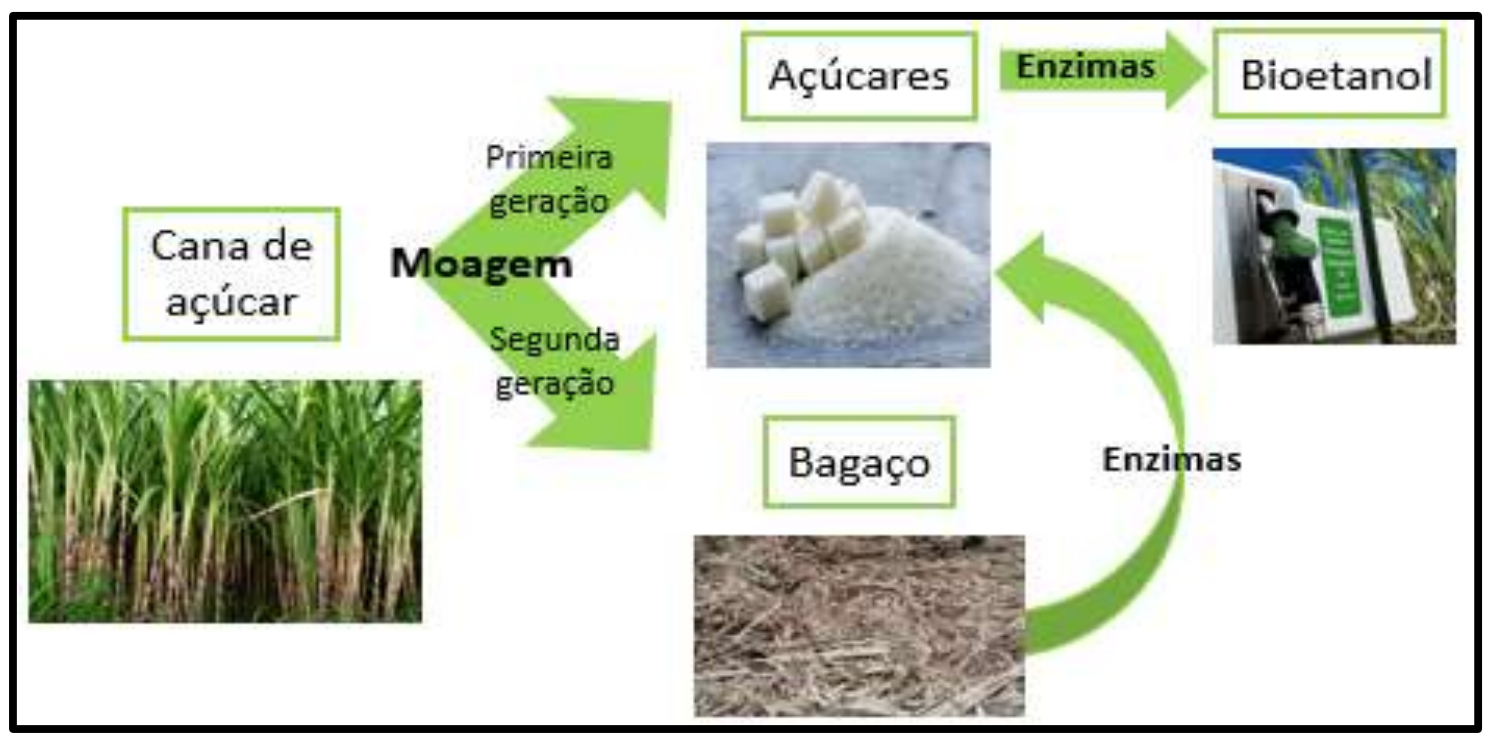

Figura 1. Esquema geral da produção de bioetanol de primeira e segunda geração com o uso de enzimas. 
Essa conversão pode ser artificialmente realizada em laboratórios de química orgânica, e são crescentes os estudos que apostam nessa área. No entanto, a despolimerização dos polissacarídeos da biomassa vegetal ainda é vista como um desafio, pois os processos são em geral caros, ocorrem em condições não-ambientes, ineficientes em escala industrial e/ou geram subprodutos não recicláveis, o que subverte a ideia do desenvolvimento sustentável (COSERI, 2017).

Ainda há muito a ser estudado pelos humanos em termos de reações artificiais de despolimerização dos polissacarídeos da biomassa vegetal. Os microrganismos, no entanto, têm bilhões de anos de experiência nessa área, e seu estudo nos revela diversas reações químicas mediadas por enzimas capazes dos mais diversos tipos de reações com altas especificidades de substratos, altas meias-vidas, altas velocidades de reação em condições ambiente e compatibilidades com o meio ambiente. Dessa forma, os produtos desejados podem ser obtidos com mais baixos custos de produção, altos rendimentos e baixa geração de resíduos. Tais enzimas, portanto, são alvo de diversos estudos que visam sua aplicação em indústrias das mais diversas. Os processos que fazem uso de células vivas ou enzimas isoladas para sintetizar bioprodutos são denominados Biotecnologia Branca (ADRIO; DEMAIN, 2014; CHAMBERGO; VALENCIA, 2016).

Processos de Biotecnologia Branca, quando acoplados a uma maquinaria industrial adequada, originam as biorrefinarias. A partir de cepas de microrganismos apropriadas para bioconversões específicas em larga escala pode-se fazer uso de ferramentas de engenharia genética para modificá-las aumentando suas propriedades desejáveis. Assim, a troca de refinarias não sustentáveis por refinarias sustentáveis vai ocorrendo em caráter mais amplo, especialmente no setor energético (HASUNUMA et al., 2013).

A possibilidade de modulação da produção de enzimas dos fungos filamentosos permite o desenvolvimento de coquetéis enzimáticos sob medida para as mais diversas vias de bioconversão (BOUWS; WATTENBERG; ZORN, 2008; RIBEIRO et al., 2012). As biorrefinarias são, portanto, um meio viável para a redução dos impactos negativos referentes ao uso de combustíveis fósseis sem que a urbanização e a economia sejam afetadas tão profundamente. Com a produção de energia de forma sustentável e a transformação de uma biomassa que é considerada um resíduo indesejável, um lixo, em um recurso com valor positivo para a economia, é possível fechar o círculo com a chamada Bioeconomia Circular e manter o desenvolvimento da sociedade (VENKATA MOHAN et al., 2016).

\section{2) Bagaço de cana e a degradação enzimática de seus principais componentes}

O uso de resíduos agroindustriais como fontes alternativas de carbono tem sido extensivamente pesquisado devido à sua alta concentração de fibras lignocelulósicas com elevada quantidade de energia proveniente da luz solar armazenada. Um desses resíduos, o mais abundante do Brasil e um dos mais abundantes do mundo, é o bagaço de cana de açúcar (gramíneas do gênero Saccharum). O objetivo de longo prazo desses estudos é encontrar formas sustentáveis e produtivas de produzir biocombustíveis, em especial o bioetanol de segunda geração, a partir dele (AMORIM et al., 2011; GOLDEMBERG, 2007; KUMAR; SINGH; SINGH, 2008; SIMS et al., 2010). 
O bagaço da cana é o resíduo obtido após a moagem do caule e extração do líquido interno. Sua estrutura química é composta principalmente por celulose, hemiceluloses e lignina. A porção hemicelulósica do bagaço de cana pode ser removida por meio de prétratamentos como hidrólise ácida e hidrotermal, liberando açúcares (principalmente Dxilose) os quais também podem ser subsequentemente fermentados a etanol. Uma diferença fundamental entre celulose e hemicelulose é que esta última é amorfa, sendo portanto de mais fácil hidrólise (CANILHA et al., 2012).

O polímero de celulose consiste em resíduos de D-glicose ligados por ligações do tipo $\beta-1,4$, formando cadeias poliméricas lineares de 8000 a 12000 monômeros de glicose. Cada par de glicoses compõe um dissacarídeo chamado celobiose. Na celulose cristalina, essas cadeias estão bem próximas devido a ligações de hidrogênio, formando estruturas cristalinas altamente insolúveis. (ARO; PAKULA; PENTTILÄ, 2005; CANILHA et al., 2012).

As hemiceluloses podem ser classificadas de acordo com os resíduos de monossacarídeos presentes na sua cadeia principal como: xilana, glicomanana e galactana. Esses heteropolissacarídeos podem ser compostos por resíduos de hexoses (Dglicose, D-galactose e D-manose), de pentoses (D-xilose e L-arabinose), acetil, ácido Dglicurônico e ácido 4-O-metil-D-glicurônico. O polímero de xilana, especificamente, consiste numa cadeia principal de monômeros de D-xilose conectados por ligações do tipo $\beta-1,4$ e de cadeias laterais de L-arabinose, D-galactose, ácido 4-O-metil-Dglicurônico e acetil, em composição variada (ARO; PAKULA; PENTTILÄ, 2005; CANILHA et al., 2012).

A lignina é uma complexa macromolécula aromática polimérica composta por três tipos de monômeros: resíduos de álcool p-cumarílico, álcool coniferílico e álcool sinapílico. Em conjunto com as hemiceluloses, a lignina envolve as fibras celulósicas da planta e age fornecendo proteção química e estrutural contra a degradação da parede celular. Como dificultam a chegada das enzimas hidrolíticas, são responsáveis por grande parte da recalcitrância da biomassa vegetal, e sua remoção facilita o processo de degradação da celulose (CANILHA et al., 2012).

O pré-tratamento do bagaço de cana é, portanto, muito importante para a produção industrial de bioetanol de segunda geração, pois garante vários pontos importantes: aumento da superfície acessível da celulose, despolimerização parcial da celulose, solubilização da hemicelulose e/ou lignina, modificação estrutural da lignina, minimização da perda de açúcares e minimização de gastos operacionais da indústria. Métodos físicos, químicos e físico-químicos dos mais diversos já foram descritos. Nesta dissertação, foi usado um método físico-químico denominado "pré-tratamento hidrotermal" ou "explosão a vapor", um dos métodos mais comuns. Nesse método, o bagaço é mantido com água em alta temperatura e alta pressão, o que promove uma hidrólise e solubilização parcial da hemicelulose. A lignina, no entanto, é pouco solubilizada nesse método (CANILHA et al., 2012).

Proteínas estruturais na parede celular adicionam resistência mecânica a ela e auxiliam a montagem adequada dos outros componentes. Já a pectina é um polissacarídeo que forma uma espécie de gel na interface da celulose com a hemicelulose, gerando um preenchimento hidrofílico que previne o colapso das fibras de celulose e determina a porosidade da parede celular. É um heteropolissacarídeo que pode ser formado por monômeros de homogalacturonana, ramnogalacturonana, arabinana e galactana (DAHER; BRAYBROOK, 2015; TAIZ; ZEIGER, 2009). 
A Figura 2 representa um esquema geral dos componentes da parede celular vegetal, evidenciando que existe uma estrutura complexa que os microrganismos precisam desconstruir para que a hidrólise possa ser feita. Ao longo da evolução, estratégias sofisticadas como os complexos multienzimáticos acabaram surgindo e se adaptando para conviver com essa realidade.

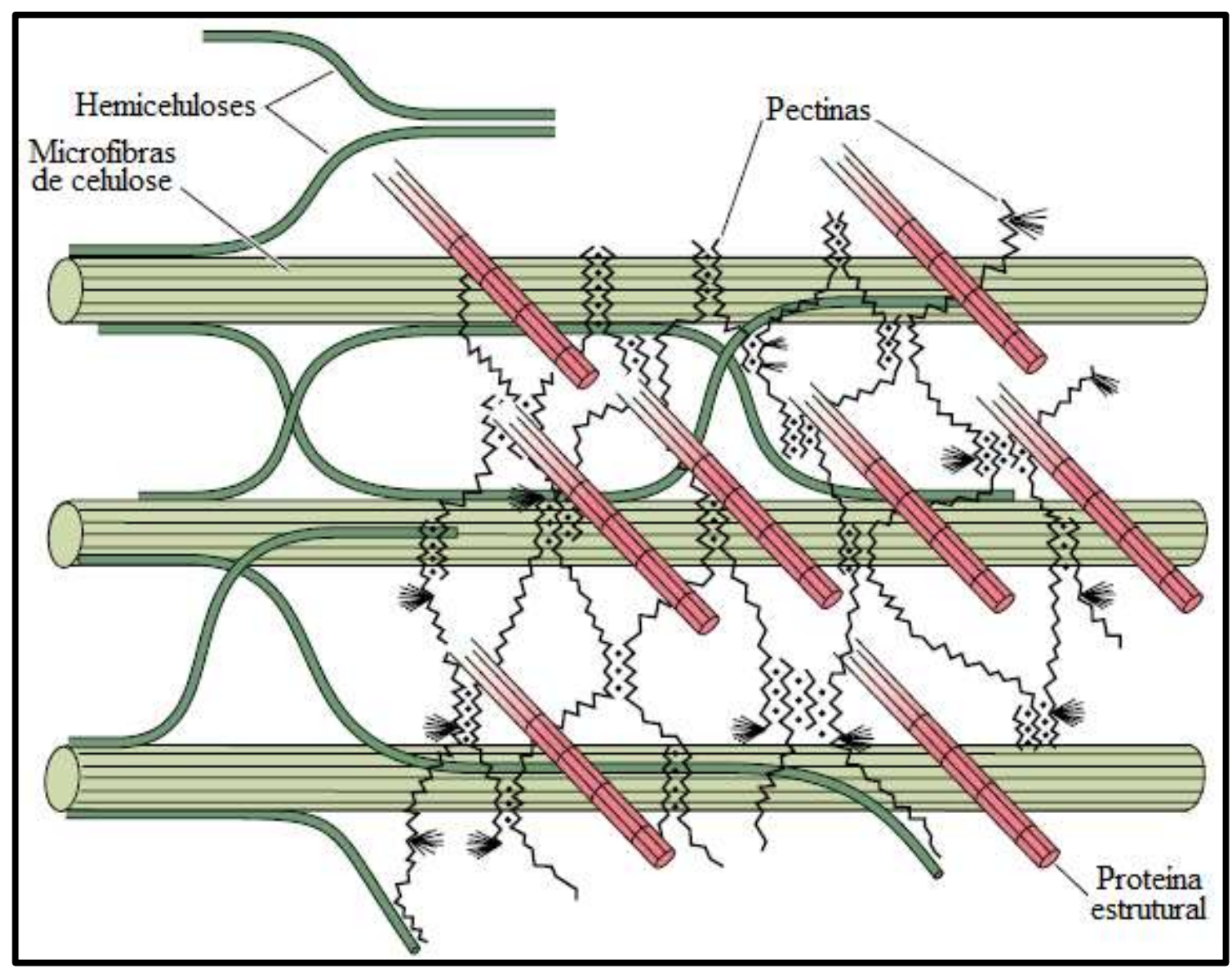

Figura 2. Representação esquemática do arranjo dos principais componentes da parede celular vegetal. Adaptado de (TAIZ; ZEIGER, 2009).

Já a Figura 3 mostra o emaranhado de celulose e hemiceluloses da parede celular com um maior destaque às fibras de celulose e sua composição, evidenciando a presença de regiões amorfas (de mais fácil acesso às enzimas hidrolíticas) e de regiões cristalinas.

A diferença na estrutura das fontes de carbono exige diferentes enzimas para a digestão e obtenção dos monômeros e de energia armazenada. Para a digestão de celulose, é necessária a ação sinérgica de várias enzimas e proteínas acessórias. As celobiohidrolases (EC 3.2.1.91) clivam a extremidade da celulose produzindo unidades de celobiose, dímero de D-glicose ligadas por ligações do tipo $\beta-1,4$. Já as endoglicanases (EC 3.2.1.4) clivam o polímero de celulose internamente principalmente nas regiões mais amorfas, provendo mais extremidades nas quais as celobiohidrolases podem agir. As $\beta$ glicosidases (EC 3.2.1.21), por fim, hidrolisam as celobioses a glicose, que é então absorvida e metabolizada pelo fungo. A swollenina, uma proteína acessória na degradação da celulase da família das expansinas, separa regiões cristalinas das fibras de celulose sem ter ação hidrolítica, apenas facilitando o acesso das outras celulases (ARO; PAKULA; PENTTILÄ, 2005). 


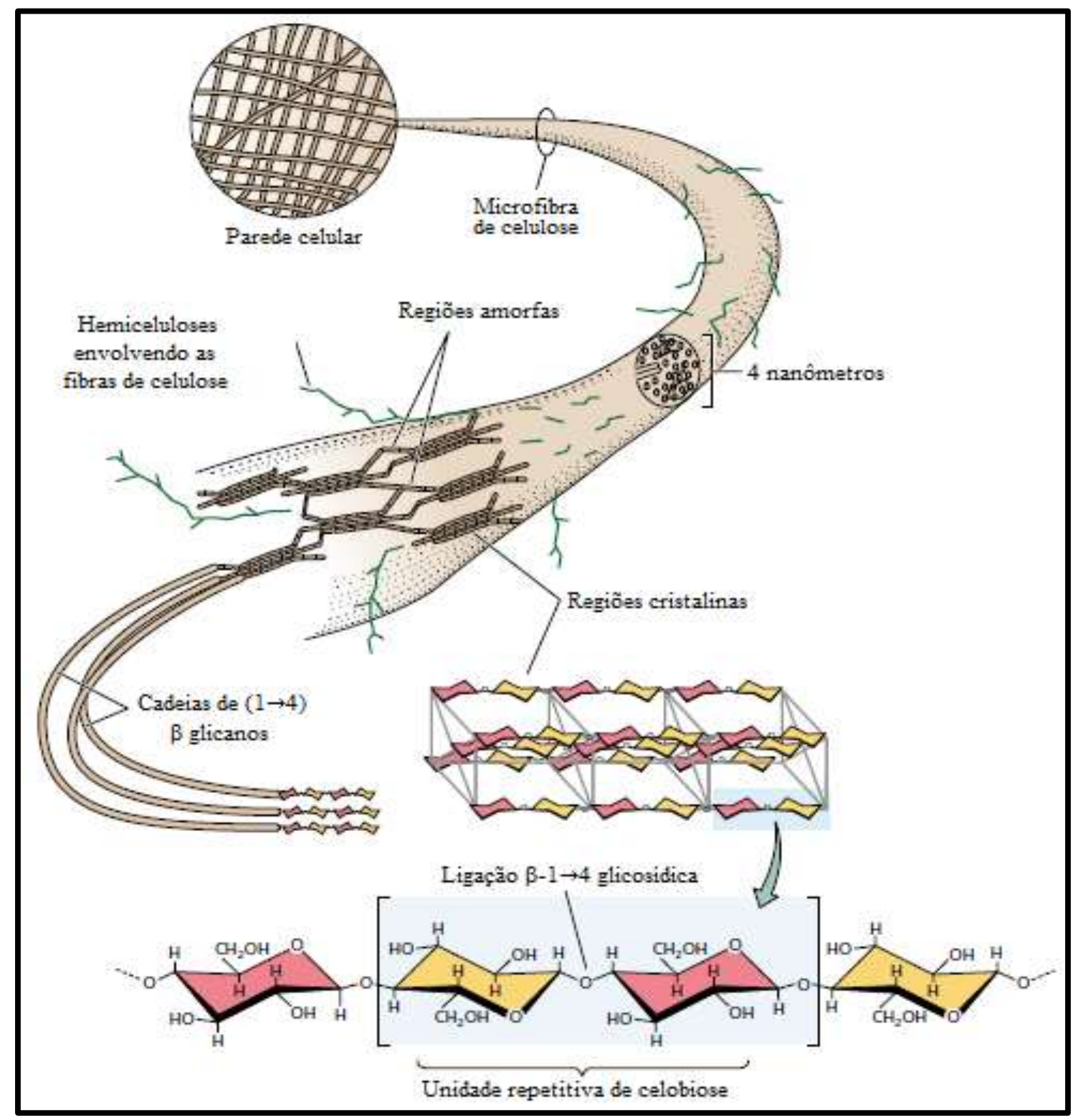

Figura 3. Modelo da parede celular vegetal com ênfase nas fibras de celulose, destacando interação com hemiceluloses e a presença de regiões cristalinas e amorfas. Adaptado de (TAIZ; ZEIGER, 2009).

Já para a digestão de xilana, outras enzimas são necessárias. As endo-1,4- $\beta$-Dxilanases (EC 3.2.1.8) clivam a cadeia principal do polímero de celulose internamente. Já as $\beta$-xilosidases (EC 3.2.1.37) hidrolisam os dímeros de D-xilose liberando monômeros de D-xilose. Diversas enzimas são responsáveis pela clivagem das cadeias laterais da xilana, como L- $\alpha$-arabinofuranosidases (EC 3.2.1.55), $\alpha$-glicuronidases (EC 3.2.1.131) e acetil xilana esterases (EC 3.1.1.72) (ARO; PAKULA; PENTTILÄ, 2005).

A ação sinérgica dessas enzimas, livres ou na forma de complexos, garante uma ação mais rápida de despolimerização. O presente trabalho se focou no efeito da celulose, da xilana e do bagaço de cana na produção de complexos multienzimáticos no fungo Trichoderma harzianum, especialmente para a degradação de celulose e de xilana. Um esquema geral para a despolimerização enzimática desses dois biopolímeros está esquematizado na Figura 4. 


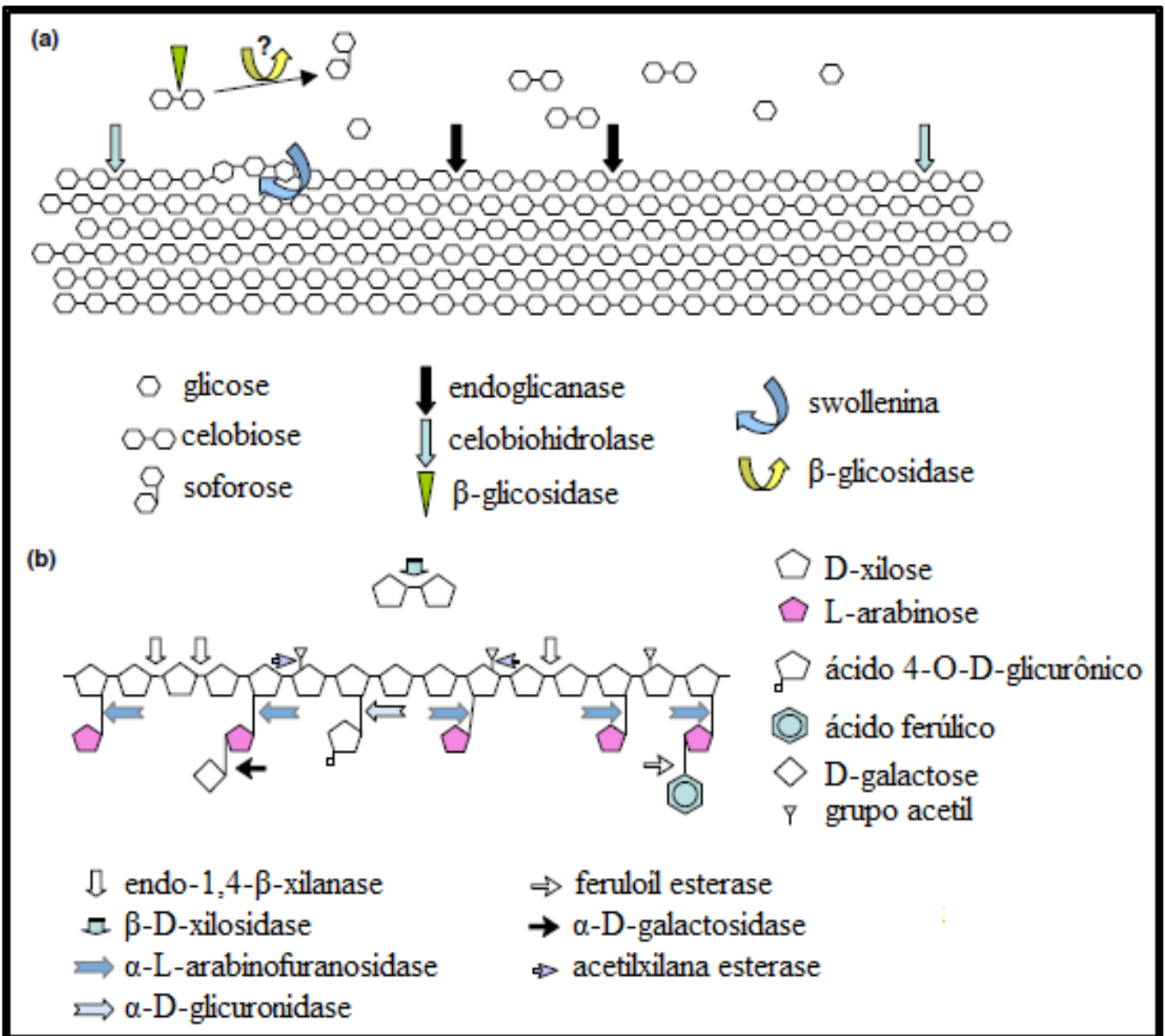

Figura 4. Esquema geral da degradação enzimática da celulose e da xilana em visão esquemática. Adaptado de (ARO; PAKULA; PENTTILÄ, 2005).

\section{3) Análise secretômica com enfoque em fungos filamentosos}

O termo "proteoma" foi criado em analogia ao termo "genoma", e é definido como o conjunto de todas as proteínas presentes em uma célula, tecido ou organismo em uma determinada condição (WILKINS et al., 1996a, 1996b). O secretoma, por sua vez, é um subproteoma que abrange o conjunto de proteínas secretadas por uma célula, tecido ou organismo em uma condição específica (TJALSMA et al., 2000). O termo secretoma é muitas vezes confundido com outro, exoproteoma, porém este último se refere ao conjunto total de proteínas extracelulares, o qual abrange não só o secretoma mas também proteínas decorrentes da lise celular e proteínas presentes em microvesículas (ARMENGAUD et al., 2012). Esses conceitos estão representados na Figura 5 em um modelo para bactérias Gram negativas.

Uma vez que diversos processos biológicos realizados por fungos filamentosos, como saprofitismo, parasitismo e interação com plantas dependem da sua habilidade de secretar enzimas e outros tipos de proteínas para o meio extracelular, uma abordagem proteômica detalhada de seus secretomas pode nos revelar aplicações biotecnológicas extraordinárias (BIANCO; PERROTTA, 2015; CHAMBERGO; VALENCIA, 2016; DE OLIVEIRA; DE GRAAFF, 2011). 


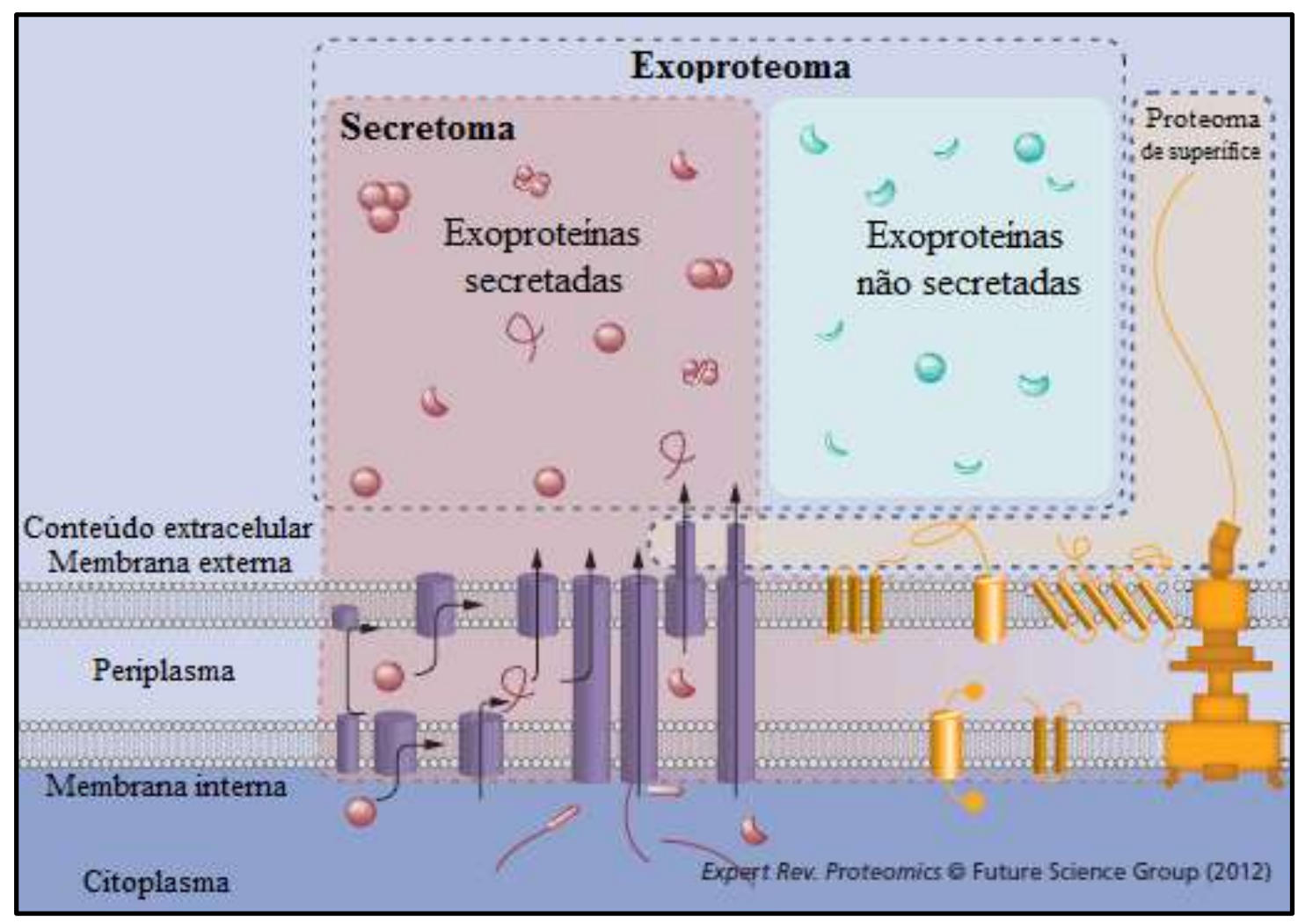

Figura 5. Representação esquemática ressaltando a diferença entre o secretoma e o exoproteoma em um modelo de bactéria Gram negativa. Adaptado a partir de (ARMENGAUD et al., 2012).

A morfologia dos fungos filamentosos e a composição de seus secretomas dependem não só das características de cada espécie, mas também das condições ambientais as quais sofrem contínuas variações (PAPAGIANNI, 2004). Proteínas estruturais secretadas usualmente são incorporadas à membrana plasmática ou à parede celular e atuam em processos de reconhecimento e interação com outros organismos, por exemplo em atividades micoparasíticas. Por outro lado, as enzimas secretadas podem ficar no periplasma, ser incorporadas à parede celular ou ir para o meio extracelular, onde podem participar da hidrólise de substratos ou do remodelamento das hifas fúngicas (PEBERDY, 1994, 1999).

A principal função das enzimas secretadas por fungos filamentosos é exodigestiva. Devido às pressões ambientais restritivas, ao longo da evolução biológica, esses organismos desenvolveram a capacidade de responder a uma ampla gama de ambientes dos mais diversos com um grande arsenal de enzimas (GIRARD et al., 2013). Portanto, a quantidade e diversidade de enzimas hidrolíticas secretadas por um fungo é altamente dependente das fontes de carbono disponíveis. Substratos lignocelulósicos, por exemplo, são eficientes indutores da secreção de celulases e hemicelulases, enquanto essa produção é diminuída por repressão catabólica quando a glicose é a única fonte de carbono fornecida. Como os polímeros são grandes demais para entrar na célula e alterar sua expressão gênica, em muitos casos pequenas moléculas que são produtos da hidrólise desses polímeros por enzimas produzidas em metabolismo constitutivo pelo fungo agem como sinalizadores (ARO; PAKULA; PENTTILÄ, 2005; BROWN; RIES; GOLDMAN, 2014). 
O secretoma de fungos filamentosos cultivados em material lignocelulósico é composto principalmente por Enzimas Ativas em Carboidratos (do inglês CarbohydrateActive Enzymes, CAZymes), que são enzimas capazes de criar, romper ou modificar ligações glicosídicas (http://www.cazy.org). Essas enzimas podem ser classificadas com base nas suas atividades como Glicosil Hidrolases (GHs), Glicosil Transferases (GTs), Polissacarídeo Liases (PLs) e Carboidrato Esterases (CEs). De caráter modular, essas enzimas costumam apresentar módulos não catalíticos responsáveis pela adesão aos carboidratos denominado Módulos de Ligação a Carboidratos (CBMs). Enzimas da classe Atividade Auxiliar (AA) são enzimas com atividades de oxirredução que atuam em conjunto com as Enzimas Ativas em Carboidratos (CANTAREL et al., 2009; LEVASSEUR et al., 2013; LOMBARD et al., 2014).

Nos últimos anos, um número crescente de projetos de sequenciamento de genomas de fungos filamentosos tem sido completado, dando grande suporte ao estudo de seus secretomas (GALAGAN et al., 2005; KUBICEK et al., 2011; LEONG et al., 2015; MARTINEZ et al., 2008; SEIDL et al., 2015; SPECHT et al., 2014; TAKAHASHINAKAGUCHI et al., 2015; YANG et al., 2015). Com ferramentas bioinformáticas, os genomas sequenciados podem fornecer predições de proteínas secretadas com base em regiões conservadas como os peptídeos sinais de secreção (CACCIA et al., 2013; CORTÁZAR et al., 2014). Contudo, um estudo secretômico baseado somente em abordagens de bioinformática pode não representar fielmente a realidade. Portanto, uma abordagem experimental baseada em Espectrometria de Massa (MS) deve ser usada em paralelo para uma descrição mais acurada do secretoma (ARMENGAUD et al., 2012; MUKHERJEE; MANI, 2013).

Ambas as abordagens, computacional e experimental, podem ser fundidas através da filtragem das proteínas experimentalmente identificadas em programas de computador que removem todas as proteínas não secretadas do exoproteoma (oriundas de lise celular ou processos apoptóticos). No entanto, nem todas as proteínas são secretadas através de mecanismos convencionais que podem ser previstos por ferramentas de bioinformática, e essa estratégia mista pode gerar perdas de resultado na caracterização dos secretomas (CACCIA et al., 2013). Um banco de dados, o FunSecKB2 (Fungal Secretome and Subcellular Proteome Knowledge Base 2.1), tem reunido dados de análises computacionais e experimentais para a anotação de diversas proteínas do secretoma e de subproteomas referentes a outras localizações subcelulares (MEINKEN et al., 2014).

A Figura 6 integra conceitos trazidos até o momento nesta Introdução. A análise bioinformática e experimental dos secretomas de diversas cepas de microrganismos, como por exemplo os fungos filamentosos, ajuda a determinar os melhores candidatos para a produção de determinados produtos nas biorrefinarias. A conversão de uma biomassa sem valor, considerada resíduo, em um produto sustentável que, ao ser degradado, pode ser reincorporado e novamente convertido em biomassa na natureza alimenta a Bioeconomia Circular, indispensável para o desenvolvimento sustentável.

Devido à alta complexidade dos secretomas, usualmente o fracionamento das proteínas e/ou peptídeos trípticos da amostra é realizado antes da espectrometria de massa, o que garante a detecção de peptídeos e proteínas com baixos níveis de expressão e aumenta o número de identificações (LY; WASINGER, 2011). 


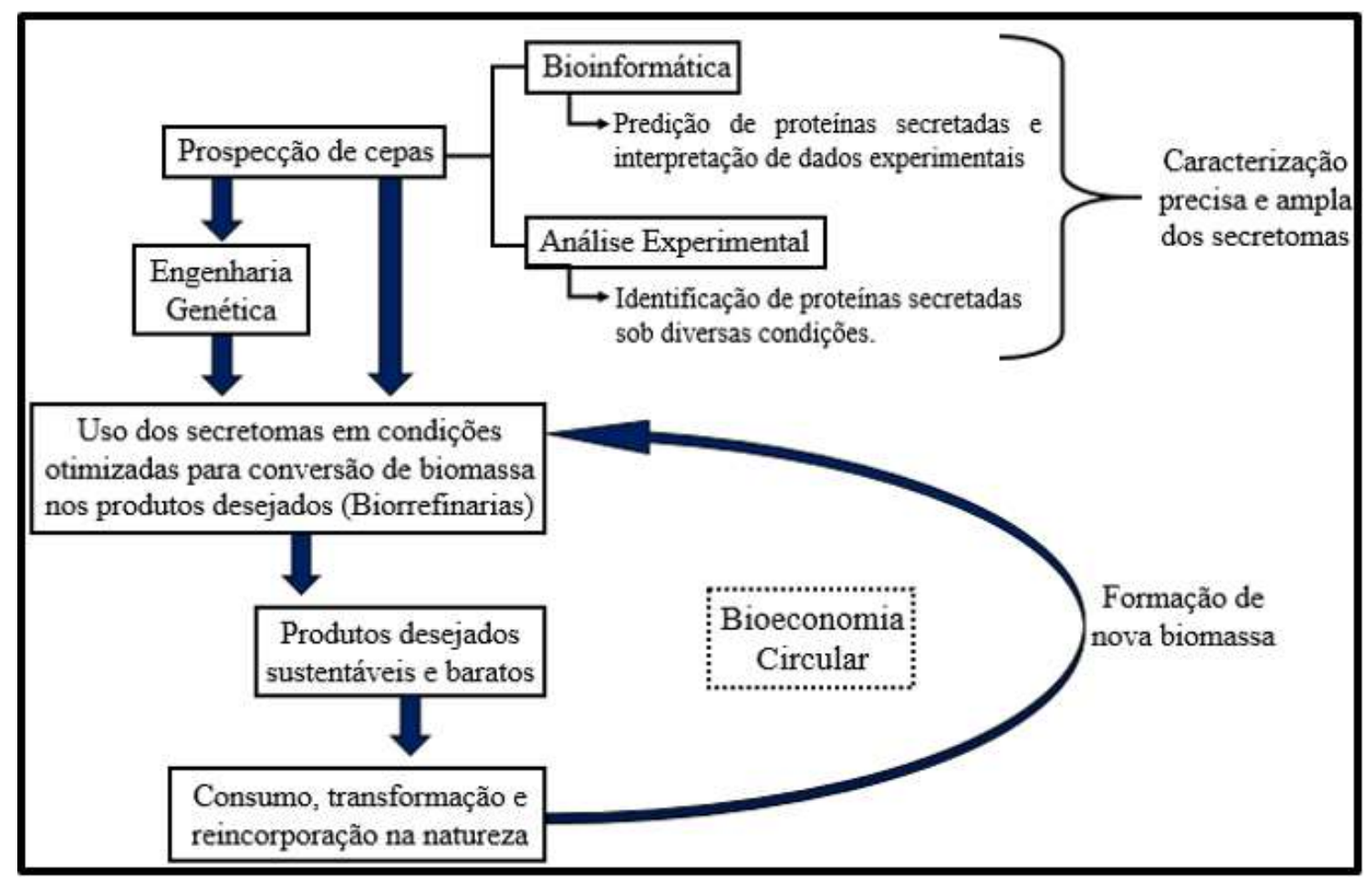

Figura 6. Visão geral das etapas da pesquisa e aplicação da conversão de biomassa baseada em secretomas.

A abordagem proteômica original para análise de secretomas era baseada na separação de proteínas por meio de uma eletroforese bidimensional (2-DE) composta por uma isoeletrofocalização na primeira dimensão seguida de uma segunda dimensão desnaturante em gel de poliacrilamida com dodecil sulfato de sódio (SDS-PAGE). As bandas resultantes, ou spots, são posteriormente analisadas por MS. A 2-DE possui alta resolução, separando milhares de proteínas em um único gel por seus pontos isoelétricos ( $p I s)$ e por suas massas moleculares (Mws), e é compatível com a MS. No entanto, a 2DE possui limitações técnicas em termos de faixa dinâmica de trabalho, sobreposição de bandas e dificuldade de separar proteínas muito hidrofóbicas ou com $\mathrm{pIs}$ extremos (muito ácidos ou muito básicos) (ROGOWSKA-WRZESINSKA et al., 2013).

A abordagem 2-DE tem sido gradualmente substituída como a principal estratégia proteômica por metodologias independentes de eletroforese que usam a Cromatografia Líquida (LC) acoplada à espectrometria de massa em tandem (MS/MS). No entanto, essa estratégia ainda tem diversos nichos na proteômica: fornecendo mapas quantitativos que facilitam a comparação entre diferentes amostras proteicas; separando isoformas proteicas; permitindo fácil estimativa de $p I s$ e Mws de proteínas; permitindo a visualização de modificações pós-traducionais (PTMs) em conjunção com MS; permitindo a visualização de degradação proteica e qualidade das amostras; dentre outros (ROGOWSKA-WRZESINSKA et al., 2013).

A abordagem LC-MS/MS mais amplamente utilizada, denominada bottom-up, consiste na digestão enzimática de todas as proteínas presentes na amostra antes da identificação dos peptídeos resultantes. Essa estratégia permite uma ampla cobertura do proteoma, gerando grandes quantidades de dados referentes a informações quantitativas e a padrões de fragmentação dos peptídeos (COX; MANN, 2011; MANN et al., 2013; ZHANG et al., 2013). 
Por outro lado, a abordagem LC-MS/MS top-down analisa as proteínas intactas e é mais vantajosa para a identificação de isoformas e para o estudo de PTMs. A abordagem bottom-up, no entanto, tem menos limitações para o fracionamento, ionização e fragmentação de amostras (ZHANG et al., 2013). As fontes de ionização mais comuns em MS são a Desorção/Ionização a Laser Assistida por Matriz (MALDI) e Ionização por Eletronebulização (ESI) (KARPIEVITCH et al., 2010).

A substituição da abordagem 2-DE-MS pela abordagem LC-MS se deve principalmente a uma maior reprodutibilidade e a um maior poder de resolução desta última. Além disso, há uma alta compatibilidade do LC-MS com a ESI e com diversos tipos de fases móveis e estacionárias na cromatografia dependendo das propriedades físico-químicas dos analitos de interesse. Técnicas cromatográficas das mais diversas podem ser usadas individualmente ou em conjunto para reduzir a complexidade da amostra antes da aplicação em MS, como cromatografia de fase reversa, troca iônica, afinidade ou exclusão molecular. Durante a separação cromatográfica, cada íon precursor intacto tem sua massa determinada, podendo ser posteriormente fragmentado para gerar informações sobre sua sequência e suas PTMs (KARPIEVITCH et al., 2010; SHI et al., 2004).

Técnicas nativas para o fracionamento de proteínas são importantes para estudos de estrutura quaternária de proteínas, como por exemplo os complexos proteicos. Um exemplo disso é o Blue Native Polyacrylamide Gel Electrophoresis (BN-PAGE), eletroforese nativa amplamente utilizada em estudos de complexos proteicos. Em combinação com uma segunda dimensão desnaturante (SDS-PAGE), é possível determinar massa molecular, estados oligoméricos, subcomplexos e pureza da amostra proteica. A identificação de proteínas que interagem umas com as outras fornece relevantes informações sobre suas possíveis funções biológicas (SCHÄGGER; CRAMER; VON JAGOW, 1994; SCHÄGGER; VON JAGOW, 1991). Também é possível a realização de uma 2-DE nativa nas duas dimensões para aumentar o grau de separação dos complexos proteicos (WEILAND et al., 2014).

Após o fracionamento e a realização de MS das amostras, a identificação das proteínas é realizada por comparação dos dados experimentais com fragmentos de peptídeos obtidos in silico com base em bancos de dados de sequências (Peptide Mass Fingerprinting, PMF) ou por sequenciamento de novo dos peptídeos e comparação das sequências encontradas com bancos de dados de sequências (LISTGARTEN; EMILI, 2005; MANN; KELLEHER, 2008).

Na Figura 7 está esquematizado um fluxograma abrangendo diversas estratégias proteômicas comuns em estudos do secretoma de fungos filamentosos. A proteômica tem uma quantidade enorme e ainda crescente de técnicas das mais diversas para permitir análises completas e abrangentes desse tipo de amostras. Essas técnicas podem ser usadas isoladamente ou em combinação umas com as outras, de maneiras criativas, para testar as hipóteses dos pesquisadores (GONZALEZ-FERNANDEZ; JORRIN-NOVO, 2012; KIM; NANDAKUMAR; MARTEN, 2007; KNIEMEYER, 2011).

A análise proteômica do secretoma de fungos filamentosos é um excelente ponto de partida para se examinar as enzimas fúngicas visando um futuro desenvolvimento de sistemas enzimáticos de baixo custo para a degradação de biomassa lignocelulósica (BOUWS; WATTENBERG; ZORN, 2008; RIBEIRO et al., 2012). 


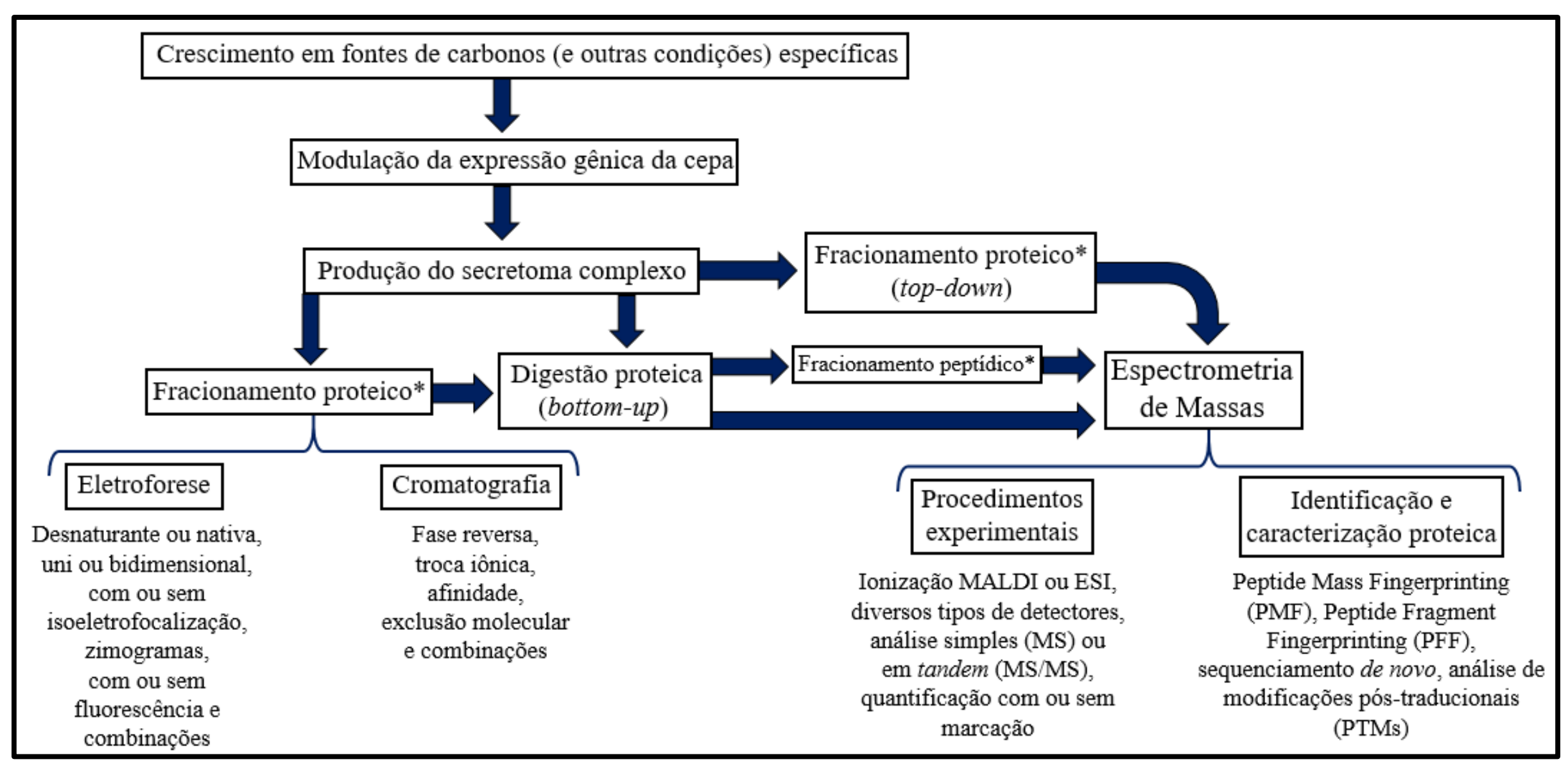

Figura 7. Fluxograma de possíveis metodologias para a caracterização do secretoma de um fungo. Um fracionamento de peptídeos e/ou de proteínas (marcado com *) é recomendado antes ou depois da digestão, se houver, para garantir uma redução da complexidade da amostra. Os métodos de fracionamento mais comuns são a eletroforese e a cromatografia, podendo ser usados individualmente ou em combinação das mais diversas maneiras. 


\section{4) Complexos proteicos e multienzimáticos: definições, técnicas de estudo e presença em secretomas fúngicos}

Complexos proteicos são formados quando da interação de pelo menos duas cadeias polipeptídicas distintas. $\mathrm{O}$ ambiente intracelular é repleto de moléculas das mais diversas, as quais entram em contato físico umas com as outras continuamente. Essas interações não covalentes (especialmente ligações de hidrogênio) têm duração, frequência e especificidade variadas, sendo muitas vezes promíscuas, de curta duração e sem importância funcional, acontecendo meramente devido à alta concentração de moléculas no meio intracelular. Muitas dessas interações, no entanto, foram evolutivamente selecionadas e originaram complexos com funções definidas. Nem todos esses complexos moleculares são estáveis, no entanto: complexos transientes também têm grande importância, especialmente na sinalização celular (MARSH; TEICHMANN, 2015).

A estrutura quaternária de um complexo proteico pode ser definida como o arranjo estrutural das suas diferentes subunidades com relação umas às outras, sendo que uma subunidade de complexo proteico pode ser definida como uma cadeia polipeptídica individual dele. Na prática, é difícil isolar complexos muito transientes e, por isso, os experimentos proteômicos costumam focar em conjuntos de proteínas co-purificadas pelo método experimental utilizado nesse isolamento (MARSH; TEICHMANN, 2015).

Os complexos proteicos podem, ainda, ser classificados em homômeros e heterômeros. Um homômero é composto por duas ou mais subunidades idênticas, enquanto um heterômero é composto por dois ou mais tipos distintos de subunidades (podendo haver mais de uma subunidade de cada tipo). As estruturas dos complexos proteicos têm sido determinadas principalmente de três modos: cristalografia de raios-X, ressonância magnética nuclear e microscopia eletrônica (MARSH; TEICHMANN, 2015).

Sendo essas interações proteína-proteína centrais à maioria dos processos biológicos, seu estudo é um dos principais alvos da Biologia Molecular. A exploração desses complexos a nível atômico auxilia a compreensão das forças intermoleculares responsáveis pelo reconhecimento molecular que garante que sejam formados. Estudos físico-químicos das interfaces proteína-proteína de diversos complexos utilizando técnicas como cocristalização de proteínas com ligantes para cristalografia e estudos estruturais e termodinâmicos de epítopos estruturais de subunidades ligadas a algum ligante permitem a caracterização energética desses complexos (MOREIRA; FERNANDES; RAMOS, 2007).

Para executar suas funções, as subunidades proteicas dos complexos não podem depender de se complexar por mera tentativa e erro. A formação dos complexos deve ser orquestrada e regulada de maneira precisa, e por isso deve seguir um código que ainda está em processo de ser compreendido. O código genético, do DNA à proteína, está elucidado, e o código do enovelamento de proteínas ainda está em intenso estudo. Em um nível acima desse, pesquisas recentes propõem a existência de um código de complexação proteica, ainda pouco compreendido, o qual envolve a coordenação dos mecanismos da expressão gênica, tradução, montagem propriamente dita, transporte e degradação de cada subunidade para garantir a execução da função (GAVIN; SUPERTI-FURGA, 2003).

Estudos da montagem de complexos proteicos como o ribossomo e o proteassoma sugerem que a montagem de um complexo seja um fenômeno dinâmico que envolve 
modificações pós-traducionais, mudanças conformacionais guiadas por hidrólise de ATP com assistência de chaperonas, recrutamento sequencial de proteínas específicas e mesmo componentes não peptídicos, ocorrendo em localizações subcelulares específicas. A cooperatividade de ligações na formação dos complexos proteicos é importante para o funcionamento do complexo pronto e para a sua estabilidade, uma vez que mudanças conformacionais e eventos alostéricos facilitam as associações subsequentes (Figura 8). Além disso, quanto mais superfícies de contato houver no complexo maior é a sua constante de afinidade (aumento exponencial) (GAVIN; SUPERTI-FURGA, 2003).

(a) Interações podem mudar a conformação das proteinas, facilitando ligações subsequentes.

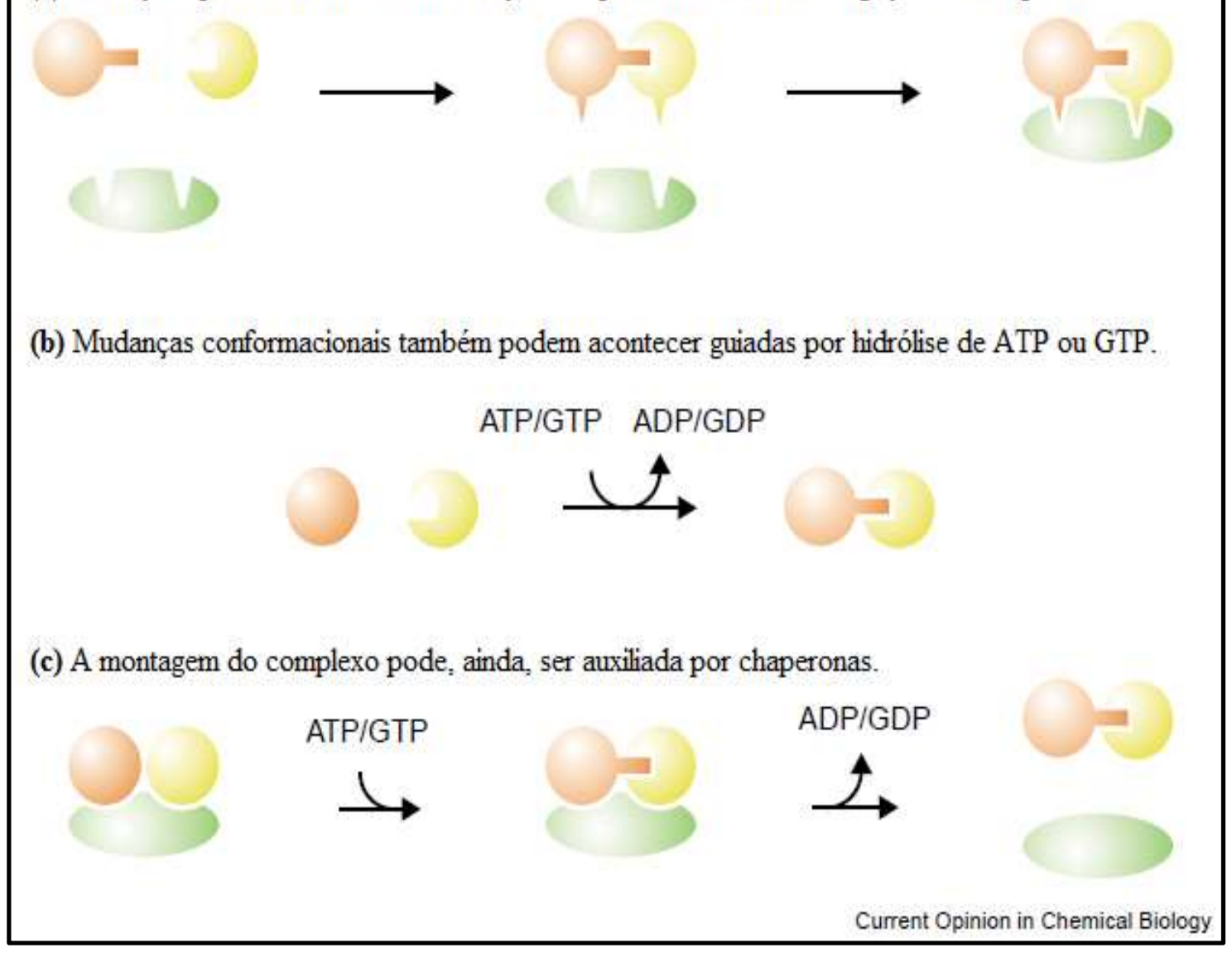

Figura 8. Modelos para a montagem dinâmica e cooperativa de complexos proteicos. Esses processos envolvem alterações de entropia, grandes alterações na posição da cadeia principal e mudanças nas posições relativas de domínios das proteínas. Adaptado de (GAVIN; SUPERTI-FURGA, 2003).

A evolução biológica da estrutura quaternária de proteínas pode ser pensada como um processo de montagem ocorrendo ao longo de uma escala de tempo evolutiva. Os mecanismos de montagem foram demonstrados como sendo evolutivamente conservados, e um estudo robusto envolvendo experimentos de LC-MS e dados da literatura sobre a estrutura e montagem de complexos proteicos sob a ótica desses mecanismos permitiu a proposição de uma "Tabela Periódica de Complexos Proteicos" (AHNERT et al., 2015).

Esse estudo concluiu que os processos de montagem de complexos podem ser classificados em três tipos básicos: dimerização, ciclização e adição heteromérica de subunidade. Por meio de combinações sistemáticas desses três tipos, são encontradas 
topologias referentes à maioria dos complexos conhecidos. As exceções são referentes a subunidades idênticas capazes de se ligar de mais de uma forma, o que gera assimetrias. A tabela proposta prevê diversas topologias de estrutura quaternária, incluindo algumas até hoje ainda não observadas mas que podem ter se desenvolvido ao longo da evolução (Figura 9). Com isso, espera-se ser possível prever a estrutura de um complexo com base em sua estequiometria e determinar quais topologias podem ser mais estáveis em trabalhos de bioengenharia de complexos (AHNERT et al., 2015).

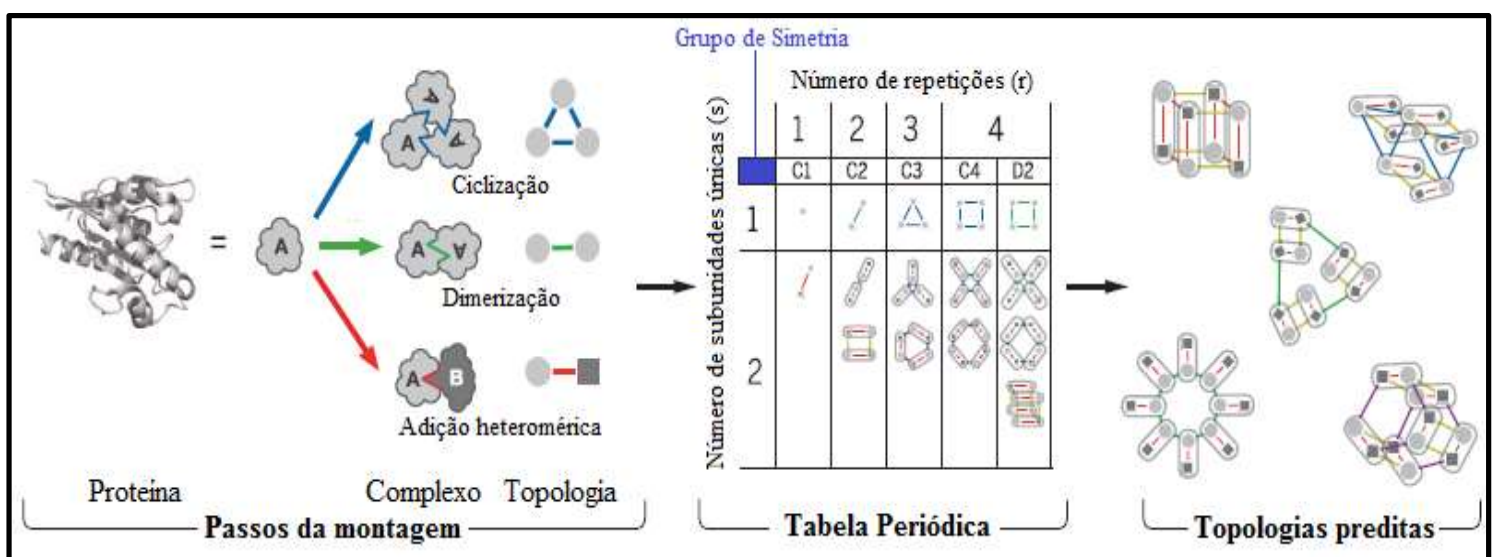

Figura 9. Predição de topologias de estrutura quaternária por meio da Tabela Periódica de Complexos Proteicos, a partir de três processos básicos sequenciais (ciclização, dimerização e adição heteromérica). A tabela apresentada é um pequeno excerto da tabela inteira. Adaptado de (AHNERT et al., 2015).

Define-se enzima multifuncional como aquela que possui mais de um centro catalítico funcional em sua cadeia polipeptídica. De forma análoga, pode-se definir um complexo multienzimáticos como o complexo proteico que possui mais de um centro catalítico funcional, em cadeias polipeptídicas separadas. Esses complexos usualmente realizam reações sequenciais ou de um mesmo processo biológico mantendo os intermediários isolados do equilíbrio de difusão da célula ou organela em que a reação está ocorrendo (SRERE, 1987).

Esse processo, denominado canalização, acoplamento, processividade, transferência direta ou transferência vetorial, garante que haja uma grande concentração dos intermediários no complexo (ainda que a concentração no meio circundante seja baixa), garantindo alta velocidade de catálise ainda que haja poucas moléculas do substrato inicial. Caso a interação do intermediário com o complexo não seja forte o bastante para impedir que parte dele se difunda para fora, dizemos que a canalização é do tipo "com vazamento" (SRERE, 1987).

Complexos multienzimáticos têm sido cada vez mais descritos nos mais diversos organismos, de procariotos a eucariotos, livres ou aderidos a porções estruturais das células. São poucas as enzimas livres nos seres vivos, e as mais diversas vias metabólicas já tiveram suas enzimas descritas como formando complexos multienzimáticos, como a glicólise, ciclo do ácido cítrico, cadeia transportadora de elétrons, ciclo da ureia, oxidação de ácidos graxos, biossíntese de ácidos nucleicos, dentre outras (SRERE, 1987).

Calcula-se que cerca de $80 \%$ dos intermediários metabólicos tenham somente um tipo de uso na célula, e por isso seria um desperdício do ponto de vista energético que esses intermediários se difundissem para toda a porção aquosa da célula. Devido à capacidade de canalização, portanto, a evolução biológica selecionou os complexos 
multienzimáticos como uma maneira extremamente eficaz de realizar as reações do metabolismo. Além disso, intermediários instáveis podem prosseguir para a próxima reação imediatamente, sem correr risco de se difundirem e serem modificados no ambiente celular (SRERE, 1987).

Além das já citadas técnicas de cristalografia de raios-X, ressonância magnética nuclear e microscopia eletrônica, há diversas outras técnicas para o estudo de complexos proteicos. Por exemplo, a Purificação por Afinidade envolve a expressão de uma subunidade com um marcador a ser selecionado numa cromatografia subsequente para purificar os complexos (FORLER et al., 2003; PUIG et al., 2001).

A purificação de complexos também pode ser atingida por fracionamento de amostras com GELFrEE (Gel-Eluted Liquid Fraction Entrapment Electrophoresis), uma eletroforese nativa em tubo (SKINNER et al., 2015). A espectrometria de massa LC-MS top-down com ou sem marcação isotópica (como iTRAQ ${ }^{\mathrm{TM}}$ ) também pode ser utilizada, com a finalidade de verificar a massa, composição, estequiometria e arranjo topológico de subunidades e estabilidade/transitividade de complexos (SOBOTT; ROBINSON, 2002; WALZTHOENI et al., 2013).

A ligação cruzada, ou crosslink, de subunidades por meio de ligações covalentes também fornece informações de alta relevância para a compreensão da montagem do complexo e superfícies de interação das subunidades (POLITIS et al., 2014; RAPPSILBER, 2011). Técnicas de engenharia genética, como ensaios Duplo Híbrido com genes repórteres cuja transcrição é ativada somente se o par de proteínas estudados se complexar, também são importantes no mapeamento do interatoma proteico e da capacidade de formação de complexos (ITO et al., 2000, 2001).

A técnica que foi utilizada nesta dissertação foi o Blue Native Polyacrylamide Gel Electrophoresis (BN-PAGE). O BN-PAGE é executado sem qualquer detergente na matriz do gel, e sua característica depende das propriedades do Coomassie Brilliant Blue G-250 (CBB). A forma aniônica do CBB liga-se aos domínios hidrofóbicos na superfície do complexo proteico (resíduos aromáticos - fenilalanina, tirosina e triptofano), causando a introdução das cargas negativas que conservam a estrutura nativa e promovem a mobilidade das proteínas para o ânodo, redução da agregação de proteínas devido à repulsão eletrostática, e conversão de proteínas hidrofóbicas em proteínas solúveis em água. Os complexos presentes na amostra são preservados e separados por sua massa molecular, com os menores migrando mais que os maiores no gel. O acoplamento de uma primeira dimensão nativa com uma segunda dimensão desnaturante (Figura 10), como o SDS-PAGE, permite que as subunidades de cada complexo sejam separadas também por massa molecular, o que permite uma ampla caracterização das interações proteicas da amostra (CAO; ZHAO; XIONG, 2016; SCHÄGGER; CRAMER; VON JAGOW, 1994; SCHÄGGER; VON JAGOW, 1991; WITTIG; BRAUN; SCHÄGGER, 2006).

A identificação das proteínas do complexo pode ser realizada posteriormente por espectrometria de massa ou ensaios com anticorpos específicos para determinadas proteínas suspeitas. Além disso, ensaios enzimáticos (zimogramas) podem permitir a visualização da atividade dos complexos da amostra no próprio gel de poliacrilamida (REISINGER; EICHACKER, 2007). 


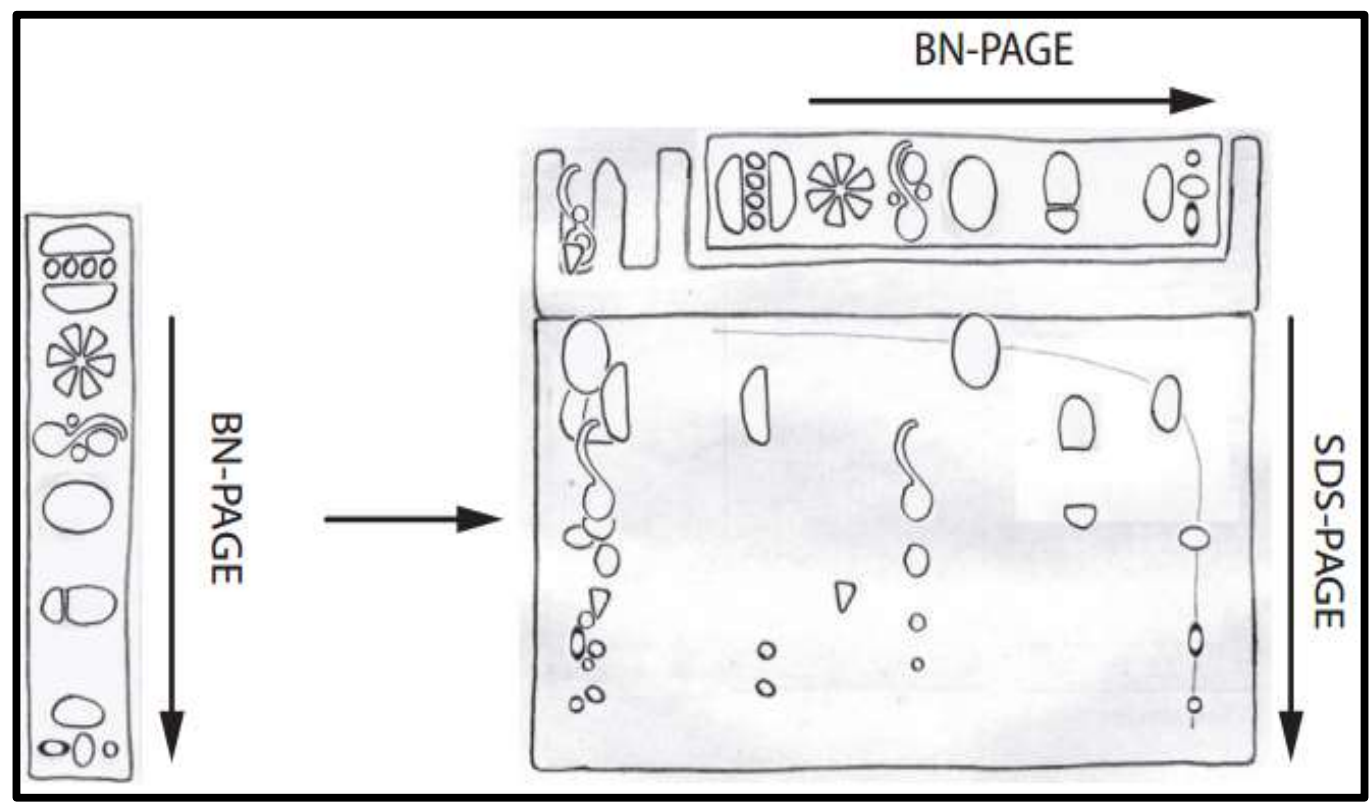

Figura 10. Princípio do uso de BN-PAGE para separar complexos proteicos acoplado a uma segunda dimensão desnaturante para separar as subunidades de cada complexo. Retirado de (SWAMY et al., 2006).

No secretoma de microrganismos aeróbios, tanto fungos quanto bactérias, é comum a secreção de enzimas hidrolíticas livres que atuam sinergicamente na degradação do substrato, como por exemplo a biomassa celulósica. Essas enzimas possuem módulos CBM para se ligar ao substrato. Já em muitos outros microrganismos anaeróbios, são descritos complexos multienzimáticos conhecidos como celulossomas que se mantém aderidos à superfície externa durante a degradação do substrato. Como as enzimas estão aderidas a uma subunidade coesina, a qual possui um módulo CBM, boa parte delas não possuem esse tipo de módulo. As proteínas do celulossoma se organizam em torno de uma proteína denominada escafoldina, do inglês scaffold, que significa "andaime" (Figura 11). O celulossoma mais bem estudado até hoje é o da bactéria Clostridium thermocellum, organismo no qual esse tipo de complexo foi identificado pela primeira vez (SCHWARZ, 2001; WILSON, 2008).

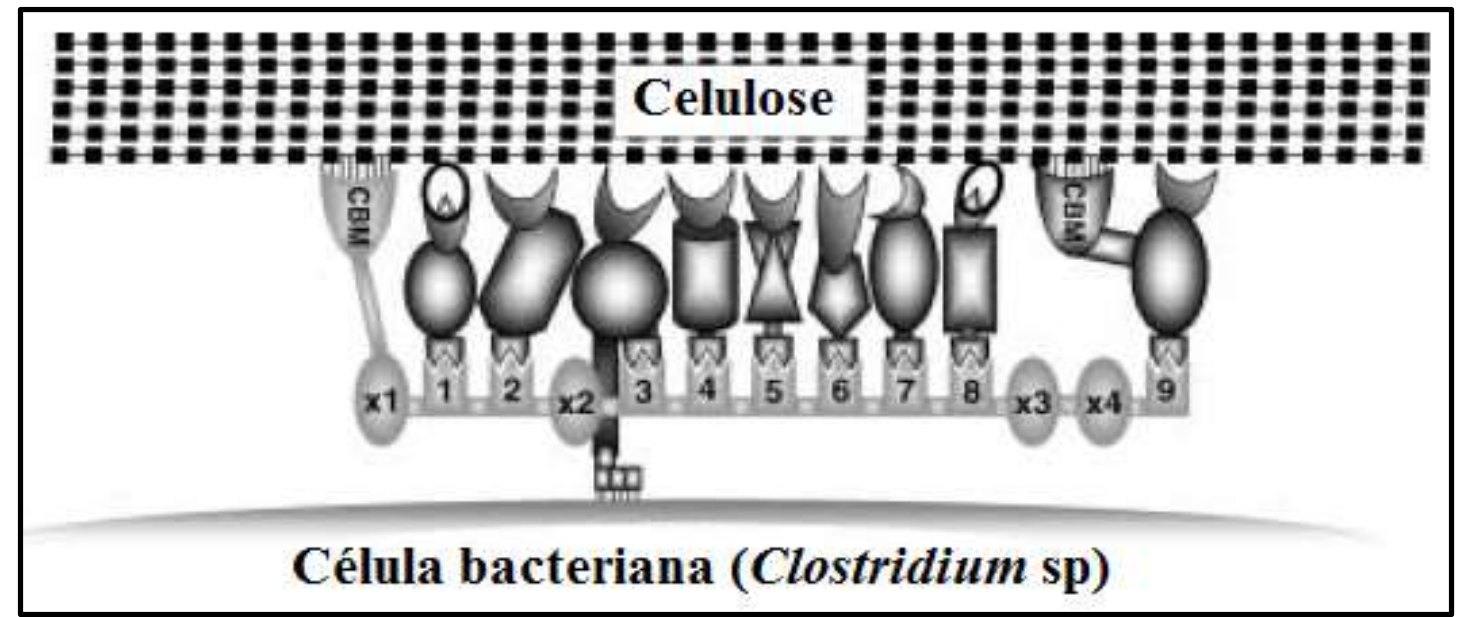

Figura 11. Estrutura de um celulossoma genérico, representando a organização das enzimas e proteínas estruturais em torno da escafoldina. O Módulo de Ligação a Carboidrato, CBM, garante a aderência à celulose. Adaptado de (SCHWARZ, 2001). 
O mecanismo de sinergia entre enzimas livres foi, até alguns anos atrás, considerado o único presente em fungos filamentosos aeróbios. No entanto, têm surgido diversos trabalhos mostrando a presença de complexos multienzimáticos nesses microrganismos, o que traz um novo enfoque para pesquisas de interesse biotecnológico. Dentre eles, Penicillium purpurogenum (GONZALEZ-VOGEL et al., 2011), Chaetomium sp (OHTSUKI et al., 2005), T. harzianum (DA SILVA et al., 2012), T. reesei (DA SILVA et al., 2015) e Clonostachys byssicola (dados em vias de publicação). Esses complexos não seguem a estrutura tradicional do celulossoma, e apresentam enzimas com variadas atividades cujos complexos formados dependem da fonte de carbono utilizada.

\section{5) Principais características do gênero Trichoderma}

Dentre os microrganismos capazes de efetuar a hidrólise do material lignocelulósico, os fungos filamentosos têm um lugar de destaque, uma vez que são capazes de produzir enzimas com altas atividades em comparação aos microrganismos em geral (MERINO; CHERRY, 2007). Além disso, são microrganismos de fácil cultivo e dotados de um arsenal bastante diversificado de enzimas (GUIMARÃES et al., 2006).

O gênero Trichoderma (teleomorfo Hypocrea), introduzido por Persoon em 1794, compreende um grupo de mais de 100 espécies identificadas por ferramentas moleculares (DRUZHININA; KOPCHINSKIY; KUBICEK, 2006; MUKHERJEE et al., 2013; SAMUELS, 2006). Esses fungos filamentosos são característicos por colonizar de forma ubíqua o material lignocelulósico na natureza. Essa eficaz capacidade de colonização se deve em grande parte ao seu eficiente uso do substrato vegetal, através da produção de diversificadas enzimas para sua degradação. A presença de diversos substratos e diferentes quantidades de luz, por exemplo, tem grande impacto na sua fisiologia e desenvolvimento (HARMAN et al., 2012; SCHMOLL; SCHUSTER, 2010).

Os fungos desse gênero são capazes de responder rapidamente a variações de estímulos ambientais como a fonte de carbono, a temperatura e a luminosidade por meio da regulação de seu crescimento, produção de conídios (esporos assexuados) e síntese de biomoléculas em geral (CARRERAS-VILLASENOR; SANCHEZ-ARREGUIN; HERRERA-ESTRELLA, 2012).

É relativamente fácil cultivar esses fungos em laboratório devido à sua natureza saprofítica, que permite que diversos tipos de fontes de carbono e energia sejam utilizados. Já como fontes de nitrogênio, podem-se usar aminoácidos, ureia e nitratos (PAPAVIZAS, 1985). As condições ótimas para o crescimento e a esporulação variam entre as espécies, mas a maioria delas é classificada como mesófila e cresce bem em pH entre 5,5 e 7,5, em temperatura entre 25 e $30^{\circ} \mathrm{C}$ e em agitação em torno de $150 \mathrm{rpm}$ (no caso de cultivo em meio líquido) (SINGH et al., 2014).

A esporulação assexuada, ou conidiogênese, desse gênero é relacionada à sobrevivência e dispersão guiadas por sinais como luz, $\mathrm{pH}$, lesões no micélio e presença de nutrientes. Esse processo é disparado por vias relacionadas à proteína quinase A dependente de AMP cíclico (cAMP-PKA), à proteína quinase ativada por mitógenos (MAPK) e às cascatas de sinalização mediadas por proteína G (CARRERASVILLASENOR; SANCHEZ-ARREGUIN; HERRERA-ESTRELLA, 2012).

As proteínas secretadas pelo gênero Trichoderma são, em sua maioria, CAZimas (principalmente Glicosil Hidrolases) capazes de degradar diversos polissacarídeos, como 
quitina, celulose e hemicelulose. $O$ arsenal enzimático do gênero é extensivamente estudado devido à sua alta aplicabilidade em bioindústrias como a têxtil, de papel, de alimento e de bebidas (FLORENCIO et al., 2014; KUMAR; SINGH; SINGH, 2008; PATHAK; BHARDWAJ; SINGH, 2014).

O potencial para a bioconversão de celulose em açúcares fermentescíveis de algumas espécies, em especial do T. reesei, tem sido amplamente estudado com relação à regulação da produção de enzimas para a indústria do bioetanol de segunda geração. Essa é a espécie mais estudada do gênero, considerada o "burro de carga biotecnológico" dele, especialmente devido ao seu altíssimo potencial de produção de celulases (FITZPATRICK et al., 2014; KATARIA; GHOSH, 2011; SCHMOLL; SCHUSTER, 2010).

Espécies micoparasíticas, como T. atroviride e T. virens, são capazes de secretar grandes quantidades de quitinases as quais são capazes de diferenciar paredes celulares fúngicas próprias de não-próprias. Enzimas proteolíticas e glicanolíticas também são presentes no secretoma de espécies de Trichoderma que atuam no controle biológico de fungos fitopatogênicos (GRUBER; SEIDL-SEIBOTH, 2012; GUIGÓN-LÓPEZ et al., 2014; LOPES et al., 2012; QUALHATO et al., 2013; VOS et al., 2015). A espécie $T$. harzianum também já está bem caracterizada como micoparasítica, sendo inclusive usado como estratégia ecológica de controle biológico devido, dentre outros fatores, à sua produção de um coquetel de enzimas com capacidade de degradação da parede celular de fungos fitopatogênicos como endoquitinase, $\beta$-glicosidase, $\alpha$-manosidase, fosfatase, $\alpha$ 1,3-glicanase e proteases (MONTEIRO et al., 2010; VITERBO et al., 2002).

Os secretomas de Trichoderma são muito ricos em proteoformas (também conhecidas como isoformas proteicas), e podem ser geralmente observadas em géis 2-DE (ADNEY et al., 2009; GÓMEZ-MENDOZA et al., 2014; LAPPALAINEN; SIIKAAHO; KALKKINEN, 2000). Por exemplo, a celulase Cel7A de T. reesei é diferencialmente glicosilada nos seus três sítios de N-glicosilação, além de apresentar diferentes padrões de fosforilação (STALS et al., 2004). Essas variações podem impactar a função da enzima, como pôde ser demonstrado num estudo da Cel7A de $T$. reesei expressa em Aspergillus niger var awamori. A enzima recombinante apresenta seis vezes mais glicanos $\mathrm{N}$-ligados que a enzima original, o que reduz sua atividade devido a uma mais alta taxa de ligações improdutivas à celulose (JEOH et al., 2008).

Outra atividade presente no gênero Trichoderma é a de indução de resistência local e sistêmica (ISR) em plantas, um ato de simbiose que eleva as defesas vegetais contra patógenos e insetos (BENÍTEZ et al., 2004; GOMES et al., 2015; HERMOSA et al., 2012; LAMDAN et al., 2015; PEREIRA et al., 2014). A família das cerato-plataninas, pequenas proteínas secretadas ricas em cisteínas, já foi descrita em diversos estudos como elicitora de defesa vegetal (GADERER; BONAZZA; SEIDL-SEIBOTH, 2014; PAZZAGLI et al., 2006). Um exemplo é a proteína Epl1 (Eliciting Plant Response-Like Protein 1), uma cerato-platanina identificada por 2-DE/MALDI-MS em T. atroviride crescido em glicose como fonte de carbono (SEIDL et al., 2006). Essa proteína é capaz de se auto organizar em interfaces líquido/sólido formando monocamadas ordenadas (BONAZZA et al., 2015) e de aumentar a polaridade de soluções e se aderir a várias formas diferentes de quitina (FRISCHMANN et al., 2013).

Proteínas similares às cerato-plataninas, como expansinas e hidrofobinas, já foram descritas em secretomas de Trichoderma sp. Hidrofobinas são proteínas anfifílicas expressas em estruturas aéreas dos fungos filamentosos, capazes de atuar como 
surfactantes (HAKANPAA et al., 2004). A expansina mais conhecida é a swollenina, uma proteína não hidrolítica isolada de $T$. reesei, que atua rompendo ligações de hidrogênio nas microfibras de celulose, aumentando o acesso das enzimas hidrolíticas à parede celular vegetal (ARANTES; SADDLER, 2010; MCQUEEN-MASON; COSGROVE, 1995; SALOHEIMO et al., 2002). Estudos com base em BN-PAGE identificaram a swollenina como parte de complexos multienzimáticos em $T$. harzianum (DA SILVA et al., 2012).

Apesar de mais conhecido pelo alto potencial de controle biológico contra fungos, o $T$. harzianum tem se tornado um promissor organismo para a produção de coquetéis enzimáticos com alta ação hidrolítica contra paredes celulares vegetais, atuando sobre diversos biopolímeros (DE CASTRO et al., 2010; DE PAULA SILVEIRA et al., 1999; DO VALE et al., 2012; MALHEIROS FERREIRA; XIMENES FERREIRA FILHO, 2004; SADHASIVAM et al., 2008).

Evidências mais recentes apontam que o gênero Trichoderma é capaz da produção de complexos multienzimáticos, o que tem grande potencial do ponto de vista da atividade pelos motivos discutidos na seção anterior desta introdução. O trabalho já citado, que identificou swollenina em complexos de T. harzianum, detectou complexos quando o fungo foi cultivado em bagaço de cana por meio de uma estratégia BN-PAGE seguido por LC-MS/MS (DA SILVA et al., 2012). Um outro trabalho, esse com T. reesei, também detectou complexos multienzimáticos por meio da mesma estratégia do trabalho anterior, em cultivos com lactose ou com galactose como fonte exclusiva de carbono (DA SILVA et al., 2015).

\section{2) Justificativa}

O bagaço de cana, como maior resíduo agroindustrial brasileiro, tem grande potencial para aumentar a produção de bioetanol de segunda geração no Brasil. Com a descoberta de que um fungo filamentoso do gênero Trichoderma, o T. harzianum, é capaz de produzir complexos multienzimáticos na presença desse resíduo, é necessário investigar mais a fundo a indução da produção desses complexos.

Sendo a celulose e a xilana os principais componentes do bagaço de cana, o presente trabalho visou investigar a produção de complexos multienzimáticos quando o fungo é crescido em cada um desses grandes componentes individualmente. A melhor compreensão do potencial do fungo para produção de complexos multienzimáticos é importante para o desenvolvimento de possíveis futuros protocolos de produção de enzimas em escala industrial a partir dessa espécie de fungo.

\section{3) Objetivos}

A pesquisa teve como objetivo geral uma maior exploração do potencial do fungo T. harzianum para a produção de complexos multienzimáticos em três fontes de carbono por meio de técnicas eletroforéticas e da espectrometria de massa bottom-up. Para atingir esse objetivo geral, os objetivos específicos (ou etapas) do presente trabalho foram: 
I) Detectar a presença de complexos multienzimáticos em $T$. harzianum fornecendo ao fungo fontes definidas de carbono (celulose microcristalina ou xilana oat spelts) e o resíduo agroindustrial complexo bagaço de cana.

II) Determinar, pela composição dos complexos multienzimáticos, se a presença dos seus subcomponentes proteicos individuais se relaciona com a fonte de carbono presente no meio de cultura.

III) Verificar se a composição dos complexos em cultivo com substratos definidos é a mesma da dos presentes em bagaço de cana.

\section{4) Materiais e métodos}

\section{1) Cultura de T. harzianum e obtenção de secretomas}

A cepa T4 de T. harzianum utilizada pertence à Coleção do Laboratório de Enzimologia (Universidade de Brasília, Brasil). Inicialmente, os conidiósporos de $T$. harzianum foram inoculados em meio sólido contendo caldo de batata (100 g.L $\left.{ }^{-1}\right)$, agarose $\left(20\right.$ g.L $\left.\mathrm{L}^{-1}\right)$ e glicose $\left(10 \mathrm{~g} . \mathrm{L}^{-1}\right)$. O cultivo se deu por sete dias em câmara de germinação Tecnal TE-4013, com fotoperíodo de 12 horas e temperatura de $28^{\circ} \mathrm{C}$. Após os sete dias de cultivo, os esporos das placas foram coletados e ressuspensos de forma homogênea em suspensão de $\mathrm{NaCl} 0,9 \%(\mathrm{~m} / \mathrm{v})$, com adição de esporos até que a concentração fosse de aproximadamente $10^{7}$ esporos $/ \mathrm{mL}$ (contagens sucessivas em câmara de Neubauer).

Para cada uma das nove amostras (uma para cada fonte de carbono, todas em triplicata), $1 \mathrm{~mL}$ dessa suspensão foi inoculado em $100 \mathrm{~mL}$ de meio líquido de cultivo acondicionado em Erlenmeyer de $500 \mathrm{~mL}$. O meio líquido continha os seguintes componentes: $\mathrm{KH}_{2} \mathrm{PO}_{4}\left(680 \mathrm{mg} . \mathrm{L}^{-1}\right), \mathrm{K}_{2} \mathrm{HPO}_{4}\left(870 \mathrm{mg} . \mathrm{L}^{-1}\right),\left(\mathrm{NH}_{4}\right)_{2} \mathrm{SO}_{4}\left(1,7\right.$ g.L $\left.{ }^{-1}\right), \mathrm{KCl}$ (200 mg.L $\left.\mathrm{L}^{-1}\right), \mathrm{CaCl}_{2}\left(200 \mathrm{mg} . \mathrm{L}^{-1}\right), \mathrm{MgSO}_{4} \cdot 7 \mathrm{H}_{2} \mathrm{O}\left(200 \mathrm{mg} . \mathrm{L}^{-1}\right), \mathrm{FeSO}_{4}\left(2 \mathrm{mg} . \mathrm{L}^{-1}\right), \mathrm{MnSO}_{4}$ $\left(2 \mathrm{mg} \cdot \mathrm{L}^{-1}\right), \mathrm{ZnSO}_{4}\left(2 \mathrm{mg} \cdot \mathrm{L}^{-1}\right)$, glicose $\left(1 \mathrm{~g} \cdot \mathrm{L}^{-1}\right)$ e a fonte de carbono específica da amostra $\left(9\right.$ g. $\left.\mathrm{L}^{-1}\right) . \mathrm{O} \mathrm{pH}$ foi ajustado para $6,0 \mathrm{com} \mathrm{HCl}$. As fontes específicas de carbono foram celulose microcristalina Avicel®, xilana oat spelts e bagaço de cana pré-tratado hidrotermalmente. O pré-tratamento hidrotermal consistiu em autoclavagem a $121^{\circ} \mathrm{C}$ por duas horas, lavagem em água corrente para remoção de polissacarídeos da hemicelulose solubilizados, secagem a $65^{\circ} \mathrm{C}$ por duas horas e moagem em moinho de bancada.

O protocolo original do cultivo foi modificado para compreender glicose de modo que a soma das concentrações de fonte de carbono fosse $10 \mathrm{~g} . \mathrm{L}^{-1}$, para facilitar $\mathrm{o}$ desenvolvimento inicial do micélio (SUÁREZ et al., 2005). A presença de glicose, apesar de reprimir a expressão de genes para celulases e xilanases num momento inicial do cultivo (ARO; PAKULA; PENTTILÄ, 2005), auxiliou na germinação dos esporos e no início do crescimento do fungo.

As culturas em meio líquido foram incubadas por nove dias em shaker rotatório a $120 \mathrm{rpm}$ e $28^{\circ} \mathrm{C}$. Posteriormente, os secretomas foram separados dos micélios por filtração a vácuo (papel de filtro Whatman $\mathrm{n}^{\circ} 1$ ), dialisados ( $\operatorname{sacos}$ de diálise de nitrocelulose com cutoff de $12 \mathrm{kDa}$ ), liofilizados e ressuspendidos em água milli-Q. As diálises foram realizadas a frio com quatro repetições de uma hora cada, com troca do saco de diálise entre cada repetição. $O$ frio visou a redução da atividade enzimática dos secretomas, o que em conjunto com a troca dos sacos de diálise garantiu que não houvesse 
vazamentos (hidrólise enzimática da nitrocelulose dos sacos de diálise). As amostras foram armazenadas congeladas a $-20^{\circ} \mathrm{C}$, entre os experimentos.

Os secretomas brutos e liofilizados foram quantificados com Qubit Protein Assay Kit no fluorômetro Qubit ${ }^{\circledR} 2.0$ (Life Technologies). Após as eletroforeses iniciais, que demonstraram a reprodutibilidade das replicatas biológicas, passou-se a trabalhar com um pool de cada tipo de secretoma (mistura de volumes iguais do secretoma liofilizado). A metodologia de cultivo e obtenção de secretomas está esquematizada na Figura 12, enquanto as metodologias subsequentes se encontram esquematizadas na Figura 13 e na Figura 14.

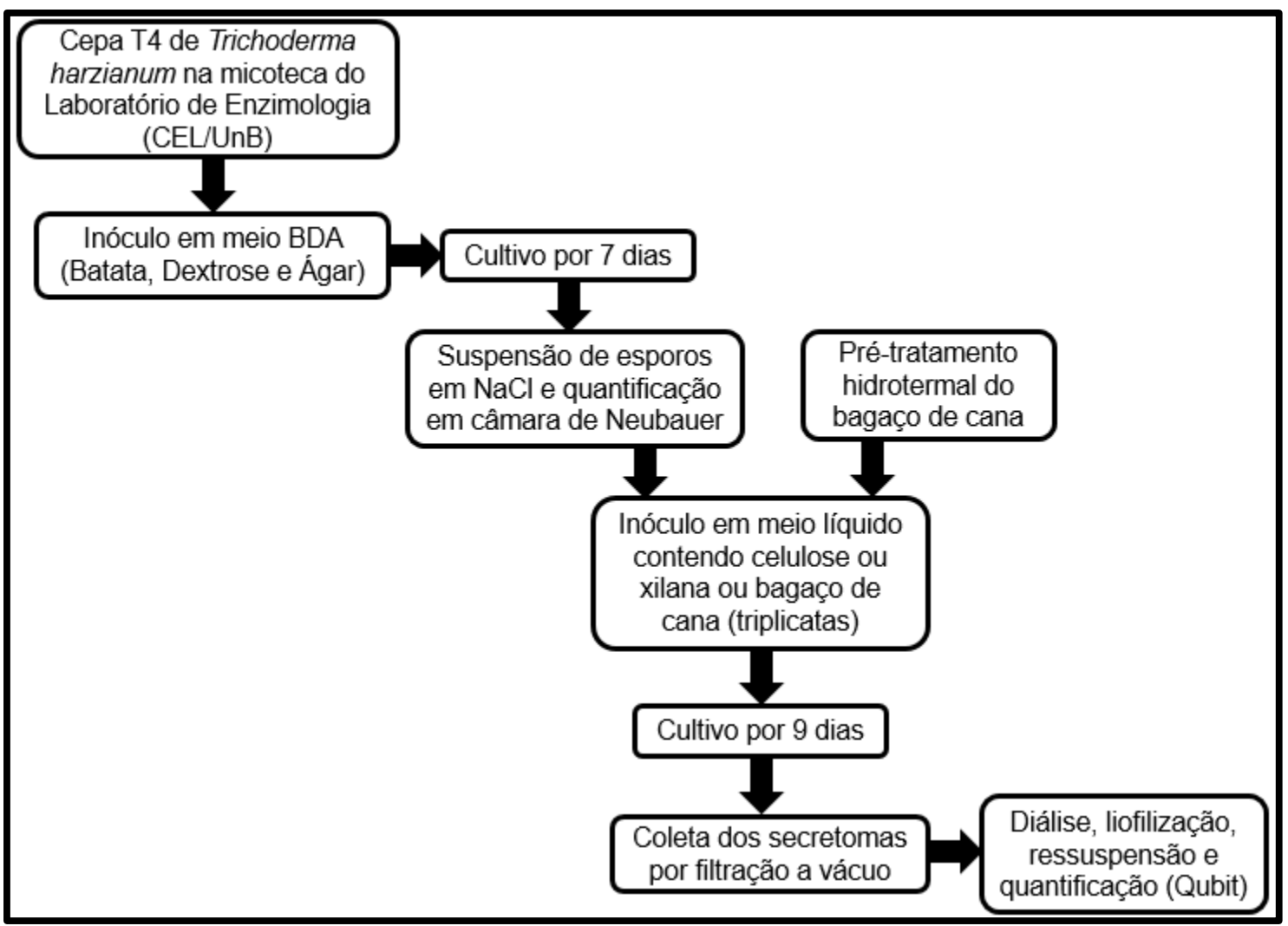

Figura 12. Fluxograma da metodologia de cultivo e obtenção de secretomas de $T$. harzianum realizada.

\section{2) Eletroforese unidimensional SDS-PAGE}

A eletroforese SDS-PAGE (Sodium Dodecyl Sulfate Polyacrilamide Gel Electrophoresis) consistiu em gel separador de poliacrilamida $12 \%(\mathrm{~m} / \mathrm{v})$ de $0,75 \mathrm{~mm}$ de espessura e em gel concentrador de poliacrilamida $5 \%(\mathrm{~m} / \mathrm{v})$. As amostras $(40 \mu \mathrm{g}$ de proteínas) foram preparadas em SDS $2 \%(\mathrm{~m} / \mathrm{v})$, glicerol $10 \%(\mathrm{v} / \mathrm{v})$, azul de bromofenol $0,01 \%(\mathrm{~m} / \mathrm{v})$ e $60 \mathrm{mM}$ Tris/HCl pH 6,8. Então, foram fervidas em água por cinco minutos e aplicadas no gel. A corrida foi realizada a $25 \mathrm{~mA}$ e a $19^{\circ} \mathrm{C}$, por cerca de quatro horas, em um aparato vertical de eletroforese SE 600 (Hoefer, Inc., San Francisco, CA, USA). O tampão de corrida utilizado foi $25 \mathrm{mM}$ Tris, $192 \mathrm{mM}$ glicina e SDS 0,1\% (m/v)/HCl pH 8,8 (LAEMMLI, 1970).

Os marcadores moleculares utilizados foram fosforilase b $(97 \mathrm{kDa})$, albumina de soro bovino (66 kDa), ovalbumina (45 kDa), anidrase carbônica (30 kDa), inibidor de 
tripsina de soja $(20 \mathrm{kDa})$ e $\alpha$-lactalbumina $(14,4 \mathrm{kDa})$. Após a eletroforese, o gel foi corado com solução Coomassie Blue Silver (CANDIANO et al., 2004).

\section{3) Eletroforese unidimensional BN-PAGE}

A análise dos secretomas por eletroforese BN-PAGE (Blue Native Polyacrylamide Gel Electrophoresis) foi realizada conforme protocolo para proteínas hidrossolúveis (SCHÄGGER; CRAMER; VON JAGOW, 1994). As amostras foram preparadas em tampão $50 \mathrm{mM}$ Bis-Tris/ $\mathrm{HCl}$ pH 7,0 e glicerol 15\% (v/v). Inicialmente foi aplicada uma quantidade de amostra suficiente para a visualização das bandas (150 $\mu \mathrm{g}$ de proteínas). Após o preparo do pool dos secretomas, passou-se a utilizar $200 \mu \mathrm{g}$ de proteínas para aumentar o rendimento da segunda dimensão.

Os géis nativos padrão consistiram em gel separador com gradiente de poliacrilamida de $5-18 \%(\mathrm{~m} / \mathrm{v})$ e gel concentrador de poliacrilamida a $4 \%(\mathrm{~m} / \mathrm{v})$, de 1,5 $\mathrm{mm}$ de espessura. Uma versão otimizada, nesse trabalho, do BN-PAGE para a segunda dimensão desnaturante constituiu em um gel separador com gradiente de $10-18 \%(\mathrm{~m} / \mathrm{v})$ e géis separadores a $6 \%$ e $8 \%(\mathrm{~m} / \mathrm{v})$, com por fim um gel concentrador a $4 \%$ de poliacrilamida. Esse procedimento visou reter complexos muito grandes e agregados nos géis separadores $6 \%$ e $8 \%$, dando aos complexos menores maior espaço de resolução no separador $10-18 \%$.

O tampão do gel (6x) continha ácido $\varepsilon$-aminocaproico $3 \mathrm{Me}$ Bis-Tris $0,3 \mathrm{M} / \mathrm{HCl}$ 7,0 . As corridas foram realizadas a $15 \mathrm{~mA}$ por cerca de seis horas, a $4^{\circ} \mathrm{C}$, em um aparato vertical de eletroforese SE 600 (Hoefer, Inc., San Francisco, CA, USA). O tampão anódico utilizado foi Bis-Tris/ $\mathrm{HCl}$ 0,05 M pH 7,0 e o tampão catódico utilizado foi BisTris/HCl 0,015 M pH 7,0 e Coomassie Brilliant Blue G-250 0,2 g.L.-1. Após um terço da corrida, o tampão catódico foi trocado por um tampão catódico com dez vezes menos CBB $\left(0,02\right.$ g.L $\left.\mathrm{L}^{-1}\right)$ para reduzir o background.

Os marcadores moleculares utilizados foram tiroglobulina (669 kDa), ferritina $(440 \mathrm{kDa})$, catalase $(250 \mathrm{kDa})$, lactato desidrogenase $(140 \mathrm{kDa})$ e albumina de soro bovino $(66 \mathrm{kDa})$. Após as eletroforeses, os géis foram corados com solução Coomassie Blue Silver (CANDIANO et al., 2004).

\section{4) Eletroforese bidimensional BN/SDS-PAGE}

A segunda dimensão desnaturante (SDS) da eletroforese nativa (BN) foi realizada após a corrida da primeira dimensão e três horas de incubação do gel em solução Coomassie Blue Silver. Foram realizadas três lavagens de 20 segundos do gel com água Milli-Q (200 mL), seguidas por duas horas de incubação em $200 \mathrm{~mL}$ de solução $0,13 \mathrm{M}$ Tris $\mathrm{pH} 6,8$, SDS $2 \%(\mathrm{~m} / \mathrm{v})$ e $\beta$-mercaptoetanol $1 \%(\mathrm{v} / \mathrm{v})$. Para remover o $\beta$ mercaptoetanol, que é inibidor de polimerização, foram feitas três lavagens de 10 minutos com $200 \mathrm{~mL}$ de $0,13 \mathrm{M}$ Tris pH 6,8 e SDS 0,1\% (m/v).

Fitas correspondentes a cada tipo de secretoma foram então excisadas com auxílio de espaçadores plásticos de gel, para que o corte fosse o mais reto possível, e posicionadas em placas de vidro na posição usual de géis concentradores. $\mathrm{O}$ aparato foi montado para géis com a mesma espessura da primeira dimensão, 1,5 mm. Abaixo de cada fita, foi 
montado um gel desnaturante em gradiente $8-20 \%(\mathrm{~m} / \mathrm{v})$ de poliacrilamida. Em torno da fita do BN-PAGE da primeira dimensão, foi polimerizado um gel concentrador $5 \%(\mathrm{~m} / \mathrm{v})$ de poliacrilamida, com concentrações dobradas dos catalisadores persulfato de amônio e TEMED, devido ao efeito inibidor de polimerização dos resquícios de $\beta$-mercaptoetanol.

A corrida se deu por aproximadamente 16 horas, a $20 \mathrm{~mA} \mathrm{e} 15^{\circ} \mathrm{C}$. Os géis foram corados com solução Coomassie Blue Silver (CANDIANO et al., 2004), mas devido à pouca intensidade dos spots, foram descorados e corados com nitrato de prata (BLUM; BEIER; GROSS, 1987).

\section{5) Digestão de proteínas provenientes de bandas do BN-PAGE}

Vinte e sete bandas candidatas do gel nativo BN-PAGE (sete do pool de secretoma em celulose, sete do pool de secretoma em xilana e treze do pool de secretoma em bagaço de cana) foram cuidadosamente excisadas com auxílio de bisturi, lavadas com água Milli$\mathrm{Q}$ e acondicionadas em microtubos low-binding de 0,6 mL com etanol 50\% (v/v) para a remoção do CBB. As bandas foram selecionadas com base em quatro parâmetros: intensidade da coloração, alta resolução da banda, alta massa molecular e similaridade de migração com bandas de interesse em outros secretomas. Com auxílio de ponteiras plásticas descartáveis, cada banda foi partida em quatro fragmentos menores para aumentar a superfície de contato com os reagentes das etapas subsequentes.

A seguir, foi realizada a digestão em gel dos candidatos a complexos (GHARAHDAGHI et al., 1999; SHEVCHENKO et al., 1996, 2007). Cada banda foi lavada com $50 \mu \mathrm{L}$ de acetonitrila ( $\mathrm{ACN}$ ) e secada em centrífuga a vácuo. A redução das pontes dissulfeto ocorreu por incubação de uma hora a $56^{\circ} \mathrm{C}$ de cada banda em $50 \mu \mathrm{L}$ de solução ditiotreitol (DTT) 10 mM e $\mathrm{NH}_{4} \mathrm{HCO}_{3} 100 \mathrm{mM}$. Após a incubação, a solução redutora foi removida e as cisteínas foram alquiladas em $50 \mu \mathrm{L}$ de solução iodacetamida (IAA) $55 \mathrm{mM}$ e $\mathrm{NH}_{4} \mathrm{HCO}_{3} 100 \mathrm{mM}$ em incubação a $25^{\circ} \mathrm{C}$ por 45 minutos no escuro.

Posteriormente, cada banda passou por quatro lavagens alternadas com $50 \mu \mathrm{L}$ de ACN, $\mathrm{NH}_{4} \mathrm{HCO}_{3} 100 \mathrm{mM}, \mathrm{ACN}$ e $\mathrm{NH}_{4} \mathrm{HCO}_{3} 100 \mathrm{mM}$, nessa ordem. Após a última lavagem, as bandas foram secadas em centrífuga a vácuo e reidratadas por 50 minutos em $50 \mu \mathrm{L}$ de solução gelada de tripsina $12,5 \mathrm{ng} . \mu \mathrm{L}^{-1}, \mathrm{NH}_{4} \mathrm{HCO}_{3} 50 \mathrm{mM}$ e $\mathrm{CaCl}_{2} 5 \mathrm{mM}$. O excesso de solução foi removido e $20 \mu \mathrm{L}$ de solução $\mathrm{NH}_{4} \mathrm{HCO}_{3} 50 \mathrm{mM} \mathrm{e} \mathrm{CaCl}_{2} 5 \mathrm{mM}$ foram adicionados para incubação a $37^{\circ} \mathrm{C}$ overnight.

Os peptídeos trípticos de cada banda foram extraídos por meio da adição de $20 \mu \mathrm{L}$ se ácido acético 5\% (v/v) e sonicação por 20 minutos. O líquido foi coletado, e mais três extrações com ácido acético 5\% (v/v) e ACN 50\% (v/v) foram realizadas com sonicação por 20 minutos. Por fim, os peptídeos trípticos foram secos em centrífuga a vácuo.

\section{6) Dessalinização de peptídeos trípticos extraídos de bandas de BN- PAGE}

A dessalinização dos peptídeos trípticos foi realizada por meio de um protocolo adaptado de StageTips C18 para alta recuperação (RAPPSILBER; MANN; ISHIHAMA, 2007). Microcolunas cromatográficas $\mathrm{C} 18$ foram empacotadas em ponteiras plásticas low-binding de $200 \mu \mathrm{L}$ e encaixadas com adaptadores em microtubos coletores. As 
colunas foram lavadas pela adição de $100 \mu \mathrm{L}$ de metanol com posterior centrifugação a $1000 \mathrm{~g}$ por 3 minutos. Esse passo foi repetido.

Posteriormente, foram realizadas mais duas lavagens com $100 \mu \mathrm{L}$ de solução ACN $80 \%(v / v)$ e ácido acético $0,5 \%$ (v/v) e mais duas lavagens com $100 \mu \mathrm{L}$ de solução ácido acético 0,5\% (v/v), sempre com centrifugação a $1000 \mathrm{~g}$ por 3 minutos para lavar toda a coluna. O conteúdo dos microtubos coletores era descartado a cada lavagem.

Os peptídeos trípticos de cada banda foram ressuspensos em $10 \mu \mathrm{L}$ de ácido trifluoroacético (TFA) $1 \%(\mathrm{v} / \mathrm{v})$ e adicionados nas ponteiras. Por meio de 4 minutos de centrifugação a $900 \mathrm{~g}$, os peptídeos foram aderidos às colunas.

Os sais foram removidos por meio de uma lavagem com $100 \mu \mathrm{L}$ de solução ácido acético $0,5 \%(\mathrm{v} / \mathrm{v})$ com centrifugação a $1000 \mathrm{~g}$ por 3 minutos. Os microtubos coletores foram, então, substituídos por microtubos low-binding para a coleta dos peptídeos. Os peptídeos foram sequencialmente eluídos das colunas por meio de lavagens com $20 \mu \mathrm{L}$ das seguintes soluções: ACN 25\% (v/v) ácido acético 0,5\% (v/v), ACN 50\% (v/v) ácido acético 0,5\% (v/v), ACN 80\% ácido acético 0,5\% (v/v) e ACN 100\% (v/v). Em cada lavagem, foi feita uma centrifugação a $600 \mathrm{~g}$ por 2 minutos. Os eluídos coletados em cada microtubo low-binding foram por fim secos em centrífuga a vácuo.

\section{7) Espectrometria de massa LC-MS/MS}

Os peptídeos provenientes de cada banda foram reconstituídos em $8 \mu \mathrm{L}$ de ácido fórmico $1 \%$ (v/v) para análise no espectrômetro de massas LTQ Orbitrap Elite (Thermo Scientific) acoplado ao sistema de cromatografia líquida UltiMate ${ }^{\circledR} 3000$ Nano LC (Dionex). Os peptídeos foram enriquecidos usando uma coluna trap $(100 \mu \mathrm{m}$ x 3,0 cm) preenchida com resina Reprosil-Pur 120 C18-AQ (tamanho da partícula $5 \mu \mathrm{m}$ - Dr. Maish). Após 10 minutos de lavagem com ácido fórmico 0,1\% (v/v), os peptídeos foram separados em coluna analítica $(100 \mu \mathrm{m} \times 15 \mathrm{~cm})$ preenchida com resina Reprosil-Pur 120 C18-AQ (tamanho da partícula $3 \mu \mathrm{m}$ - Dr. Maish) com fluxo de $230 \mathrm{~nL} . \mathrm{min}^{-1}$.

A separação cromatográfica foi realizada usando eluição com $2 \%$ do solvente $B$ (ACN 95\% (v/v), ácido fórmico 0,1\% (v/v)) durante 10 minutos, seguido por 25 minutos de um gradiente crescente de B 10-35\% e por 10 minutos de B $90 \%$. Os peptídeos foram eluídos da coluna analítica dentro do espectrômetro com ajuda de uma sonda nanospray (Thermo Scientific). A voltagem do spray foi de $3.02 \mathrm{kV}$ e a temperatura de transferência capilar de $70^{\circ} \mathrm{C}$. O LTQ Orbitrap Elite operou no modo Aquisição Dependente de Dados (DDA - Data Dependent Acquisition) usando o programa Xcalibur 2.2 (Thermo Scientific). O ciclo de aquisição consistiu na fragmentação dos 15 íons precursores mais intensos a uma resolução de 120.000 e varredura de massas na região de 300-1650 m/z para geração dos espectros MS/MS usando para a fragmentação do tipo Dissociação por Alta Energia de Colisão (HCD - Higher-energy Collisional Dissociation). Os íons selecionados para fragmentação foram dinamicamente excluídos durante 90 segundos.

A interpretação dos dados de espectrometria foi realizada no programa PEAKS Studio, programado para análises com tripsina do tipo Orbitrap/Orbitrap com fragmentação HCD e refinamento de dados default. Os parâmetros tolerados de erro foram $10 \mathrm{ppm}$ da massa do precursor usando massa monoisotópica e 0,05 Da da massa dos fragmentos, com permissão para até uma clivagem não-específica e máximo de duas clivagens perdidas. Foram considerados dados com False Discovery Rate $<1 \%$ com ao 
menos um peptídeo único. Como modificações pós-traducionais, foram permitidas carbamidometilação de cisteínas (fixa), oxidação de metioninas (variável) e deaminação de asparagina e glutamina (variável). O máximo de modificações pós-traducionais permitido por peptídeo foi de cinco PTMs. O banco de dados utilizado foi o de genoma do UniProt Knowledgebase, UniProtKB (http://www.uniprot.org/) para T. harzianum. Os parâmetros de busca estão sumarizados na Tabela 1 .

As proteínas identificadas como não-caracterizadas foram analisadas por Basic Local Alignment Search Tool (BLAST) no banco de dados total do UniProtKB para procurar proteínas conhecidas com alta identidade, permitindo a discussão dos resultados.

Tabela 1. Parâmetros de buscas para os dados de espectrometria de massa LC-MS/MS.

\begin{tabular}{|c|c|}
\hline Nome do programa de busca & PEAKS Studio 7,0 \\
\hline Tolerância de erro de massa parental & $10,0 \mathrm{ppm}$ \\
\hline Tolerância de erro de massa de fragmento & $0,05 \mathrm{Da}$ \\
\hline Tipo de busca da massa do precursor & Monoisotópica \\
\hline Enzima & Tripsina \\
\hline Máximo de clivagens perdidas & 2 \\
\hline Máximo de clivagens não-específicas & 1 \\
\hline PTM fixa & Carbamidometilação (C) \\
\hline PTMs variáveis & Oxidação (M) e Deamidação (NQ) \\
\hline Máximo de PTMs variáveis por peptídeo & 5 \\
\hline Banco de dados & Trichoderma harzianum (UniProtKB) \\
\hline
\end{tabular}

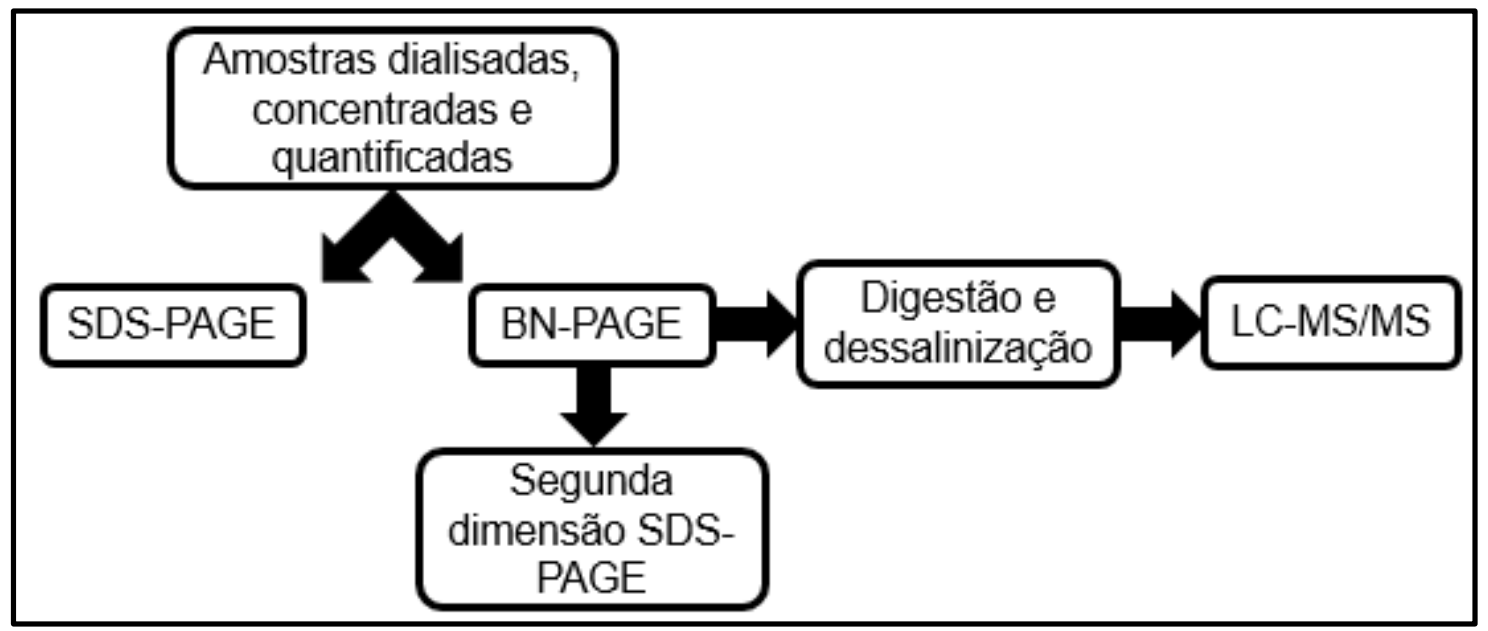

Figura 13. Fluxograma da metodologia de eletroforeses e espectrometria de massa para análise do secretoma de T. harzianum. 


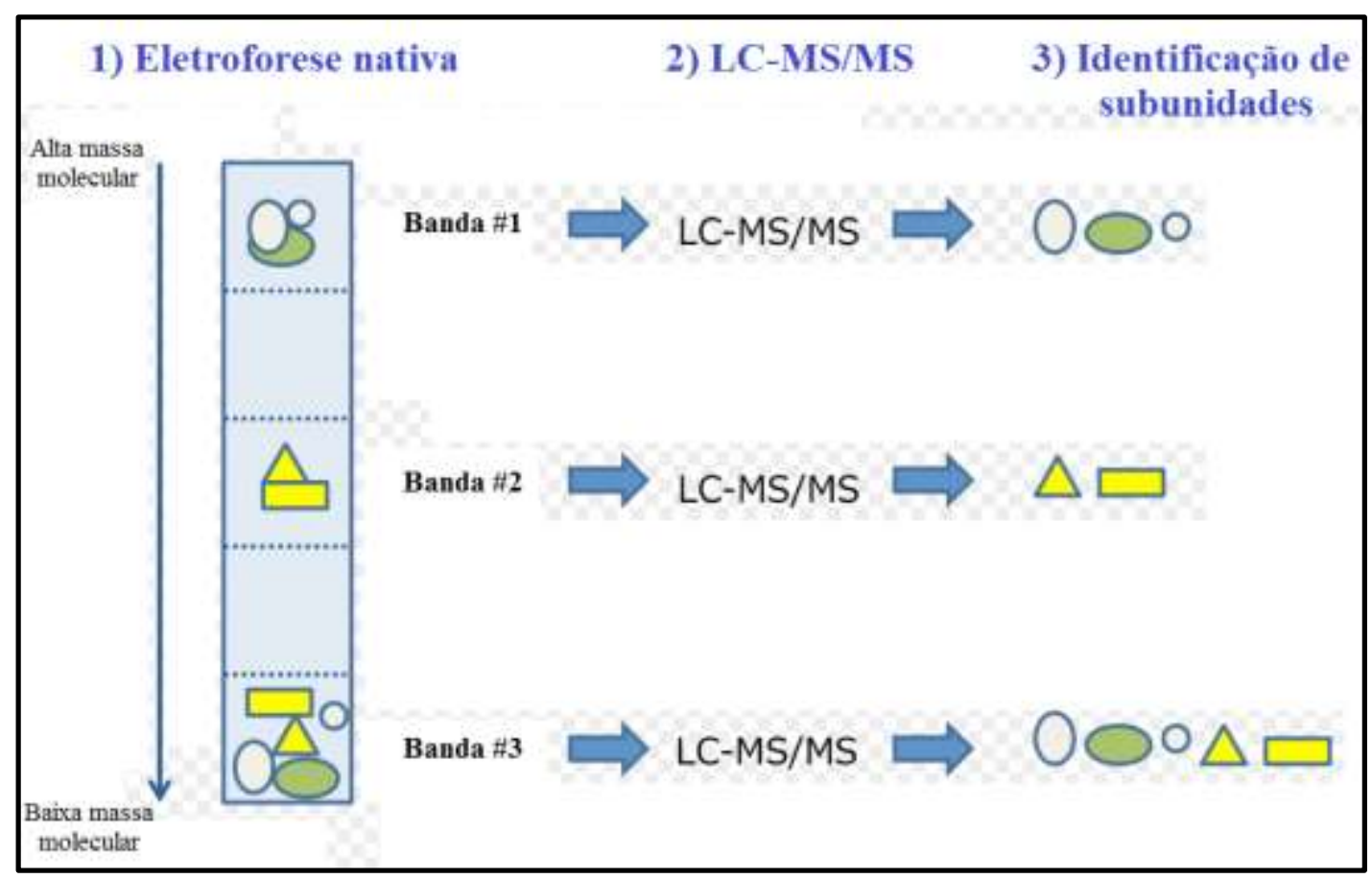

Figura 14. Diagrama da estratégia utilizada para a identificação das proteínas por LCMS/MS de bandas excisadas dos géis nativos. <Adaptado do PCoM-DB (http://pcomdb.lowtem.hokudai.ac.jp), Protein Co-Migration Database for Photosynthetic Organisms. Acesso em 11/02/2017>.

\section{5) Resultados e Discussão}

\section{1) Cultivo e separações eletroforéticas}

Após a diálise e a liofilização dos secretomas, foi realizada a quantificação das proteínas presentes em cada amostra para que quantidades definidas e apropriadas de proteína pudessem ser utilizadas em experimentos subsequentes. Com base nos resultados das quantificações das amostras concentradas foi possível estimar a concentração proteica original dos secretomas, apresentada abaixo na Tabela 2.

Tabela 2. Concentração proteica de cultivo dos secretomas de T. harzianum para três meios de cultivo realizados em triplicata, determinada por Qubit ${ }^{\mathrm{TM}}$ Protein Assay Kit.

\begin{tabular}{|c|c|}
\hline Fonte de carbono do secretoma & Concentração (média \pm desvio padrão) \\
\hline Xilana oat spelts & $42,8 \pm 2,2 \mu \mathrm{g} / \mathrm{mL}$ \\
\hline Celulose microcristalina & $46,6 \pm 1,7 \mu \mathrm{g} / \mathrm{mL}$ \\
\hline Bagaço de cana & $39,8 \pm 4,0 \mu \mathrm{g} / \mathrm{mL}$ \\
\hline
\end{tabular}

Os perfis eletroforéticos das amostras de secretoma, em SDS-PAGE (Figura 15) e BN-PAGE (Figura 16), foram visivelmente diferentes entre si, enquanto as replicatas biológicas mostraram perfis com alta reprodutibilidade. No entanto, apesar da presença de bandas exclusivas para cada secretoma, também se notou a presença de bandas coincidentes com intensidades semelhantes e distintas, sugerindo variações na abundância de algumas proteínas a depender da fonte de carbono (e não somente presença/ausência). 
As diferenças entre os secretomas deveram-se às diferenças de indução nos genes do fungo em resposta à diversidade estrutural dos substratos, como já descrito. Com base nesses resultados, conforme descrito na metodologia, começou-se a trabalhar com um pool de cada amostra $\left(\mathrm{X}=\bar{X}_{1-3} ; \mathrm{C}=\bar{C}_{1-3} ; \mathrm{B}=\bar{B}_{1-3}\right)$.

Quando o fungo foi exposto a diferentes polímeros lignocelulósicos, diversas proteínas foram expressas, inclusive de alta massa molecular (possíveis complexos proteicos) (Figura 16). Em BN-PAGE o marcador não é muito confiável para a estimativa das massas das proteínas e complexos proteicos, devido aos seus diferentes formatos nativos, tamanhos e quantidades de regiões hidrofóbicas expostas, que facilitam ou atrapalham a migração no gel e aumentam ou diminuem a quantidade de moléculas de CBB que dão a carga negativa para induzir a migração.

Estudos anteriores demonstraram variações da ordem de $\pm 20 \%$ na massa de proteínas utilizando uma curva de calibração baseada no marcador (SCHÄGGER; CRAMER; VON JAGOW, 1994). Contudo, ainda que as estimativas sejam pouco precisas quando se compara as bandas das amostras com as bandas dos marcadores, observou-se a presença de bandas de alta massa molecular a ser estudadas como candidatas para a detecção de possíveis complexos proteicos.

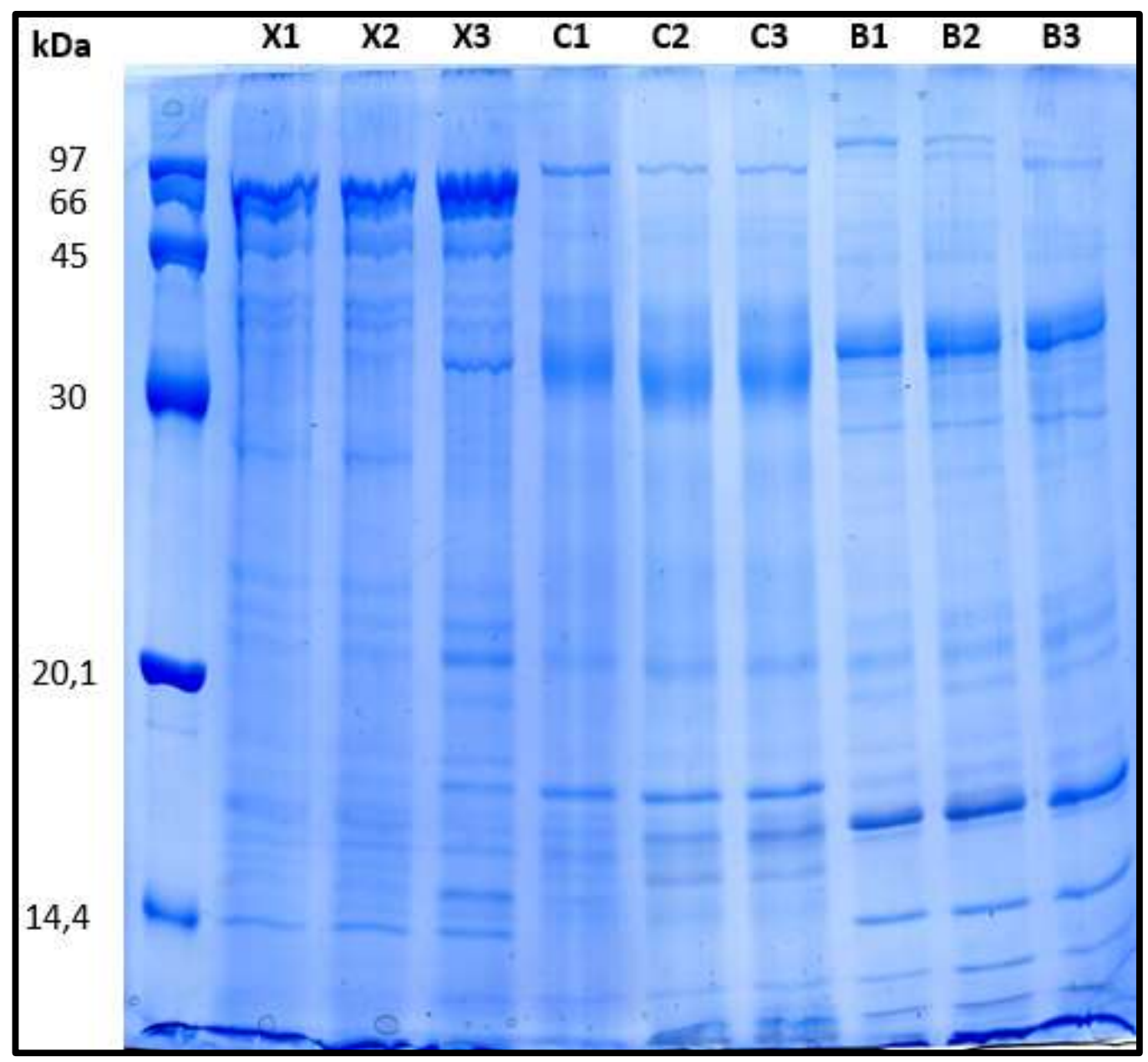

Figura 15. SDS-PAGE $12 \%(\mathrm{~m} / \mathrm{v})$ dos secretomas de $T$. harzianum cultivado em xilana oat spelts (X), celulose microcristalina (C) ou bagaço de cana (B), com aplicação de 40 $\mu \mathrm{g}$ de proteínas por poço. Os números indicam replicatas biológicas. Gel corado com Coomassie Blue Silver. 


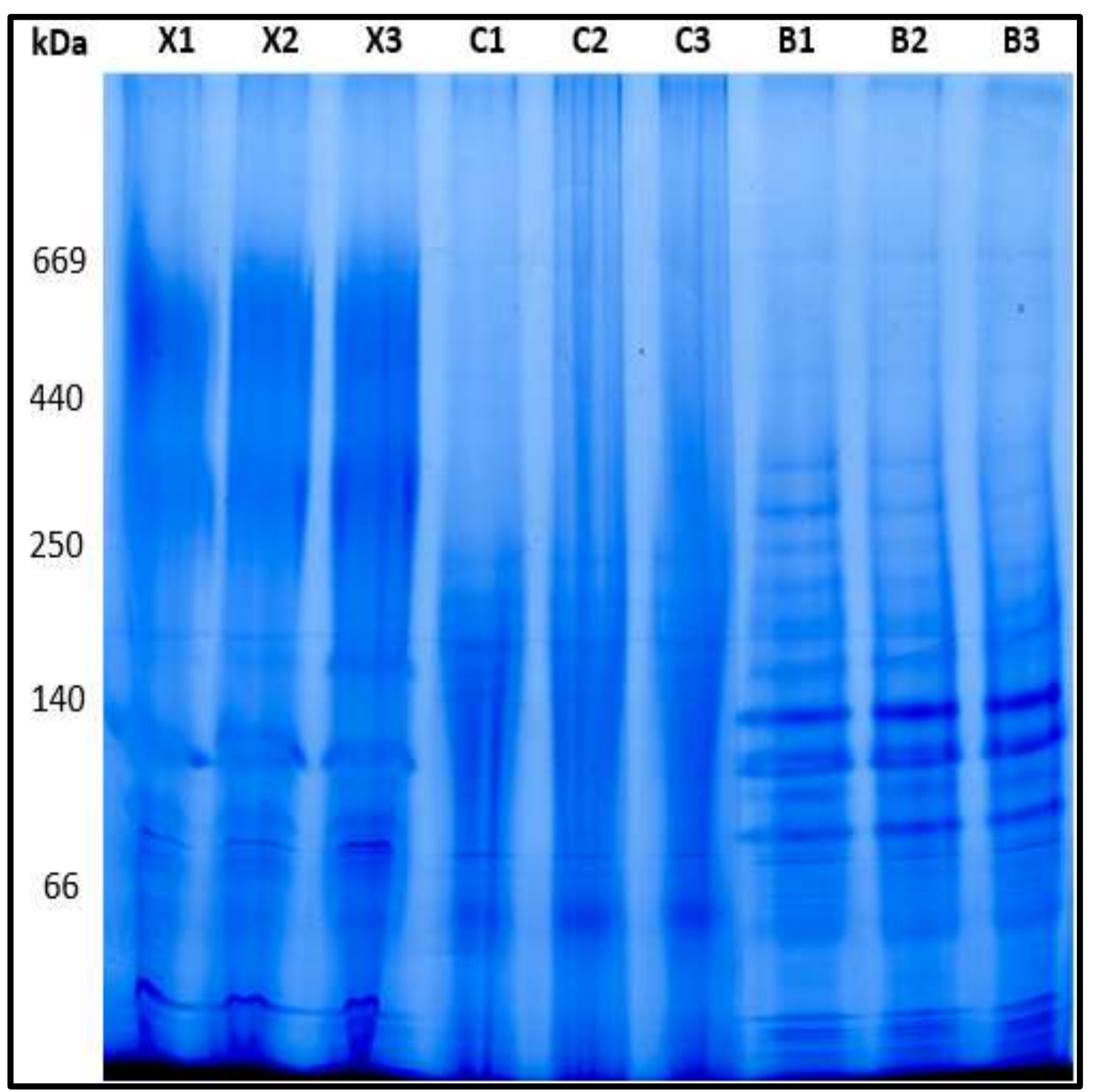

Figura 16. BN-PAGE 5-18\% (m/v) dos secretomas de T. harzianum cultivado em xilana oat spelts (X), celulose microcristalina (C) ou bagaço de cana (B), com aplicação de 150 $\mu \mathrm{g}$ de proteínas por poço. Os números indicam replicatas biológicas. Gel corado com Coomassie Blue Silver.

Outra informação relevante, quanto à técnica, é que o CBB previne a agregação das proteínas devido à repulsão eletrostática e, portanto, não há efeito da concentração de proteínas no perfil eletroforético do gel. Os complexos observados são preservados como se encontravam na amostra antes da adição do CBB, embora seja possível que o aumento da concentração da amostra durante a liofilização favoreça a formação de algum complexo por deslocamento de equilíbrio (DA SILVA et al., 2012; SCHÄGGER; CRAMER; VON JAGOW, 1994).

Um novo gel BN-PAGE foi realizado, contendo o pool de proteínas, e com a carga de proteínas aumentada para $200 \mu \mathrm{g}$ (Figura 17). Esse gel permitiu a visualização com um pouco mais de clareza das bandas, devido à maior carga proteica, e a partir dele foram escolhidas bandas de interesse para as análises de espectrometria de massa. 


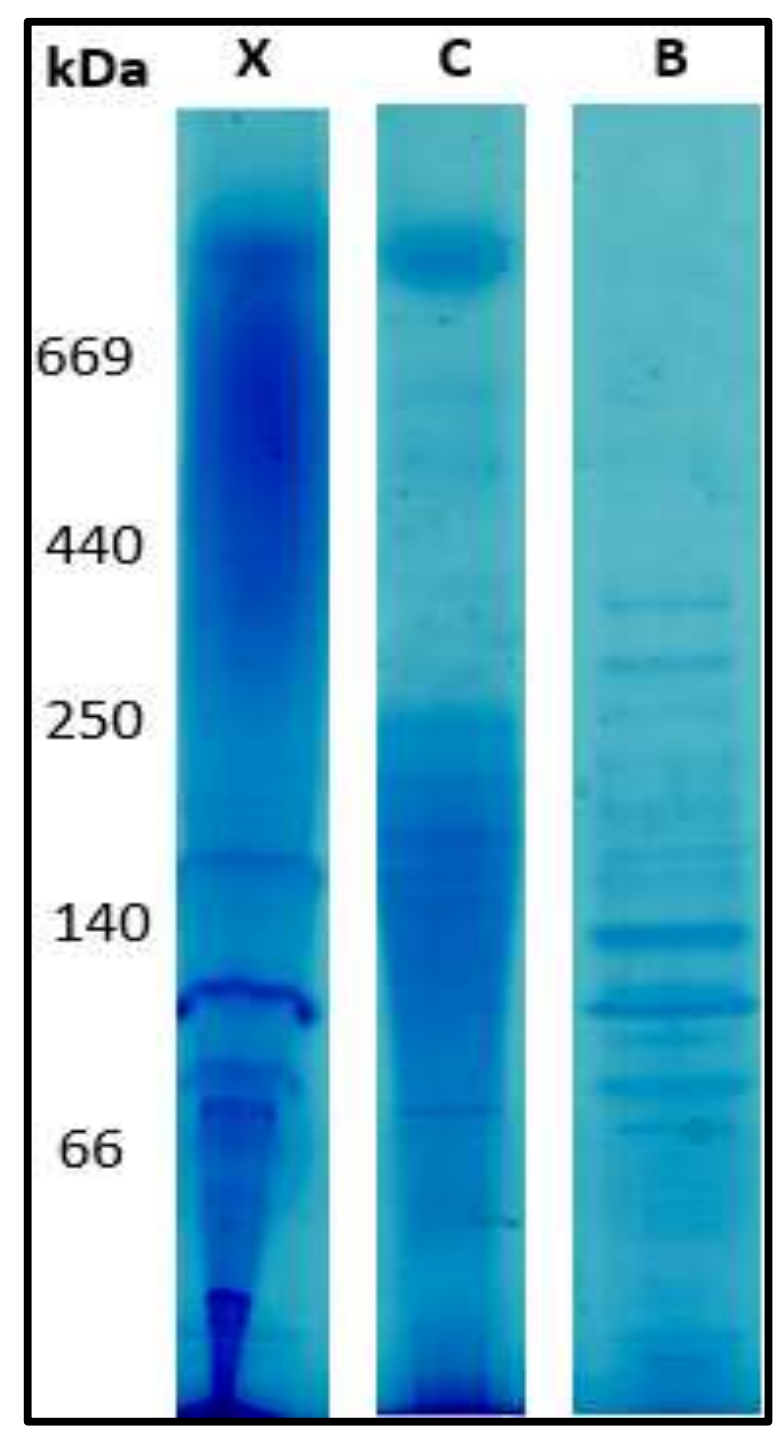

Figura 17. BN-PAGE 5-18\% (m/v) dos pools dos secretomas de T. harzianum cultivado em xilana oat spelts (X), celulose microcristalina (C) ou bagaço de cana (B), com aplicação de $200 \mu \mathrm{g}$ de proteínas por poço. Gel corado com Coomassie Blue Silver.

Uma preocupação manifestada em discussões do grupo de pesquisa no desenho da metodologia de cultivo foi com relação à adição de glicose nos meios líquidos de cultivo, uma vez que ela é um conhecido repressor da expressão de genes de enzimas hidrolíticas (ARO; PAKULA; PENTTILÄ, 2005). A adição foi feita porque não se estava observando crescimento expressivo de micélio nos 9 dias de cultivo, tempo escolhido por ter sido utilizado em trabalhos anteriores do grupo de pesquisa com bagaço de cana por representar o pico de atividade enzimática nessa fonte de carbono (DA SILVA et al., 2012; GÓMEZ-MENDOZA et al., 2014).

Um ponto importante a ser ressaltado é que o presente trabalho é ainda inicial e exploratório da capacidade genética que o fungo possui para a produção de complexos multienzimáticos. Caso haja potencial para a produção de complexos de interesse, ele poderá ser explorado para aplicações industriais através de trabalhos subsequentes que visem descobrir condições ótimas de cultivo para a produção deste ou daquele complexo. Esses estudos levarão em conta não só a composição precisa das fontes de carbono e o tempo de cultivo, mas também variáveis como $\mathrm{pH}$, aeração, concentração de esporos do 
inóculo, etc. Não é objetivo do presente trabalho encontrar essas condições ótimas para produção de complexos.

Além disso, a adição da glicose, apesar de inicialmente gerar repressão na expressão gênica, já não era mais um fator determinante para a composição do secretoma ao fim dos 9 dias de cultivo, como pode ser visto nas grandes diferenças entre os perfis eletroforéticos em SDS-PAGE e BN-PAGE. As diferenças entre os secretomas podem, portanto, ser explicadas pelas diferenças nos polissacarídeos presentes em cada tipo de cultivo.

De qualquer modo, seria inevitável a presença de glicose nos meios, uma vez que ela é produto da degradação da celulose (presente nos meios com celulose e bagaço de cana) e que ela se encontra presente no meio com xilana por ser um subproduto do processo de produção da xilana, no qual a biomassa é tratada com celulases (o rótulo das xilanas comerciais acusa percentuais de contaminação com glicose).

A detecção de bandas de alta massa molecular em géis BN-PAGE por si só não é suficiente para garantir que se tratem de complexos proteicos. Uma maneira de confirmar a presença de complexos nas amostras é o acoplamento de uma segunda dimensão desnaturante à primeira dimensão nativa.

Como, tanto no SDS-PAGE quanto no BN-PAGE tradicionais, a separação eletroforética ocorre levando em consideração a massa molecular das proteínas, uma proteína monomérica (que não faz parte de um complexo) migra de maneira semelhante em ambos os tipos de gel. Já uma proteína que se encontra complexada migra menos no BN-PAGE que no SDS-PAGE, pois está presa a várias outras proteínas e sujeita a uma massa molecular maior do complexo como um todo.

Quando se realiza uma eletroforese bidimensional na qual o critério de separação é o mesmo em ambas as dimensões (no caso, a massa molecular), proteínas isoladas formam uma linha diagonal no gel da segunda dimensão (Figura 18).

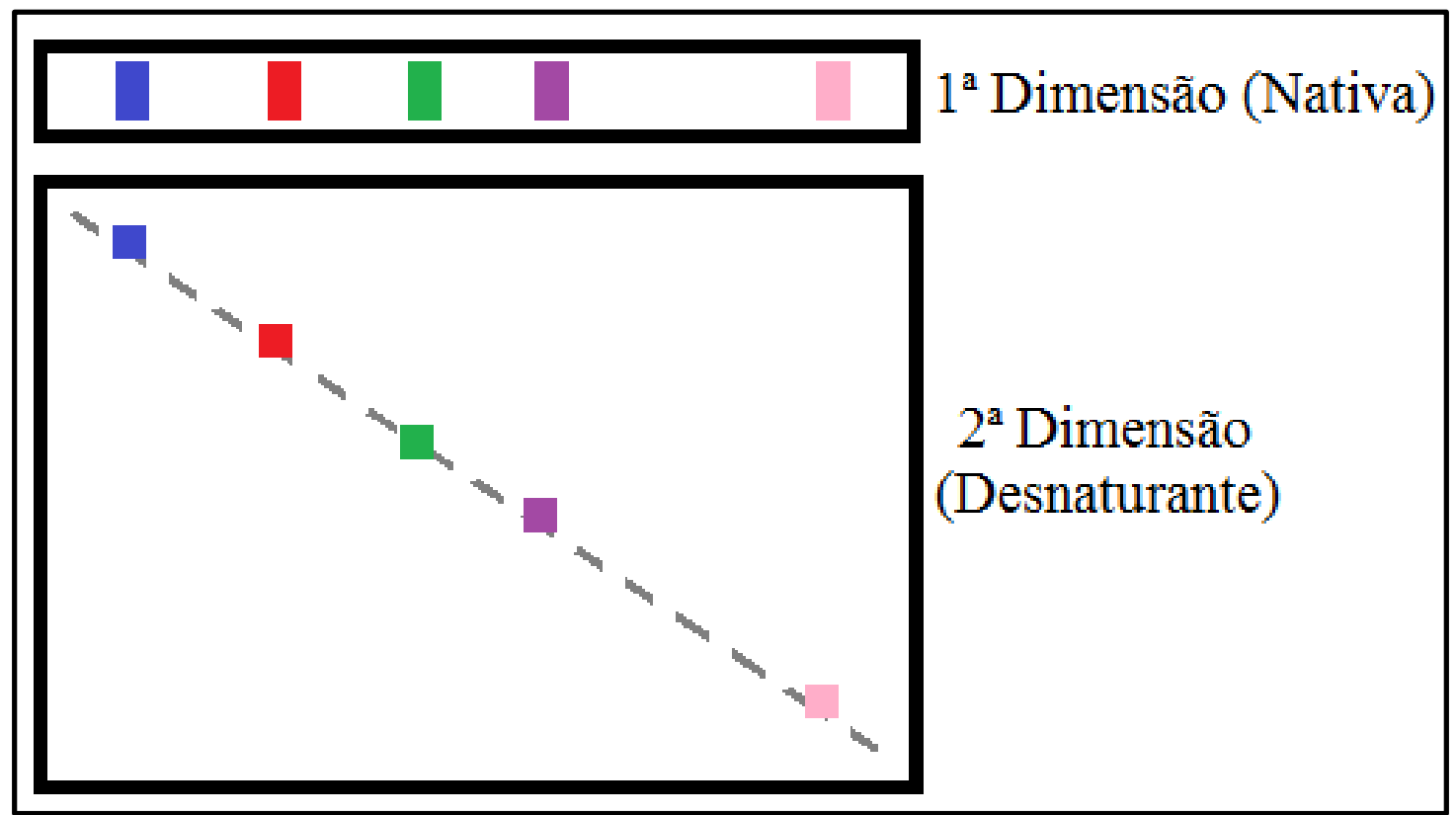

Figura 18. Representação esquemática de um perfil de eletroforese bidimensional BN/SDS-PAGE no qual não há nenhuma proteína complexada na amostra inicial. As proteínas migram na segunda dimensão proporcionalmente a quanto migraram na primeira dimensão, formando uma linha diagonal aproximada. 
Já quando há a presença de complexos multienzimáticos na amostra, ainda que o critério de separação eletroforética nas duas dimensões seja o mesmo (a massa molecular), ocorre um fenômeno na transição entre a primeira e a segunda dimensão: os complexos são desfeitos na desnaturação proteica, e as subunidades do complexo podem migrar livremente (Figura 19). É possível que proteínas horizontalmente alinhadas sejam as mesmas subunidades em complexos diferentes, pois migraram de forma semelhante na segunda dimensão.

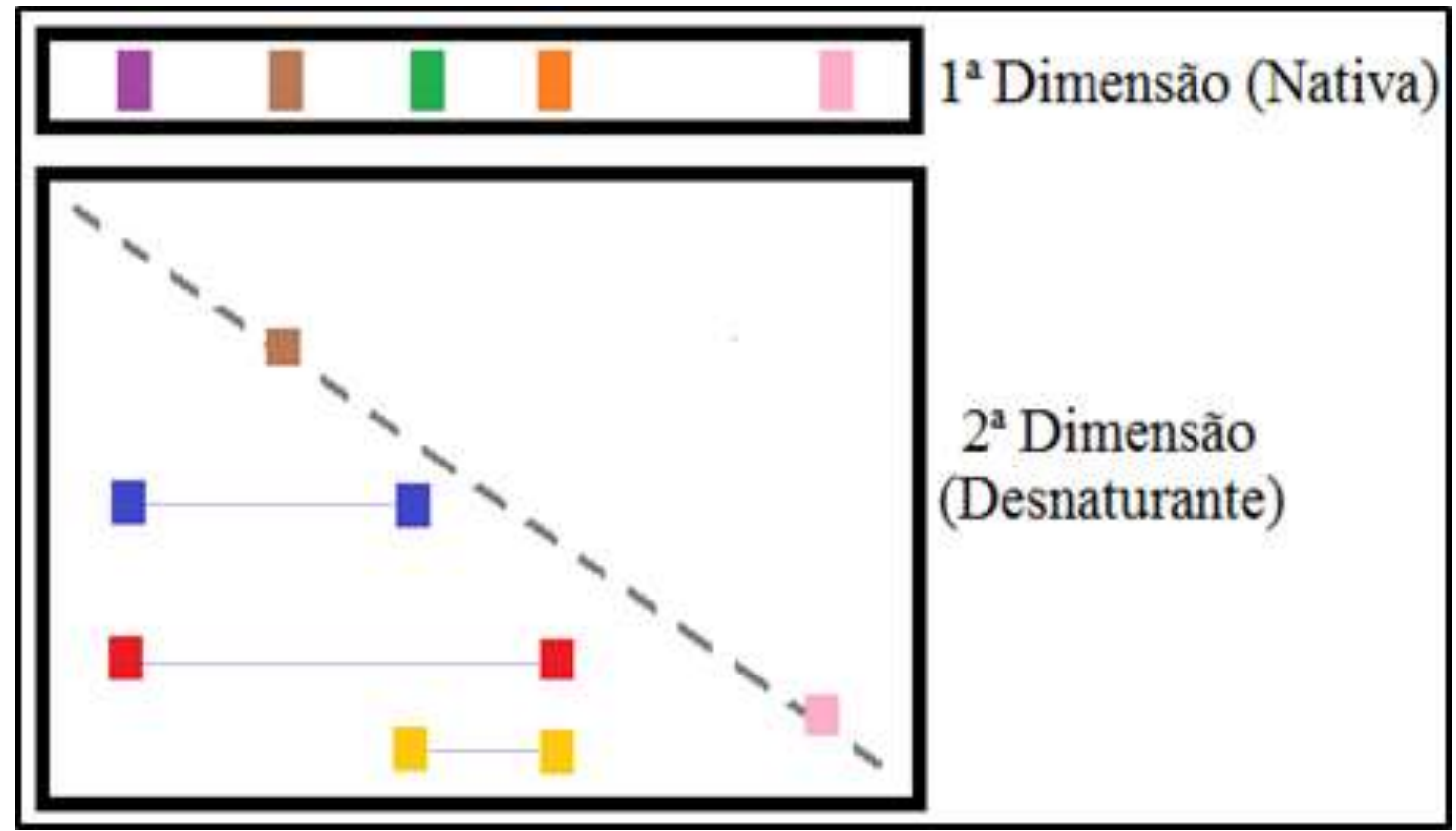

Figura 19. Representação esquemática de um perfil de eletroforese bidimensional BN/SDS-PAGE no qual há três complexos proteicos na amostra inicial (em roxo, verde e laranja). Livres umas das outras na segunda dimensão, as subunidades migram diferencialmente e se destacam da linha diagonal. $\mathrm{O}$ alinhamento horizontal das subunidades idênticas está indicado na linha lilás.

Além da fita do gel nativo com gradiente de 5-18\% (representado na Figura 17), também foi submetida à segunda dimensão uma fita de cada amostra corrida num gel nativo com gradiente de 10-18\% (Figura 20), com separadores de 6\% e $8 \%$ e concentrador de $4 \%$. O objetivo desse gel foi garantir uma melhor resolução dos complexos proteicos e proteínas de massa abaixo de $440 \mathrm{kDa}$, permitindo maior espaço de migração e segurando moléculas maiores ou agregados nos géis concentradores de malhas mais frouxas acima. 


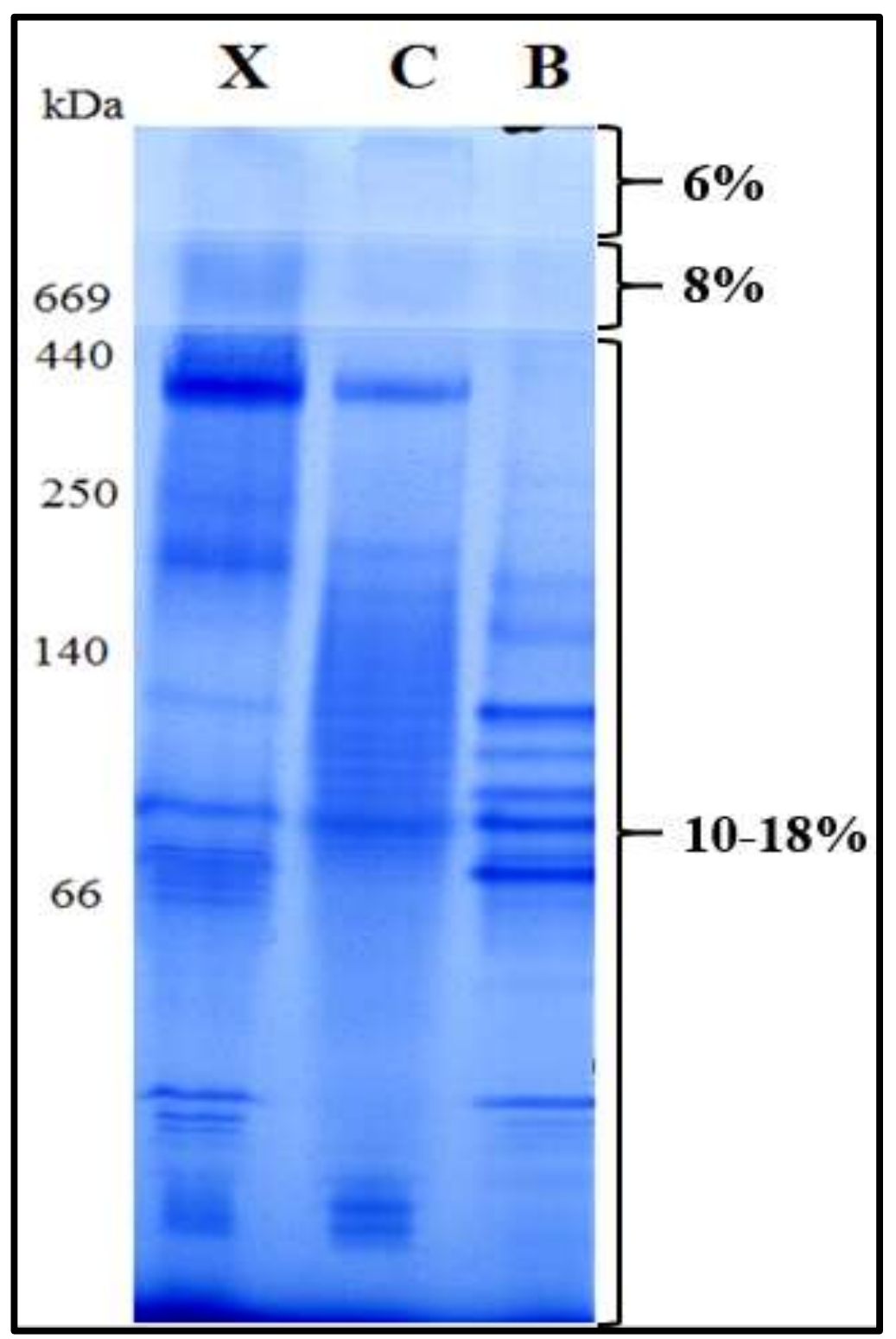

Figura 20. BN-PAGE 10\%-18\% (m/v) dos pools dos secretomas de T. harzianum cultivado em xilana oat spelts $(\mathrm{X})$, celulose microcristalina $(\mathrm{C})$ ou bagaço de cana (B), com aplicação de $200 \mu \mathrm{g}$ de proteínas por poço. Gel corado com Coomassie Blue Silver.

Os resultados para eletroforese bidimensional BN/SDS-PAGE do secretoma de $T$. harzianum cultivado em bagaço de cana estão mostrados na Figura 21 para primeira dimensão com 5-18\% de gradiente de poliacrilamida e na Figura 22 para primeira dimensão com 10-18\% de gradiente de poliacrilamida. Comparando um gel com o outro, é possível ver que no gel 10-18\% a resolução geral foi maior, permitindo que as proteínas ficassem mais distribuídas ao longo do gel e evidenciando melhor as proteínas de menor massa. Inclusive, é possível na Figura 22 ver à direita uma linha diagonal um pouco distorcida (destacada em vermelho) para proteínas que migraram sozinhas ou em complexos com poucas proteínas de massa semelhante. 


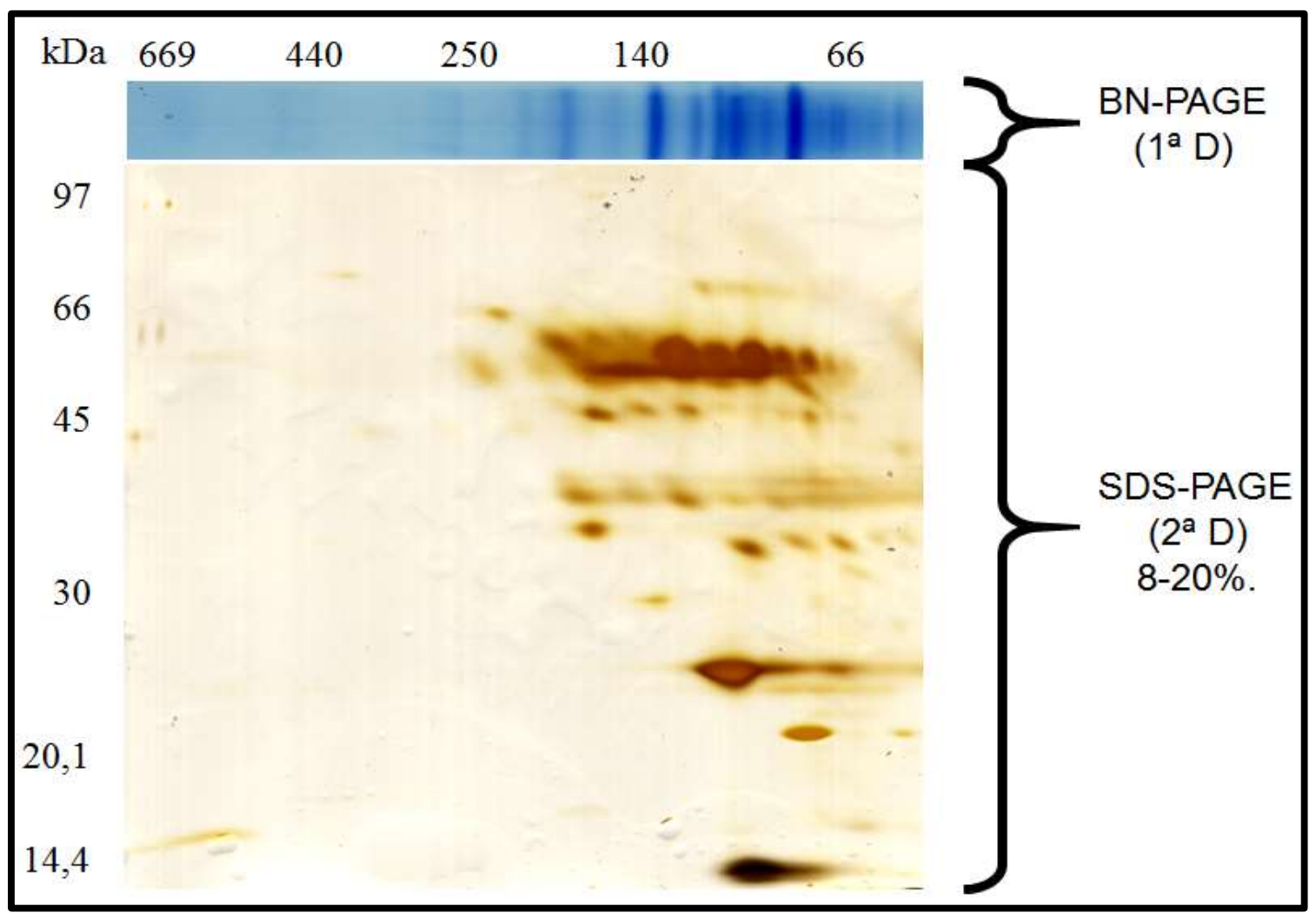

Figura 21. Eletroforese bidimensional BN/SDS-PAGE do secretoma cultivado em bagaço de cana, com primeira dimensão em gradiente de poliacrilamida de 5-18\% e segunda dimensão com gradiente de poliacrilamida de $8-20 \%$. Gel corado com nitrato de prata.

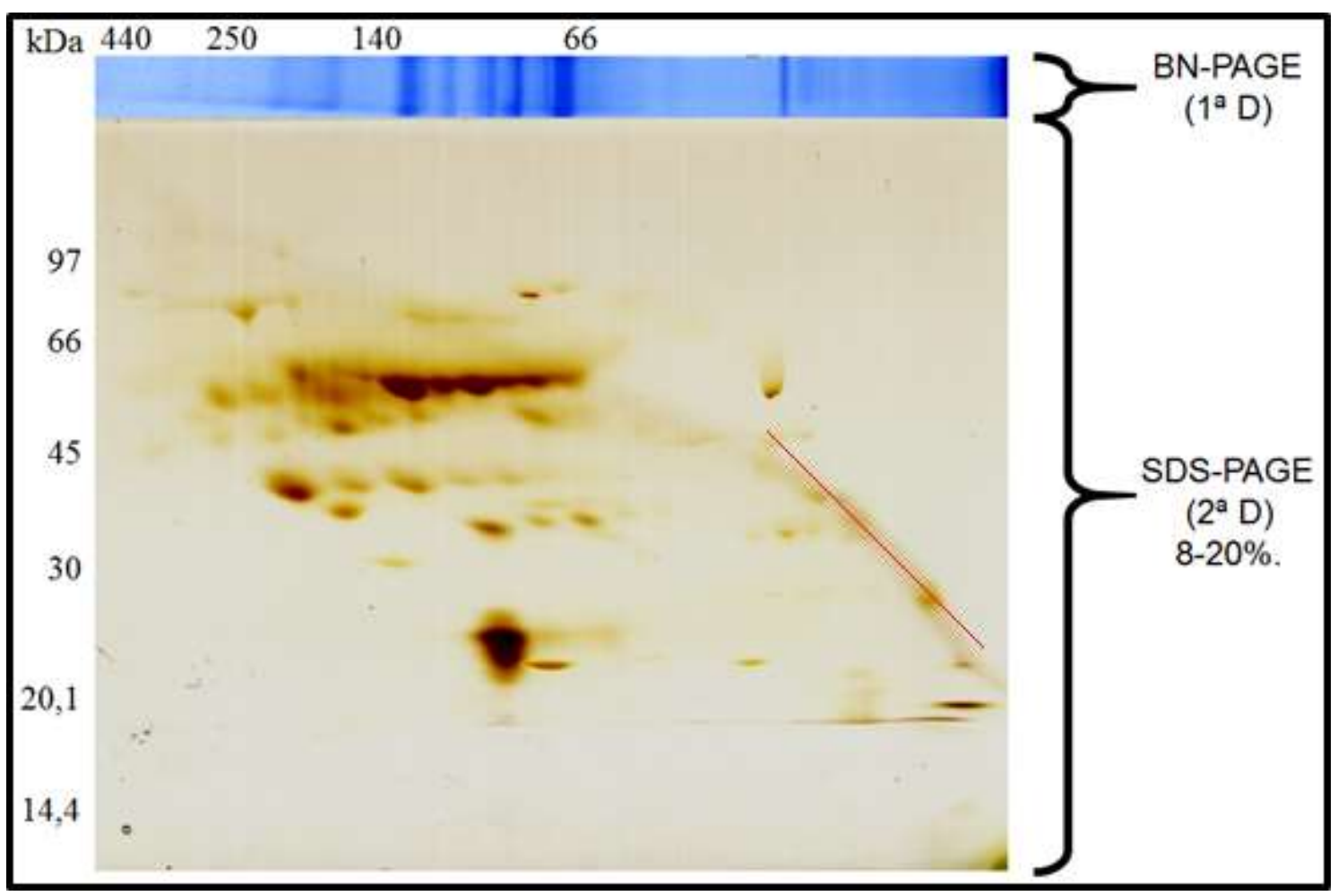

Figura 22. Eletroforese bidimensional BN/SDS-PAGE do secretoma cultivado em bagaço de cana, com primeira dimensão em gradiente de poliacrilamida de 10-18\% e segunda dimensão com gradiente de poliacrilamida de 8-20\%. Linha diagonal aproximada destacada em vermelho. Gel corado com nitrato de prata. 
Nos demais perfis bidimensionais, no entanto, não se percebe nada sequer próximo de uma linha diagonal: a maior parte das bandas da primeira dimensão se decompôs em várias proteínas. Esse resultado demonstra uma elevada tendência à formação de complexos no secretoma do fungo nessas condições, sendo uma regra e não uma exceção. É importante ressaltar, no entanto, que o fato de o complexo estar presente não indica, necessariamente, que ele é funcional.

Contudo, um trabalho anterior com secretoma de T. harzianum cultivado em bagaço de cana como fonte de carbono mostrou, através de zimogramas unidimensional e bidimensional nativos no qual o gel foi copolimerizado com celulose e com xilana, ampla atividade celulolítica e xilanolítica após coloração com Congo Red (um corante para carboidratos que mostra halos onde as enzimas hidrolisaram os carboidratos presentes na região) (DA SILVA et al., 2012).

O presente trabalho foi capaz de demonstrar uma grande diversidade de complexos proteicos no secretoma de T. harzianum crescido em bagaço de cana os quais, à luz dos resultados dos zimogramas mostrados por da Silva e colaboradores em 2012, em grande parte possuem atividade celulolítica e xilanolítica. Nesse trabalho anterior, só foram estudadas três bandas do gel nativo e não foi realizada a decomposição de todos os complexos por eletroforese bidimensional, aqui realizada.

Outro ponto que chama a atenção nos géis bidimensionais é a grande quantidade de proteínas alinhadas horizontalmente, o que pode sugerir que se trate de uma mesma cadeia polipeptídica (subunidade) presente em diferentes complexos (embora apenas uma identificação individual de cada spot possa confirmar a hipótese). Em algumas das linhas é possível observar um gradiente decrescente de intensidade do spot da esquerda para a direita, ou seja, de complexos maiores para complexos menores. Caso seja a mesma subunidade, isso pode sugerir uma variação de sua estequiometria ao longo de complexos, ou seja, vários desses complexos podem, na verdade, ser variações de estágios de complexação de um mesmo complexo.

É, ainda, possível que vários dos complexos tenham a mesma composição proteica, mas diferentes níveis de glicosilação, o que faz com que migrem até diferentes pontos na primeira dimensão (as diferenças de massa todas, somadas, geram uma diferença global grande o bastante para gerar outra banda no gel). Há, por fim, proteínas que parecem fazer parte de vários complexos distintos. Não é descrito para complexos fúngicos uma proteína âncora como é o caso da escafoldina em celulossomas bacterianos, mas esses resultados sugerem a possibilidade de haver uma ou mais proteínas que $\operatorname{possa}(m)$ atuar na organização dos complexos.

A identificação das subunidades desses géis, provavelmente por MALDITOF/TOF, será futuramente realizada como continuação desse trabalho para que essas hipóteses apresentadas possam ser confirmadas ou refutadas. Outra possibilidade interessante para trabalhos futuros é a deglicosilação química ou enzimática dos secretomas antes da eletroforese bidimensional, a qual pode reduzir a complexidade dos perfis eletroforéticos. Um risco, no entanto, é que a deglicosilação desfaça os complexos proteicos devido à modificação estrutural proteica resultante do processo (MOREMEN; TIEMEYER; NAIRN, 2012).

Os resultados para eletroforese bidimensional do secretoma de T. harzianum cultivado em celulose microcristalina estão mostrados na Figura 23 para primeira dimensão com 5-18\% de gradiente de poliacrilamida e na Figura 24 para primeira dimensão com 10-18\% de gradiente de poliacrilamida. O secretoma também se mostrou 
rico em complexos proteicos, com muitos alinhamentos horizontais (possíveis mesmas subunidades presentes em diferentes complexos). Uma região com diversas bandas bem definidas e muito próximas umas das outras, no BN-PAGE, gerou os spots de maior intensidade na segunda dimensão. Embora à primeira vista possa parecer um borrão único, cada spot (por algum motivo desconhecido, em formato oblíquo diagonal) está separado do seguinte. Novamente, podem ser variações de estequiometria ou de padrões de glicosilação, e a identificação dos spots por MALDI-TOF/TOF futuramente pode ajudar a elucidar essas questões determinando quantas subunidades diferentes existem.

Os resultados para eletroforese bidimensional do secretoma de $T$. harzianum cultivado em xilana oat spelts estão mostrados na Figura 25 para primeira dimensão com $5-18 \%$ de gradiente de poliacrilamida e na Figura 26 para primeira dimensão com 10$18 \%$ de gradiente de poliacrilamida. Nesse caso, a resolução do gel com gradiente 10$18 \%$ ficou menor, com a maioria dos spots na metade esquerda do gel e pouco resolvidos. Também se observou a decomposição de bandas e distribuição de spots fora da linha diagonal, com muitos alinhamentos horizontais.

Enfim, os conjuntos de géis dos três secretomas demonstram a presença de complexos em todas as condições testadas, com perfis eletroforéticos bastante distintos mostrando uma resposta bem variada do fungo a cada fonte de carbono. Não só há variação na produção de proteínas, como relatado anteriormente (GÓMEZ-MENDOZA et al., 2014), mas nos padrões de interação proteica observados, o que demonstra uma maior complexidade na capacidade de resposta e adaptação do fungo às diferentes situações.

Para os secretomas cultivados em celulose microcristalina e xilana oat spelts, não há zimogramas para inferências visuais das atividades celulolítica e xilanolítica devido a dificuldades na execução do protocolo feito para bagaço de cana (DA SILVA et al., 2012). A execução do protocolo tal como descrito no artigo não foi reprodutível apesar de várias tentativas (dados não mostrados). 


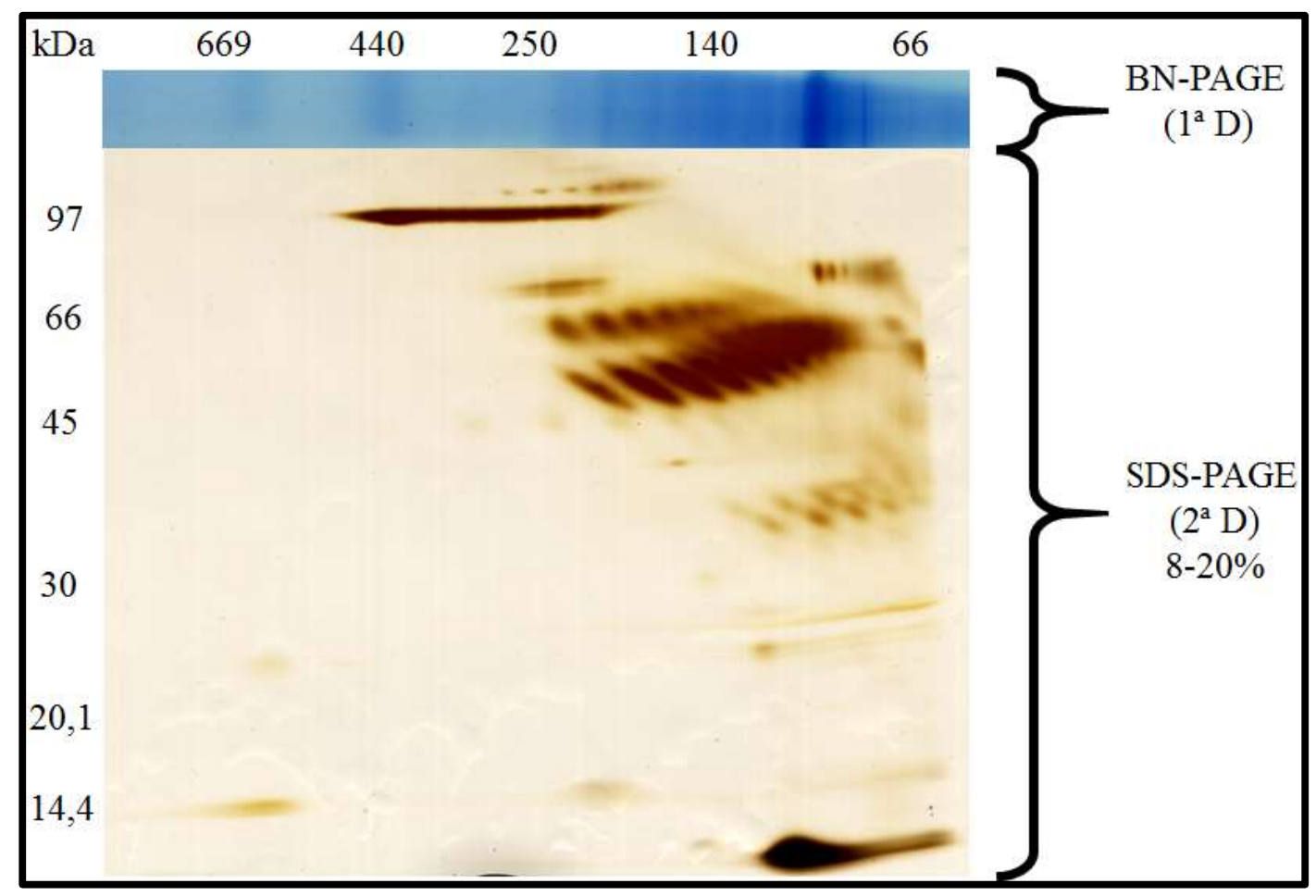

Figura 23. Eletroforese bidimensional BN/SDS-PAGE do secretoma cultivado em celulose microcristalina, com primeira dimensão em gradiente de poliacrilamida de 5$18 \%$ e segunda dimensão com gradiente de poliacrilamida de $8-20 \%$. Gel corado com nitrato de prata.

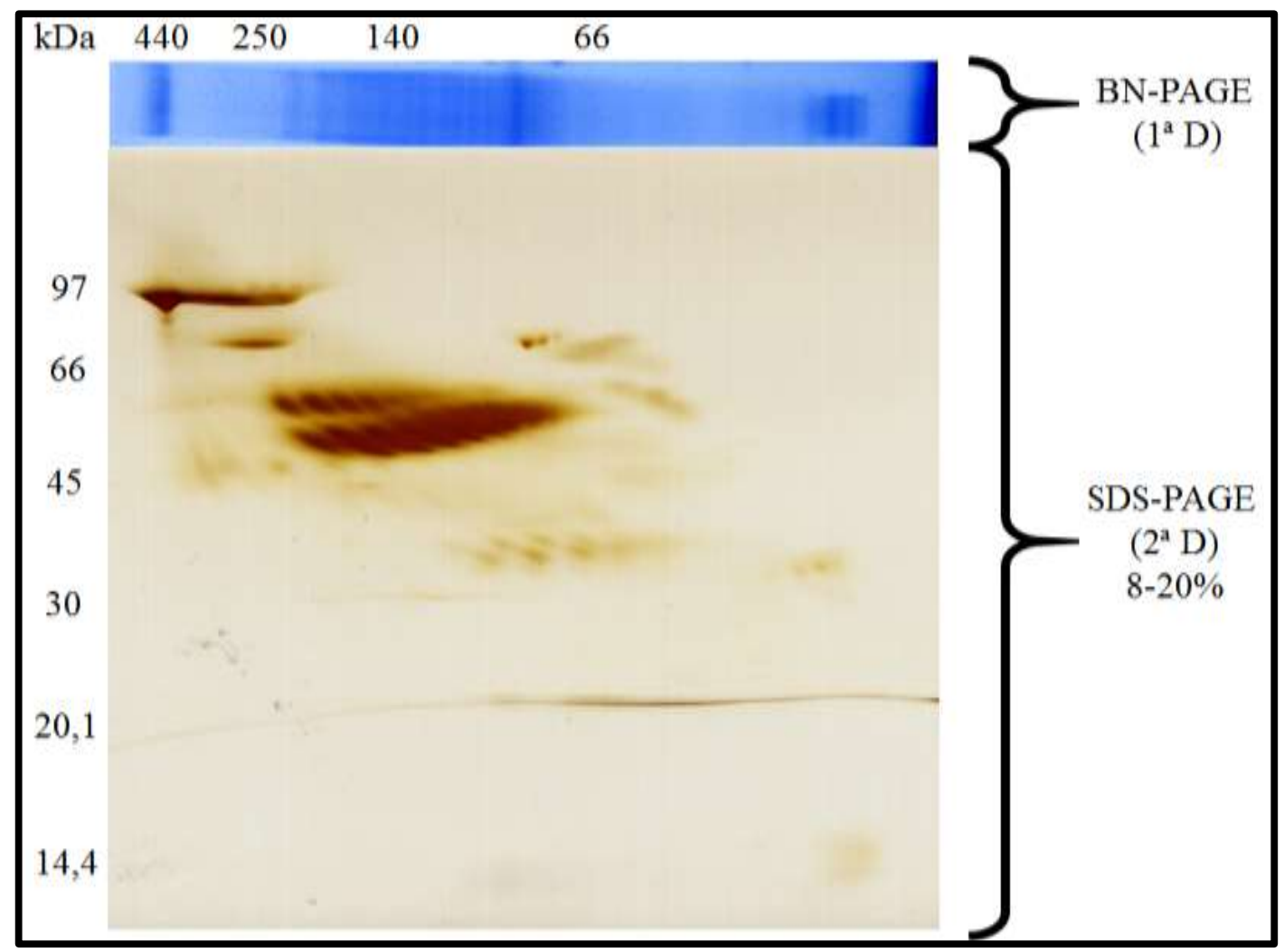

Figura 24. Eletroforese bidimensional BN/SDS-PAGE do secretoma cultivado em celulose microcristalina, com primeira dimensão em gradiente de poliacrilamida de 10$18 \%$ e segunda dimensão com gradiente de poliacrilamida de $8-20 \%$. Gel corado com nitrato de prata. 


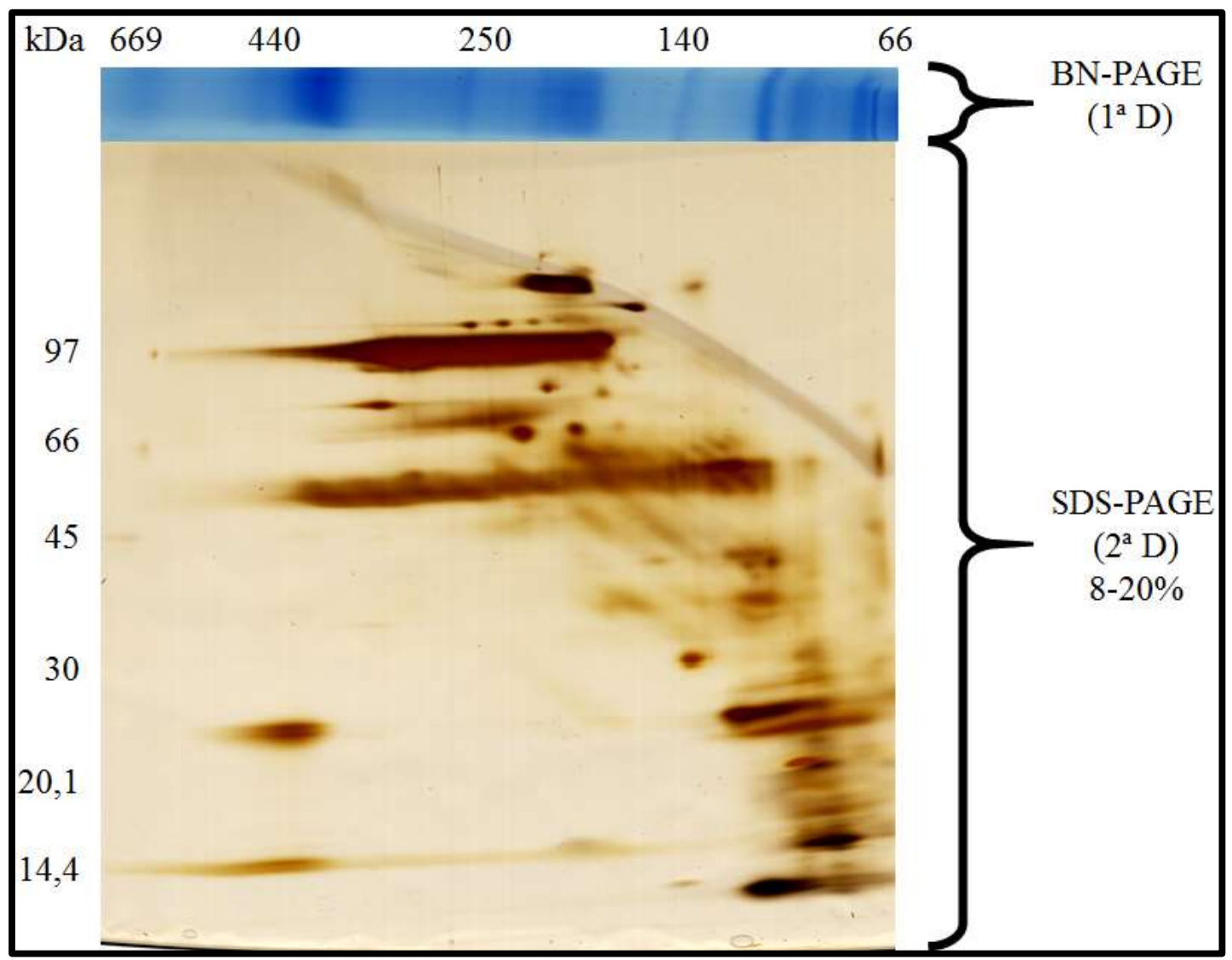

Figura 25. Eletroforese bidimensional BN/SDS-PAGE do secretoma cultivado em xilana oat spelts, com primeira dimensão em gradiente de poliacrilamida de 5-18\% e segunda dimensão com gradiente de poliacrilamida de 8-20\%. Gel corado com nitrato de prata.

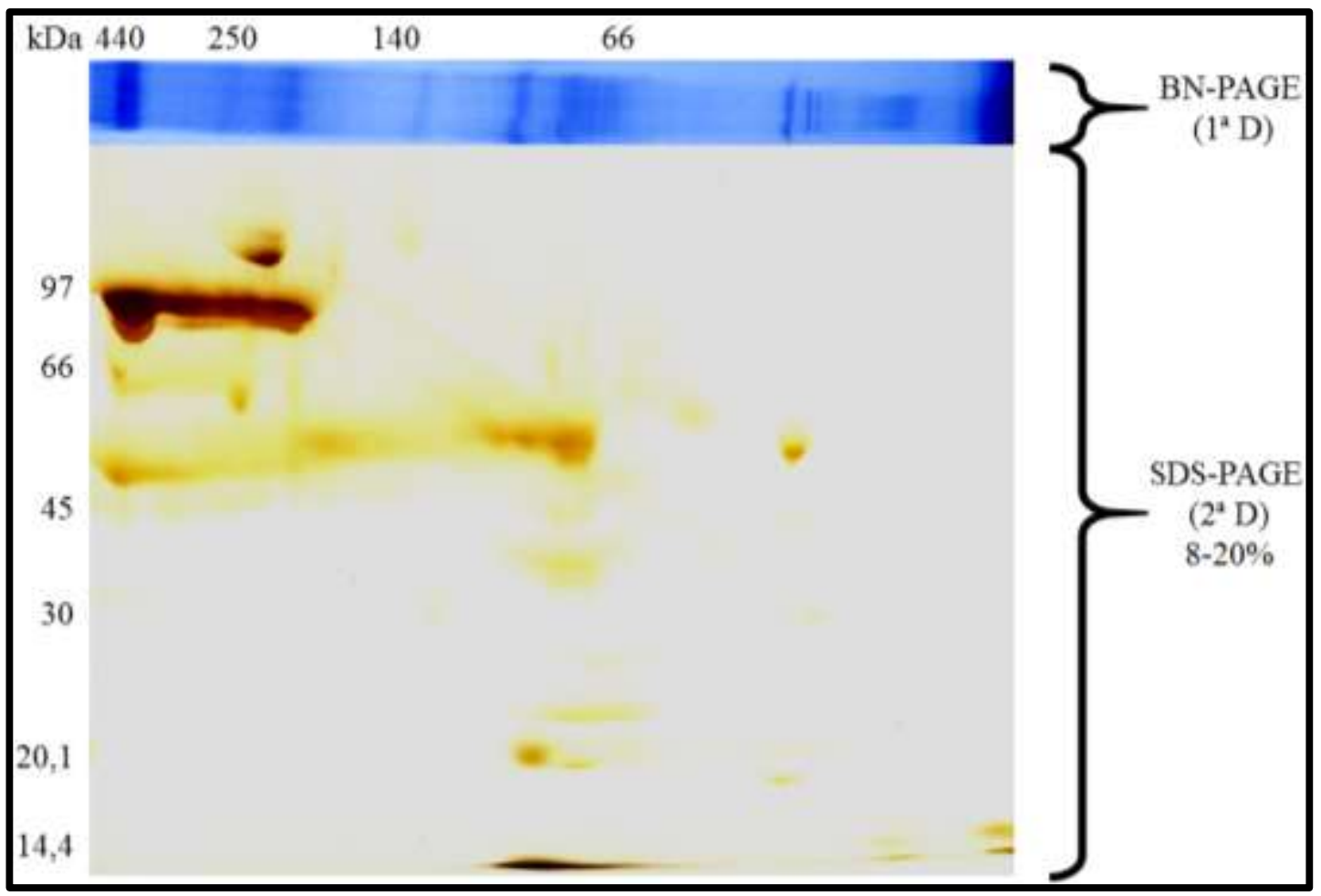

Figura 26. Eletroforese bidimensional BN/SDS-PAGE do secretoma cultivado em xilana oat spelts, com primeira dimensão em gradiente de poliacrilamida de $10-18 \%$ e segunda dimensão com gradiente de poliacrilamida de $8-20 \%$. Gel corado com nitrato de prata. 


\section{2) Espectrometria de massa - Identificações}

Para identificação por LC-MS/MS, vinte e sete bandas candidatas (sete em celulose, sete em xilana e treze em bagaço de cana) foram analisadas (Figura 27). Para a seleção das bandas, foram selecionadas bandas que possuíssem o maior número possível das seguintes características: alta massa molecular, alta intensidade, alta resolução e similaridade de massa com bandas de interesse em outras amostras. Para as proteínas com massa estimada acima de $440 \mathrm{kDa}$, a excisão foi feita no gel BN-PAGE com gradiente de 5-18\%. Já para as bandas com massa estimada abaixo de $440 \mathrm{kDa}$, preferiu-se fazer a excisão no BN-PAGE com gradiente de $10-18 \%$ devido à melhor resolução.

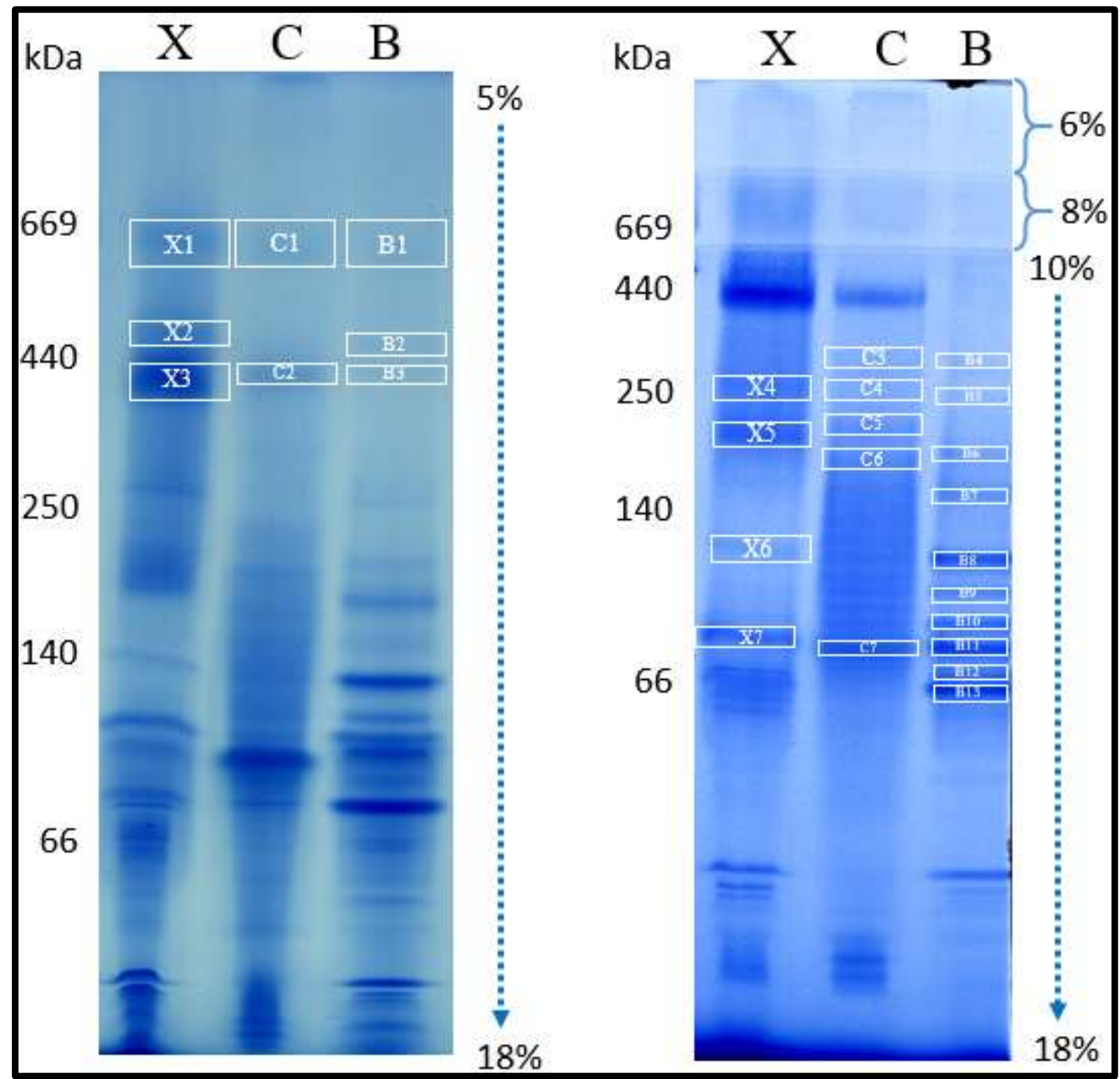

Figura 27. Bandas de possíveis complexos selecionadas em BN-PAGE para identificação por LC-MS/MS em LTQ-Orbitrap Elite.

A alta resolução é importante nesse tipo de análise para evitar contaminação entre bandas vizinhas. As bandas selecionadas estão distantes o bastante de bandas próximas para assegurar razoável segurança de que as identificações correspondem somente àquela banda. Contudo, em eletroforeses unidimensionais há sempre o risco de sobreposição de bandas, ou seja, que proteínas ou complexos proteicos de massa muito semelhante formem uma banda única. Por esse motivo, a utilização de técnicas como o 2-DE nativo (WEILAND et al., 2014) e o GELFrEE (SKINNER et al., 2015) poderia auxiliar no aumento da confiabilidade das identificações. 
Os géis bidimensionais mostrados demonstraram a presença de complexos devido à grande variedade de spots com diversas massas moleculares oriundos da decomposição das bandas da primeira dimensão. Contudo, o risco de que haja mais de um complexo formando uma mesma banda não foi descartado e, portanto, as identificações aqui apresentadas foram vistas com cautela. Além disso, se na estequiometria do complexo houver alguma subunidade repetida, não é possível saber disso somente pela análise da decomposição dos complexos, pois as bandas das subunidades repetidas ficam sobrepostas.

O programa PEAKS Studio 7,0 foi utilizado para a interpretação dos dados de espectrometria de massa, pois é capaz de incorporar os resultados dos sequenciamentos de novo nas buscas em bancos de dados e, com isso, gera resultados com sensibilidade e acurácia bastante elevados. A Taxa de Descobertas Falsas (FDR - False Discovery Rate) é uma medida dessa acurácia, definida como o percentual de falsas identificações dentre todas as identificações que obtiveram um score acima do limite delimitado pela busca. Quanto maior esse limite mínimo de score, maior é a confiabilidade da identificação (ZHANG et al., 2012).

O score do PEAKS Studio mede a qualidade dos matches de espectros peptídicos (PSMs) levando em conta não só a similaridade dos espectros de fragmentos iônicos experimentais com os espectros dos peptídeos do banco de dados digeridos in silico, mas também considerando diversos outros fatores como a similaridade entre o peptídeo sequenciado de novo com a sequência no banco de dados. As identificações proteicas são inferidas pelos PSMs, organizando as sequências peptídicas identificadas em proteínas. (REITER et al., 2009; ZHANG et al., 2012).

Nem todo PSM e identificação proteica são perfeitos. Para validar os resultados da busca em banco de dados, o programa PEAKS Studio utiliza uma versão aprimorada do método alvo-isca (target-decoy). Nesse método, os espectros de fragmentação obtidos experimentalmente são comparados a um bando de dados proteico quimérico, composto por todas as proteínas "alvo" possíveis para a amostra (banco de dados selecionado) e por um número igual de proteínas nonsense, as "iscas”. A taxa de identificações de proteínas "isca" é usada para estimar o número de falsos positivos para aquele espectro e, por consequência, a FDR.Como as identificações proteicas são realizadas juntando vários PSMs, erros de PSM se propagam na identificação proteica. Por isso, a FDR de uma proteína, na prática, é maior que a dos PSMs que compuseram a identificação (REITER et al., 2009; ZHANG et al., 2012).

A Figura 28 mostra a curva de FDR para os PSMs das análises realizadas como um todo, ou seja, para todas as 27 bandas de BN-PAGE em conjunto. Um total de 2618 espectros peptídicos tiveram menos de 1,0\% de FDR e, portanto, foram considerados na análise. Já a Figura 29 mostra a validação dos dados por meio do método alvo-isca, comparando PSMs e erros em ppm das proteínas do experimento e das proteínas "isca" em comparação com o banco de dados utilizado. O limite de score da busca, após a validação de dados, foi de 27,8 (indicado pela linha pontilhada vertical nas partes a e b da Figura 29) para peptídeos e 20,0 para proteínas.

Gráficos como os das duas figuras abaixo também foram obtidos individualmente para cada banda analisada. Ao todo, 130 proteínas foram identificadas por meio de 865 sequências peptídicas encontradas em 2618 PSMs. Dessas 130 proteínas, 43 apresentaram mais que 2 peptídeos únicos, 24 apresentaram exatamente 2 peptídeos únicos e 63 apresentaram apenas 1 peptídeo único. Com relação às modificações pós-traducionais, 
foram encontrados 1150 PSMs com deamidação de N e Q ( $\left.\Delta_{\text {massa }}=0,98 \mathrm{Da}\right), 177$ com oxidação de $\mathrm{M}\left(\Delta_{\text {massa }}=15,99 \mathrm{Da}\right)$ e 170 com carbamidometilação de $\mathrm{C}\left(\Delta_{\text {massa }}=57,02\right.$ $\mathrm{Da})$.

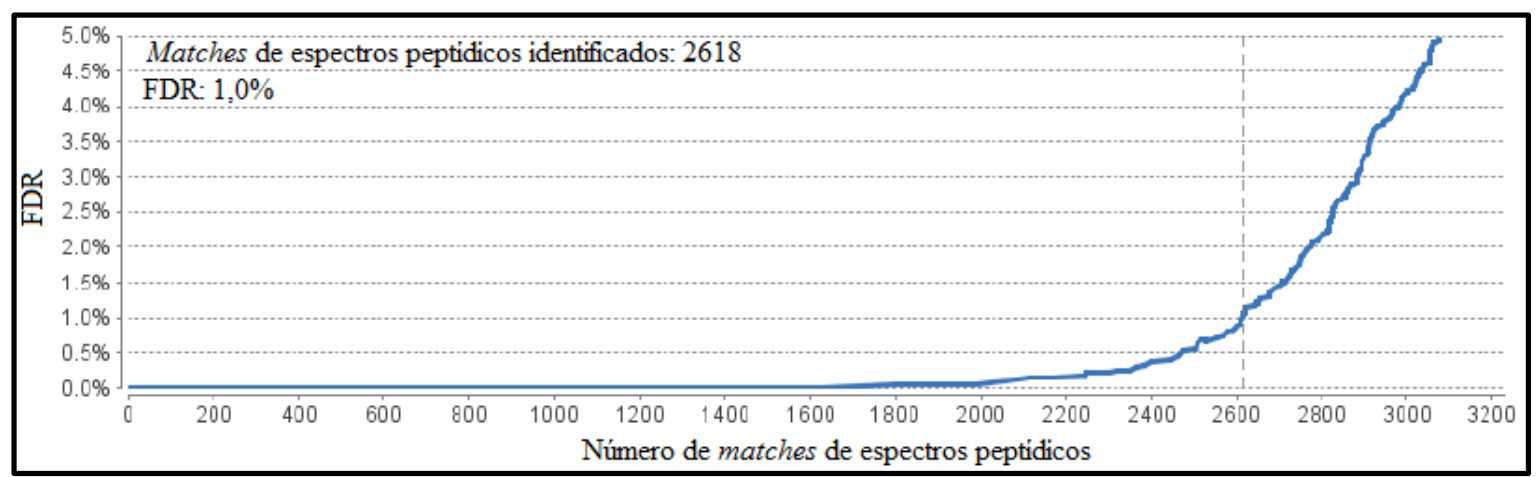

Figura 28. Curva FDR das identificações experimentais de todas as 27 bandas de BNPAGE analisadas em conjunto.

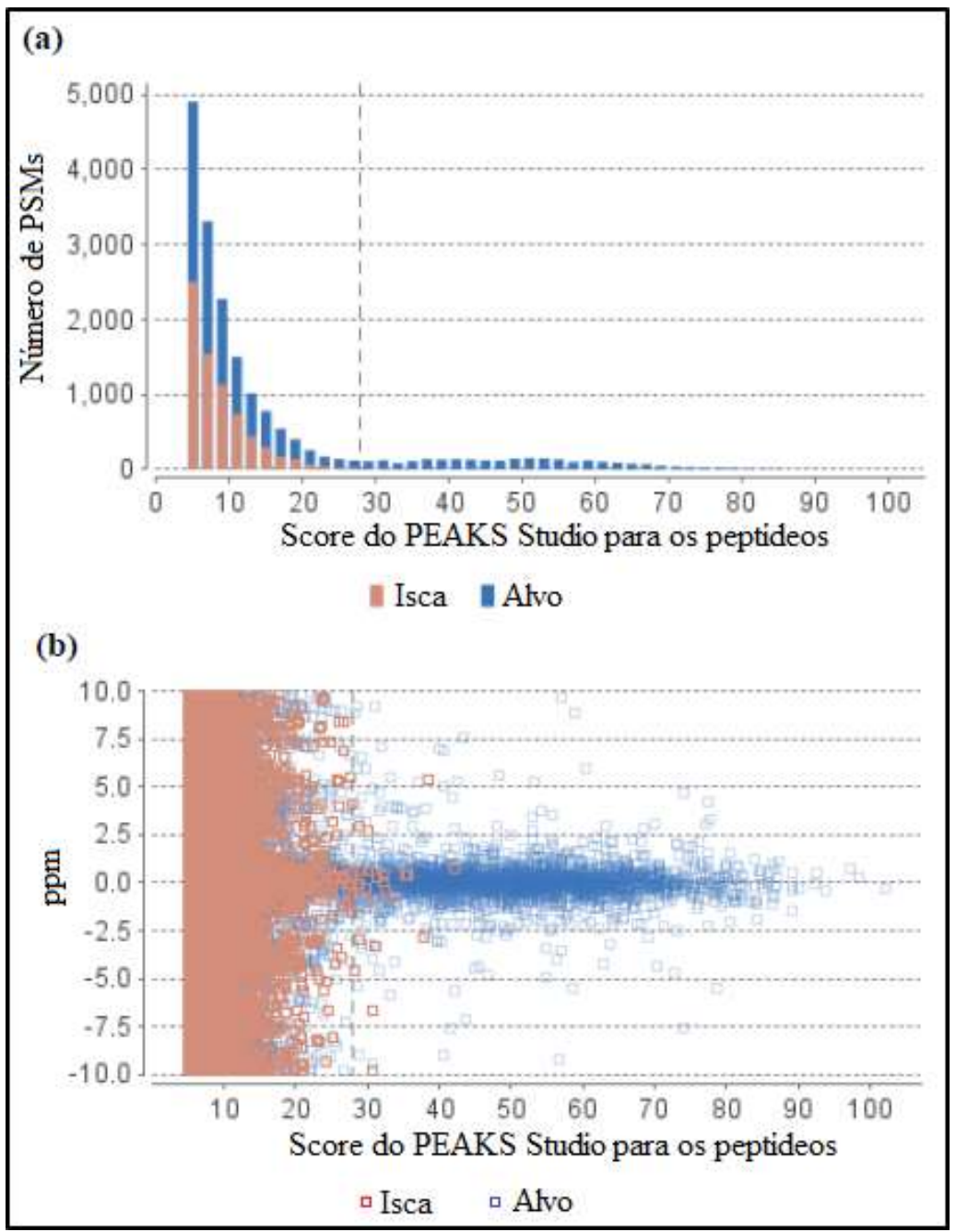

Figura 29. Distribuição dos matches de espectros peptídicos (PSMs) e validação alvo-isca para o experimento como um todo (todas as 27 bandas analisadas). Somente scores de PSMs acima de 27,8 foram considerados (indicado por linha pontilhada vertical). (a) Distribuição de scores por PSM. (b) Gráfico de dispersão dos scores por erro com relação à massa do precursor no experimento. 
Para cada proteína identificada, além de dados como o score, a cobertura percentual, o número de PSMs e de peptídeos únicos, a presença/ausência de PTMs e a massa molecular média, o programa forneceu uma imagem detalhada para a sequência de cada proteína, indicando quais peptídeos dela foram encontrados e com que PTMs. A Figura 30 é um exemplo disso, mostrando todos esses dados para a "proteína contendo domínio N-terminal da família glicosil hidrolase 3" no complexo C3. Figuras semelhantes foram obtidas para cada proteína identificada no experimento.

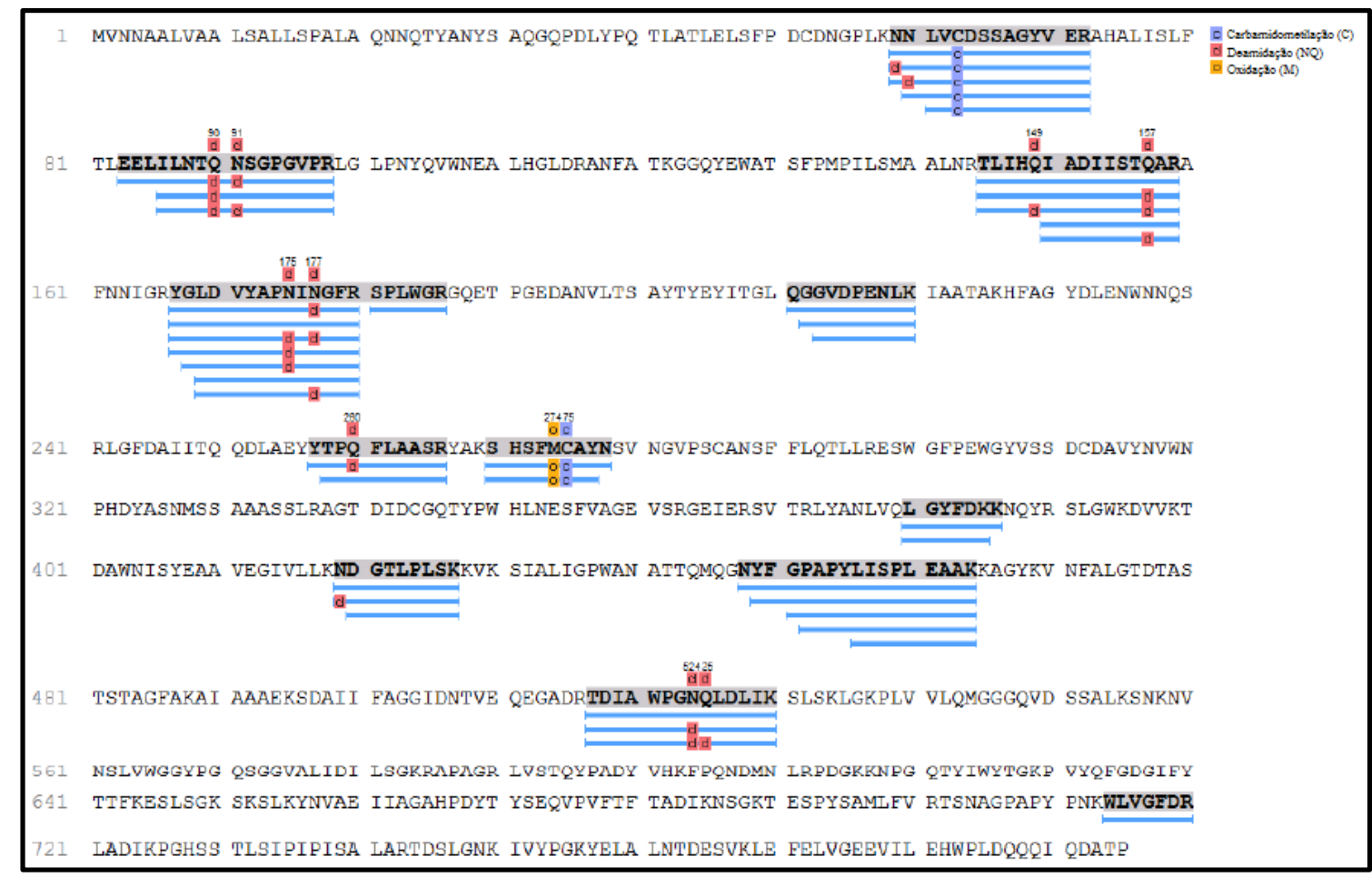

Figura 30. Exemplo de peptídeos-suporte para a identificação de uma proteína no experimento. A "proteína contendo domínio N-terminal da família glicosil hidrolase 3" foi identificada no complexo C3 devido à presença dos peptídeos representados pelas linhas azuis. Os resíduos destacados com fundo cinza estão na cobertura da proteína levando em conta todos os peptídeos identificados. As três PTMs consideradas na busca também estão destacadas quando presentes nas identificações (carbamidometilação de C, deamidação de $\mathrm{N}$ e Q e oxidação de $\mathrm{M}$ ).

Nas tabelas do material suplementar (seção 9, a partir da página 67) encontram-se os resultados sumarizados das identificações das proteínas digeridas a partir das 27 bandas de BN-PAGE excisadas, levando em conta os parâmetros discutidos até então. As proteínas identificadas como não-caracterizadas foram analisadas por Basic Local Alignment Search Tool (BLAST) no banco de dados UniProtKB, e a proteína com maior identidade está indicada em conjunto com o organismo dela na tabela. Nos casos em que houve duas proteínas com scores similares no BLAST, ambas estão indicadas. As bandas B8, B10 e B12 não retornaram nenhuma identificação (valores muito altos de FDR e score abaixo do mínimo), e os experimentos com elas precisarão ser refeitos.

Em cada tabela, além das identificações ainda estão indicados o Número de Acesso do UniProtKB, o score do PEAKS Studio, a cobertura, o número de peptídeos identificados, o número de peptídeos únicos encontrados, a presença/ausência das PTMs consideradas nos parâmetros de busca e a massa média das proteínas identificadas. 


\section{3) Separações eletroforéticas e espectrometria de massa - Considerações e interpretações técnicas}

A análise proteômica bottom-up pode ser convencionalmente realizada de duas formas: com proteínas isoladas ou com misturas complexas de proteínas. No primeiro caso, uma técnica de separação de proteínas (como uma 2-DE) é realizada e depois uma única proteína (como um spot do gel) é digerida e levada para identificação. Já a análise de misturas complexas, também conhecida como proteômica shotgun, se tornou viável com o surgimento da espectrometria de massa em tandem. Nesse tipo de análise, proteínas em uma mistura complexa são digeridas e seus peptídeos são separados por cromatografia líquida e analisados em conjunto no espectrômetro de massas (MCDONALD; YATES, 2002).

A análise dos complexos por BN-PAGE, como a do experimento realizado, é um excelente exemplo de meio-termo entre essas duas técnicas convencionais. Isso significa que um grupo de proteínas, presentes na banda excisada, foi digerido em conjunto e analisado no espectrômetro de massas. Houve uma redução na complexidade da amostra por meio da eletroforese nativa dos secretomas, que foi capaz de separar as proteínas em grupos, mas na cromatografia líquida (primeira etapa do LC-MS/MS) foram separados peptídeos oriundos de diversas proteínas, os quais foram analisados conjuntamente (MCDONALD; YATES, 2002).

O maior gargalo das análises shotgun, atualmente, é a quantidade de dados gerada e a sua análise. A interpretação dos espectros em sequências por meio de um número crescente de bancos de dados e o subsequente agrupamento das identificações dos peptídeos para concluir quais proteínas estavam na amostra exige muita capacidade computacional. Por fim, a interpretação dos resultados por parte do pesquisador a fim de dar sentido às identificações, separando as identificações verdadeiras dos falsos positivos, é um fator extremamente limitante na proteômica moderna (WU; MACCOSS, 2002).

Ainda que a abordagem do BN-PAGE acoplada ao LC-MS/MS seja um shotgun aplicado a uma mistura de proteínas menos complexa do que é convencional, a quantidade de dados obtida é ainda elevada o bastante para sua análise ser desafiadora. São muitas as informações que podem ser extraídas desses dados. Grande parte da análise comparativa do secretoma da $T$. harzianum cultivado em celulose, xilana e bagaço de cana já foi realizada por análise shotgun tradicional dos secretomas como um todo, com a digestão das proteínas dos secretomas e subsequente LC-MS/MS (GÓMEZMENDOZA et al., 2014).

No trabalho supracitado, os resultados foram encontrados por uma análise essencialmente desnaturante, portanto as proteínas foram analisadas independentemente de suas relações umas com as outras. $O$ trabalho concluiu haver uma enorme variação nas respostas às fontes de carbono utilizadas. Em testes de atividade enzimática, o secretoma cultivado em bagaço de cana apresentou as maiores atividades celulolítica e xilanolítica, mas curiosamente o secretoma cultivado em celulose apresentou maior diversidade de proteínas (GÓMEZ-MENDOZA et al., 2014).

Nas quatro fontes de carbono analisadas (celulose, xilana, glicose e bagaço de cana), somente $5 \%$ das proteínas identificadas eram comuns a todos os secretomas, enquanto $72 \%$ das proteínas identificadas foram encontradas exclusivamente em um só secretoma. Esse extensivo trabalho sugeriu, ainda, que a expressão das 5\% proteínas 
comuns às quatro condições tenha um mecanismo independente da fonte de carbono, já que elas eram majoritariamente proteínas de parede celular não-hidrolíticas, responsáveis pela solubilização e proximidade com o substrato (GÓMEZ-MENDOZA et al., 2014).

O presente trabalho, apesar de estar lidando com o mesmo fungo e três das fontes de carbono presentes no estudo citado nos parágrafos anteriores, teve um diferencial, que foi o fato de as proteínas terem sido separadas previamente de forma nativa. Foi, portanto, com essa ótica que os resultados foram aqui analisados e comparados à análise global e desnaturante já conhecida. O que se obteve aqui foi mais que uma lista de proteínas presentes em cada secretoma: foi um conjunto de listas de proteínas presentes em grupos em cada secretoma, o que adiciona uma dimensão extra à análise do que já se conhece das variações do secretoma de T. harzianum.

Após os processamentos de espectros pelo programa PEAKS Studio 7,0 no banco de dados do UniProtKB para a espécie $T$. harzianum e a análise por BLAST no UniProtKB para as proteínas classificadas como não-caracterizadas (dados apresentados nas Tabelas 6 a 32), as listas ainda são em sua maioria bastante extensas. Isso se dá porque algumas proteínas similares são identificadas com os mesmos peptídeos. Por exemplo, há três identificações para acetilxilanesterases no complexo X3 (Tabela 28), cada uma associada a um gene, mas as três identificações são baseadas no mesmo peptídeo (AAIFMGDPR, com oxidação na metionina). É possível que houvesse as três na mesma banda, mas também é possível que houvesse só uma ou duas delas. Para as análises aqui realizadas, foi considerada apenas uma das proteínas nesses casos de redundância de identificações.

Um outro problema que aumentou muito o tamanho das listas foi o fato de o PEAKS Studio ter sido programado para considerar proteínas com um número $\geq 1$ de peptídeos únicos. Apesar de os peptídeos terem sido todos identificados com um alto grau de confiança (score acima do determinado como confiável com base no método alvo-isca, Figura 29), muitos deles são pequenos e representam coberturas baixíssimas das proteínas quando há somente um peptídeo exclusivo.

Além disso, como a análise é baseada em bancos de dados, uma mutação que altere um único resíduo de aminoácido para uma proteína presente na amostra pode gerar um falso positivo para uma proteína que não está na amostra. Um problema inverso também é possível, que é o peptídeo presente na amostra ser uma versão mutada do que está no banco de dados, prevenindo a identificação. Os algoritmos utilizados pelos programas que fazem a identificação das proteínas por meio dos espectros tentam levar essas questões em consideração, dando alguma flexibilidade à análise, mas nenhum deles é perfeito (CARR et al., 2004).

A validação dos resultados é uma parte ainda desafiadora da proteômica moderna, e todo cuidado é pouco para assegurar uma alta confiabilidade e reprodutibilidade desse tipo de experimentos. A comunidade proteômica internacional tem estado atenta a isso, discutindo o assunto e promovendo guias cada vez mais estritos para a publicação de dados proteômicos (BINZ et al., 2008; CARR et al., 2004; DEUTSCH et al., 2016; GU; YU, 2014; LATTERICH, 2006; TABB, 2008; WILKINS et al., 2006).

O risco de identificação de falsos positivos é mais alto quando a proteína é identificada com um único peptídeo exclusivo. Isso não significa que proteínas com dois ou mais peptídeos exclusivos sejam necessariamente identificações corretas, mas a probabilidade aumenta exponencialmente uma vez que cada um dos peptídeos de suporte passou pela validação estatística (CARR et al., 2004). Uma proteína com 29 peptídeos 
únicos, como a "Glycosyl hydrolase family $3 \mathrm{~N}$ terminal domain-containing protein" na banda C3 (Tabela 21, Figura 30), é uma identificação muito mais confiável que uma identificada com somente 1 peptídeo único, como é o caso do fragmento de actina na mesma banda.

Portanto, para as análises aqui realizadas foram consideradas somente aquelas com um número $\geq 2$ peptídeos únicos. Ainda assim, proteínas com um número "baixo" (não definido) de peptídeos únicos devem ser olhadas com uma dose saudável de ceticismo, especialmente se a cobertura for muito baixa. Proteínas não caracterizadas também devem ser vistas com ressalvas, apesar de a maioria delas ter encontrado correlações com altas identidades dentro do próprio gênero Trichoderma. No entanto, isso já reduz a lista de proteínas identificadas de maneira significativa e eleva bastante a confiança geral da análise dos dados aqui apresentados.

Infelizmente, no entanto, há uma grande perda de identificações de verdadeiros positivos na exclusão das proteínas com somente um peptídeo único. A prática de excluir proteínas com menos de dois peptídeos únicos, nos filtros, é comum em estudos proteômicos devido ao risco de falsos positivos potencializado nas proteínas identificadas somente com um peptídeo, as one-hit-wonders. Um estudo com a bactéria Shewanella oneidensis demonstrou que cerca de $80 \%$ das one-hit-wonders realmente estavam presentes nas amostras (GUPTA; PEVZNER, 2009).

A questão é mais complexa do que a intuição parece sugerir. A hipótese de que dois peptídeos identificados com scores x e y (em uma mesma proteína) são uma evidência melhor para a expressão da proteína que um peptídeo único com score $\mathrm{z}$, sendo que $z=x+y$, nem sempre é verdadeira. Isso depende muito dos valores de $\mathrm{x}, \mathrm{y}$ e $\mathrm{z}$ e do tamanho da proteína em questão. Um estudo a respeito da metodologia comum de excluir proteínas com menos de dois peptídeos únicos identificados sugere que a prática seja abandonada e que os scores das proteínas como um todo sejam considerados (GUPTA; PEVZNER, 2009).

Uma outra etapa a ser considerada na interpretação das identificações é se cada banda realmente corresponde a um complexo. Eletroforeses em gradiente têm uma grande vantagem em permitir a separação mesmo de proteínas com massas similares, mas ainda assim um risco conhecido da eletroforese em geral (e, em especial, da unidimensional) é o de sobreposição de bandas. Esse risco é maior quanto maior é a complexidade do perfil eletroforético. As eletroforeses bidimensionais conseguem reduzir muito esse risco ao acrescentar mais um parâmetro de separação, e o 2-DE nativo é uma maneira de usar esse benefício para aumentar a confiabilidade da separação de complexos (WEILAND et al., 2014).

No entanto, a eletroforese nativa utilizada aqui foi o BN-PAGE unidimensional tradicional e, por isso, foi importante ter cautela para determinar se uma banda levada para identificação é única ou múltipla. Selecionando-se uma banda aleatoriamente em um gel unidimensional, é sempre um risco que a banda seja múltipla. Quando o universo de bandas é reduzido de "todas as bandas do gel" para "bandas mais intensas do gel", como foi o procedimento adotado nesse trabalho, a probabilidade de sobreposição acaba aumentando muito, já que uma alta intensidade de coloração da banda pode significar não só mais alta expressão de um só complexo, mas também uma expressão normal de dois ou mais complexos sobrepostos.

O critério "banda intensa" foi utilizado na seleção de bandas para a análise na esperança de corresponder ao primeiro caso, ou seja, uma alta expressão do complexo. 
Para ter confiança de que foi isso mesmo o que ocorreu, é possível realizar uma estimativa da massa de cada banda do BN-PAGE $( \pm 20 \%$ de erro, como já discutido no primeiro parágrafo após a Figura 16) e comparar essa massa com a soma das massas das proteínas identificadas. Essa estimativa pode ser feita através da plotagem de um gráfico que indica o fator de retenção $(R f)$ das bandas do marcador do gel em função do logaritmo em base 10 da massa molecular $(M w)$ das bandas do marcador. O $R f$ é calculado como a razão da distância percorrida pela banda no gel e do tamanho total do gel. Com base nisso, uma regressão linear pode ser realizada para a obtenção de uma equação que é utilizada para estimar a massa molecular das bandas analisadas.

Com o programa Microsoft Excel, foram determinados os gráficos de correlação e equações de regressão linear para os géis BN-PAGE com gradiente de 5-18\% (Figura 31), utilizado para as bandas $X_{1-3}, C_{1-2}$ e $B_{1-3}$, e com gradiente de 10-18\% (Figura 32), utilizado para as bandas $\mathrm{X}_{4-7}, \mathrm{C}_{3-7}$ e $\mathrm{B}_{4-13}$.

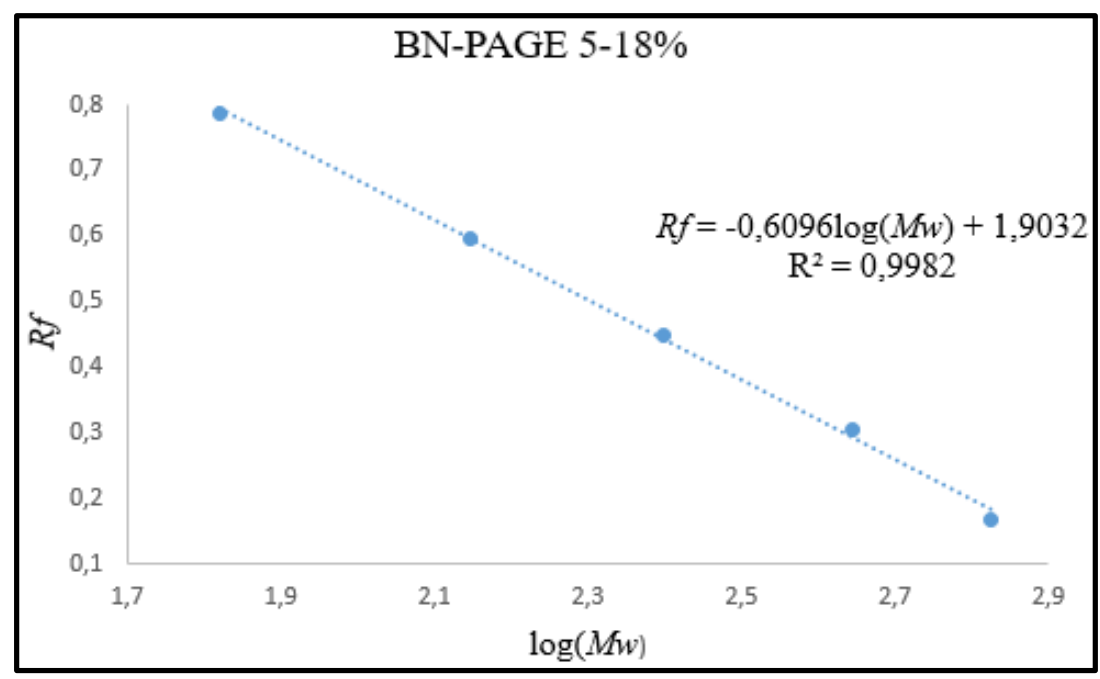

Figura 31. Regressão linear simples para o fator de retenção no gel BN-PAGE 5-18\% em função do logaritmo em base 10 da massa molecular dos marcadores (citados na metodologia).

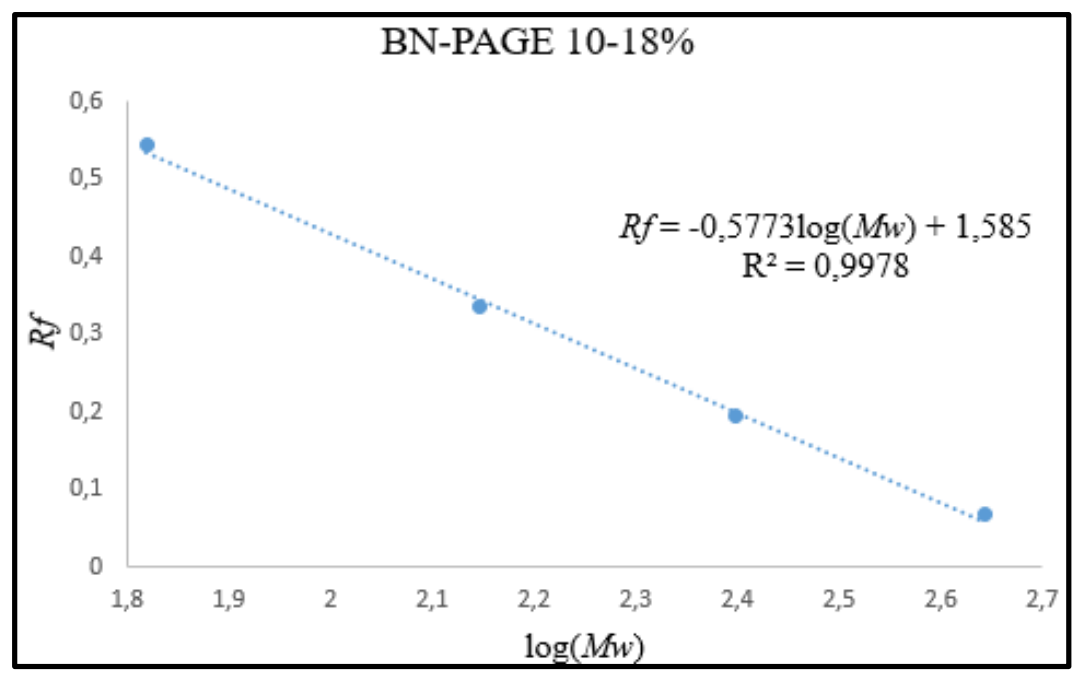

Figura 32. Regressão linear simples para o fator de retenção no gel BN-PAGE 10-18\% em função do logaritmo em base 10 da massa molecular dos marcadores (citados na metodologia). 
Substituindo o valor de $R f$ de cada banda analisada na equação do gel correspondente, foi possível fazer uma estimativa da massa de cada uma delas (Tabela 3).

Tabela 3. Estimativa de massa das bandas dos géis BN-PAGE analisadas por LC-MS/MS, com erro de $\pm 20 \%$.

\begin{tabular}{|c|c|c|}
\hline Banda & $\boldsymbol{R} \boldsymbol{c}$ & $\begin{array}{c}\boldsymbol{w} \boldsymbol{w} \text { estimada } \\
\text { (kDa) }\end{array}$ \\
\hline B1 & 0,1818 & $666 \pm 133$ \\
\hline B2 & 0,2828 & $455 \pm 91$ \\
\hline B3 & 0,3131 & $406 \pm 81$ \\
\hline B4 & 0,1463 & $310 \pm 62$ \\
\hline B5 & 0,1951 & $256 \pm 51$ \\
\hline B6 & 0,2622 & $196 \pm 39$ \\
\hline B7 & 0,3170 & $157 \pm 31$ \\
\hline B8 & 0,3902 & $117 \pm 23$ \\
\hline B9 & 0,4329 & $99 \pm 20$ \\
\hline B10 & 0,4634 & $88 \pm 18$ \\
\hline B11 & 0,4939 & $78 \pm 16$ \\
\hline B12 & 0,5244 & $69 \pm 14$ \\
\hline B13 & 0,5488 & $62 \pm 12$ \\
\hline C1 & 0,1818 & $666 \pm 133$ \\
\hline C2 & 0,3131 & $406 \pm 81$ \\
\hline C3 & 0,1463 & $310 \pm 62$ \\
\hline C4 & 0,1890 & $262 \pm 52$ \\
\hline C5 & 0,2256 & $226 \pm 45$ \\
\hline C6 & 0,2683 & $191 \pm 38$ \\
\hline C7 & 0,5012 & $75 \pm 15$ \\
\hline X1 & 0,18182 & $666 \pm 133$ \\
\hline X2 & 0,27273 & $473 \pm 95$ \\
\hline X3 & 0,32323 & $391 \pm 78$ \\
\hline X4 & 0,1829 & $268 \pm 54$ \\
\hline X5 & 0,2378 & $216 \pm 43$ \\
\hline X6 & 0,3780 & $123 \pm 25$ \\
\hline X7 & 0,4878 & $80 \pm 16$ \\
\hline & & \\
\hline
\end{tabular}

As massas estimadas por meio dessa análise puderam, então, ser comparadas à soma das massas das identificações para facilitar a interpretação das bandas em um ou mais complexos. Ainda assim é uma análise que não resolveria o problema com segurança, já que não se sabe exatamente quais identificações são corretas e quais são falsos positivos. Além disso, também é possível que alguma proteína presente na banda não tenha sido identificada. Somando tudo isso ao fato de que o erro estimado à massa da banda como um todo é de $\pm 20 \%$, é ainda mais difícil estabelecer quais bandas são um só complexo e quais representam sobreposições.

Na Tabela 4 foi realizada essa comparação em dois estágios: fazendo a soma de massas de todas as identificações dadas nas tabelas de identificação, e fazendo a soma de massas somente das identificações com um número de peptídeos únicos maior ou igual a 2 e sem redundância (proteínas diferentes identificadas exclusivamente com os mesmos 
peptídeos). Nos casos em que havia um só peptídeo único e diversos outros não-únicos, a proteína foi considerada no filtro. Também foram apresentadas na tabela as variações percentuais dos valores encontrados com relação à estimativa de massa da banda. Embora, como já discutido, não seja ideal excluir as one-hit-wonders, como não foi possível repetir o experimento para uma maior validação dos dados, essa estratégia foi a mais segura (apesar de gerar perdas de verdadeiros positivos).

Tabela 4. Comparação entre as massas estimadas na tabela anterior e a soma das massas das tabelas de identificação, sem filtros e com filtros. Os filtros são: remoção de redundâncias e número de peptídeos únicos $\geq 2$ (exceto quando há outros não únicos).

\begin{tabular}{|c|c|c|c|c|c|}
\hline Banda & $\begin{array}{c}\text { Massa } \\
\text { estimada } \\
\text { da banda } \\
\text { (kDa) }\end{array}$ & $\begin{array}{c}\text { imassas das } \\
\text { identificações } \\
\text { sem filtros } \\
\text { (kDa) }\end{array}$ & $\begin{array}{c}\text { Variação \% } \\
\text { com a massa } \\
\text { da banda }\end{array}$ & $\begin{array}{c}\text { massas das } \\
\text { identificações } \\
\text { com filtros } \\
\text { (kDa) }\end{array}$ & $\begin{array}{c}\text { Variação \% } \\
\text { com a massa } \\
\text { da banda }\end{array}$ \\
\hline B1 & 666 & 101 & $-85 \%$ & 56 & $-92 \%$ \\
\hline B2 & 455 & 943 & $+107 \%$ & 133 & $-71 \%$ \\
\hline B3 & 406 & 554 & $+36 \%$ & 332 & $-18 \%$ \\
\hline B4 & 310 & 1409 & $+354 \%$ & 644 & $+107 \%$ \\
\hline B5 & 256 & 633 & $+147 \%$ & 174 & $-32 \%$ \\
\hline B6 & 196 & 1065 & $+443 \%$ & 691 & $+252 \%$ \\
\hline B7 & 157 & 1152 & $+634 \%$ & 348 & $+122 \%$ \\
\hline B8 & 117 & - & - & - & - \\
\hline B9 & 99 & 776 & $+684 \%$ & 481 & $+385 \%$ \\
\hline B10 & 88 & - & - & - & - \\
\hline B11 & 78 & 769 & $+886 \%$ & 474 & $+507 \%$ \\
\hline B12 & 69 & - & - & - & - \\
\hline B13 & 62 & 1237 & $+1895 \%$ & 634 & $+922 \%$ \\
\hline C1 & 666 & 325 & $-51 \%$ & 137 & $-79 \%$ \\
\hline C2 & 406 & 766 & $+89 \%$ & 288 & $-29 \%$ \\
\hline C3 & 310 & 1507 & $+386 \%$ & 614 & $+98 \%$ \\
\hline C4 & 262 & 1676 & $+540 \%$ & 753 & $+187 \%$ \\
\hline C5 & 226 & 2115 & $+836 \%$ & 939 & $+315 \%$ \\
\hline C6 & 191 & 1221 & $+539 \%$ & 655 & $+243 \%$ \\
\hline C7 & 75 & 3075 & $+4000 \%$ & 565 & $+653 \%$ \\
\hline X1 & 666 & 510 & $-23 \%$ & 211 & $-68 \%$ \\
\hline X2 & 473 & 1292 & $+173 \%$ & 601 & $+27 \%$ \\
\hline X3 & 391 & 1589 & $+306 \%$ & 980 & $+151 \%$ \\
\hline X4 & 268 & 1680 & $+527 \%$ & 1248 & $+366 \%$ \\
\hline X5 & 216 & 1756 & $+713 \%$ & 1429 & $+562 \%$ \\
\hline X6 & 123 & 1984 & $+1513 \%$ & 1097 & $+792 \%$ \\
\hline X7 & 80 & 1443 & $+1704 \%$ & 611 & $+664 \%$ \\
\hline
\end{tabular}

As variações de massa, mesmo com a aplicação dos filtros, são extremamente altas. Esse fato favorece a hipótese de que a seleção de bandas intensas favoreceu, também, a seleção de bandas sobrepostas. As maiores variações estão nas bandas de menor massa, uma região mais densamente populosa de bandas no perfil eletroforético das amostras. Outra possibilidade para essas variações é a alta sensibilidade do aparelho 
Orbitrap Elite, que pode ter conseguido identificar proteínas que passaram pela banda (arrastes) ao longo da corrida deixando resquícios.

Há, ainda, bandas com variação negativa de massas (somas correspondem a uma massa menor que a estimada da banda). Isso pode se dever ao fato de que nem todas as proteínas tiveram peptídeos identificados, já que essas bandas eram bem pouco intensas e foram selecionadas principalmente por sua grande massa. Outra possibilidade é que as proteínas identificadas estejam presentes com mais de uma subunidade em um ou mais tipos de proteínas, o que contribuiria para o complexo ser de tão alta massa.

Em síntese, a estratégia de acoplar o BN-PAGE ao LC-MS/MS se mostrou pouco confiável, devido ao grande número de variáveis em gel e na estratégia shotgun sobre os quais não é simples manter o controle. Os trabalhos previamente realizados em nosso grupo de pesquisa com essa estratégia e fungos do gênero Trichoderma não levantaram essas possibilidades em suas discussões. As comparações das massas de identificações com as massas das bandas não foram feitas sob a alegação de que as estimativas das massas de BN-PAGE são pouco confiáveis, o que é verdade e também foi discutido aqui. Ambos os trabalhos partiram do pressuposto de que cada banda corresponderia a um único complexo e seguiram com as análises, inclusive propondo mecanismos de sinergia entre as enzimas dentro dos supostos complexos (DA SILVA et al., 2012, 2015).

No entanto, como foi demonstrado na Tabela 4, os erros estão muito acima dos conhecidos para a técnica BN-PAGE, o que levanta suspeitas ainda que não seja possível calcular com acurácia de quanto é esse erro. Outra razão pela qual a análise de bandas nativas, em oposição às subunidades de compostas em gel 2D, foi preferida nesses artigos foi a preocupação de que as decomposições podiam ser incompletas na segunda dimensão, havendo perda identificação de proteínas do complexo. É uma preocupação válida, mas ainda assim não seria possível evitar a sobreposição de bandas, já que as subunidades de todos os complexos presentes na banda da primeira dimensão estariam numa mesma linha vertical no gel de segunda dimensão (DA SILVA et al., 2012, 2015).

A estratégia experimental utilizada, portanto, não se mostrou adequada para fazer análises detalhadas dos complexos. No entanto, foi suficiente para se atingir os objetivos desejados para esse trabalho, pois com os géis bidimensionais BN/SDS-PAGE e as identificações foi possível verificar que há, sim, a presença de complexos multienzimáticos nas três condições, os complexos são diferentes entre as condições e são presentes neles enzimas capazes de atuar em diferentes substratos mesmo quando só um tipo de substrato é oferecido.

Esse último resultado é coerente com a análise desnaturante shotgun dos secretomas, na qual também foram encontradas enzimas não-específicas da fonte de carbono. Esse fato provavelmente se deve ao fato de que, ao longo da evolução, esses microrganismos não tiveram contato com fontes tão definidas de carbono. A biomassa de que se alimentam é bastante complexa e, por isso, ao longo da evolução faz sentido não terem sido desenvolvidos mecanismos tão finos de sinalização para a expressão das enzimas (GÓMEZ-MENDOZA et al., 2014). 


\section{4) Proteínas identificadas - Discussão das identificações de maior confiança}

Outra análise que os dados obtidos permitem realizar é a da distribuição das proteínas entre as fontes de carbono. Embora, como já discutido, não tenha sido possível dizer exatamente quantos complexos são e quais os componentes exatos de cada um, o conjunto de cada tipo de lista (bagaço, celulose e xilana) representa conjuntos de proteínas que estão presentes em complexos. É, ainda, possível comparar a distribuição das proteínas complexadas nos secretomas com a distribuição obtida na pesquisa shotgun envolvendo o secretoma como um todo (GÓMEZ-MENDOZA et al., 2014).

Para isso, foi utilizado o programa Venny 2.1 (OLIVEROS, 2015) para produzir diagramas de Venn, uma representação matemática útil para o estudo de conjuntos de dados. Neles, é possível visualizar quantos dados estão presentes exclusivamente em algum conjunto, em dois conjuntos mas não em um terceiro e nos três conjuntos. $\mathrm{O}$ resultado está representado na Figura 33, tanto para os dados sem filtros como para os dados com os filtros já discutidos para a Tabela 4. Os percentuais de proteínas presentes em mais de uma fonte de carbono não variaram muito, enquanto houve variação maior no grupo das proteínas exclusivas de uma só fonte de carbono (aumento no bagaço e redução drástica na celulose).

Isso provavelmente se deve ao fato de que o uso dos filtros removeu muitos falsos positivos de proteínas "aleatórias" que acabavam aparecendo somente em um dos secretomas. Por exemplo, em números absolutos, as proteínas exclusivas da celulose caíram de 28 para apenas 4 . Já dentre as proteínas que apareciam em mais de um secretoma, a quantidade de falsos positivos parece ter sido menor, o que reforça a confiança nessas identificações quando os filtros foram aplicados.

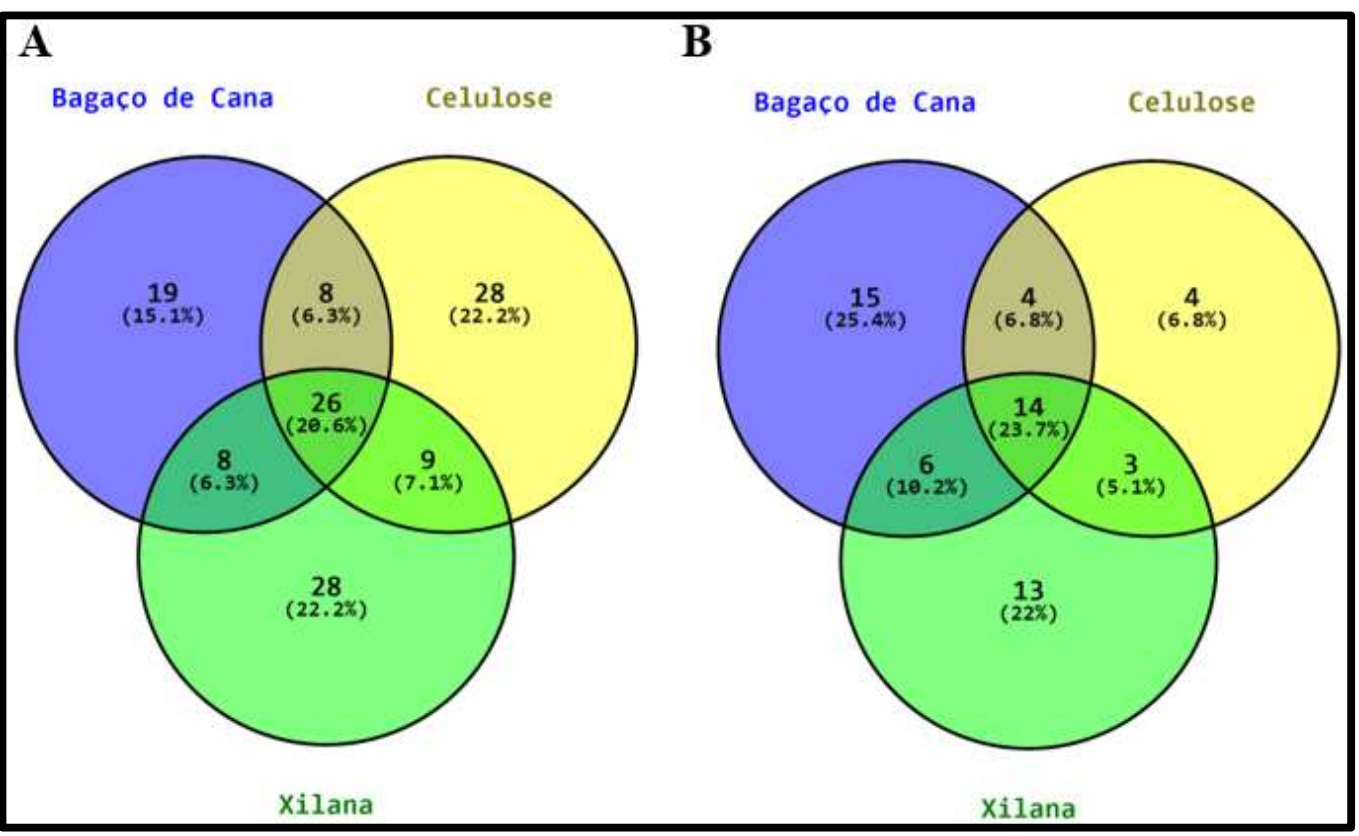

Figura 33. Diagramas de Venn para a distribuição das proteínas em complexos nas três fontes de carbono estudadas. (A) Proteínas retiradas das tabelas de identificação sem filtros. (B) Proteínas retiradas das tabelas de identificação com filtros (sem proteínas redundantes, número de peptídeos únicos $\geq 2$ ). Imagens montadas no programa Venny 2.1 (OLIVEROS, 2015). 
O trabalho shotgun citado também utilizou o programa Venny 2.1 para analisar seus dados gerais de proteínas. No entanto, como nesse trabalho houve uma quarta fonte de carbono (glicose), para permitir a comparação com o meu trabalho a figura do trabalho foi refeita para remover a glicose e realocar as proteínas presentes em cada conjunto para permitir a visualização somente das proteínas das mesmas fontes de carbono que foram utilizadas no presente trabalho (Figura 34).

Comparando o diagrama do presente trabalho (com filtros) da Figura 33 com o diagrama do trabalho shotgun da Figura 34 é possível perceber algumas alterações nos padrões de distribuição. As conclusões não são definitivas porque o universo do presente trabalho não envolve todas as proteínas complexadas (nem todas as bandas do BN-PAGE foram analisadas), enquanto o trabalho shotgun trabalhou com quase todas as proteínas do secretoma (tantas quanto foi possível identificar). Além disso, mais bandas de bagaço de cana foram analisadas que bandas dos outros secretomas, o que enviesa um pouco a análise.

Embora no secretoma em xilana a proporção de proteínas únicas da análise desnaturante seja similar à de proteínas únicas presentes em complexos, no bagaço de cana é um pouco menor e na celulose é muito maior. Já as proteínas presentes em todos os secretomas tiveram maior número no diagrama de figuras complexadas, aproximadamente o dobro. Isso parece sugerir que um número relativamente restrito de proteínas seja responsável pela formação dos complexos proteicos, independente da fonte de carbono. Não é conhecida para Trichoderma uma proteína como a escafoldina do celulossoma, ponto de apoio para a formação de complexos. No entanto, quase um quarto das proteínas presentes em complexos são as mesmas para as três fontes de carbono, o que sugere que possa haver grupos de proteínas realizando uma função similar à da escafoldina na montagem de complexos nesse gênero de fungo filamentoso.

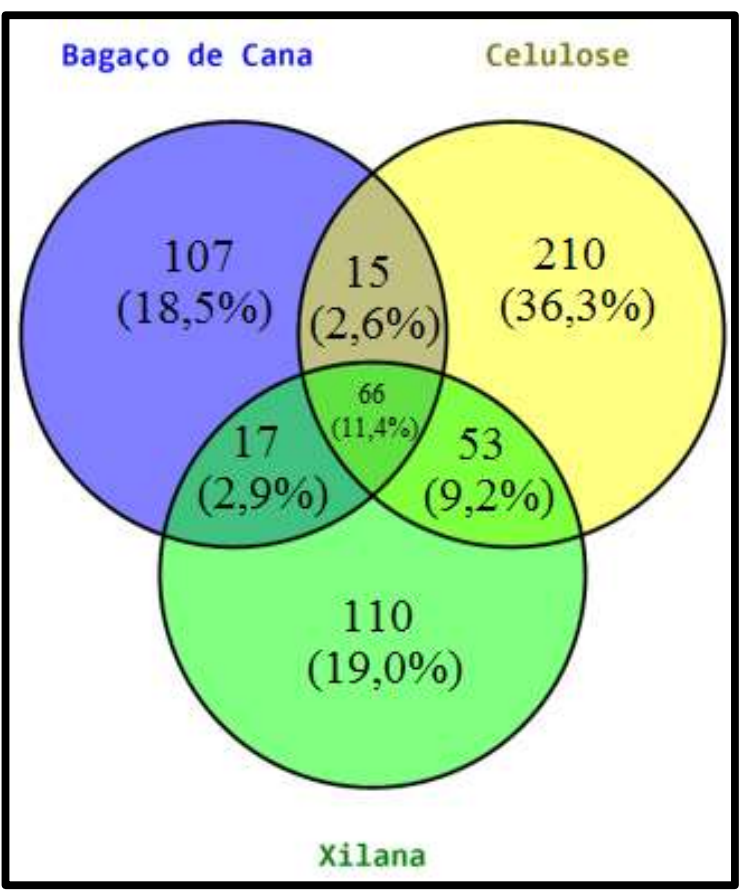

Figura 34. Adaptação do diagrama de Venn feito para a análise shotgun do secretoma de T. harzianum em quatro fontes de carbono (bagaço de cana, xilana, celulose e glicose). A glicose foi removida da figura original, com as sobreposições reordenadas para os outros conjuntos. Dados retirados de (GÓMEZ-MENDOZA et al., 2014). 
Os diagramas de Venn são muito úteis para a visualização quantitativa das diferenças de diversidade proteica entre os meios de cultivo. No entanto, não permitem a visualização qualitativa comparativa dos resultados. Para isso, foi montada a Tabela 5, na qual as 22 proteínas de mais alto score na lista global estão colocadas em ordem decrescente de score e as células correspondentes a cada uma das bandas estão preenchidas se a proteína se encontra naquela banda ou em branco se a proteína não se encontra naquela banda. Foi utilizada, para isso, a lista de proteínas com filtros (sem proteínas redundantes, com número de peptídeos únicos $\geq 2$ exceto quando houver mais peptídeos-suporte não únicos).

Muitas das proteínas que estão sem preenchimento em determinadas bandas na verdade aparecem nas tabelas de identificação, mas não se qualificaram nos filtros. É possível que elas realmente estejam lá, mas a identificação não foi confiável como nas bandas nas quais a célula está preenchida. Portanto, a ausência de preenchimento não significa, necessariamente, ausência da proteína naquela banda. O objetivo da tabela foi exibir para comparação somente as identificações de mais alta confiança. Foi possível, dessa forma, observar padrões de distribuição das proteínas em cada um dos complexos (ou conjuntos de complexos) das bandas do BN-PAGE.

A "Glycosyl hydrolase family $3 \mathrm{~N}$ terminal domain-containing protein", proteína com mais alto score na lista global de identificações, aparece em quase todas as bandas do cultivo em celulose e xilana, mas não nas bandas do cultivo em bagaço de cana. A família 3 de Glicosil Hidrolases (GH3) abrange cerca de 100 glicosil hidrolases, das quais a maioria tem a função de $\beta$-glicosidase (HARVEY et al., 2000). As $\beta$-glicosidases, como foi mostrado na Figura 4, hidrolisam a celobiose oriunda da clivagem da celulose por celobiohidrolases. Nessa família também são encontradas $\beta$-xilosidases e $\mathrm{N}$ acetilglucosaminidases. Essas enzimas são descritas como importantes em funções housekeeping dos organismos, além das suas interações com o ambiente (incluindo interações patógeno-hospedeiro) (COURNOYER; FAURE, 2003).

As funções da família GH3 podem ser resumidas em três principais: a biodegradação e assimilação de diversos carboidratos e glicoconjugados; a modificação da atividade biológica de glicoconjugados como antibióticos bacterianos e antifúngicos vegetais; e a reciclagem de componentes da arquitetura celular, como os polímeros de parede celular (COURNOYER; FAURE, 2003).

Como a proteína identificada contém um domínio N-terminal de GH3, sem função descrita, não está claro qual dessas funções estaria ocorrendo. $\mathrm{O}$ fato de a proteína aparecer em quase todas as bandas do cultivo em celulose faria sentido se a função for de $\beta$-glicosidase. Porém, se fosse essa a função, possivelmente a proteína seria observada também no cultivo com bagaço de cana (que tem celulose na composição), e talvez não fosse observada em quase todas as bandas do cultivo em xilana. Um raciocínio análogo pode ser feito se a função for de $\beta$-xilosidase, ou seja, faria sentido ela estar presente nas bandas do cultivo em xilana, mas não seria coerente estar presente também no cultivo em celulose e não no em bagaço de cana (que tem xilana na composição). 
Tabela 5. Distribuição das 22 proteínas de mais alto score global, em ordem decrescente de cima para baixo, em cada banda analisada dos géis BN-PAGE por LC-MS/MS. As cédulas preenchidas indicam presença, e as em branco indicam ausência (de acordo com os filtros utilizados).

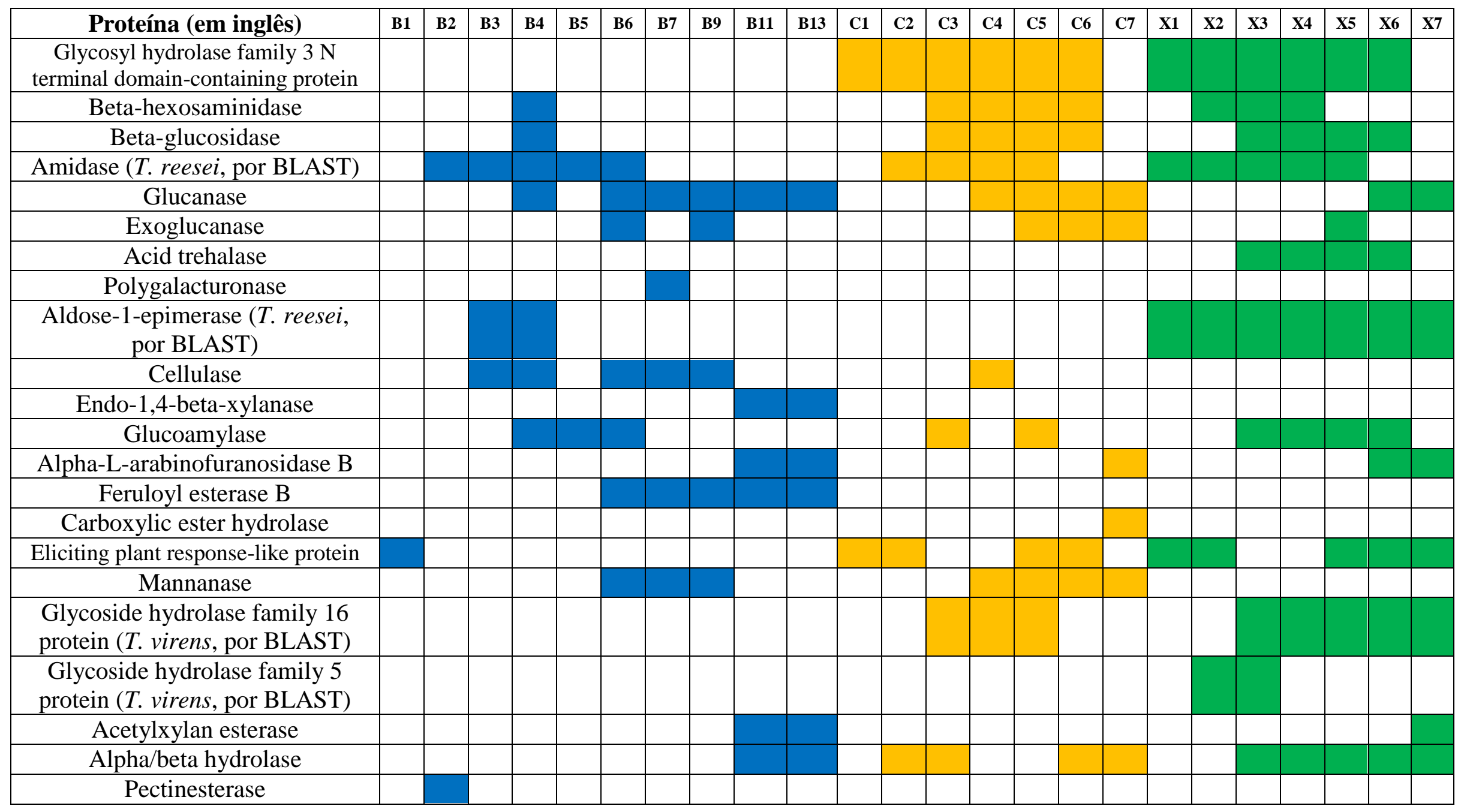


Já a função de $\mathrm{N}$-acetilglucosaminidase pode fazer sentido, como uma ação na remodelação da parede celular fúngica. É também possível que a enzima esteja realizando alguma função relacionada à interação do fungo com a planta, já que ela aparece aparentemente complexada com a cerato-platanina "Eliciting Plant Response-like protein" em oito das bandas. Ainda, talvez, a enzima tenha uma função similar à da escafoldina na organização de complexos quando o fungo é cultivado em meios definidos. A sinalização para a sua produção parece ser inibida por algum componente do bagaço de cana que não a celulose ou a xilana, já que a enzima não apareceu em nenhuma banda do cultivo em bagaço de cana.

Uma análise no InterPro (https://www.ebi.ac.uk/interpro/) (FINN et al., 2017; JONES et al., 2014) com a sequência da proteína, numa busca por domínios, identificou três deles (Figura 35). Além do domínio GH3 N-terminal que dá nome à proteína, também foram encontrados um domínio GH3 C-terminal e um domínio Fibronectina Tipo III-like. Este último é descrito como de função desconhecida, mas comumente associado a proteínas da família GH3.

Nos géis bidimensionais do cultivo em celulose, na Figura 23 e na Figura 24, e em xilana, na Figura 25 e na Figura 26, é possível ver uma forte linha horizontal numa altura próxima aos $87 \mathrm{kDa}$ correspondentes à massa da proteína. Isso sugere que ela esteja envolvida em diversos complexos, além dos analisados, nos cultivos em celulose e em xilana.

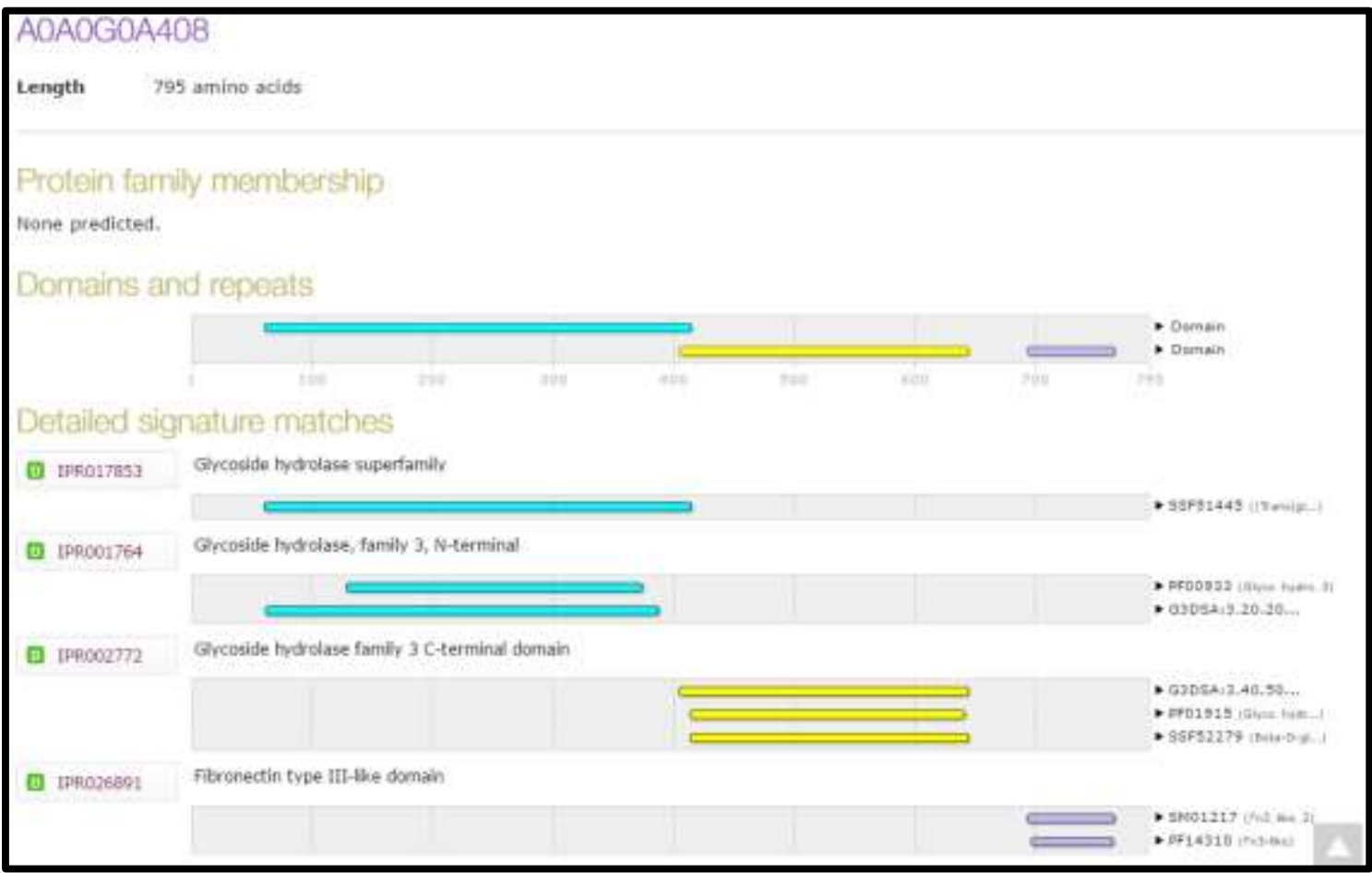

Figura 35. Análise no InterPro da sequência da proteína "Glycosyl hydrolase family $3 \mathrm{~N}$ terminal domain-containing protein" identificada no experimento, com identificação de três domínios.

As $\beta$-hexosaminidases fúngicas são capazes da hidrólise de resíduos de $\mathrm{N}$-acetil$\beta$-D-hexosamina em uma extremidade não-redutora de polissacarídeos de quitina. Essa característica é comum para fungos capazes de biocontrole, como os do gênero Trichoderma. Essas enzimas atuam sinergisticamente com as endoquitinases, que clivam 
a quitina nas porções internas. Para o fungo T. harzianum, um modelo de biocontrole no gênero, já são descritas mais de dez enzimas quitinolíticas (KOVACS et al., 2004).

As $\beta$-hexosaminidases do gênero Trichoderma são comumente secretadas, embora sua atividade intracelular seja ainda maior. Essas enzimas encontram-se na forma dimérica e, portanto, podem ter suas subunidades separadas em processos desnaturantes. Os genes para as $\beta$-hexosaminidases são positivamente regulados pela presença da glicosamina, um monômero da quitina (CHET et al., 2004). Sua presença no cultivo pode ter sido induzida pelo próprio fungo, pois ele já estava sendo cultivado há nove dias quando os secretomas foram obtidos, e já poderia estar havendo algum estresse causado pelo grande desenvolvimento micelial em conjunção com a redução na disponibilidade de fontes de carbono (DO VALE et al., 2012). Para esta enzima, a tendência de complexação também foi maior nos cultivos em xilana e celulose, só aparecendo em uma banda do bagaço de cana.

As $\beta$-glicosidases presentes, como já discutido, atuam no catabolismo de celulose. Curiosamente também estiveram presentes somente em uma banda do bagaço de cana e em quatro da celulose. Também foram identificadas $\beta$-glicosidases em quatro bandas do cultivo em xilana, o que indica que mesmo na ausência de celulose sua expressão pode ser induzida. Embora a celulose seja um indutor de celulases, acredita-se que as $\beta$ glicosidases sejam capazes de converter a celobiohidrolases em soforose por transglicosilação, e a soforose é o mais potente indutor de celulases em $T$. reesei. Estudos com $T$. reesei também mostraram que diferentes tipos de xilana induziram a expressão de genes para a expressão de celulases, o que pode explicar a presença das $\beta$-glicosidases nos cultivos com xilana (ARO; PAKULA; PENTTILÄ, 2005).

A amidase foi identificada por BLAST com $93,1 \%$ de homologia com a amidase de T. reesei. O InterPro também acusa um domínio Assinatura de Amidase (AS - Amidase Signature - IPR023631) na estrutura (Figura 36). A função desse tipo de enzima é de hidrolisar ligações amida $\left(\mathrm{CO}-\mathrm{NH}_{2}\right)$, podendo atuar em peptídeos, lipídeos e ésteres orgânicos (VALIÑA; MAZUMDER-SHIVAKUMAR; BRUICE, 2004). Por ser um tipo de enzima com mais de uma possível atuação, e já ter sido identificado por homologia, é difícil propor possíveis ações para ela nos complexos. Parece ser, também, uma proteína comum em complexos, pois apareceu em bandas nas três condições.

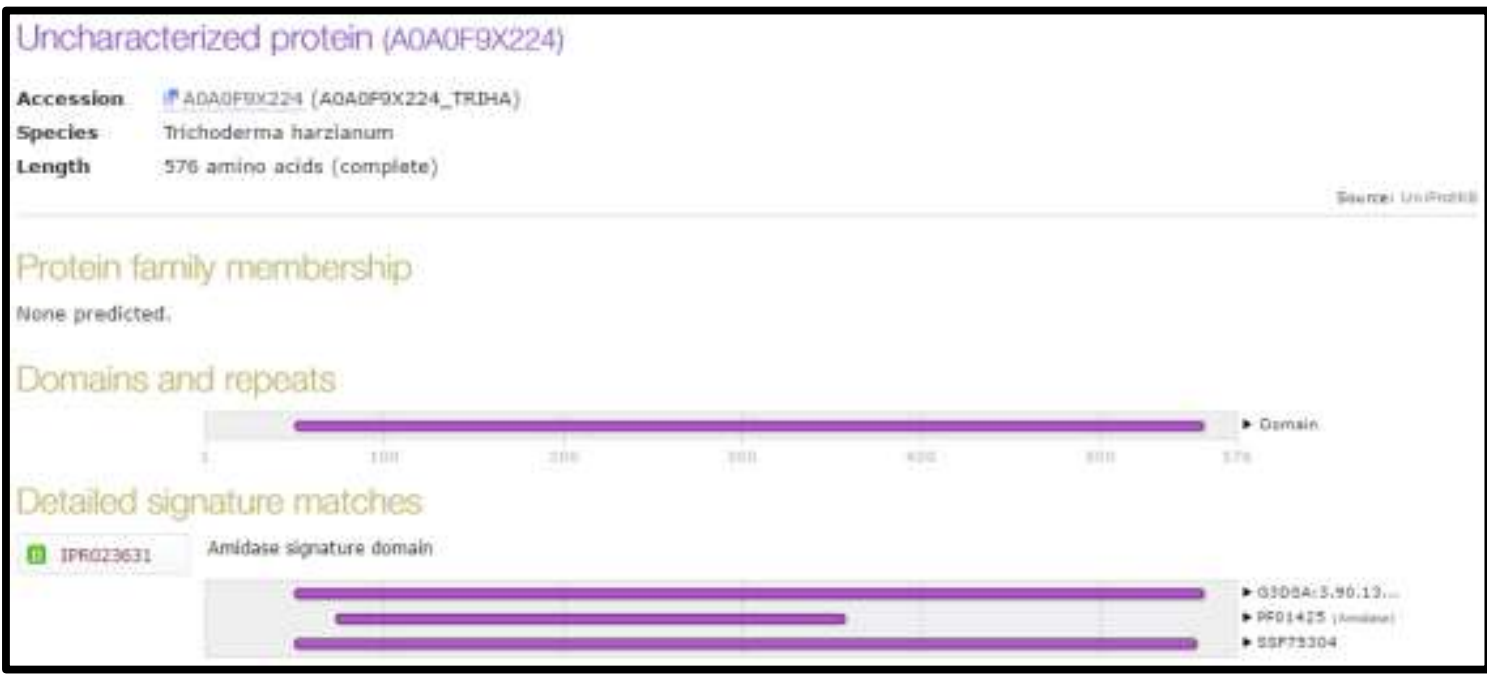

Figura 36. Análise no InterPro de uma proteína não-caracterizada que, por BLAST, tem 93,1\% de similaridade com a amidase de $T$. reesei. 
Glicanase é uma classificação que envolve enzimas capazes de hidrolisar ligações glicosídicas em polímeros de glicose por dois diferentes mecanismos, muitas vezes ocorrendo de forma sinérgica: exoglicanases, que clivam ligações nas extremidades do polímero, e endoglicanases, que clivam os polissacarídeos em sítios internos aleatórios. Como agente de biocontrole, o fungo $T$. harzianum é capaz de produzir $\beta$-glicanases para a degradação de 1,3- $\beta$-glicanos na parede celular de fungos. Também há fungos com celulose na parede celular de alguns fungos, como oomicetos. Essa produção é também associada à produção de quitinases para degradação de parede celular fúngica. Já é descrita a produção de 1,3- $\beta$-glicanases quando o $T$. harzianum é cultivado na presença de quitina (DE LA CRUZ et al., 1995; NORONHA; ULHOA, 1996).

Dentre as identificações, as diferentes enzimas cujo nome é só "Glucanase" tiveram todas "catabolismo de celulose" como descrição de processo biológico no UniProtKB, e "atividade hidrolítica" e "ligação a celulose" como função molecular no InterPro. Portanto, essas enzimas tiveram especificidade para as ligações glicosídicas $\beta$ 1,4 dos polímeros de celulose, no experimento. A exoglicanase 1 também tem atividade celulolítica descrita e revisada no Swiss-Prot, com capacidade para a liberação de celobiose das extremidades de celulose e celotetraose. Já a $\beta$-1,3-exoglicanase identificada é descrita como uma Glicosil Hidrolase da família 55, capaz de hidrolisar $1,3-\beta$-glicanos na parede celular de fungos.

Glicanases e exoglicanases apareceram em todos os cultivos, mas com mais frequência na presença da celulose e bagaço de cana que na presença de xilana. Isso provavelmente se deve à indução pela presença da celulose, nos dois primeiros casos, e pela presença de quitina do próprio fungo no cultivo com xilana. Também é possível que a xilana esteja participando em parte dessa indução por alguma via menos específica, já que o fungo não evoluiu convivendo com meios compostos só por xilana - a presença de xilana está sempre associada à presença de celulose.

A presença de quitinases como a 42 e 46 (com 42 e $46 \mathrm{kDa}$ de tamanho, respectivamente) também foi detectada, embora não com scores altos o bastante para aparecer na Tabela 5. Essas enzimas são importantes para atuar não só contra paredes celulares de outros fungos, mas também na própria parede celular em processos como a germinação de esporos e o crescimento e ramificação de hifas. Em culturas mais antigas, essas enzimas também realizam processos de autodigestão para reciclagem de hifas antigas (GRUBER; SEIDL-SEIBOTH, 2012).

A trealose, ou $\alpha$-D-glicopiranosil- $\alpha$-D-glicopiranosídeo, é um dissacarídeo muito presente na biomassa em decomposição, sendo uma fonte exógena importante de carbono para fungos filamentosos. Ela também é usada por eles intracelularmente como fonte de carbono, por exemplo, para a germinação de esporos. Outra importância dela é na anidrobiose, pois essa molécula é capaz de substituir a água na estabilização de bicamadas lipídicas (PARROU et al., 2005).

As trealases são as principais enzimas envolvidas no catabolismo da trealose, e podem ser classificadas em neutra (intracelular) ou ácida (extracelular) com base em seu pH ótimo de funcionamento. A secreção de trealase ácida por fungos filamentosos é muito importante para o aproveitamento da trealose da biomassa por meio da hidrólise em monômeros de glicose. Em alguns organismos, como Aspergillus nidulans, essa enzima só tem atividade como um dímero (PARROU et al., 2005).

Um estudo da competição entre T. harzianum e o fungo Phytophthora cinnamomi em solo autoclavado indicou, por análises de ação da trealase ácida, que o fungo $T$. 
harzianum é capaz de usar partes do micélio de P. cinnamomi como substrato (KELLEY; RODRIGUEZ-KABANA, 1976). Como as xilanas comerciais já vêm com um pouco de glicose na composição, é possível que o fato de haver nesse cultivo um pouco mais de glicose tenha favorecido um desenvolvimento de maior quantidade de micélio, o que foi observado visualmente (dados não mostrados). É possível que a secreção de trealase ácida somente no cultivo com xilana, identificada em quatro bandas do BN-PAGE, seja uma resposta ao estresse gerado nessa condição.

A pectina, o polissacarídeo mais complexo da parede celular primária vegetal, possui um esqueleto carbônico com monômeros de ácido $\alpha$-D-galacturônico (GalpA) de três tipos: homogalacturonana, ramnogalacturonana II e xilogalacturonana. Para a degradação da pectina, três tipos de enzimas podem ser utilizados: as pectina esterases, as poligalacturonases e as pectina liases. Destas, as duas primeiras foram identificadas com altos scores na Tabela 5. As poligalacturonases clivam as ligações glicosídicas $\alpha-1,4$ entre resíduos de ácido galacturônico não esterificados e já foram encontradas com altas especificidades em $T$. reesei e $T$. harzianum, podendo ser aplicadas em indústrias alimentícias. O "afrouxamento" da parede celular vegetal, por ação das poligalacturonases, é importante para permitir o subsequente acesso das celulases à celulose. (MARKOVIC; SLEZÁRIK; LABUDOVÁ, 1985; MOHAMED et al., 2006).

As pectina esterases, ou pectinesterases, por sua vez, catalisam a desesterificação da pectina ao longo da extensão do seu esqueleto carbônico. Após a ação das pectinesterases, a ação das poligalacturonases é facilitada (MARKOVIC; KOHN, 1984; MICHELI, 2001). Tanto a poligalacturonase quanto a pectina esterase foram identificadas somente em bandas provenientes do cultivo em bagaço de cana, uma vez que só nesse meio havia pectinas.

A aldose-1-epimerase foi identificada por BLAST com 84,0\% de homologia com a de $T$. reesei. No InterPro, foi determinada que a família da proteína é Aldose 1-/glicose6-fosfato 1-epimerase (Figura 37). Foram, ainda, encontrados dois domínios: domínio galactose mutarotase-like e domínio tipo glicosil hidrolase de ligação a carboidrato. A aldose-1-epimerase, ou mutarotase, é um tipo de enzima responsável pela interconversão anomérica (entre formas $\alpha$ e $\beta$ e vice-versa) da D-glicose e de outras aldoses. A glicose6-fosfato 1 epimerase, especificamente, catalisa essa interconversão em três diferentes aldoses. Essa especificidade ampla de substratos envolve a glicose-6-fosfato, galactose6-fosfato e manose-6-fosfato (GRAILLE et al., 2006).

$\mathrm{Na}$ sequência dessa proteína, especificamente, foram encontrados os domínios galactose mutarotase-like e tipo glicosil hidrolase de ligação a carboidrato. A proteína, presente em todas as bandas do cultivo em xilana e em duas do cultivo em bagaço-decana, pode estar funcionando como a região do domínio de ligação a carboidrato do complexo. Os géis da Figura 25 e da Figura 26 mostram uma grande linha horizontal numa altura próxima aos $47 \mathrm{kDa}$ da proteína, o que pode sugerir que os complexos nesse substrato se organizem em torno dessa proteína. 


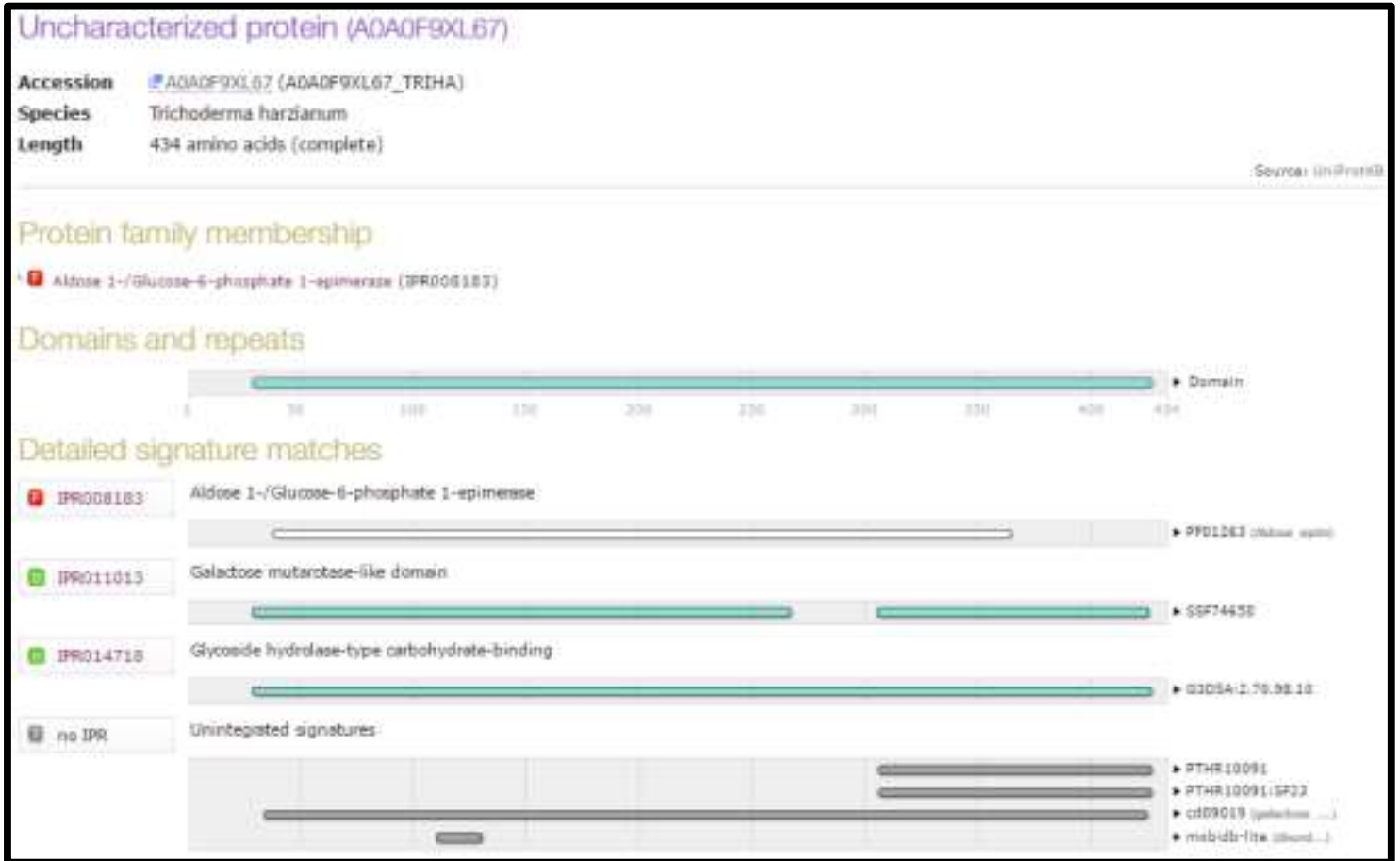

Figura 37. Análise no InterPro de uma proteína não-caracterizada que, por BLAST, tem $84,0 \%$ de similaridade com a aldose-1-epimerase de T. reesei. A família está indicada por $\mathrm{F}$, em vermelho, e os domínios por $\mathrm{D}$, em verde.

A ação das celulases já foi amplamente discutida nessa dissertação. A enzima descrita simplesmente como "celulase", nas tabelas de identificação, aparece como inferida por homologia no UniProtKB sem qualquer indicação de qual o tipo de celulase a que ela pertence. Sabe-se que foi a mesma identificação (mesmo Número de Acesso) e que foi uma das proteínas com mais alto score, figurando na Tabela 5. Essa enzima apareceu em várias bandas do cultivo em bagaço de cana, mas somente em uma banda do cultivo em celulose, sem aparecer nos cultivos em xilana. Por sua vez, a xilanase endo1,4- $\beta$-xilanase, responsável pela clivagem interna da xilana entre os monômeros de resíduos de D-xilose, só apareceu em duas bandas de mais baixa massa no cultivo com bagaço de cana, sem aparecer no cultivo com xilana.

Para a degradação do amido, são necessárias enzimas que têm ação hidrolítica sobre as ligações $\alpha$-glicosídicas do polímero. Dentre essas enzimas há as de ação tipo exo, ou seja, que atuam nas extremidades do polímero, como $\alpha$-glicosidases ou glicoamilases. As reações ocorrem pela ruptura da ligação entre o carbono anomérico de um resíduo de glicose e o oxigênio do outro. A diferença entre a ação das enzimas está no tipo de anômero do produto: as $\alpha$-glicosidases liberam $\alpha$-D-glicose, enquanto as glicoamilases liberam $\beta$-D-glicose (CHIBA, 1997). Houve presença de glicoamilases em bandas de todos os tipos de secretoma, provavelmente induzidas pela presença de glicose nos meios de cultivo.

Outra enzima presente nas identificações de maior score foi a $\alpha$-Larabinofuranosidase $B$, uma enzima que catalisa a hidrólise de ligações arabinofuranosídicas dos tipos $\alpha-1,2-, \alpha-1,3$ e $\alpha-1,5$ nas hemiceluloses que contêm arabinose, como a arabinoxilana e a L-arabinana (MIYANAGA et al., 2004). Essa enzima apareceu em bandas do cultivo com bagaço de cana e xilana, o que era esperado, mas também apareceu em uma das bandas de cultivo em celulose. 
A enzima feruloil esterase B, como mostrado na Figura 4, atua promovendo a formação e clivagem de ligações do tipo éster entre resíduos de ácido ferúlico e polissacarídeos como a xilana. A remoção do resíduo de ácido ferúlico favorece a ação das demais xilanases e a solubilização da xilana (FAZARY; JU, 2007; ZHANG et al., 2011). Os polímeros da parede celular vegetal costumam formar ligações cruzadas entre si, usualmente por meio do ácido ferúlico e do ácido p-cumárico. O objetivo dessa ligação cruzada, para a planta, é justamente aumentar sua resistência ao ataque de microrganismos (GARCIA-CONESA et al., 2004).

A análise da sequência da enzima feruloil esterase B no InterPro revelou dois domínios distintos: um domínio fúngico de ligação a celulose e um domínio de dobramento $\alpha / \beta$ hidrolase (Figura 38). Apesar do nome, o domínio de ligação a celulose está presente na estrutura tanto de celulases quanto de xilanases, ligado a um outro domínio o qual tem atividade catalítica. Embora os domínios de ligação a celulose não tenham atividade catalítica em si, eles modulam as atividades específicas das enzimas (GILKES et al., 1991). Já o domínio de dobramento $\alpha / \beta$ hidrolase é comum a várias enzimas hidrolíticas de diversas funções que divergiram de algum ancestral em comum. Esse domínio apresenta oito folhas- $\beta$ conectadas por $\alpha$-hélices (OLLIS et al., 1992). É possível que a presença desses dois domínios tão comuns a outras enzimas favoreça uma oligomerização para a formação de complexos, já que essa enzima aparece em diversas bandas no cultivo em bagaço de cana (mas não aparece nos outros dois cultivos).

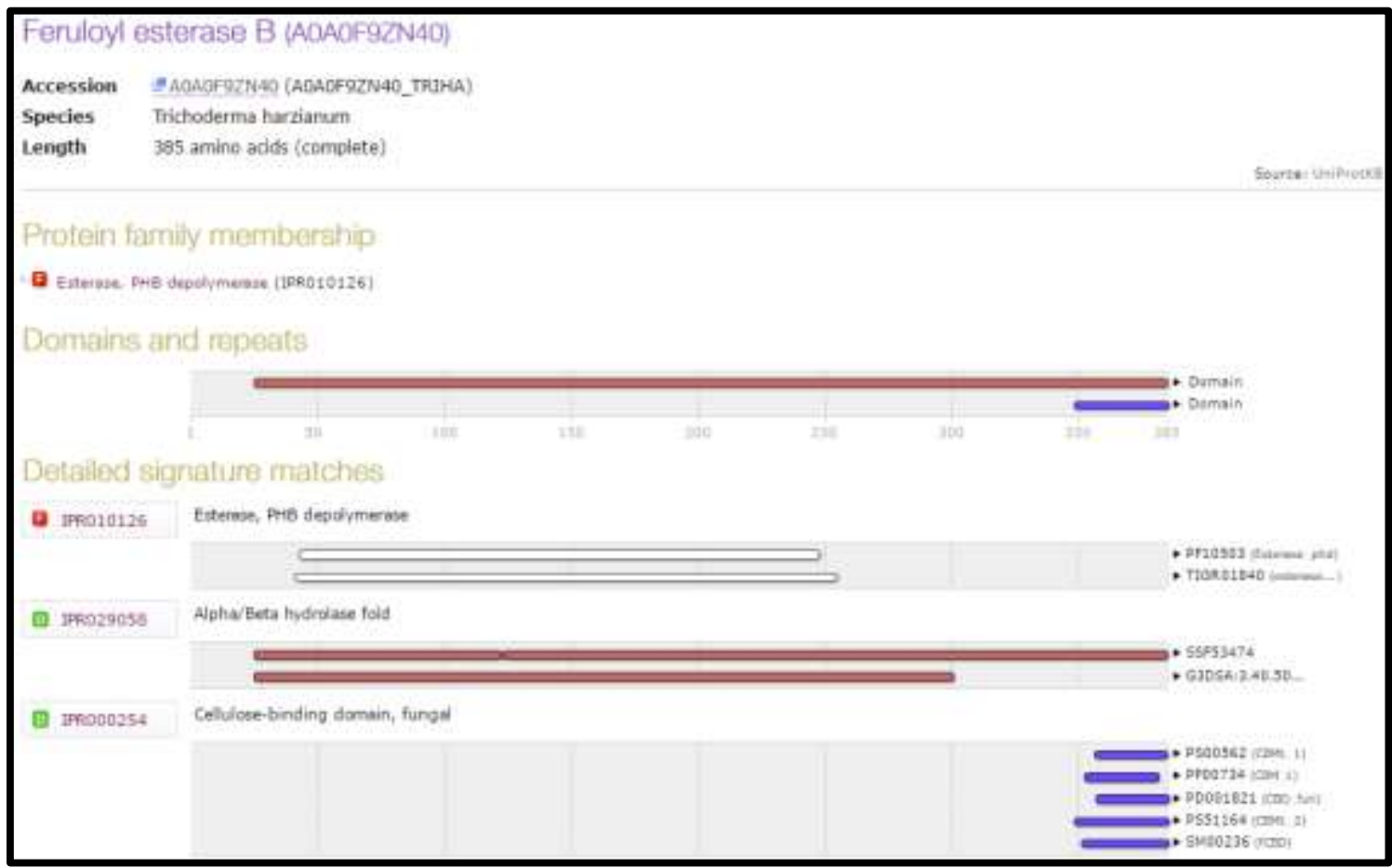

Figura 38. Análise no InterPro da sequência da proteína Feruloil Esterase B identificada no experimento, com identificação de dois domínios. A família está indicada por F, em vermelho, e os domínios por $\mathrm{D}$, em verde.

As feruloil esterases fazem parte de uma classe maior de enzimas pertencentes às $\alpha / \beta$ hidrolases, as éster carboxílico hidrolases. Essas enzimas podem ser classificadas em três categorias, A, B ou C, dependendo dos seus padrões de inibição. De acordo com o InterPro, a enzima identificada pertence ao tipo B, um grupo no qual estudos já indicaram 
que as proteína são evolutivamente relacionadas (MYERS; RICHMOND; OAKESHOTT, 1988). Muitas enzimas do tipo esterase têm ampla variedade de substratos, possivelmente para permitir o acesso a diferentes fontes de carbono. As ligações do tipo éster são comuns à estrutura dos carboxiésteres e lipídeos, ocorrendo ainda como modificações em polissacarídeos. As reações de hidrólise dessas ligações são facilmente reversíveis a depender da concentração dos reagentes, e como ésteres são importantes compostos na indústria alimentícia em compostos com sabor, os microrganismos produtores de esterases têm sido muito estudados (BORNSCHEUER, 2002; MCKAY, 1993).

$\mathrm{Na}$ parede celular vegetal, moléculas como xilana, pectina e lignina ocorrem naturalmente em formas esterificadas. Os microrganismos, portanto, precisam secretar esterases para remover resíduos metil, acetil e fenol. Enzimas como a pectinesterases, acetilxilanesterase e feruloil esterase, por exemplo, são éster carboxílico hidrolases secretadas por fungos para realizar esse papel (MCKAY, 1993). Em síntese, as esterases foram desenvolvidas ao longo da evolução para "raspar" as ramificações dos polissacarídeos de modo a permitir o acesso das enzimas que degradam a cadeia principal polissacarídica (WILLIAMSON; KROON; FAULDS, 1998).

Éster carboxílico esterases foram identificadas de forma mais específica em algumas bandas: B2 para pectinesterases, B11, B13 e X7 para acetilxilanesterase e B6-13 para feruloil esterase. Já na banda $\mathrm{C} 7$ foi identificada uma proteína de alto score de forma mais geral, como éster carboxílico hidrolase. A análise no InterPro não revelou nenhum domínio mais específico para essa proteína (Figura 39).

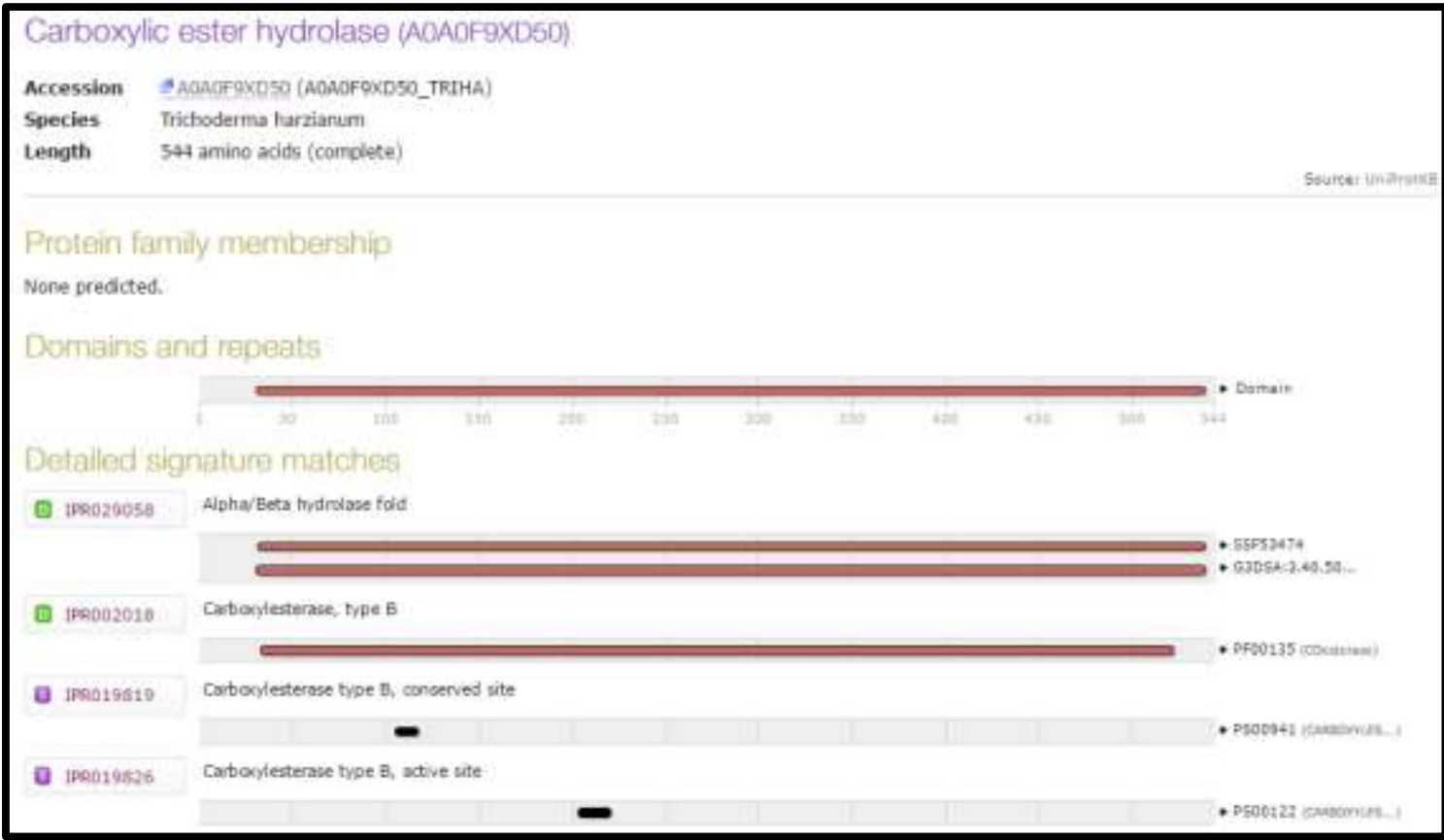

Figura 39. Análise no InterPro da sequência da proteína Éster Carboxílico Hidrolase identificada no experimento, com identificação de dois domínios. Os domínios estão indicados por $\mathrm{D}$, em verde, e os sítios por $\mathrm{S}$, em roxo.

A acetilxilanesterase, ou acetil xilana esterase, ainda não foi discutida nessa dissertação. Como dito nos parágrafos anteriores, ela também aparece na lista de proteína de mais alto score da Tabela 5 e tem como função permitir o acesso das xilanases à cadeia 
principal da xilana. Ela faz isso atuando sobre xilanas acetiladas e removendo os grupos acetil da cadeia principal, sendo portanto muito importante nos sistemas celulolíticos fúngicos (BIELY; PULS; SCHNEIDER, 1985).

No item 1.5) da Introdução foi discutida a importância do gênero Trichoderma na indução de resistência local e sistêmica (ISR) vegetal e o papel das cerato-plataninas nessa simbiose. Foi discutido o papel da Epl1 (Eliciting Plant Response-Like Protein 1) como um exemplo dessas proteínas e a sua capacidade de auto-organização em interfaces líquido/sólido formando monocamadas ordenadas, além da sua capacidade de se aderir a várias formas diferentes de quitina (BONAZZA et al., 2015; FRISCHMANN et al., 2013).

Essa proteína, em T. harzianum, também já foi descrita como tendo importância no auto reconhecimento do fungo, na regulação da expressão de genes relacionados ao micoparasitismo, na modulação do enrolamento das hifas micoparasíticas e na regulação da indução de genes relacionados a defesa nas plantas com que o fungo faz simbiose. Em um estudo com uma cepa mutada para não produzir essa proteína, os autores sugeriram que ela possui uma importância fundamental para a adaptação do fungo ao seu ambiente, especialmente na interação com patógenos fúngicos e com plantas (GOMES et al., 2015).

A Epl1 foi identificada em bandas do BN-PAGE nas três fontes de carbono, principalmente nos cultivos em celulose e xilana. É curioso encontrar uma proteína com uma função tão diferente, de simbiose, da das outras enzimas encontradas, de hidrólise da parede celular. A capacidade descrita de auto-organização dessa proteína pode ser uma pista para a sua função no complexo, possivelmente agindo na organização dele de forma similar à escafoldina. Sua capacidade de ligação à quitina, associada ao fato de que a enzima esteve presente em bandas com quitinases como glicanases, $\beta$-hexosaminidases e a "Glycosyl hydrolase family $3 \mathrm{~N}$ terminal domain-containing protein", pode sugerir ainda que os complexos de que ela faça parte tenham como função principal não a bioconversão de resíduos lignocelulósicos, mas o biocontrole no micoparasitismo.

Com massa de aproximadamente $14 \mathrm{kDa}$, a Epl1 esteve presente nas bandas $\mathrm{C} 1$, B1 e X1. Nos géis bidimensionais BN/SDS-PAGE, essas bandas não se decompuseram em um perfil complexo de bandas, mas geraram um spot na altura correspondente à massa da Epl1. Isso parece sugerir que esse complexo de alta massa é um homômero dessa proteína, que é capaz de se autoorganizar.

As mananas e heteromananas compõem até $10 \%$ da fração hemicelulósica da biomassa lignocelulósica, e são hidrolisadas por mananases. Mananas são polímeros de manose, enquanto heteromananas são compostas de dois ou mais diferentes monômeros (além da manose, há galactose ou glicose). As mananases hidrolisam ligações $\beta$-D-1,4 entre resíduos de manopiranosídeo. Além da hidrólise, essas enzimas são capazes também de realizar transglicosilações, formando novos glicoconjugados. As mananases podem ser classificadas em endo-1,4- $\beta$-mananases, que clivam as mananas internamente; $\beta$ manosidases, que liberam manose das extremidades; $\beta$-glicosidases, que clivam ligações glicosídicas entre manose e glicose; e enzimas que clivam cadeias laterais de galactose como a $\alpha$-galactosidase e as acetil manana esterases (DHAWAN; KAUR, 2007; SONI et al., 2016).

Na parede celular vegetal, as mananas e heteromananas se situam entre a lignina e as fibras de celulose, por vezes formando ligações covalentes com a lignina e ligações de hidrogênio com a celulose. Essa disposição das mananas e heteromananas permite uma manutenção da integridade da parede celular e protege as fibras da degradação das 
celulases. Portanto, a degradação desses polissacarídeos é importante para permitir o acesso das celulases à celulose. Os fungos T. reesei e T. harzianum são descritos como importantes produtores de mananases (DHAWAN; KAUR, 2007).

Foram identificadas mananases em bandas dos cultivos em celulose e em bagaço de cana, mas não no cultivo em xilana. Todas elas tinham o mesmo Número de Acesso do UniProtKB e eram descritas apenas como "mananase" com domínios glicosil hidrolase, portanto não foi possível determinar qual o tipo de mananase presente. A proteína foi inferida por homologia, de acordo com o UniProtKB.

Proteínas descritas apenas como Glicosil Hidrolases das famílias 5 e 16 foram identificadas por BLAST com 95,9 e $91,5 \%$ de homologia com T. virens, respectivamente. As GHs foram estudadas por similaridade de sequência e divididas em 85 famílias, uma classificação que é utilizada pelo site CAZy (http://www.cazy.org/) (DAVIES; HENRISSAT, 1995; HENRISSAT et al., 1995).

A análise no InterPro da primeira delas mostra que a sequência da primeira corresponde, na verdade, à da família 30 de GHs (Figura 40). Realmente, trabalhos recentes reclassificaram diversos grupos pertencentes à família 5 de GHs para a família 30 de GHs por similaridades de sequência (ST JOHN; GONZÁLEZ; POZHARSKI, 2010). A família 30 de GHs envolve muitas xilanases previamente pertencentes à família 5 , uma família de endoglicanases. Muitas endo-1,4- $\beta$-xilanases pertencentes a essa família já foram descritas com sequência diversa das da família 5 (BIELY et al., 2014; ST JOHN et al., 2011; ST JOHN; GONZÁLEZ; POZHARSKI, 2010). No experimento, essas enzimas foram encontradas somente em bandas provenientes do cultivo em xilana, o que é coerente. Não foi possível, no entanto, determinar no InterPro qual o tipo exato da enzima identificada.

A família 16 de GHs envolve enzimas capazes de hidrolisar ligações glicosídicas dos tipos $\beta-1,3$ e $\beta-1,4$ em glicanos e galactanos. Muitas enzimas dessa família têm ação de transglicosilase, dentre elas as enzimas $\mathrm{Crh} 1$ e $\mathrm{Crh} 2$ de leveduras. Essas enzimas atuam sobre a ligação covalente entre a quitina e um $\beta$-1,6-glicano em leveduras, estando ancorada a lipídeos do tipo glicosilfosfatidilinositol (GPI) na parede celular do fungo (CABIB et al., 2007). O trabalho prévio a respeito de complexos multienzimáticos em $T$. harzianum cultivado em bagaço de cana encontrou uma $\beta$-glicosidase ancorada a GPI homóloga à de $T$. reesei, e hipotetizou que em complexos essa enzima facilite o contato próximo da parede celular fúngica com a biomassa vegetal (DA SILVA et al., 2012).

A análise no InterPro da enzima identificada em bandas no cultivo em xilana e em celulose indicou que ela é um homólogo da enzima Crh1 (Figura 41). É possível que a enzima, em T. harzianum, não esteja na parede celular e seja secretada. Outra possibilidade é que ela esteja envolvida na formação e secreção dos complexos a que pertence, se destacando da parede celular em conjunto com as outras proteínas. A coleta de secretomas não envolveu métodos para a solubilização de proteínas de membrana, e essa proteína foi uma das proteínas de maior score do experimento, figurando na Tabela 5 .

Para concluir a análise das proteínas da Tabela 5 , há várias identificações de $\alpha / \beta$ hidrolase com um mesmo número de acesso. É uma proteína predita, com um nome genérico que descreve apenas seu dobramento do tipo $\alpha / \beta$ hidrolase, discutido no parágrafo a respeito da feruloil esterase $\mathrm{B}$. 


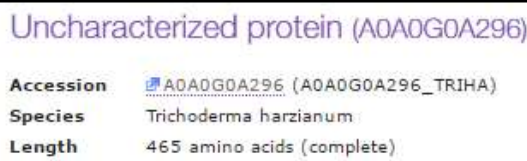

Protein family membership

Q Glycoside hydrolase family 30 (IPR001139)

Domains and repeats

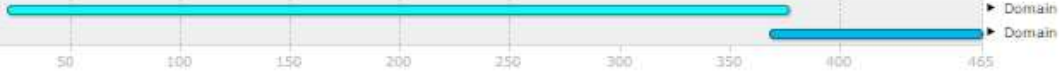

Detailed signature matches

G IPR001139

D. IPR017853

Glycoside hydrolase superfamily

D. IPR013781

Glycoside hydrolase, catalytic domain

D. IPR033453 Glycosyl hydrolase family 30, TIM-barrel domain

Di IPR013780 Glycosyl hydrolase, all-beta

D. IPR 033452

Glycosyl hydrolase family 30 , beta sandwich domain

Figura 40. Análise no InterPro de uma proteína não-caracterizada que, por BLAST, tem 95,9\% de similaridade com a família 5 de Glicosil Hidrolases de T. virens. A família está indicada por $\mathrm{F}$, em vermelho, e os domínios por $\mathrm{D}$, em verde.

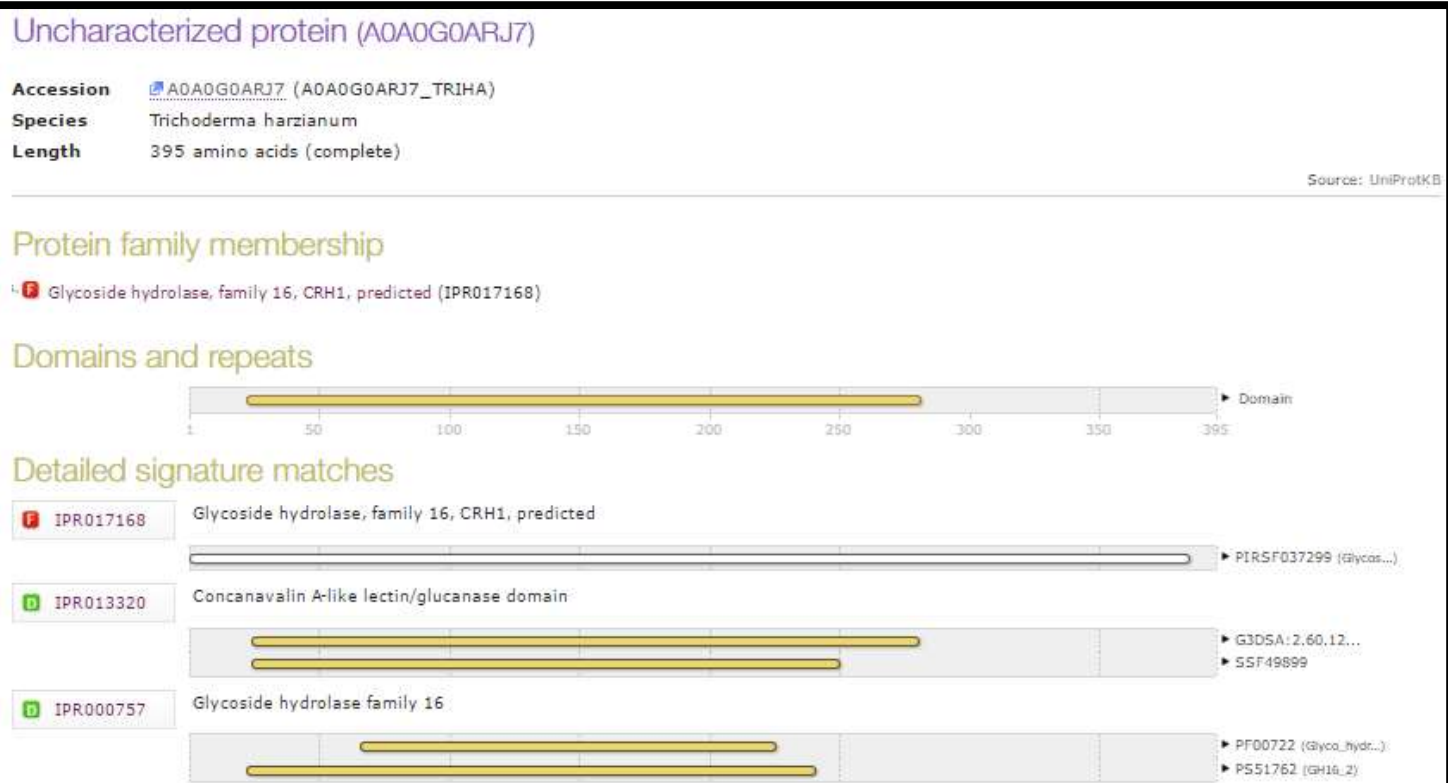

Figura 41. Análise no InterPro de uma proteína não-caracterizada que, por BLAST, tem 91,5\% de similaridade com a família 16 de Glicosil Hidrolases de T. virens. A família está indicada por $\mathrm{F}$, em vermelho, e os domínios por $\mathrm{D}$, em verde. 


\section{6) Conclusões}

A presente dissertação atingiu algumas conclusões relacionadas aos objetivos propostos e outras que surgiram na interpretação de dados. Mais uma vez o secretoma do fungo T. harzianum foi investigado por meio de técnicas proteômicas como forma de exploração da sua capacidade de degradação da biomassa lignocelulósica. O diferencial do presente estudo, no entanto, foi a realização de uma separação eletroforética nativa de proteínas anteriormente à identificação por espectrometria de massa bottom-up, permitindo uma análise proteômica shotgun de misturas menos complexas de proteínas nos secretomas.

Esse desenho experimental permitiu a detecção de complexos proteicos nos secretomas do fungo quando cultivado em três diferentes substratos: bagaço de cana, celulose e xilana. No entanto, os complexos não puderam ser caracterizados de forma definitiva devido a dois principais fatores. Em primeiro lugar, limitações inerentes ao uso do LC-MS/MS em análises do tipo shotgun, especialmente com relação à confiança das identificações e à presença de falsos positivos. As discrepâncias nas massas das proteínas identificadas quando comparadas às massas estimadas das bandas no BN-PAGE, ainda que haja um erro de cerca de $20 \%$ nas estimativas, se mostraram muito elevadas. E em segundo lugar, devido a uma preocupação com a possibilidade de sobreposições de bandas que é sempre um risco nas eletroforeses unidimensionais, risco o qual foi potencializado pelo uso do critério "bandas intensas" na seleção de bandas para análise. As discrepâncias de massas na análise também são indicativos da presença desse risco.

Ainda que as caracterizações de complexos individuais não tenham sido possíveis, no entanto, a decomposição das bandas nativas nos géis bidimensionais BN/SDS, em conjunto com a presença de diversas proteínas com identificação confiável nas bandas, mostrou não só que há a presença de complexos nas três condições, mas também que a complexação de proteínas é uma regra, e não uma exceção, nesses secretomas. Resta, no entanto, saber se esses complexos são funcionais. Para o restante das análises, foram consideradas proteínas com identificações mais confiáveis e acrescentou-se a elas a característica "presente em complexos proteicos no secretoma de T. harzianum", mesmo que não tenha sido possível dizer com confiança todas as proteínas que a acompanhavam nos complexos.

Pela composição das bandas, levando em conta proteínas de identificação mais confiável, foi demonstrado que a presença de determinadas proteínas em complexos é dependente das fontes de carbono. A presença de algumas proteínas em complexos, como a "Glycosyl hydrolase family $3 \mathrm{~N}$ terminal domain-containing protein" em quase todas as bandas de celulose e xilana, a aldose-1-epimerase em todas as bandas de xilana e duas bandas do bagaço, a feruloil esterase B somente em bandas de bagaço de cana, amidases em quase todas as bandas e, curiosamente, a proteína não-CAZima "Eliciting plant response-like protein" em complexos de todos os tipos levanta hipóteses para a presença de proteínas organizadoras de complexos, talvez com função análoga à das escafoldina nos celulossomas. 


\section{7) Perspectivas}

A Ciência trabalha com tentativas e erros, hipóteses e testes, modelos e desenhos experimentais. As conclusões do experimento são muito importantes para a reformulação de hipóteses e dos desenhos experimentais, visando sempre resultados mais precisos e confiáveis. O desenho experimental, apesar de adequado para a realização dos objetivos, não permitiu análises mais aprofundadas e confiáveis para a determinação da composição de complexos específicos devido às diversas preocupações já discutidas. Os trabalhos do laboratório que já foram publicados utilizando a identificação de bandas do 1D-BNPAGE com LC-MS/MS terão, portanto, que ser reinterpretados. Os trabalhos futuros de nosso laboratório com complexos proteicos precisarão, portanto, ter um novo desenho experimental.

O primeiro passo a ser realizado para atingir esses objetivos com maior confiança é a melhor separação e purificação de complexos. Para isso, técnicas como o GELFrEE, ultracentrifugação, cromatografia e 2-DE nativo já estão em processo de implementação no Laboratório de Bioquímica e Química de Proteínas em colaboração com o Laboratório de Enzimologia da Universidade de Brasília. Técnicas de imunoprecipitação (pull down) também poderão vir a ser implementadas usando como iscas as proteínas que aparecem nas tabelas apresentadas nesse trabalho, em especial as que aparecem em todos os secretomas. Possivelmente, essas técnicas deverão ser empregadas em conjunto para aumentar o grau de separação dos complexos. Dessa forma, será possível a decomposição dos complexos com uma preocupação bem menor com relação ao risco de sobreposições, elevando a confiabilidade das análises.

Com os complexos decompostos de forma mais confiável, o próximo passo é a identificação das subunidades individualmente, separadas em gel desnaturante, por LCMS/MS ou MALDI-TOF/TOF. A identificação de subunidades, ao invés do complexo inteiro, elevará a confiança das identificações por fugir dos riscos inerentes à análise shotgun de misturas complexas, como identificações parciais e falsos positivos. As proteínas podem ser identificadas por PMF e por sequenciamento de novo dos peptídeos na espectrometria em tandem, com comparação das massas das proteínas identificadas com as estimativas de massa em gel para validação das identificações.

A identificação das subunidades dos géis bidimensionais realizados no presente trabalho também será realizada, para verificar se a identificação das subunidades individuais corresponderá à massa estimada das bandas do BN-PAGE, permitindo a descrição de complexos específicos.

Outra perspectiva é a realização de ensaios de atividade enzimática dos complexos isolados nativos em gel (zimogramas) e em solução, para determinar se são funcionais e se a presença das proteínas em complexos garante maior eficiência que a sinergia das mesmas enzimas quando livres. Também é importante verificar se a atividade de uma subunidade específica é maior quando essa proteína faz parte de um complexo que quando ela está livre no meio.

Com os complexos nativos isolados, também é possível realizar análises biofísicas como fluorescência, dicroísmo circular e espalhamento de luz dinâmico, além de análises de crosslink por espectrometria de massa, para determinar a estrutura dos complexos.

Variações na metodologia, como o cultivo a partir de inóculo de micélio ao invés de esporos (para evitar a presença de proteínas relacionadas à esporulação) e a 
ultrafiltração dos secretomas com membranas com altos cutoffs (por exemplo, acima de $100 \mathrm{kDa}$ ) para enriquecer o secretoma para complexos também deverão ser realizadas. A liofilização dos secretomas também deverá ser evitada no futuro, para reduzir os riscos de ocorrer a formação de alguns complexos que não estavam originalmente no secretoma.

A deglicosilação dos secretomas, antes das separações eletroforéticas, poderá ser testada para verificar se há redução na complexidade dos perfis eletroforéticos, embora haja o risco de que os complexos se desfaçam devido a instabilidades estruturais.

Embora a identificação shotgun LC-MS/MS das proteínas das bandas do BNPAGE não seja ideal, pelos motivos já descritos nesse trabalho, experimentos de deglicosilação química ou enzimática podem ser realizados após a digestão das proteínas das bandas para permitir um aumento na cobertura das identificações (as proteínas do secretoma de $T$. harzianum são descritas como altamente glicosiladas), consequentemente elevando a confiabilidade das identificações. 


\section{8) Material Suplementar - Tabelas de Identificação}

Tabela 6. Resultado das identificações das proteínas da banda B1 do BN-PAGE.

\begin{tabular}{|c|c|c|c|c|c|c|c|}
\hline Número de Acesso & Score & $\begin{array}{c}\text { Cobertura } \\
(\boldsymbol{\%})\end{array}$ & \# Peptídeos & $\begin{array}{c}\text { \# Peptídeos } \\
\text { Únicos }\end{array}$ & PTMs & $\begin{array}{c}\text { Massa } \\
\text { Média (Da) }\end{array}$ & Descrição (em inglês) \\
\hline G8FPZ8 & 124,49 & 18 & 3 & 3 & Sim & 14389 & Eliciting plant response-like protein \\
\hline A0A0F9XP97 & 87,73 & 7 & 2 & 2 & Não & 41622 & Actin \\
\hline A0A0F9WYH5 & 76,64 & 4 & 1 & 1 & Não & 45007 & Cellulase \\
\hline
\end{tabular}

Tabela 7. Resultado das identificações das proteínas da banda B2 do BN-PAGE.

\begin{tabular}{|c|c|c|c|c|c|c|c|}
\hline Número de Acesso & Score & $\begin{array}{c}\text { Cobertura } \\
(\boldsymbol{\%})\end{array}$ & \# Peptídeos & $\begin{array}{c}\text { \# Peptídeos } \\
\text { Únicos }\end{array}$ & PTMs & $\begin{array}{c}\text { Massa } \\
\text { Média (Da) }\end{array}$ & Descrição (em inglês) \\
\hline A0A0F9XHS8 & 152,55 & 19 & 8 & 8 & Sim & 34506 & Pectinesterase \\
\hline A0A0F9Y5T3 & 81,40 & 7 & 2 & 2 & Sim & 36156 & $\begin{array}{c}\text { Glyceraldehyde-3-phosphate } \\
\text { dehydrogenase }\end{array}$ \\
\hline A0A0F9X224 & 74,49 & 3 & 2 & 2 & Sim & 62637 & $\begin{array}{c}\text { Uncharacterized protein (por BLAST: } \\
\text { Amidase / T. reesei com 93,1\% de } \\
\text { identidade) }\end{array}$ \\
\hline G8FPZ8 & 59,17 & 10 & 1 & 1 & Não & 14389 & Eliciting plant response-like protein \\
\hline A0A0F9WYH5 & 52,35 & 4 & 1 & 1 & Sim & 45007 & Cellulase \\
\hline A0A0F9Y3W7 & 50,83 & 2 & 1 & 1 & Sim & 41830 & $\begin{array}{c}\text { Uncharacterized protein (por BLAST: } \\
\text { ECM,4\% de identidade e Cell wall protein } \\
\text { / T. reesei com 85,2\% de identidade) }\end{array}$ \\
\hline A0A0F9Y0G5 & 48,73 & 1 & 1 & 1 & Não & 140960 & Cel74a \\
\hline A0A0S1VWD2 & 45,82 & 31 & 1 & 1 & Não & 3322 & Actin (Fragment) \\
\hline A0A0F9XP97 & 45,82 & 3 & 1 & 1 & Não & 41622 & Actin \\
\hline
\end{tabular}




\begin{tabular}{|c|c|c|c|c|c|c|c|}
\hline A0A0F9X878 & 42,25 & 1 & 1 & 1 & Sim & 166523 & WSC domain-containing protein \\
\hline A0A0F9XMI8 & 40,07 & 2 & 1 & 1 & Não & 35711 & Glycosylhydrolase family 61-2 \\
\hline A0A0F9XRV0 & 39,68 & 1 & 1 & 1 & Não & 78113 & Chaperonin GroL \\
\hline A0A0F9XL67 & 38,65 & 2 & 1 & 1 & Sim & 47504 & $\begin{array}{c}\text { Uncharacterized protein (por BLAST: } \\
\text { Aldose-1-epimerase / T. reesei com } \\
84,0 \% \text { de identidade) }\end{array}$ \\
\hline A0A0G0A0N0 & 29,57 & 1 & 1 & 1 & Não & 96867 & Ubiquitin thiolesterase \\
\hline A0A0F9Z848 & 27,91 & 1 & 1 & 1 & Não & 97705 & Trehalose 6-phosphate synthase \\
\hline
\end{tabular}

Tabela 8. Resultado das identificações das proteínas da banda B3 do BN-PAGE.

\begin{tabular}{|c|c|c|c|c|c|c|c|}
\hline Número de Acesso & Score & $\begin{array}{c}\text { Cobertura } \\
(\%)\end{array}$ & \# Peptídeos & $\begin{array}{l}\text { \# Peptídeos } \\
\text { Únicos }\end{array}$ & PTMs & $\begin{array}{c}\text { Massa } \\
\text { Média (Da) }\end{array}$ & Descrição (em inglês) \\
\hline A0A0F9WYH5 & 205,46 & 10 & 11 & 10 & Sim & 45007 & Cellulase \\
\hline A0A0F9X224 & 143,08 & 10 & 5 & 5 & Sim & 62637 & $\begin{array}{c}\text { Uncharacterized protein (por BLAST: } \\
\text { Amidase / T. reesei com } 93,1 \% \text { de } \\
\text { identidade) }\end{array}$ \\
\hline A0A0F9XL67 & 115,71 & 7 & 3 & 3 & Sim & 47504 & $\begin{array}{c}\text { Uncharacterized protein (por BLAST: } \\
\text { Aldose-1-epimerase / T. reesei com } \\
84,5 \% \text { de identidade) }\end{array}$ \\
\hline A0A0F9Y5T3 & 82,42 & 7 & 2 & 2 & Sim & 36156 & $\begin{array}{l}\text { Glyceraldehyde-3-phosphate } \\
\text { dehydrogenase }\end{array}$ \\
\hline A0A0F9Y0G5 & 78,97 & 2 & 2 & 2 & Sim & 140960 & Cel74a \\
\hline A0A0F9XMI8 & 54,13 & 2 & 1 & 1 & Não & 35711 & Glycosylhydrolase family $61-2$ \\
\hline A0A0F9Y3W7 & 52,31 & 2 & 1 & 1 & Não & 41830 & $\begin{array}{l}\text { Uncharacterized protein (por BLAST: } \\
\text { ECM33-like protein / T. reesei com } \\
\text { 86,4\% de identidade e Cell wall protein } \\
\text { / T. reesei com } 85,2 \% \text { de identidade) }\end{array}$ \\
\hline G8FPZ8 & 50,81 & 10 & 1 & 1 & Não & 14389 & Eliciting plant response-like protein \\
\hline
\end{tabular}




\begin{tabular}{|c|c|c|c|c|c|c|c|}
\hline A0A0F9XF89 & 50,51 & 1 & 1 & 1 & Não & 83087 & $\begin{array}{c}\text { Uncharacterized protein (por BLAST: } \\
\text { Glycoside hydrolase family 55 protein / } \\
\text { T. virens com 95,6\% de identidade) }\end{array}$ \\
\hline A0A0G0A3D5 & 46,51 & 6 & 1 & 1 & Não & 17578 & Ubiquitin-40S ribosomal protein S27a \\
\hline H9BVC3 & 46,51 & 3 & 1 & 1 & Não & 29611 & Ubiquitin (Fragment) \\
\hline
\end{tabular}

Tabela 9. Resultado das identificações das proteínas da banda B4 do BN-PAGE.

\begin{tabular}{|c|c|c|c|c|c|c|c|}
\hline Número de Acesso & Score & $\begin{array}{c}\text { Cobertura } \\
(\%)\end{array}$ & \# Peptídeos & $\begin{array}{c}\text { \# Peptídeos } \\
\text { Unicos }\end{array}$ & PTMs & $\begin{array}{c}\text { Massa } \\
\text { Média (Da) }\end{array}$ & Descrição (em inglês) \\
\hline A0A0F9X224 & 177,37 & 14 & 7 & 7 & Sim & 62637 & $\begin{array}{c}\text { Uncharacterized protein (por BLAST: } \\
\text { Amidase / T. reesei com 93,1\% de } \\
\text { identidade) }\end{array}$ \\
\hline P87258 & 143,45 & 9 & 5 & 5 & Sim & 64534 & Beta-hexosaminidase \\
\hline A0A0F9WYH5 & 128,64 & 6 & 4 & 4 & Sim & 45007 & Cellulase \\
\hline A0A0F9XMI8 & 121,17 & 7 & 6 & 6 & Sim & 35711 & Glycosylhydrolase family 61-2 \\
\hline A0A0F9Y0Z9 & 98,05 & 3 & 1 & 1 & Não & 51420 & Alpha-L-arabinofuranosidase \\
\hline A0A0F9XL67 & 94,70 & 6 & 3 & 3 & Sim & 47504 & $\begin{array}{c}\text { Uncharacterized protein (por BLAST: } \\
\text { Aldose-1-epimerase / T. reesei com } \\
84,0 \% \text { de identidade) }\end{array}$ \\
\hline A0A0F9ZH76 & 92,82 & 3 & 2 & 2 & Sim & 79362 & Purple acid phosphatase \\
\hline Q599K8 & 87,76 & 5 & 3 & 3 & Não & 66255 & Glucoamylase \\
\hline A0A0G0A7Y5 & 87,76 & 4 & 3 & 3 & Não & 69967 & Glucoamylase \\
\hline A0A0F9Y3W7 & 82,45 & 4 & 2 & 2 & Sim & 41830 & $\begin{array}{c}\text { Uncharacterized protein (por BLAST: } \\
\text { ECM33-like protein / T. reesei com } \\
86,4 \% \text { de identidade e Cell wall protein } \\
\text { / Teesei com 85,2\% de identidade) }\end{array}$ \\
\hline H9BBE8 & 74,70 & 3 & 2 & & & & Glucanase \\
\hline A0A0F9X2V9 & 74,70 & 3 & 2 & 2 & Sim & 53003 & Glucanase \\
\hline A0A0F9Y0X0 & 65,57 & 2 & 2 & 2 & Sim & 92721 & Beta-glucosidase \\
\hline
\end{tabular}




\begin{tabular}{|c|c|c|c|c|c|c|c|}
\hline A0A0G0AEM7 & 64,75 & 4 & 1 & 1 & Não & 49388 & Glucanase \\
\hline A0A0F9Y0G5 & 61,82 & 1 & 1 & 1 & Não & 140960 & Cel74a \\
\hline A0A0G0A408 & 55,92 & 1 & 1 & 1 & Sim & 86623 & $\begin{array}{c}\text { Glycosyl hydrolase family 3 N terminal } \\
\text { domain-containing protein }\end{array}$ \\
\hline G8FPZ8 & 54,21 & 10 & 1 & 1 & Não & 14389 & Eliciting plant response-like protein \\
\hline A0A0S1VWD2 & 53,25 & 31 & 1 & 1 & Não & 3322 & Actin (Fragment) \\
\hline A0A0F9XP97 & 53,25 & 3 & 1 & 1 & Não & 41622 & Actin \\
\hline A0A0G0AGG8 & 41,16 & 2 & 1 & 1 & Sim & 46231 & Mannanase \\
\hline M4T2Q5 & 41,16 & 2 & 1 & 1 & Sim & 47164 & Man5A \\
\hline A0A0G0AN43 & 40,20 & 2 & 1 & 1 & Sim & 51955 & Murein transglycosylase \\
\hline A0A0F9X878 & 35,65 & 1 & 1 & 1 & Sim & 166523 & WSC domain-containing protein \\
\hline
\end{tabular}

Tabela 10. Resultado das identificações das proteínas da banda B5 do BN-PAGE.

\begin{tabular}{|c|c|c|c|c|c|c|c|}
\hline Número de Acesso & Score & $\begin{array}{c}\text { Cobertura } \\
(\%)\end{array}$ & \# Peptídeos & $\begin{array}{l}\text { \# Peptídeos } \\
\text { Únicos }\end{array}$ & PTMs & $\begin{array}{c}\text { Massa } \\
\text { Média (Da) }\end{array}$ & Descrição (em inglês) \\
\hline Q599K8 & 99,27 & 6 & 5 & 5 & Sim & 66255 & Glucoamylase \\
\hline A0A0G0A7Y5 & 99,27 & 5 & 5 & 5 & Sim & 69967 & Glucoamylase \\
\hline A0A0F9X224 & 89,43 & 6 & 3 & 3 & Sim & 62637 & $\begin{array}{c}\text { Uncharacterized protein (por BLAST: } \\
\text { Amidase / T. reesei com } 93,1 \% \text { de } \\
\text { identidade) }\end{array}$ \\
\hline A0A0F9Y3W7 & 64,42 & 4 & 2 & 2 & Sim & 41830 & $\begin{array}{l}\text { Uncharacterized protein (por BLAST: } \\
\text { ECM33-like protein / T. reesei com } \\
\text { 86,4\% de identidade e Cell wall protein } \\
\text { / T. reesei com } 85,2 \% \text { de identidade) }\end{array}$ \\
\hline G8FPZ8 & 64,27 & 10 & 1 & 1 & Não & 14389 & Eliciting plant response-like protein \\
\hline A0A0F9XMI8 & 54,00 & 2 & 1 & 1 & Não & 35711 & Glycosylhydrolase family $61-2$ \\
\hline A0A0F9X368 & 36,34 & 2 & 1 & 1 & Não & 50399 & $\begin{array}{l}\text { Uncharacterized protein (por BLAST: } \\
\text { Ribosomal protein YmL35 / T. reesei } \\
\text { com } 88,5 \% \text { de identidade) }\end{array}$ \\
\hline
\end{tabular}




\begin{tabular}{|c|c|c|c|c|c|c|c|}
\hline A0A0F9XL67 & 33,63 & 2 & 1 & 1 & Sim & 47504 & $\begin{array}{c}\text { Uncharacterized protein (por BLAST: } \\
\text { Aldose-1-epimerase / T. reesei com } \\
84,0 \% \text { de identidade) }\end{array}$ \\
\hline A0A0F9ZN40 & 32,73 & 2 & 1 & 1 & Não & 40688 & Feruloyl esterase B \\
\hline A0A0F9ZVH5 & 28,68 & 3 & 1 & 1 & Não & 18513 & $\begin{array}{c}\text { Uncharacterized protein (por BLAST: } \\
\text { Putative mitotic spindle biogenesis } \\
\text { protein Spc19/T. reesei com 85,5\% de } \\
\text { identidade e Mitotic spindle biogenesis } \\
\text { protein Spc19/ Purpureocillium } \\
\text { lilacinum com 73,3\% de identidade) }\end{array}$ \\
\hline A0A0F9ZB13 & 28,68 & 1 & 1 & 1 & Não & 47161 & $\begin{array}{c}\text { Uncharacterized protein (por BLAST: } \\
\text { RNA polymerase II mediator complex } \\
\text { componente / Colletotrichum } \\
\text { gloeosporioides com 35,1\% de } \\
\text { identidade) }\end{array}$ \\
\hline A0A0F9XSG0 & 28,68 & 0 & 1 & 1 & Não & 138262 & Enterobactin synthetase component F \\
\hline
\end{tabular}

Tabela 11. Resultado das identificações das proteínas da banda B6 do BN-PAGE.

\begin{tabular}{|c|c|c|c|c|c|c|c|}
\hline Número de Acesso & Score & $\begin{array}{c}\text { Cobertura } \\
(\%)\end{array}$ & \# Peptídeos & $\begin{array}{c}\text { \# Peptídeos } \\
\text { Únicos }\end{array}$ & PTMs & $\begin{array}{c}\text { Massa } \\
\text { Média (Da) }\end{array}$ & Descrição (em inglês) \\
\hline A0A0F9ZN40 & 159,54 & 11 & 11 & 11 & Sim & 40688 & Feruloyl esterase B \\
\hline A0A0F9WYH5 & 154,42 & 10 & 6 & 6 & Sim & 45007 & Cellulase \\
\hline A0A0F9XHQ5 & 135,86 & 8 & 4 & 4 & Sim & 48969 & Glucanase \\
\hline A0A0F9XMI8 & 117,77 & 6 & 3 & 3 & Não & 35711 & Glycosylhydrolase family 61-2 \\
\hline A0A0F9X224 & 117,35 & 6 & 3 & 3 & Sim & 62637 & $\begin{array}{c}\text { Uncharacterized protein (por BLAST: } \\
\text { Amidase / T. reesei com 93,1\% de } \\
\text { identidade) }\end{array}$ \\
\hline A0A0G0AN43 & 117,30 & 7 & 3 & 3 & Sim & 51955 & Murein transglycosylase \\
\hline A0A0F9ZH76 & 100,86 & 5 & 4 & 4 & Sim & 79362 & Purple acid phosphatase \\
\hline
\end{tabular}




\begin{tabular}{|c|c|c|c|c|c|c|c|}
\hline A0A0F9XFJ7 & 95,45 & 3 & 2 & 2 & Sim & 63621 & $\begin{array}{l}\text { Uncharacterized protein (por BLAST: } \\
\text { Glycoside hydrolase family } 71 \text { protein / } \\
\text { T. virens com } 89,9 \% \text { de identidade) }\end{array}$ \\
\hline $\mathrm{O} 14402$ & 94,20 & 3 & 2 & 2 & Sim & 107912 & Beta-1,3 exoglucanase \\
\hline A0A0F9Y3W7 & 82,76 & 4 & 2 & 2 & Sim & 41830 & $\begin{array}{l}\text { Uncharacterized protein (por BLAST: } \\
\text { ECM33-like protein / T. reesei com } \\
\text { 86,4\% de identidade e Cell wall protein } \\
\text { / T. reesei com } 85,2 \% \text { de identidade) }\end{array}$ \\
\hline Q599K8 & 77,80 & 3 & 2 & 2 & Não & 66255 & Glucoamylase \\
\hline A0A0G0A7Y5 & 77,80 & 2 & 2 & 2 & Não & 69967 & Glucoamylase \\
\hline M4T2Q5 & 75,25 & 2 & 2 & 2 & Sim & 47164 & Man5A \\
\hline A0A0G0AGG8 & 75,25 & 2 & 2 & 2 & Sim & 46231 & Mannanase \\
\hline G8FPZ8 & 73,13 & 10 & 1 & 1 & Não & 14389 & Eliciting plant response-like protein \\
\hline A0A0F9ZG17 & 54,28 & 5 & 1 & 1 & Sim & 37881 & Polygalacturonase \\
\hline B7ZEN3 & 54,28 & 4 & 1 & 1 & Sim & 38296 & Endopolygalacturonase \\
\hline A0A0G0A3D5 & 42,47 & 8 & 1 & 1 & Não & 17578 & Ubiquitin-40S ribosomal protein $\mathrm{S} 27 \mathrm{a}$ \\
\hline H9BVC3 & 42,47 & 5 & 1 & 1 & Não & 29611 & Ubiquitin (Fragment) \\
\hline A0A0F9XL67 & 40,00 & 2 & 1 & 1 & Sim & 47504 & $\begin{array}{c}\text { Uncharacterized protein (por BLAST: } \\
\text { Aldose-1-epimerase / T. reesei com } \\
84,0 \% \text { de identidade) }\end{array}$ \\
\hline A0A0F9XNN2 & 34,96 & 1 & 1 & 1 & Não & 72805 & Phosphoinositide phospholipase C \\
\hline
\end{tabular}

Tabela 12. Resultado das identificações das proteínas da banda B7 do BN-PAGE.

\begin{tabular}{|c|c|c|c|c|c|c|c|}
\hline Número de Acesso & Score & $\begin{array}{c}\text { Cobertura } \\
(\boldsymbol{\%})\end{array}$ & \# Peptídeos & $\begin{array}{c}\text { \# Peptídeos } \\
\text { Únicos }\end{array}$ & PTMs & $\begin{array}{c}\text { Massa } \\
\text { Média (Da) }\end{array}$ & Descrição (em inglês) \\
\hline A0A0F9ZG17 & 222,18 & 18 & 16 & 16 & Sim & 37881 & Polygalacturonase \\
\hline A0A0G0AGG8 & 149,94 & 6 & 6 & 6 & Sim & 46231 & Mannanase \\
\hline A0A0F9XHQ5 & 139,80 & 5 & 4 & 4 & Sim & 48969 & Glucanase \\
\hline
\end{tabular}




\begin{tabular}{|c|c|c|c|c|c|c|c|}
\hline A0A0G0AN43 & 136,83 & 7 & 3 & 3 & Sim & 51955 & Murein transglycosylase \\
\hline A0A0F9WYH5 & 122,87 & 5 & 2 & 2 & Sim & 45007 & Cellulase \\
\hline A0A0F9ZN40 & 119,54 & 9 & 4 & 3 & Sim & 40688 & Feruloyl esterase B \\
\hline A0A0F9XMI8 & 114,90 & 6 & 3 & 3 & Não & 35711 & Glycosylhydrolase family 61-2 \\
\hline A0A0F9Y3W7 & 96,37 & 4 & 2 & 2 & Sim & 41830 & $\begin{array}{c}\text { Uncharacterized protein (por BLAST: } \\
\text { ECM33-like protein / T. reesei com } \\
86,4 \% \text { de identidade e Cell wall protein } \\
\text { / T. reesei com 85,2\% de identidade) }\end{array}$ \\
\hline A0A0F9ZH76 & 89,81 & 2 & 1 & 1 & Não & 79362 & Purple acid phosphatase \\
\hline H9BBE8 & 80,65 & 2 & 1 & 1 & Sim & 51326 & Glucanase \\
\hline A0A0F9X2V9 & 80,65 & 2 & 1 & 1 & Sim & 53003 & Glucanase \\
\hline Q599K8 & 72,75 & 1 & 1 & 1 & Não & 66255 & Glucoamylase \\
\hline A0A0G0A7Y5 & 72,75 & 1 & 1 & 1 & Não & 69967 & Glucoamylase \\
\hline A0A0G0ARJ7 & 72,64 & 4 & 1 & 1 & Não & 40277 & $\begin{array}{c}\text { Uncharacterized protein (por BLAST: } \\
\text { Glycoside hydrolase family 16 protein / } \\
\text { virens com 91,5\% de identidade) }\end{array}$ \\
\hline A0A0F9ZXC9 & 67,01 & 1 & 1 & 1 & Sim & 117541 & WSC domain-containing protein \\
\hline A0A0F9XL67 & 63,24 & 2 & 1 & 1 & Sim & 47504 & $\begin{array}{c}\text { Uncharacterized protein (por BLAST: } \\
\text { Aldose-1-epimerase / } T \text {. reesei com } \\
84,0 \% \text { de identidade) }\end{array}$ \\
\hline A0A0F9ZY32 & 62,73 & 2 & 1 & 1 & Sim & 107210 & Glucan 1,3-beta-glucosidase \\
\hline O14402 & 62,73 & 2 & 1 & 1 & Sim & 107912 & Beta-1,3 exoglucanase \\
\hline A0A0F9XFJ7 & 39,58 & 1 & 1 & 1 & Sim & 63621 & $\begin{array}{c}\text { Uncharacterized protein (por BLAST: } \\
\text { Glycoside hydrolase family 71 protein / } \\
\text { T. virens com 89,9\% de identidade) }\end{array}$ \\
\hline
\end{tabular}


Tabela 13. Resultado das identificações das proteínas da banda B8 do BN-PAGE.

\begin{tabular}{|c|c|c|c|c|c|c|c|}
\hline Número de Acesso & Score & $\begin{array}{c}\text { Cobertura } \\
(\%)\end{array}$ & \# Peptídeos & $\begin{array}{c}\text { \# Peptídeos } \\
\text { Únicos }\end{array}$ & PTMs & $\begin{array}{c}\text { Massa } \\
\text { Média (Da) }\end{array}$ & Descrição (em inglês) \\
\hline- & - & - & - & - & - & - & - \\
\hline
\end{tabular}

Tabela 14. Resultado das identificações das proteínas da banda B9 do BN-PAGE.

\begin{tabular}{|c|c|c|c|c|c|c|c|}
\hline Número de Acesso & Score & $\begin{array}{c}\text { Cobertura } \\
(\%)\end{array}$ & \# Peptídeos & $\begin{array}{l}\text { \# Peptídeos } \\
\text { Únicos }\end{array}$ & PTMs & $\begin{array}{c}\text { Massa } \\
\text { Média (Da) }\end{array}$ & Descrição (em inglês) \\
\hline A0A0F9X2V9 & 187,88 & 15 & 10 & 2 & Sim & 53003 & Glucanase \\
\hline Q9P8P3 & 180,31 & 20 & 9 & 1 & Sim & 53216 & Exoglucanase 1 \\
\hline A0A0F9WYH5 & 121,23 & 5 & 2 & 2 & Sim & 45007 & Cellulase \\
\hline A0A0F9ZN40 & 113,06 & 8 & 4 & 4 & Sim & 40688 & Feruloyl esterase B \\
\hline A0A0F9ZH76 & 93,29 & 3 & 2 & 2 & Sim & 79362 & Purple acid phosphatase \\
\hline A0A0G0AGG8 & 90,67 & 6 & 3 & 3 & Sim & 46231 & Mannanase \\
\hline B8XUV8 & 87,10 & 16 & 2 & 2 & Não & 23768 & Actin (Fragment) \\
\hline A0A0G0A4Q2 & 86,19 & 4 & 1 & 1 & Sim & 52710 & Alpha-L-arabinofuranosidase B \\
\hline G8FPZ8 & 78,82 & 10 & 1 & 1 & Não & 14389 & Eliciting plant response-like protein \\
\hline A0A0F9X463 & 77,82 & 3 & 2 & 2 & Sim & 52095 & $\begin{array}{c}\text { Uncharacterized protein (por BLAST: } \\
\text { Expansin-like protein/ T. virens com } \\
91,6 \% \text { de identidade e Swollenin / T. } \\
\text { pseudokoningii com } 88,8 \% \text { de } \\
\text { identidade) }\end{array}$ \\
\hline A0A0F9XMI8 & 77,15 & 4 & 2 & 2 & Não & 35711 & Glycosylhydrolase family $61-2$ \\
\hline A0A0F9Y0Z9 & 75,97 & 6 & 2 & 2 & Sim & 51420 & Alpha-L-arabinofuranosidase B \\
\hline A0A0F9XL67 & 67,48 & 3 & 1 & 1 & Sim & 47504 & $\begin{array}{c}\text { Uncharacterized protein (por BLAST: } \\
\text { Aldose-1-epimerase / T. reesei com } \\
84,0 \% \text { de identidade) }\end{array}$ \\
\hline
\end{tabular}




\begin{tabular}{|c|c|c|c|c|c|c|c|}
\hline A0A0F9ZG17 & 60,51 & 5 & 1 & 1 & Sim & 37881 & Polygalacturonase \\
\hline B7ZEN3 & 60,51 & 4 & 1 & 1 & Sim & 38296 & Endopolygalacturonase \\
\hline A0A0F9Y3W7 & 53,50 & 2 & 1 & 1 & Não & 41830 & $\begin{array}{c}\text { Uncharacterized protein (por BLAST: } \\
\text { ECM33-like protein / T. reesei com } \\
86,4 \% \text { de identidade e Cell wall protein } \\
/ T \text { reesei com 85,2\% de identidade) }\end{array}$ \\
\hline A0A0F9XBN1 & 48,25 & 4 & 1 & 1 & Não & 38579 & $\begin{array}{c}\text { Uncharacterized protein (por BLAST: } \\
\text { Glycoside hydrolase family 93 protein / } \\
T \text {. virens com 87,9\% de identidade) }\end{array}$ \\
\hline A0A0G0A171 & 47,53 & 8 & 1 & 1 & Não & 24024 & Endo-1,4-beta-xylanase \\
\hline
\end{tabular}

Tabela 15. Resultado das identificações das proteínas da banda B10 do BN-PAGE.

\begin{tabular}{|c|c|c|c|c|c|c|c|}
\hline Número de Acesso & Score & $\begin{array}{c}\text { Cobertura } \\
(\%)\end{array}$ & \# Peptídeos & $\begin{array}{c}\text { \# Péptídeos } \\
\text { Unicos }\end{array}$ & PTMs & $\begin{array}{c}\text { Massa } \\
\text { Média (Da) }\end{array}$ & Descrição (em inglês) \\
\hline- & - & - & - & - & - & - & - \\
\hline
\end{tabular}

Tabela 16. Resultado das identificações das proteínas da banda B11 do BN-PAGE.

\begin{tabular}{|c|c|c|c|c|c|c|c|}
\hline Número de Acesso & Score & $\begin{array}{c}\text { Cobertura } \\
(\boldsymbol{\%})\end{array}$ & \# Peptídeos & $\begin{array}{c}\text { \# Peptídeos } \\
\text { Únicos }\end{array}$ & PTMs & $\begin{array}{c}\text { Massa } \\
\text { Média (Da) }\end{array}$ & Descrição (em inglês) \\
\hline A0A0F9X2V9 & 203,28 & 14 & 11 & 11 & Sim & 53003 & Glucanase \\
\hline A0A0F9XP88 & 153,06 & 10 & 8 & 8 & Sim & 30201 & Acetylxylan esterase \\
\hline A0A0F9Y245 & 139,36 & 9 & 3 & 3 & Sim & 37299 & Alpha/beta hydrolase \\
\hline A0A0F9ZN40 & 133,39 & 10 & 6 & 6 & Sim & 40688 & Feruloyl esterase B \\
\hline A0A0G0A4Q2 & 125,97 & 8 & 3 & 2 & Sim & 52710 & Alpha-L-arabinofuranosidase B \\
\hline A0A0F9Y0Z9 & 123,43 & 4 & 5 & 4 & Sim & 51420 & Alpha-L-arabinofuranosidase B \\
\hline A0A0G0AME2 & 108,62 & 7 & 2 & 2 & Sim & 33450 & $\begin{array}{c}\text { Uncharacterized protein (por BLAST: } \\
\text { Carbohydrate-binding module family 1 }\end{array}$ \\
\hline
\end{tabular}




\begin{tabular}{|c|c|c|c|c|c|c|c|}
\hline & & & & & & & $\begin{array}{c}\text { protein / T. atroviride com } 82,4 \% \text { de } \\
\text { identidade) }\end{array}$ \\
\hline A0A0F9Y3W7 & 91,27 & 4 & 2 & 2 & Sim & 41830 & $\begin{array}{l}\text { Uncharacterized protein (por BLAST: } \\
\text { ECM33-like protein / T. reesei com } \\
\text { 86,4\% de identidade e Cell wall protein } \\
\text { / T. reesei com } 85,2 \% \text { de identidade) }\end{array}$ \\
\hline A0A0F9X463 & 87,18 & 5 & 3 & 3 & Sim & 52095 & $\begin{array}{c}\text { Uncharacterized protein (por BLAST: } \\
\text { Expansin-like protein/ T. virens com } \\
\text { 91,6\% de identidade e Swollenin / T. } \\
\text { pseudokoningii com } 88,8 \% \text { de } \\
\text { identidade) }\end{array}$ \\
\hline A0A0G0A171 & 74,62 & 8 & 2 & 2 & Sim & 24024 & Endo-1,4-beta-xylanase \\
\hline A0A0F9ZZN6 & 72,98 & 5 & 3 & 3 & Sim & 57215 & 1,3-beta-glucanosyltransferase \\
\hline G8FPZ8 & 64,48 & 10 & 1 & 1 & Não & 14389 & Eliciting plant response-like protein \\
\hline A0A0F9XKY7 & 57,05 & 3 & 1 & 1 & Sim & 30568 & $\begin{array}{l}\text { Uncharacterized protein (por BLAST: } \\
\text { Carbohydrate esterase family } 5 \text { protein / } \\
\text { T. reesei com } 91,7 \% \text { de identidade) }\end{array}$ \\
\hline A0A0F9X878 & 56,57 & 1 & 1 & 1 & Não & 166523 & WSC domain-containing protein \\
\hline A0A0F9XMI8 & 52,05 & 2 & 1 & 1 & Não & 35711 & Glycosylhydrolase family $61-2$ \\
\hline A0A0F9XL67 & 38,66 & 2 & 1 & 1 & Sim & 47504 & $\begin{array}{c}\text { Uncharacterized protein (por BLAST: } \\
\text { Aldose-1-epimerase / T. reesei com } \\
84,0 \% \text { de identidade) } \\
\end{array}$ \\
\hline
\end{tabular}

Tabela 17. Resultado das identificações das proteínas da banda B12 do BN-PAGE.

\begin{tabular}{|c|c|c|c|c|c|c|c|}
\hline Número de Acesso & Score & $\begin{array}{c}\text { Cobertura } \\
(\%)\end{array}$ & \# Peptídeos & $\begin{array}{c}\text { \# Peptídeos } \\
\text { Únicos }\end{array}$ & PTMs & $\begin{array}{c}\text { Massa } \\
\text { Média (Da) }\end{array}$ & Descrição (em inglês) \\
\hline- & - & - & - & - & - & - & - \\
\hline
\end{tabular}


Tabela 18. Resultado das identificações das proteínas da banda B13 do BN-PAGE.

\begin{tabular}{|c|c|c|c|c|c|c|c|}
\hline Número de Acesso & Score & $\begin{array}{c}\text { Cobertura } \\
(\%)\end{array}$ & \# Peptídeos & $\begin{array}{c}\text { \# Peptídeos } \\
\text { Únicos }\end{array}$ & PTMs & $\begin{array}{c}\text { Massa } \\
\text { Média (Da) }\end{array}$ & Descrição (em inglês) \\
\hline A0A0G0A171 & 209,95 & 14 & 13 & 13 & Sim & 24024 & Endo-1,4-beta-xylanase \\
\hline A0A0F9X2V9 & 198,13 & 12 & 10 & 10 & Sim & 53003 & Glucanase \\
\hline A0A0F9Y0Z9 & 155,92 & 5 & 8 & 6 & Sim & 51420 & Alpha-L-arabinofuranosidase B \\
\hline A0A0G0A4Q2 & 152,18 & 11 & 5 & 3 & Sim & 52710 & Alpha-L-arabinofuranosidase $\mathrm{B}$ \\
\hline A0A0F9Y0Y9 & 140,08 & 4 & 6 & 6 & Sim & 30409 & Endo-1,4-beta-xylanase \\
\hline A0A0G0AME2 & 122,42 & 4 & 3 & 3 & Sim & 33450 & $\begin{array}{c}\text { Uncharacterized protein (por BLAST: } \\
\text { Carbohydrate-binding module family } 1 \\
\text { protein / T. atroviride com } 82,4 \% \text { de } \\
\text { identidade) }\end{array}$ \\
\hline A0A0F9Y245 & 113,86 & 11 & 3 & 3 & Sim & 37299 & Alpha/beta hydrolase \\
\hline A0A0F9ZN40 & 109,68 & 8 & 4 & 4 & Sim & 40688 & Feruloyl esterase B \\
\hline A0A0F9XP88 & 87,88 & 6 & 2 & 2 & Sim & 30201 & Acetylxylan esterase \\
\hline A0A0F9Y3W7 & 86,75 & 4 & 2 & 2 & Sim & 41830 & $\begin{array}{l}\text { Uncharacterized protein (por BLAST: } \\
\text { ECM33-like protein / T. reesei com } \\
\text { 86,4\% de identidade e Cell wall protein } \\
\text { / T. reesei com } 85,2 \% \text { de identidade) }\end{array}$ \\
\hline A9XE70 & 81,80 & 7 & 2 & 2 & Sim & 25238 & Endochitinase 42 (Fragment) \\
\hline A0A024HW94 & 81,80 & 7 & 2 & 2 & Sim & 27697 & Chitinase $18-5$ \\
\hline Q4KUQ9 & 81,80 & 5 & 2 & 2 & Sim & 34431 & Bacterial-type endochitinase \\
\hline A6N6J0 & 81,80 & 4 & 2 & 2 & Sim & 46380 & Endochitinase 46 \\
\hline Q9C1T7 & 81,80 & 4 & 2 & 2 & Sim & 46410 & Endochitinase 42 \\
\hline A0A0F9ZWP3 & 81,69 & 2 & 2 & 2 & Sim & 96970 & $\begin{array}{c}\text { Uncharacterized protein (por BLAST: } \\
\text { Carboxy terminal WSC domain- } \\
\text { containing protein / T. reesei com } \\
85,1 \% \text { de identidade) }\end{array}$ \\
\hline G8FPZ8 & 71,00 & 10 & 1 & 1 & Não & 14389 & Eliciting plant response-like protein \\
\hline
\end{tabular}




\begin{tabular}{|c|c|c|c|c|c|c|c|}
\hline A0A0F9ZKA8 & 66,62 & 4 & 2 & 2 & Sim & 56280 & 1,3-beta-glucanosyltransferase \\
\hline A0A0F9ZG17 & 57,50 & 5 & 1 & 1 & Não & 37881 & Polygalacturonase \\
\hline B7ZEN3 & 57,50 & 4 & 1 & 1 & Não & 38296 & Endopolygalacturonase \\
\hline A0A0F9XMI8 & 52,53 & 2 & 1 & 1 & Não & 35711 & Glycosylhydrolase family 61-2 \\
\hline A0A0F9XR78 & 44,00 & 2 & 1 & 1 & Não & 49246 & Eukaryotic aspartyl protease \\
\hline A0A0F9ZWI7 & 37,51 & 1 & 1 & 1 & Sim & 70421 & $\begin{array}{c}\text { Uncharacterized protein (por BLAST: } \\
\text { Duf1680 domain containing protein / } \\
\text { Ophiocordyceps sinensis com 67,6\% de } \\
\text { identidade) }\end{array}$ \\
\hline A0A0F9XN15 & 35,66 & 2 & 1 & 1 & Sim & 48188 & Alpha-galactosidase \\
\hline A0A0F9X878 & 34,42 & 1 & 1 & 1 & Não & 166523 & WSC domain-containing protein \\
\hline A0A0F9XW90 & 30,77 & 2 & 1 & 1 & Sim & 47440 & CoA-transferase family III \\
\hline
\end{tabular}

Tabela 19. Resultado das identificações das proteínas da banda C1 do BN-PAGE.

\begin{tabular}{|c|c|c|c|c|c|c|c|}
\hline Número de Acesso & Score & $\begin{array}{c}\text { Cobertura } \\
(\mathbf{\%})\end{array}$ & \# Peptídeos & $\begin{array}{c}\text { \# Peptídeos } \\
\text { Únicos }\end{array}$ & PTMs & $\begin{array}{c}\text { Massa } \\
\text { Média (Da) }\end{array}$ & Descrição (em inglês) \\
\hline A0A0G0A408 & 226,43 & 16 & 14 & 14 & Sim & 86623 & $\begin{array}{c}\text { Glycosyl hydrolase family } 3 \text { N terminal } \\
\text { domain-containing protein }\end{array}$ \\
\hline G8FPZ8 & 135,58 & 18 & 3 & 3 & Sim & 14389 & Eliciting plant response-like protein \\
\hline A0A0F9XCM6 & 113,59 & 4 & 3 & 3 & Sim & 106,898 & $\begin{array}{c}\text { Uncharacterized protein (por BLAST: } \\
\text { Pentatricopeptide repeat-containing } \\
\text { protein / T. reesei com } 85,9 \% \text { de } \\
\text { identidade) }\end{array}$ \\
\hline A0A0F9Y5T3 & 82,60 & 7 & 2 & 2 & Sim & 36156 & $\begin{array}{c}\text { Glyceraldehyde-3-phosphate } \\
\text { dehydrogenase }\end{array}$ \\
\hline A0A0F9Y245 & 62,43 & 4 & 1 & 1 & Não & 37299 & Alpha/beta hydrolase \\
\hline A0A0G0AEM7 & 59,71 & 4 & 1 & 1 & Não & 49388 & Glucanase \\
\hline
\end{tabular}




\begin{tabular}{|c|c|c|c|c|c|c|c|}
\hline A0A0F9Z7Y6 & 47,65 & 5 & 1 & 1 & Sim & 23425 & $\begin{array}{c}\text { Uncharacterized protein (por BLAST: } \\
\text { Str. FM013 / Penicillium camemberti } \\
\text { com 33,0\% de identidade) }\end{array}$ \\
\hline A0A0F9XRV0 & 38,89 & 1 & 1 & 1 & Não & 78113 & Chaperonin GroL \\
\hline
\end{tabular}

Tabela 20. Resultado das identificações das proteínas da banda C2 do BN-PAGE.

\begin{tabular}{|c|c|c|c|c|c|c|c|}
\hline Número de Acesso & Score & $\begin{array}{c}\text { Cobertura } \\
(\%)\end{array}$ & \# Peptídeos & $\begin{array}{l}\text { \# Peptídeos } \\
\text { Únicos }\end{array}$ & PTMs & $\begin{array}{c}\text { Massa } \\
\text { Média }(\text { Da) }\end{array}$ & Descrição (em inglês) \\
\hline A0A0G0A408 & 232,30 & 17 & 23 & 23 & Sim & 86623 & $\begin{array}{l}\text { Glycosyl hydrolase family } 3 \mathrm{~N} \text { terminal } \\
\text { domain-containing protein }\end{array}$ \\
\hline G8FPZ8 & 90,58 & 18 & 2 & 2 & Sim & 14389 & Eliciting plant response-like protein \\
\hline A0A0F9Y245 & 85,59 & 6 & 2 & 2 & Sim & 37299 & Alpha/beta hydrolase \\
\hline A0A0F9XP97 & 82,54 & 10 & 3 & 3 & Não & 41622 & Actin \\
\hline A0A0F9WYH5 & 73,98 & 4 & 1 & 1 & Sim & 45007 & Cellulase \\
\hline A0A0F9Y5T3 & 58,40 & 4 & 1 & 1 & Sim & 36156 & $\begin{array}{l}\text { Glyceraldehyde-3-phosphate } \\
\text { dehydrogenase }\end{array}$ \\
\hline A0A0F9X224 & 57,97 & 3 & 2 & 2 & Sim & 62637 & $\begin{array}{c}\text { Uncharacterized protein (por BLAST: } \\
\text { Amidase / T. reesei com 93,1\% de } \\
\text { identidade) }\end{array}$ \\
\hline A0A0F9Z7Y6 & 55,90 & 5 & 1 & 1 & Sim & 23425 & $\begin{array}{l}\text { Uncharacterized protein (por BLAST: } \\
\text { Str. FM013 / Penicillium camemberti } \\
\text { com 33,0\% de identidade) }\end{array}$ \\
\hline A0A0F9Y3W7 & 50,23 & 2 & 1 & 1 & Não & 41830 & $\begin{array}{l}\text { Uncharacterized protein (por BLAST: } \\
\text { ECM33-like protein / T. reesei com } \\
\text { 86,4\% de identidade e Cell wall protein } \\
\text { / T. reesei com } 85,2 \% \text { de identidade) }\end{array}$ \\
\hline A0A0F9ZVD3 & 42,39 & 3 & 1 & 1 & Não & 84387 & Beta-glucosidase \\
\hline A0A0G0AGG8 & 42,12 & 2 & 1 & 1 & Sim & 46231 & Mannanase \\
\hline M4T2Q5 & 42,12 & 2 & 1 & 1 & Sim & 47164 & Man5A \\
\hline
\end{tabular}




\begin{tabular}{|c|c|c|c|c|c|c|c|}
\hline A0A0G0ARJ7 & 39,35 & 4 & 1 & 1 & Não & 40277 & $\begin{array}{c}\text { Uncharacterized protein (por BLAST: } \\
\text { Glycoside hydrolase family 16 protein / } \\
\text { T. virens com 91,5\% de identidade) }\end{array}$ \\
\hline A0A0G0AN43 & 36,42 & 2 & 1 & 1 & Sim & 51955 & Murein transglycosylase \\
\hline A0A0F9XCM6 & 30,55 & 2 & 1 & 1 & Sim & 106898 & $\begin{array}{c}\text { Uncharacterized protein (por BLAST: } \\
\text { Pentatricopeptide repeat-containing } \\
\text { protein / T. reesei com 85,9\% de } \\
\text { identidade) }\end{array}$ \\
\hline
\end{tabular}

Tabela 21. Resultado das identificações das proteínas da banda C3 do BN-PAGE.

\begin{tabular}{|c|c|c|c|c|c|c|c|}
\hline Número de Acesso & Score & $\begin{array}{c}\text { Cobertura } \\
(\%)\end{array}$ & \# Peptídeos & $\begin{array}{c}\text { \# Peptídeos } \\
\text { Únicos }\end{array}$ & PTMs & $\begin{array}{c}\text { Massa } \\
\text { Média (Da) }\end{array}$ & Descrição (em inglês) \\
\hline A0A0G0A408 & 246,97 & 19 & 29 & 29 & Sim & 86623 & $\begin{array}{c}\text { Glycosyl hydrolase family } 3 \text { N terminal } \\
\text { domain-containing protein }\end{array}$ \\
\hline P87258 & 237,42 & 35 & 31 & 9 & Sim & 64534 & Beta-hexosaminidase \\
\hline Q8NIN7 & 206,70 & 26 & 23 & 2 & Sim & 64537 & Beta-hexosaminidase \\
\hline A0A0F9Y0X0 & 166,67 & 10 & 8 & 8 & Sim & 92791 & Beta-glucosidase \\
\hline P78738 & 158,50 & 15 & 10 & 1 & Sim & 64234 & Beta-hexosaminidase \\
\hline A0A0F9X224 & 153,22 & 17 & 8 & 8 & Sim & 62637 & $\begin{array}{c}\text { Uncharacterized protein (por BLAST: } \\
\text { Amidase / T. reesei com 93,1\% de } \\
\text { identidade) }\end{array}$ \\
\hline A0A0G0ARJ7 & 112,95 & 6 & 2 & 2 & Não & 40277 & $\begin{array}{c}\text { Uncharacterized protein (por BLAST: } \\
\text { Glycoside hydrolase family 16 protein / } \\
\text { T. virens com 91,5\% de identidade) }\end{array}$ \\
\hline A0A0F9Y245 & 107,02 & 11 & 3 & 3 & Sim & 37299 & Alpha/beta hydrolase \\
\hline A0A0G0AN43 & 96,30 & 5 & 2 & 2 & Sim & 51955 & Murein transglycosylase \\
\hline A0A0F9Y3W7 & 68,23 & 4 & 2 & 2 & Sim & 41830 & $\begin{array}{c}\text { Uncharacterized protein (por BLAST: } \\
\text { ECM33-like protein / T. reesei com }\end{array}$ \\
\hline
\end{tabular}




\begin{tabular}{|c|c|c|c|c|c|c|c|}
\hline & & & & & & & $\begin{array}{l}86,4 \% \text { de identidade e Cell wall protein } \\
\text { / T. reesei com } 85,2 \% \text { de identidade) }\end{array}$ \\
\hline Q599K8 & 67,73 & 3 & 2 & 2 & Não & 66255 & Glucoamylase \\
\hline A0A0G0A7Y5 & 67,73 & 2 & 2 & 2 & Não & 69967 & Glucoamylase \\
\hline A0A0F9ZVD3 & 57,05 & 3 & 1 & 1 & Sim & 84387 & Beta-glucosidase \\
\hline A0A0G0AGG8 & 55,02 & 2 & 1 & 1 & Sim & 46231 & Mannanase \\
\hline M4T2Q5 & 55,02 & 2 & 1 & 1 & Sim & 47164 & Man5A \\
\hline A0A0F9XX62 & 54,72 & 2 & 1 & 1 & Não & 59632 & 3-phytase A \\
\hline A0A0F9WYH5 & 53,39 & 4 & 1 & 1 & Não & 45007 & Cellulase \\
\hline A0A0G0AEM7 & 52,39 & 4 & 1 & 1 & Não & 49388 & Glucanase \\
\hline G8FPZ8 & 52,08 & 10 & 1 & 1 & Não & 14389 & Eliciting plant response-like protein \\
\hline B8XUP5 & 49,61 & 8 & 1 & 1 & Não & 22887 & Actin (Fragment) \\
\hline A0A0F9XQN9 & 37,20 & 2 & 1 & 1 & Não & 25494 & $\begin{array}{c}\text { Uncharacterized protein (por BLAST: } \\
\text { Carbohydrate-binding domain, family } \\
\text { 9-like, subgroup / Pochonia } \\
\text { chlamydosporia com } 69,7 \% \text { de } \\
\text { identidade) }\end{array}$ \\
\hline A0A0G0ABT8 & 30,93 & 3 & 1 & 1 & Não & 36593 & $\begin{array}{c}\text { Uncharacterized protein (por BLAST: } \\
\text { NAD(P)-binding protein / T. reesei com } \\
78,2 \% \text { de identidade) } \\
\end{array}$ \\
\hline A0A0F9XGR6 & 29,69 & 0 & 1 & 1 & Sim & 186269 & $\begin{array}{l}\text { Uncharacterized protein (por BLAST: } \\
\text { Rho guanyl nucleotide exchange factor / } \\
\text { T. reesei com } 86,2 \% \text { de identidade) }\end{array}$ \\
\hline A0A0F9XG59 & 29,66 & 1 & 1 & 1 & Não & 99345 & Glutamyl aminopeptidase \\
\hline A0A0F9XW90 & 28,95 & 2 & 1 & 1 & Sim & 47440 & CoA-transferase family III \\
\hline
\end{tabular}


Tabela 22. Resultado das identificações das proteínas da banda C4 do BN-PAGE.

\begin{tabular}{|c|c|c|c|c|c|c|c|}
\hline Número de Acesso & Score & $\begin{array}{c}\text { Cobertura } \\
(\%)\end{array}$ & \# Peptídeos & $\begin{array}{l}\text { \# Peptídeos } \\
\text { Únicos }\end{array}$ & PTMs & $\begin{array}{c}\text { Massa } \\
\text { Média (Da) } \\
\end{array}$ & Descrição (em inglês) \\
\hline A0A0G0A408 & 229,80 & 15 & 16 & 16 & Sim & 86623 & $\begin{array}{c}\text { Glycosyl hydrolase family } 3 \mathrm{~N} \text { terminal } \\
\text { domain-containing protein }\end{array}$ \\
\hline P87258 & 229,37 & 29 & 21 & 4 & Sim & 64534 & Beta-hexosaminidase \\
\hline Q8NIN7 & 221,52 & 23 & 19 & 2 & Sim & 64537 & Beta-hexosaminidase \\
\hline A0A0F9X224 & 192,28 & 16 & 8 & 8 & Sim & 62637 & $\begin{array}{c}\text { Uncharacterized protein (por BLAST: } \\
\text { Amidase / T. reesei com } 93,1 \% \text { de } \\
\text { identidade) }\end{array}$ \\
\hline A0A0F9WYH5 & 174,55 & 6 & 7 & 6 & Sim & 45007 & Cellulase \\
\hline A0A0F9Y0X0 & 145,55 & 6 & 5 & 5 & Sim & 92791 & Beta-glucosidase \\
\hline A0A0G0ARJ7 & 136,65 & 8 & 3 & 3 & Não & 40277 & $\begin{array}{l}\text { Uncharacterized protein (por BLAST: } \\
\text { Glycoside hydrolase family } 16 \text { protein / } \\
\text { T. virens com } 91,5 \% \text { de identidade) }\end{array}$ \\
\hline A0A0F9XHQ5 & 111,28 & 4 & 2 & 2 & Sim & 48969 & Glucanase \\
\hline A0A0F9XP97 & 103,09 & 12 & 3 & 3 & Não & 41622 & Actin \\
\hline A0A0F9ZXC9 & 94,65 & 2 & 2 & 2 & Sim & 117541 & WSC domain-containing protein \\
\hline A0A0G0AGG8 & 80,45 & 2 & 2 & 2 & Sim & 46231 & Mannanase \\
\hline A0A0F9Y3W7 & 78,70 & 4 & 2 & 2 & Sim & 41830 & $\begin{array}{l}\text { Uncharacterized protein (por BLAST: } \\
\text { ECM33-like protein / T. reesei com } \\
\text { 86,4\% de identidade e Cell wall protein } \\
\text { / T. reesei com } 85,2 \% \text { de identidade) }\end{array}$ \\
\hline A0A0G0AEM7 & 71,10 & 4 & 1 & 1 & Sim & 49388 & Glucanase \\
\hline G8FPZ8 & 61,31 & 10 & 1 & 1 & Não & 14389 & Eliciting plant response-like protein \\
\hline
\end{tabular}




\begin{tabular}{|c|c|c|c|c|c|c|c|}
\hline A0A0F9XL67 & 61,09 & 3 & 1 & 1 & Sim & 47504 & $\begin{array}{c}\text { Uncharacterized protein (por BLAST: } \\
\text { Aldose- } 1 \text {-epimerase / } T \text {. reesei com } \\
84,0 \% \text { de identidade) } \\
\end{array}$ \\
\hline A0A0F9Y245 & 55,36 & 3 & 1 & 1 & Sim & 37299 & Alpha/beta hydrolase \\
\hline Q599K8 & 49,92 & 1 & 1 & 1 & Não & 66255 & Glucoamylase \\
\hline A0A0G0A7Y5 & 49,92 & 1 & 1 & 1 & Não & 69967 & Glucoamylase \\
\hline A0A0F9ZS41 & 45,99 & 1 & 1 & 1 & Não & 116867 & Acid trehalase \\
\hline A0A0F9XE92 & 40,19 & 2 & 1 & 1 & Sim & 61400 & $\begin{array}{l}\text { Uncharacterized protein (por BLAST: } \\
\text { HBS1-like protein / Escovopsis weberi } \\
\text { com } 37,4 \% \text { de identidade) }\end{array}$ \\
\hline A0A0F9XQN9 & 38,26 & 2 & 1 & 1 & Não & 25494 & $\begin{array}{c}\text { Uncharacterized protein (por BLAST: } \\
\text { Carbohydrate-binding domain, family } \\
\text { 9-like, subgroup / Pochonia } \\
\text { chlamydosporia com } 69,7 \% \text { de } \\
\text { identidade) }\end{array}$ \\
\hline A0A0F9XMI8 & 37,04 & 2 & 1 & 1 & Não & 35711 & Glycosylhydrolase family $61-2$ \\
\hline A0A0F9X9K8 & 37,00 & 2 & 1 & 1 & Não & 48200 & $\begin{array}{l}\text { Uncharacterized protein (por BLAST: } \\
\text { Acid phosphatase-like protein / T. reesei } \\
\text { com } 84,5 \% \text { de identidade) } \\
\end{array}$ \\
\hline A0A0F9XW90 & 35,83 & 2 & 1 & 1 & Sim & 47440 & CoA-transferase family III \\
\hline A0A0G0ALL6 & 28,93 & 1 & 1 & 1 & Não & 103984 & $\begin{array}{c}\text { Uncharacterized protein (por BLAST: } \\
\text { PAB1 binding protein / Pochonia } \\
\text { chlamydosporia com } 67,6 \% \text { de } \\
\text { identidade) }\end{array}$ \\
\hline A0A0G0AED0 & 28,32 & 1 & 1 & 1 & Sim & 113509 & 5'-3' exoribonuclease 2 \\
\hline A0A0F9XPU8 & 28,24 & 1 & 1 & 1 & Não & 86287 & $\begin{array}{l}\text { Uncharacterized protein (por BLAST: } \\
\text { HET-domain-containing protein / } T \text {. } \\
\text { reesei com } 74,8 \% \text { de identidade) }\end{array}$ \\
\hline
\end{tabular}


Tabela 23. Resultado das identificações das proteínas da banda C5 do BN-PAGE.

\begin{tabular}{|c|c|c|c|c|c|c|c|}
\hline Número de Acesso & Score & $\begin{array}{c}\text { Cobertura } \\
(\%)\end{array}$ & \# Peptídeos & $\begin{array}{l}\text { \# Peptídeos } \\
\text { Únicos }\end{array}$ & PTMs & $\begin{array}{c}\text { Massa } \\
\text { Média (Da) }\end{array}$ & Descrição (em inglês) \\
\hline A0A0G0A408 & 197,93 & 12 & 12 & 12 & Sim & 86623 & $\begin{array}{c}\text { Glycosyl hydrolase family } 3 \mathrm{~N} \text { terminal } \\
\text { domain-containing protein }\end{array}$ \\
\hline A0A0F9X224 & 161,14 & 12 & 6 & 6 & Sim & 62637 & $\begin{array}{c}\text { Uncharacterized protein (por BLAST: } \\
\text { Amidase / T. reesei com } 93,1 \% \text { de } \\
\text { identidade) }\end{array}$ \\
\hline O14402 & 154,51 & 5 & 5 & 4 & Sim & 107912 & Beta-1,3 exoglucanase \\
\hline A0A0G0AGG8 & 145,86 & 12 & 10 & 10 & Sim & 46231 & Mannanase \\
\hline A0A0F9XHQ5 & 136,63 & 8 & 5 & 5 & Sim & 48969 & Glucanase \\
\hline P87258 & 122,29 & 6 & 3 & 3 & Não & 64534 & Beta-hexosaminidase \\
\hline A0A0F9XP97 & 122,11 & 12 & 3 & 3 & Não & 41622 & Actin \\
\hline A0A0F9Y0X0 & 115,23 & 4 & 3 & 3 & Sim & 92791 & Beta-glucosidase \\
\hline A0A0F9ZY32 & 109,04 & 4 & 3 & 2 & Sim & 107210 & Glucan 1,3-beta-glucosidase \\
\hline A0A0G0ARJ7 & 105,07 & 6 & 2 & 2 & Não & 40277 & $\begin{array}{l}\text { Uncharacterized protein (por BLAST: } \\
\text { Glycoside hydrolase family } 16 \text { protein / } \\
\text { T. virens com } 91,5 \% \text { de identidade) }\end{array}$ \\
\hline G8FPZ8 & 98,90 & 18 & 2 & 2 & Sim & 14389 & Eliciting plant response-like protein \\
\hline A0A0F9ZXC9 & 98,74 & 2 & 2 & 2 & Sim & 117541 & WSC domain-containing protein \\
\hline A0A0F9Y3W7 & 89,95 & 4 & 2 & 2 & Sim & 41830 & $\begin{array}{l}\text { Uncharacterized protein (por BLAST: } \\
\text { ECM33-like protein / T. reesei com } \\
\text { 86,4\% de identidade e Cell wall protein } \\
\text { / T. reesei com } 85,2 \% \text { de identidade) }\end{array}$ \\
\hline A0A0F9WYH5 & 88,33 & 4 & 1 & 1 & Sim & 45007 & Cellulase \\
\hline Q599K8 & 69,09 & 3 & 2 & 2 & Não & 66255 & Glucoamylase \\
\hline A0A0G0A7Y5 & 69,09 & 2 & 2 & 2 & Não & 69967 & Glucoamylase \\
\hline A0A0F9XM06 & 55,52 & 6 & 1 & 1 & Sim & 24314 & $\begin{array}{l}\text { Uncharacterized protein (por BLAST: } \\
\text { Putative GPI anchored protein / }\end{array}$ \\
\hline
\end{tabular}




\begin{tabular}{|c|c|c|c|c|c|c|c|}
\hline & & & & & & & $\begin{array}{l}\text { Ustilaginoidea virens com } 58,2 \% \text { de } \\
\text { identidade e Expression library } \\
\text { immunization antigen } 1 / \text { Metarhizium } \\
\text { robertsii com } 60,7 \% \text { de identidade) }\end{array}$ \\
\hline A0A0F9Y245 & 48,84 & 3 & 1 & 1 & Sim & 37299 & Alpha/beta hydrolase \\
\hline A0A0F9X2V9 & 43,29 & 2 & 1 & 1 & Sim & 53003 & Glucanase \\
\hline D7RF10 & 43,29 & 2 & 1 & 1 & Sim & 52991 & Glucanase \\
\hline A0A0F9XQN9 & 39,26 & 2 & 1 & 1 & Não & 25494 & $\begin{array}{l}\text { Uncharacterized protein (por BLAST: } \\
\text { Carbohydrate-binding domain, family } \\
\text { 9-like, subgroup / Pochonia } \\
\text { chlamydosporia com } 69,7 \% \text { de } \\
\text { identidade) }\end{array}$ \\
\hline A0A0G0AED0 & 29,98 & 1 & 1 & 1 & Sim & 113509 & 5'-3' exoribonuclease 2 \\
\hline A0A0F9XSQ1 & 29,02 & 1 & 1 & 1 & Sim & 85004 & $\begin{array}{c}\text { Uncharacterized protein (por BLAST: } \\
\text { WGS project CABT00000000 data / } \\
\text { Sordaria macrospora com } 37,7 \% \text { de } \\
\text { identidade) }\end{array}$ \\
\hline A0A0F9Z848 & 28,37 & 1 & 1 & 1 & Não & 97705 & Trehalose 6-phosphate synthase \\
\hline A0A0F9XXJ4 & 27,95 & 3 & 1 & 1 & Não & 18080 & $\begin{array}{l}\text { Uncharacterized protein (por BLAST: } \\
\text { GL14245 / Drosophila persimilis com } \\
34,0 \% \text { de identidade) }\end{array}$ \\
\hline A0A0F9Y4U4 & 27,95 & 1 & 1 & 1 & Não & 60218 & $\begin{array}{l}\text { Uncharacterized protein (por BLAST: } \\
\text { Ferredoxin reductase-like, C-terminal } \\
\text { NADP-linked / Glarea lozoyensis com } \\
\text { 51,9\% de identidade e Superoxide- } \\
\text { generating NADPH oxidase heavy } \\
\text { chain subunit A / Madurella } \\
\text { mycetomatis com 54,5\% de identidade) }\end{array}$ \\
\hline
\end{tabular}




\begin{tabular}{|c|c|c|c|c|c|c|c|}
\hline A0A0F9WUW5 & 27,95 & 1 & 1 & 1 & Não & 63421 & $\begin{array}{l}\text { Uncharacterized protein (por BLAST: } \\
\text { Myosin heavy chain / Purpureocillium } \\
\text { lilacinum com 69,7\% de identidade) }\end{array}$ \\
\hline Q14ST4 & 27,95 & 0 & 1 & 1 & Não & 429870 & Peptide synthetase \\
\hline
\end{tabular}

Tabela 24. Resultado das identificações das proteínas da banda C6 do BN-PAGE.

\begin{tabular}{|c|c|c|c|c|c|c|c|}
\hline Número de Acesso & Score & $\begin{array}{c}\text { Cobertura } \\
(\%)\end{array}$ & \# Peptídeos & $\begin{array}{c}\text { \# Peptídeos } \\
\text { Unicos }\end{array}$ & PTMs & $\begin{array}{c}\text { Massa } \\
\text { Média (Da) }\end{array}$ & Descrição (em inglês) \\
\hline O14402 & 142,56 & 4 & 5 & 4 & Sim & 107912 & Beta-1,3 exoglucanase \\
\hline A0A0G0AGG8 & 135,96 & 6 & 6 & 4 & Sim & 46231 & Mannanase \\
\hline A0A0F9XHQ5 & 134,97 & 9 & 6 & 6 & Sim & 48969 & Glucanase \\
\hline A0A0F9ZY32 & 114,01 & 4 & 3 & 2 & Sim & 107210 & Glucan 1,3-beta-glucosidase \\
\hline A0A0F9X2V9 & 105,51 & 4 & 2 & 2 & Sim & 53003 & Glucanase \\
\hline Q9P8P3 & 105,51 & 4 & 2 & 2 & Sim & 53216 & Exoglucanase 1 \\
\hline G8FPZ8 & 104,01 & 10 & 2 & 2 & Não & 14389 & Eliciting plant response-like protein \\
\hline M4T2Q5 & 101,87 & 6 & 3 & 1 & Sim & 47164 & Man5A \\
\hline P87258 & 98,50 & 5 & 2 & 2 & Não & 64534 & Beta-hexosaminidase \\
\hline A0A0G0A408 & 84,39 & 2 & 2 & 2 & Sim & 86623 & $\begin{array}{c}\text { Glycosyl hydrolase family 3 N terminal } \\
\text { domain-containing protein }\end{array}$ \\
\hline A0A0F9Y3W7 & 84,03 & 4 & 2 & 2 & Não & 41830 & $\begin{array}{c}\text { Uncharacterized protein (por BLAST: } \\
86,4 \% \text { de identidade e Cell wall protein } \\
\text { / T. reesei com 85,2\% de identidade) }\end{array}$ \\
\hline A0A0F9ZXC9 & 83,92 & 1 & 1 & 1 & Sim & 117541 & WSC domain-containing protein \\
\hline A0A0F9Y245 & 82,37 & 6 & 2 & 2 & Sim & 37299 & Alpha/beta hydrolase \\
\hline A0A0F9ZWP3 & 80,42 & 1 & 1 & 1 & Sim & 96970 & $\begin{array}{c}\text { Uncharacterized protein (por BLAST: } \\
\text { Carboxy terminal WSC domain- } \\
\text { containing protein / T. reesei com } \\
85,1 \% \text { de identidade) }\end{array}$ \\
\hline
\end{tabular}




\begin{tabular}{|c|c|c|c|c|c|c|c|}
\hline A0A0F9WYH5 & 77,48 & 4 & 1 & 1 & Não & 45007 & Cellulase \\
\hline A0A0G0ARJ7 & 77,08 & 4 & 1 & 1 & Não & 40277 & $\begin{array}{c}\text { Uncharacterized protein (por BLAST: } \\
\text { Glycoside hydrolase family 16 protein / } \\
\text { T. virens com 91,5\% de identidade) }\end{array}$ \\
\hline A0A0F9ZG17 & 66,37 & 5 & 1 & 1 & Sim & 37881 & Polygalacturonase \\
\hline B7ZEN3 & 66,37 & 4 & 1 & 1 & Sim & 38296 & Endopolygalacturonase \\
\hline Q599K8 & 39,59 & 1 & 1 & 1 & Não & 66255 & Glucoamylase \\
\hline A0A0G0A7Y5 & 39,59 & 1 & 1 & 1 & Não & 69967 & Glucoamylase \\
\hline
\end{tabular}

Tabela 25. Resultado das identificações das proteínas da banda C7 do BN-PAGE.

\begin{tabular}{|c|c|c|c|c|c|c|c|}
\hline Número de Acesso & Score & $\begin{array}{c}\text { Cobertura } \\
(\%)\end{array}$ & \# Peptídeos & $\begin{array}{l}\text { \# Peptídeos } \\
\text { Únicos }\end{array}$ & PTMs & $\begin{array}{c}\text { Massa } \\
\text { Média (Da) }\end{array}$ & Descrição (em inglês) \\
\hline Q9P8P3 & 183,30 & 20 & 11 & 2 & Sim & 53216 & Exoglucanase 1 \\
\hline A0A0F9X2V9 & 182,20 & 14 & 11 & 2 & Sim & 53003 & Glucanase \\
\hline A0A0F9XD50 & 160,92 & 13 & 9 & 9 & Sim & 59824 & Carboxylic ester hydrolase \\
\hline A0A0G0AGG8 & 146,99 & 12 & 11 & 8 & Sim & 46231 & Mannanase \\
\hline A0A0G0A4Q2 & 131,31 & 8 & 4 & 2 & Sim & 52710 & Alpha-L-arabinofuranosidase B \\
\hline A0A0F9Y245 & 125,30 & 11 & 4 & 4 & Sim & 37299 & Alpha/beta hydrolase \\
\hline A0A0F9WY34 & 111,44 & 7 & 3 & 3 & Sim & 66204 & $\begin{array}{l}\text { Uncharacterized protein (por BLAST: } \\
\text { Subtilisin-like protein / T. reesei com } \\
84,4 \% \text { de identidade) }\end{array}$ \\
\hline M4T2Q5 & 105,75 & 8 & 4 & 1 & Sim & 47164 & Man5A \\
\hline A0A0F9Y0Z9 & 89,54 & 5 & 4 & 2 & Sim & 51420 & Alpha-L-arabinofuranosidase B \\
\hline A0A0F9Y3W7 & 83,60 & 4 & 2 & 2 & Sim & 41830 & $\begin{array}{l}\text { Uncharacterized protein (por BLAST: } \\
\text { ECM33-like protein / T. reesei com } \\
\text { 86,4\% de identidade e Cell wall protein } \\
\text { / T. reesei com } 85,2 \% \text { de identidade) }\end{array}$ \\
\hline A0A0F9ZKA8 & 81,94 & 4 & 2 & 2 & Sim & 56280 & 1,3-beta-glucanosyltransferase \\
\hline A0A0G0A171 & 67,02 & 8 & 1 & 1 & Sim & 24024 & Endo-1,4-beta-xylanase \\
\hline
\end{tabular}




\begin{tabular}{|c|c|c|c|c|c|c|c|}
\hline A0A0G0AME2 & 63,23 & 4 & 1 & 1 & Sim & 33450 & $\begin{array}{c}\text { Uncharacterized protein (por BLAST: } \\
\text { Carbohydrate-binding module family } 1 \\
\text { protein / T. atroviride com } 82,4 \% \text { de } \\
\text { identidade) }\end{array}$ \\
\hline A0A0F9WYH5 & 58,78 & 4 & 1 & 1 & Não & 45007 & Cellulase \\
\hline A0A0F9XM06 & 57,14 & 6 & 1 & 1 & Sim & 24314 & $\begin{array}{l}\text { Uncharacterized protein (por BLAST: } \\
\text { Putative GPI anchored protein / } \\
\text { Ustilaginoidea virens com 58,2\% de } \\
\text { identidade e Expression library } \\
\text { immunization antigen } 1 / \text { Metarhizium } \\
\text { robertsii com } 60,7 \% \text { de identidade) }\end{array}$ \\
\hline A0A0F9XGP4 & 56,50 & 5 & 1 & 1 & Sim & 17231 & Acetylxylan esterase 2 \\
\hline A0A0F9X6R5 & 56,50 & 4 & 1 & 1 & Sim & 24196 & Acetylxylan esterase \\
\hline A0A0F9XP88 & 56,50 & 3 & 1 & 1 & Sim & 30201 & Acetylxylan esterase \\
\hline P79072 & 56,13 & 15 & 1 & 1 & Sim & 9028 & Hydrophobin \\
\hline A0A0F9XQN9 & 53,51 & 2 & 1 & 1 & Não & 25494 & $\begin{array}{c}\text { Uncharacterized protein (por BLAST: } \\
\text { Carbohydrate-binding domain, family } \\
\text { 9-like, subgroup / Pochonia } \\
\text { chlamydosporia com } 69,7 \% \text { de } \\
\text { identidade) }\end{array}$ \\
\hline A0A0F9XIA1 & 48,88 & 2 & 1 & 1 & Não & 74381 & Pro-kumamolisin \\
\hline A4V8W1 & 48,88 & 2 & 1 & 1 & Não & 74277 & Serin endopeptidase \\
\hline A0A0G0AQ41 & 48,74 & 0 & 1 & 1 & Não & 313265 & Ribosomal protein L19 \\
\hline A0A0F9ZMW7 & 41,42 & 3 & 1 & 1 & Sim & 48710 & Cell wall glucanase \\
\hline A0A0F9X878 & 37,84 & 1 & 1 & 1 & Não & 166523 & WSC domain-containing protein \\
\hline A0A0F9XNR6 & 32,51 & 2 & 1 & 1 & Sim & 50070 & $\begin{array}{l}\text { Uncharacterized protein (por BLAST: } \\
\text { Glycoside hydrolase family } 5 \text { protein / } \\
\text { T. virens com } 85,2 \% \text { de identidade) }\end{array}$ \\
\hline A0A0G0AED0 & 31,35 & 1 & 1 & 1 & Sim & 113509 & 5'-3' exoribonuclease 2 \\
\hline
\end{tabular}




\begin{tabular}{|c|c|c|c|c|c|c|c|}
\hline A0A0F9XV83 & 28,46 & 0 & 1 & 1 & Não & 161888 & $\begin{array}{c}\text { Uncharacterized protein (por BLAST: } \\
\text { Putative SNF2 family helicase/ATPase / } \\
\text { T. reesei com } 81,4 \% \text { de identidade) }\end{array}$ \\
\hline A0A0F9X8D8 & 28,46 & 1 & 1 & 1 & Não & 65836 & $\begin{array}{l}\text { Uncharacterized protein (por BLAST: } \\
\text { MFS general substrate transporter / } T \text {. } \\
\text { reesei com } 71,8 \% \text { de identidade) }\end{array}$ \\
\hline A0A0F9ZNT1 & 28,46 & 1 & 1 & 1 & Não & 72726 & $\begin{array}{l}\text { Uncharacterized protein (por BLAST: } \\
\text { Urea active transporter / T. reesei com } \\
88,9 \% \text { de identidade e Na+/proline } \\
\text { symporter / T. reesei com } 89,6 \% \text { de } \\
\text { identidade) }\end{array}$ \\
\hline A0A0F9XMY3 & 28,46 & 1 & 1 & 1 & Não & 83305 & $\begin{array}{c}\text { Uncharacterized protein (por BLAST: } \\
\text { Actin-like ATPase domain-containing } \\
\text { protein / T. reesei com } 99,0 \% \text { de } \\
\text { identidade) }\end{array}$ \\
\hline A0A0G0A262 & 28,46 & 1 & 1 & 1 & Não & 98504 & $\begin{array}{l}\text { Uncharacterized protein (por BLAST: } \\
\text { HET-domain-containing protein } / T \text {. } \\
\text { reesei com } 66,8 \% \text { de identidade) }\end{array}$ \\
\hline A0A0G0A4A0 & 28,46 & 1 & 1 & 1 & Não & 101009 & $\begin{array}{c}\text { Uncharacterized protein (por BLAST: } \\
\text { Ankyrin protein / T. virens com 37,7\% } \\
\text { de identidade e Serine protein kinase } \\
\text { Sky1 / Metarhizium guizhouense com } \\
\text { 35,9\% de identidade) }\end{array}$ \\
\hline A0A0G0A1I2 & 28,46 & 0 & 1 & 1 & Não & 297067 & $\begin{array}{l}\text { Uncharacterized protein (por BLAST: } \\
\text { HEAT repeat protein / T. reesei com } \\
89,5 \% \text { de identidade) }\end{array}$ \\
\hline A0A0F9X5W2 & 28,46 & 0 & 1 & 1 & Não & 326080 & Serine/threonine-protein kinase TEL1 \\
\hline A0A0F9Z848 & 28,39 & 1 & 1 & 1 & Não & 97705 & Trehalose 6-phosphate synthase \\
\hline A0A0F9X6U5 & 27,92 & 1 & 1 & 1 & Não & 132268 & $\begin{array}{l}\text { Uncharacterized protein (por BLAST: } \\
\text { Vegetative incompatibility protein }\end{array}$ \\
\hline
\end{tabular}




\begin{tabular}{|l|l|l|l|l|l|c|}
\hline & & & & & & $\begin{array}{c}\text { HET-E-1/ Madurella mycetomatis com } \\
33,5 \% \text { de identidade) }\end{array}$ \\
\hline
\end{tabular}

Tabela 26. Resultado das identificações das proteínas da banda X1 do BN-PAGE.

\begin{tabular}{|c|c|c|c|c|c|c|c|}
\hline Número de Acesso & Score & $\begin{array}{c}\text { Cobertura } \\
(\%)\end{array}$ & \# Peptídeos & $\begin{array}{c}\text { \# Peptídeos } \\
\text { Unicos }\end{array}$ & PTMs & $\begin{array}{c}\text { Massa } \\
\text { Média (Da) }\end{array}$ & Descrição (em inglês) \\
\hline A0A0G0A408 & 330,85 & 26 & 45 & 45 & Sim & 86623 & $\begin{array}{c}\text { Glycosyl hydrolase family } 3 \text { N terminal } \\
\text { domain-containing protein }\end{array}$ \\
\hline A0A0F9XL67 & 169,95 & 15 & 8 & 8 & Sim & 47504 & $\begin{array}{c}\text { Uncharacterized protein (por BLAST: } \\
\text { Aldose-1-epimerase / T. reesei com } \\
84,0 \% \text { de identidade) }\end{array}$ \\
\hline G8FPZ8 & 153,65 & 18 & 4 & 4 & Sim & 14389 & Eliciting plant response-like protein \\
\hline A0A0F9X224 & 143,25 & 9 & 5 & 5 & Sim & 62637 & $\begin{array}{c}\text { Uncharacterized protein (por BLAST: } \\
\text { Amidase / T. reesei com 93,1\% de } \\
\text { identidade) }\end{array}$ \\
\hline A0A0F9XCM6 & 73,38 & 1 & 1 & 1 & Sim & 106898 & $\begin{array}{c}\text { Uncharacterized protein (por BLAST: } \\
\text { protein / T. reesei com 85,9\% de } \\
\text { identidade) }\end{array}$ \\
\hline A0A0F9Y3W7 & 52,25 & 2 & 1 & 1 & Não & 41830 & $\begin{array}{c}\text { Uncharacterized protein (por BLAST: } \\
\text { ECM33-like protein / T. reesei com } \\
86,4 \% \text { de identidade e Cell wall protein } \\
\text { / T. reesei com 85,2\% de identidade) }\end{array}$ \\
\hline A0A0F9XRV0 & 44,74 & 1 & 1 & 1 & Não & 78113 & Chaperonin GroL \\
\hline A0A0F9XGP4 & 39,50 & 5 & 1 & 1 & Sim & 17231 & Acetylxylan esterase 2 \\
\hline A0A0F9X6R5 & 39,50 & 4 & 1 & 1 & Sim & 24196 & Acetylxylan esterase \\
\hline
\end{tabular}


Tabela 27. Resultado das identificações das proteínas da banda X2 do BN-PAGE.

\begin{tabular}{|c|c|c|c|c|c|c|c|}
\hline Número de Acesso & Score & $\begin{array}{c}\text { Cobertura } \\
(\%)\end{array}$ & \# Peptídeos & $\begin{array}{c}\text { \# Peptídeos } \\
\text { Únicos }\end{array}$ & PTMs & $\begin{array}{c}\text { Massa } \\
\text { Média (Da) }\end{array}$ & Descrição (em inglês) \\
\hline A0A0G0A408 & 255,69 & 19 & 29 & 29 & Sim & 86623 & $\begin{array}{c}\text { Glycosyl hydrolase family } 3 \text { N terminal } \\
\text { domain-containing protein }\end{array}$ \\
\hline A0A0F9X224 & 170,07 & 14 & 8 & 8 & Sim & 62637 & $\begin{array}{c}\text { Uncharacterized protein (por BLAST: } \\
\text { Amidase / } T \text {. reesei com 93,1\% de } \\
\text { identidade) }\end{array}$ \\
\hline A0A0G0A296 & 152,58 & 17 & 6 & 6 & Sim & 52046 & $\begin{array}{c}\text { Uncharacterized protein (por BLAST: } \\
\text { Glycoside hydrolase family 5 protein / } \\
\text { virens com 95,9\% de identidade) }\end{array}$ \\
\hline A0A0F9XP97 & 133,69 & 20 & 6 & 6 & Sim & 41622 & Actin \\
\hline A0A0G0AB19 & 133,43 & 7 & 5 & 5 & Sim & 89553 & Alpha-1,2-mannosidase \\
\hline P87258 & 128,92 & 9 & 5 & 5 & Sim & 64534 & Beta-hexosaminidase \\
\hline A0A0F9XL67 & 123,06 & 10 & 5 & 5 & Sim & 47504 & $\begin{array}{c}\text { Uncharacterized protein (por BLAST: } \\
\text { Aldose-1-epimerase / T. reesei com } \\
84,0 \% \text { de identidade) }\end{array}$ \\
\hline A0A0F9ZQQ1 & 91,85 & 4 & 2 & 2 & Não & 59499 & ATP synthase subunit alpha \\
\hline A0A0F9XF89 & 78,33 & 3 & 3 & 3 & Sim & 83087 & $\begin{array}{c}\text { Uncharacterized protein (por BLAST: } \\
\text { Glycoside hydrolase family 55 protein / } \\
\text { virens com 95,6\% de identidade) }\end{array}$ \\
\hline G8FPZ8 & 72,09 & 18 & 2 & 2 & Sim & 14389 & Eliciting plant response-like protein \\
\hline A0A0G0A9T1 & 69,58 & 12 & 1 & 1 & Sim & 11356 & Histone H4 \\
\hline A0A0G0A3D5 & 65,49 & 6 & 1 & 1 & Não & 17578 & Ubiquitin-40S ribosomal protein S27a \\
\hline H9BVC3 & 65,49 & 3 & 1 & 1 & Não & 29611 & Ubiquitin (Fragment) \\
\hline
\end{tabular}




\begin{tabular}{|c|c|c|c|c|c|c|c|}
\hline A0A0F9WV99 & 59,39 & 2 & 1 & 1 & Sim & 49579 & Tubulin beta chain \\
\hline A0A0F9Y245 & 58,32 & 3 & 1 & 1 & Sim & 37299 & Alpha/beta hydrolase \\
\hline A0A0G0ALL0 & 44,27 & 2 & 1 & 1 & Não & 50138 & Tubulin alpha chain \\
\hline Q71C08 & 41,97 & 5 & 1 & 1 & Não & 25238 & Translation elongation factor 1-alpha \\
\hline A0A0K0K9C4 & 41,97 & 4 & 1 & 1 & Não & 27021 & Translation elongation factor 1 -alpha \\
\hline A0A0F9Y3W7 & 41,35 & 2 & 1 & 1 & Sim & 41830 & $\begin{array}{l}\text { Uncharacterized protein (por BLAST: } \\
\text { ECM33-like protein / T. reesei com } \\
\text { 86,4\% de identidade e Cell wall protein } \\
\text { / T. reesei com } 85,2 \% \text { de identidade) }\end{array}$ \\
\hline A0A0F9WYH5 & 40,98 & 4 & 1 & 1 & Não & 45007 & Cellulase \\
\hline A0A0F9XBC8 & 36,25 & 3 & 1 & 1 & Não & 22707 & Histone $\mathrm{H} 3$ \\
\hline A0A0F9XJU5 & 36,25 & 1 & 1 & 1 & Não & 127500 & Telomerase reverse transcriptase \\
\hline A0A0F9XPU4 & 33,87 & 7 & 1 & 1 & Não & 14845 & Histone H2B \\
\hline A0A0G0A6L7 & 32,46 & 3 & 1 & 1 & Não & 29602 & 14-3-3 family protein \\
\hline A0A0F9XK23 & 32,46 & 3 & 1 & 1 & Não & 30483 & DNA damage checkpoint protein rad24 \\
\hline A0A0F9ZXP0 & 29,28 & 3 & 1 & 1 & Não & 37840 & $\begin{array}{l}\text { Uncharacterized protein (sem bons } \\
\text { alinhamentos por BLAST com proteínas } \\
\text { conhecidas) }\end{array}$ \\
\hline A0A0F9Y0X0 & 29,12 & 1 & 1 & 1 & Sim & 92791 & Beta-glucosidase \\
\hline
\end{tabular}

Tabela 28. Resultado das identificações das proteínas da banda X3 do BN-PAGE.

\begin{tabular}{|c|c|c|c|c|c|c|c|}
\hline Número de Acesso & Score & $\begin{array}{c}\text { Cobertura } \\
(\%)\end{array}$ & \# Peptídeos & $\begin{array}{c}\text { \# Peptídeos } \\
\text { Únicos }\end{array}$ & PTMs & $\begin{array}{c}\text { Massa } \\
\text { Média (Da) }\end{array}$ & Descrição (em inglês) \\
\hline A0A0G0A408 & 266,36 & 25 & 48 & 48 & Sim & 86623 & $\begin{array}{c}\text { Glycosyl hydrolase family } 3 \text { N terminal } \\
\text { domain-containing protein }\end{array}$ \\
\hline A0A0F9X224 & 212,20 & 32 & 21 & 21 & Sim & 62637 & $\begin{array}{c}\text { Uncharacterized protein (por BLAST: } \\
\text { Amidase / T. reesei com 93,1\% de } \\
\text { identidade) }\end{array}$ \\
\hline
\end{tabular}




\begin{tabular}{|c|c|c|c|c|c|c|c|}
\hline A0A0F9XL67 & 181,63 & 18 & 15 & 15 & Sim & 47504 & $\begin{array}{c}\text { Uncharacterized protein (por BLAST: } \\
\text { Aldose-1-epimerase / T. reesei com } \\
84,0 \% \text { de identidade) }\end{array}$ \\
\hline P87258 & 163,31 & 17 & 11 & 11 & Sim & 64534 & Beta-hexosaminidase \\
\hline A0A0G0ABI9 & 119,48 & 5 & 4 & 4 & Sim & 89553 & Alpha-1,2-mannosidase \\
\hline A0A0F9XFZ5 & 118,34 & 4 & 4 & 4 & Sim & 93346 & Alpha-glucuronidase \\
\hline A0A0G0A296 & 113,28 & 10 & 3 & 3 & Sim & 52046 & $\begin{array}{l}\text { Uncharacterized protein (por BLAST: } \\
\text { Glycoside hydrolase family } 5 \text { protein / } \\
\text { T. virens com } 95,9 \% \text { de identidade) }\end{array}$ \\
\hline A0A0F9Y0X0 & 107,40 & 5 & 4 & 4 & Sim & 92791 & Beta-glucosidase \\
\hline A0A0G0ARJ7 & 102,13 & 6 & 2 & 2 & Não & 40277 & $\begin{array}{l}\text { Uncharacterized protein (por BLAST: } \\
\text { Glycoside hydrolase family } 16 \text { protein / } \\
\text { T. virens com } 91,5 \% \text { de identidade) }\end{array}$ \\
\hline A0A0F9Y3W7 & 88,37 & 6 & 3 & 3 & Sim & 41830 & $\begin{array}{l}\text { Uncharacterized protein (por BLAST: } \\
\text { ECM33-like protein / T. reesei com } \\
\text { 86,4\% de identidade e Cell wall protein } \\
\text { / T. reesei com } 85,2 \% \text { de identidade) }\end{array}$ \\
\hline A0A0F9ZS41 & 87,83 & 2 & 3 & 3 & Não & 116867 & Acid trehalase \\
\hline A0A0G0AN43 & 84,57 & 5 & 2 & 2 & Sim & 51955 & Murein transglycosylase \\
\hline A0A0F9Y245 & 83,05 & 7 & 2 & 2 & Sim & 37299 & Alpha/beta hydrolase \\
\hline Q599K8 & 74,91 & 3 & 2 & 2 & Não & 66255 & Glucoamylase \\
\hline A0A0G0A7Y5 & 74,91 & 2 & 2 & 2 & Não & 69967 & Glucoamylase \\
\hline A0A0F9Y5T3 & 73,28 & 7 & 2 & 2 & Sim & 36156 & $\begin{array}{l}\text { Glyceraldehyde-3-phosphate } \\
\text { dehydrogenase }\end{array}$ \\
\hline A0A0F9XGP4 & 50,98 & 5 & 1 & 1 & Sim & 17231 & Acetylxylan esterase 2 \\
\hline A0A0F9X6R5 & 50,98 & 4 & 1 & 1 & Sim & 24196 & Acetylxylan esterase \\
\hline A0A0F9XP88 & 50,98 & 3 & 1 & 1 & Sim & 30201 & Acetylxylan esterase \\
\hline A0A0F9XMI8 & 49,23 & 2 & 1 & 1 & Não & 35711 & Glycosylhydrolase family $61-2$ \\
\hline A0A0F9XII5 & 38,67 & 1 & 1 & 1 & Não & 99019 & $\begin{array}{l}\text { Uncharacterized protein (por BLAST: } \\
\text { Glycoside hydrolase family } 2 \text { protein / }\end{array}$ \\
\hline
\end{tabular}




\begin{tabular}{|c|c|c|c|c|c|c|c|}
\hline & & & & & $\begin{array}{c}T . \text { virens com 92,5\% de identidade e } \\
\text { Exo-beta-D-glucosaminidase / T. virens } \\
\text { com 92,1\% de idenidade) }\end{array}$ \\
\hline A0A0F9X9K8 & 37,84 & 2 & 1 & 1 & Não & 48200 & $\begin{array}{c}\text { Uncharacterized protein (por BLAST: } \\
\text { Acid phosphatase-like protein / T. reesei } \\
\text { com 84,5\% de identidade) }\end{array}$ \\
\hline A0A0F9XF89 & 36,72 & 1 & 1 & 1 & Não & 83087 & $\begin{array}{c}\text { Uncharacterized protein (por BLAST: } \\
\text { Glycoside hydrolase family 55 protein / } \\
\text { T. virens com 95,6\% de identidade) }\end{array}$ \\
\hline A0A0F9XW90 & 33,02 & 2 & 1 & 1 & Sim & 47440 & CoA-transferase family III \\
\hline A0A0G0ALL6 & 29,21 & 1 & 1 & 1 & Não & 103984 & $\begin{array}{c}\text { Uncharacterized protein (por BLAST: } \\
\text { PABlinding protein / Pochonia } \\
\text { chlamydosporia com 67,6\% de } \\
\text { identidade) }\end{array}$ \\
\hline A0A0F9X368 & 28,78 & 2 & 1 & 1 & Não & 50399 & $\begin{array}{c}\text { Uncharacterized protein (por BLAST: } \\
\text { Ribosomal protein YmL35 / T. reesei } \\
\text { com 88,5\% de identidade) }\end{array}$ \\
\hline
\end{tabular}

Tabela 29. Resultado das identificações das proteínas da banda X4 do BN-PAGE.

\begin{tabular}{|c|c|c|c|c|c|c|c|}
\hline Número de Acesso & Score & $\begin{array}{c}\text { Cobertura } \\
(\%)\end{array}$ & \# Peptídeos & $\begin{array}{c}\text { \# Peptídeos } \\
\text { Únicos }\end{array}$ & PTMs & $\begin{array}{c}\text { Massa } \\
\text { Média (Da) }\end{array}$ & Descrição (em inglês) \\
\hline A0A0G0A408 & 279,75 & 25 & 40 & 40 & Sim & 86623 & $\begin{array}{c}\text { Glycosyl hydrolase family 3 N terminal } \\
\text { domain-containing protein }\end{array}$ \\
\hline A0A0F9X224 & 217,16 & 23 & 12 & 12 & Sim & 62637 & $\begin{array}{c}\text { Uncharacterized protein (por BLAST: } \\
\text { Amidase / T. reesei com 93,1\% de } \\
\text { identidade) }\end{array}$ \\
\hline P87258 & 192,96 & 19 & 13 & 13 & Sim & 64534 & Beta-hexosaminidase \\
\hline
\end{tabular}




\begin{tabular}{|c|c|c|c|c|c|c|c|}
\hline A0A0F9XL67 & 187,88 & 22 & 15 & 15 & Sim & 47504 & $\begin{array}{c}\text { Uncharacterized protein (por BLAST: } \\
\text { Aldose-1-epimerase / T. reesei com } \\
84,0 \% \text { de identidade) }\end{array}$ \\
\hline A0A0G0A7Y5 & 187,40 & 15 & 17 & 17 & Sim & 69967 & Glucoamylase \\
\hline A0A0F9Y0X0 & 164,24 & 9 & 7 & 7 & Sim & 92791 & Beta-glucosidase \\
\hline A0A0F9ZS41 & 154,57 & 8 & 9 & 9 & Sim & 116867 & Acid trehalase \\
\hline A0A0F9X3Z8 & 145,15 & 8 & 9 & 9 & Sim & 88742 & Catalase-peroxidase \\
\hline A0A0G0ARJ7 & 129,57 & 8 & 3 & 3 & Não & 40277 & $\begin{array}{l}\text { Uncharacterized protein (por BLAST: } \\
\text { Glycoside hydrolase family } 16 \text { protein / } \\
\text { T. virens com } 91,5 \% \text { de identidade) }\end{array}$ \\
\hline A0A0F9ZH76 & 128,58 & 5 & 3 & 3 & Sim & 79362 & Purple acid phosphatase \\
\hline A0A0F9XFZ5 & 113,75 & 4 & 4 & 4 & Não & 93346 & Alpha-glucuronidase \\
\hline A0A0G0AN43 & 113,15 & 7 & 3 & 3 & Sim & 51955 & Murein transglycosylase \\
\hline A0A0F9Y245 & 112,04 & 11 & 3 & 3 & Sim & 37299 & Alpha/beta hydrolase \\
\hline A0A0F9XMI8 & 97,63 & 7 & 3 & 3 & Sim & 35711 & Glycosylhydrolase family $61-2$ \\
\hline A0A0F9Y3W7 & 92,86 & 6 & 3 & 3 & Sim & 41830 & $\begin{array}{l}\text { Uncharacterized protein (por BLAST: } \\
\text { ECM33-like protein / T. reesei com } \\
\text { 86,4\% de identidade e Cell wall protein } \\
\text { / T. reesei com } 85,2 \% \text { de identidade) }\end{array}$ \\
\hline A0A0F9XRU0 & 90,48 & 2 & 2 & 2 & Não & 121002 & Glycosyl hydrolase family 92 \\
\hline A0A0F9ZXC9 & 88,97 & 2 & 2 & 2 & Sim & 117541 & WSC domain-containing protein \\
\hline G8FPZ8 & 67,12 & 10 & 1 & 1 & Não & 14389 & Eliciting plant response-like protein \\
\hline A0A0F9X9K8 & 38,08 & 2 & 1 & 1 & Não & 48200 & $\begin{array}{l}\text { Uncharacterized protein (por BLAST: } \\
\text { Acid phosphatase-like protein / T. reesei } \\
\text { com } 84,5 \% \text { de identidade) }\end{array}$ \\
\hline A0A0G0A2A8 & 37,06 & 7 & 1 & 1 & Não & 17519 & $\begin{array}{c}\text { Uncharacterized protein (sem bons } \\
\text { alinhamentos por BLAST com proteínas } \\
\text { conhecidas) }\end{array}$ \\
\hline A0A0F9XX62 & 36,62 & 3 & 1 & 1 & Sim & 59632 & 3-phytase A \\
\hline A0A0F9ZVD3 & 36,13 & 2 & 1 & 1 & Não & 84387 & Beta-glucosidase \\
\hline
\end{tabular}




\begin{tabular}{|c|c|c|c|c|c|c|c|}
\hline A0A0F9X368 & 35,61 & 2 & 1 & 1 & Sim & 50399 & $\begin{array}{c}\text { Uncharacterized protein (por BLAST: } \\
\text { Ribosomal protein YmL35 / T. reesei } \\
\text { com 88,5\% de identidade) }\end{array}$ \\
\hline A0A0F9XW90 & 34,93 & 2 & 1 & 1 & Sim & 47440 & CoA-transferase family III \\
\hline A0A0G0A6L8 & 34,73 & 1 & 1 & 1 & Não & 83322 & Glycosyl hydrolase \\
\hline A0A0F9X329 & 28,61 & 3 & 1 & 1 & Não & 26785 & $\begin{array}{c}\text { Uncharacterized protein (sem bons } \\
\text { alinhamentos por BLAST com proteínas } \\
\text { conhecidas) }\end{array}$ \\
\hline
\end{tabular}

Tabela 30. Resultado das identificações das proteínas da banda X5 do BN-PAGE.

\begin{tabular}{|c|c|c|c|c|c|c|c|}
\hline Número de Acesso & Score & $\begin{array}{c}\text { Cobertura } \\
(\boldsymbol{\%})\end{array}$ & \# Peptídeos & $\begin{array}{c}\text { \# Peptídeos } \\
\text { Únicos }\end{array}$ & PTMs & $\begin{array}{c}\text { Massa } \\
\text { Média (Da) }\end{array}$ & Descrição (em inglês) \\
\hline A0A0G0A408 & 289,03 & 24 & 36 & 36 & Sim & 86623 & $\begin{array}{c}\text { Glycosyl hydrolase family } 3 \text { N terminal } \\
\text { domain-containing protein }\end{array}$ \\
\hline A0A0F9ZVD3 & 266,41 & 19 & 21 & 21 & Sim & 84387 & Beta-glucosidase \\
\hline A0A0F9ZS41 & 229,90 & 14 & 21 & 21 & Sim & 116867 & Acid trehalase \\
\hline A0A0F9XL67 & 187,15 & 15 & 12 & 12 & Sim & 47504 & $\begin{array}{c}\text { Uncharacterized protein (por BLAST: } \\
\text { Aldose-1-epimerase / T. reesei com } \\
84,0 \% \text { de identidade) }\end{array}$ \\
\hline Q599K8 & 163,61 & 9 & 6 & 6 & Não & 66255 & Glucoamylase \\
\hline A0A0G0A7Y5 & 163,31 & 8 & 6 & 6 & Não & 69967 & Glucoamylase \\
\hline A0A0G0ARJ7 & 152,18 & 10 & 4 & 4 & Não & 40277 & $\begin{array}{c}\text { Uncharacterized protein (por BLAST: } \\
\text { T. virens com 91,5\% de identidade) }\end{array}$ \\
\hline A0A0F9XFZ5 & 136,50 & 4 & 4 & 4 & Sim & 93346 & Alpha-glucuronidase \\
\hline O14402 & 126,80 & 3 & 2 & 2 & Sim & 107912 & Beta-1,3 exoglucanase \\
\hline A0A0G0AN43 & 123,54 & 7 & 3 & 3 & Sim & 51955 & Murein transglycosylase \\
\hline
\end{tabular}




\begin{tabular}{|c|c|c|c|c|c|c|c|}
\hline A0A0F9Y0X0 & 117,99 & 4 & 3 & 3 & Sim & 92791 & Beta-glucosidase \\
\hline A0A0F9ZH76 & 112,47 & 5 & 3 & 3 & Sim & 79362 & Purple acid phosphatase \\
\hline A0A0F9X224 & 112,06 & 6 & 3 & 3 & Sim & 62637 & $\begin{array}{c}\text { Uncharacterized protein (por BLAST: } \\
\text { Amidase / T. reesei com 93,1\% de } \\
\text { identidade) }\end{array}$ \\
\hline G8FPZ8 & 108,61 & 18 & 2 & 2 & Sim & 14389 & Eliciting plant response-like protein \\
\hline A0A0F9ZDV4 & 104,65 & 3 & 2 & 2 & Sim & 105456 & Beta-mannosidase \\
\hline A0A0F9ZXC9 & 94,94 & 2 & 2 & 2 & Sim & 117541 & WSC domain-containing protein \\
\hline A0A0F9XMI8 & 94,81 & 4 & 2 & 2 & Não & 35711 & Glycosylhydrolase family $61-2$ \\
\hline A0A0F9XFJ7 & 87,32 & 3 & 2 & 2 & Sim & 63621 & $\begin{array}{l}\text { Uncharacterized protein (por BLAST: } \\
\text { Glycoside hydrolase family } 71 \text { protein / } \\
\text { T. virens com } 89,9 \% \text { de identidade) }\end{array}$ \\
\hline A0A0F9Y245 & 84,67 & 7 & 2 & 2 & Sim & 37299 & Alpha/beta hydrolase \\
\hline A0A0F9Y3W7 & 84,28 & 4 & 2 & 2 & Sim & 41830 & $\begin{array}{l}\text { Uncharacterized protein (por BLAST: } \\
\text { ECM33-like protein / T. reesei com } \\
\text { 86,4\% de identidade e Cell wall protein } \\
\text { / T. reesei com } 85,2 \% \text { de identidade) }\end{array}$ \\
\hline A0A0G0A6L8 & 76,90 & 2 & 2 & 2 & Não & 83322 & Glycosyl hydrolase \\
\hline A0A0F9XHQ5 & 51,17 & 3 & 1 & 1 & Sim & 48969 & Glucanase \\
\hline A0A0F9XII5 & 49,74 & 1 & 1 & 1 & Não & 99019 & $\begin{array}{l}\text { Uncharacterized protein (por BLAST: } \\
\text { Glycoside hydrolase family } 2 \text { protein / } \\
\text { T. virens com } 92,5 \% \text { de identidade e } \\
\text { Exo-beta-D-glucosaminidase / T. virens } \\
\text { com } 92,1 \% \text { de idenidade) }\end{array}$ \\
\hline A0A0F9XMG1 & 47,79 & 1 & 1 & 1 & Não & 83516 & Beta-glucosidase \\
\hline A0A0F9XQN9 & 37,80 & 2 & 1 & 1 & Não & 25494 & $\begin{array}{c}\text { Uncharacterized protein (por BLAST: } \\
\text { Carbohydrate-binding domain, family } \\
\text { 9-like, subgroup / Pochonia } \\
\text { chlamydosporia com } 69,7 \% \text { de } \\
\text { identidade) }\end{array}$ \\
\hline
\end{tabular}


Tabela 31. Resultado das identificações das proteínas da banda X6 do BN-PAGE.

\begin{tabular}{|c|c|c|c|c|c|c|c|}
\hline Número de Acesso & Score & $\begin{array}{c}\text { Cobertura } \\
(\%)\end{array}$ & \# Peptídeos & $\begin{array}{c}\text { \# Peptídeos } \\
\text { Únicos }\end{array}$ & PTMs & $\begin{array}{c}\text { Massa } \\
\text { Média (Da) }\end{array}$ & Descrição (em inglês) \\
\hline A0A0F9XL67 & 168,45 & 19 & 11 & 11 & Sim & 47504 & $\begin{array}{c}\text { Uncharacterized protein (por BLAST: } \\
\text { Aldose-1-epimerase / T. reesei com } \\
84,0 \% \text { de identidade) }\end{array}$ \\
\hline A0A0G0A4N5 & 167,36 & 8 & 8 & 8 & Sim & 105976 & $\begin{array}{c}\text { Uncharacterized protein (por BLAST: } \\
\text { Glycoside hydrolase family 2 protein / } \\
\text { virens com 88,1\% de identidade) }\end{array}$ \\
\hline A0A0F9X2V9 & 156,86 & 9 & 7 & 7 & Sim & 53003 & Glucanase \\
\hline A0A0F9Y245 & 146,94 & 13 & 5 & 5 & Sim & 37299 & Alpha/beta hydrolase \\
\hline A0A0F9ZVD3 & 144,98 & 6 & 4 & 4 & Sim & 84387 & Beta-glucosidase \\
\hline A0A0G0ARJ7 & 138,94 & 8 & 3 & 3 & Não & 40277 & $\begin{array}{c}\text { Uncharacterized protein (por BLAST: } \\
\text { Glycoside hydrolase family 16 protein / } \\
\text { virens com 91,5\% de identidade) }\end{array}$ \\
\hline A0A0G0AN43 & 133,52 & 7 & 3 & 3 & Sim & 51955 & Murein transglycosylase \\
\hline A0A0F9ZS41 & 129,84 & 6 & 5 & 5 & Sim & 116867 & Acid trehalase \\
\hline A0A0F9ZH76 & 126,77 & 5 & 3 & 3 & Sim & 79362 & Purple acid phosphatase \\
\hline A0A0G0A4Q2 & 112,03 & 6 & 2 & 2 & Sim & 52710 & Alpha-L-arabinofuranosidase B \\
\hline A0A0G0A408 & 109,02 & 9 & 6 & 6 & Sim & 86623 & $\begin{array}{c}\text { Glycosyl hydrolase family 3 N terminal } \\
\text { domain-containing protein }\end{array}$ \\
\hline A0A0F9Y3W7 & 97,90 & 6 & 3 & 3 & Sim & 41830 & $\begin{array}{c}\text { Uncharacterized protein (por BLAST: } \\
\text { ECM33-like protein / T. reesei com } \\
\text { / }\end{array}$ \\
\hline A0A0 reesei com 85,2\% de identidade)
\end{tabular}




\begin{tabular}{|c|c|c|c|c|c|c|c|}
\hline A0A0F9XRV7 & 91,15 & 3 & 3 & 3 & Não & 101498 & Peptidase \\
\hline Q599K8 & 74,32 & 3 & 2 & 2 & Não & 66255 & Glucoamylase \\
\hline A0A0G0A7Y5 & 74,32 & 2 & 2 & 2 & Não & 69967 & Glucoamylase \\
\hline A0A0F9XKY7 & 60,76 & 3 & 1 & 1 & Sim & 30568 & $\begin{array}{l}\text { Uncharacterized protein (por BLAST: } \\
\text { Carbohydrate esterase family } 5 \text { protein / } \\
\text { T. reesei com } 91,7 \% \text { de identidade) }\end{array}$ \\
\hline A0A0G0A385 & 52,16 & 3 & 1 & 1 & Sim & 51519 & $\begin{array}{l}\text { Uncharacterized protein (por BLAST: } \\
\text { Phosphoglycerate mutase-like protein / } \\
\text { T. reesei com } 82,8 \% \text { de identidade) }\end{array}$ \\
\hline A0A0F9XIJ9 & 50,78 & 1 & 1 & 1 & Não & 69828 & Lysophospholipase \\
\hline A0A0F9XP97 & 47,83 & 3 & 1 & 1 & Não & 41622 & Actin \\
\hline A0A0F9XGP4 & 47,02 & 5 & 1 & 1 & Sim & 17231 & Acetylxylan esterase 2 \\
\hline A0A0F9X6R5 & 47,02 & 4 & 1 & 1 & Sim & 24196 & Acetylxylan esterase \\
\hline A0A0F9XP88 & 47,02 & 3 & 1 & 1 & Sim & 30201 & Acetylxylan esterase \\
\hline A0A0F9XMI8 & 44,62 & 2 & 1 & 1 & Não & 35711 & Glycosylhydrolase family $61-2$ \\
\hline A0A0F9X9K8 & 41,20 & 2 & 1 & 1 & Não & 48200 & $\begin{array}{l}\text { Uncharacterized protein (por BLAST: } \\
\text { Acid phosphatase-like protein / T. reesei } \\
\text { com } 84,5 \% \text { de identidade) }\end{array}$ \\
\hline A0A0F9XQN9 & 40,23 & 2 & 1 & 1 & Não & 25494 & $\begin{array}{c}\text { Uncharacterized protein (por BLAST: } \\
\text { Carbohydrate-binding domain, family } \\
\text { 9-like, subgroup / Pochonia } \\
\text { chlamydosporia com } 69,7 \% \text { de } \\
\text { identidade) }\end{array}$ \\
\hline A0A0F9ZKA8 & 36,21 & 2 & 1 & 1 & Sim & 56280 & 1,3-beta-glucanosyltransferase \\
\hline A0A0F9ZZN6 & 36,21 & 1 & 1 & 1 & Sim & 57215 & 1,3-beta-glucanosyltransferase \\
\hline A0A0F9XQD6 & 35,50 & 2 & 1 & 1 & Sim & 85548 & $\begin{array}{l}\text { Uncharacterized protein (por BLAST: } \\
\text { Glycoside hydrolase family } 95 \text { protein / } \\
\text { T. virens com } 93,7 \% \text { de identidade) } \\
\end{array}$ \\
\hline A0A0G0AED0 & 30,92 & 1 & 1 & 1 & Sim & 113509 & 5'-3' exoribonuclease 2 \\
\hline A0A0F9Z848 & 30,72 & 1 & 1 & 1 & Não & 97705 & Trehalose 6-phosphate synthase \\
\hline
\end{tabular}




\begin{tabular}{|c|c|c|c|c|c|c|c|}
\hline A0A0F9XP75 & 30,02 & 2 & 1 & 1 & Não & 31531 & $\begin{array}{c}\text { Uncharacterized protein (por BLAST: } \\
\text { Glycoside hydrolase family 16 protein / } \\
\text { T. virens com } 88,4 \% \text { de identidade) }\end{array}$ \\
\hline
\end{tabular}

Tabela 32. Resultado das identificações das proteínas da banda X7 do BN-PAGE.

\begin{tabular}{|c|c|c|c|c|c|c|c|}
\hline Número de Acesso & Score & $\begin{array}{c}\text { Cobertura } \\
(\%)\end{array}$ & \# Peptídeos & $\begin{array}{c}\text { \# Peptídeos } \\
\text { Unicos }\end{array}$ & PTMs & $\begin{array}{c}\text { Massa } \\
\text { Média (Da) }\end{array}$ & Descrição (em inglês) \\
\hline A0A0G0A4Q2 & 167,26 & 11 & 6 & 4 & Sim & 52710 & Alpha-L-arabinofuranosidase B \\
\hline A0A0F9XP88 & 138,66 & 10 & 7 & 7 & Sim & 30201 & Acetylxylan esterase \\
\hline A0A0F9Y0Z9 & 138,16 & 5 & 7 & 5 & Sim & 51420 & Alpha-L-arabinofuranosidase B \\
\hline A0A0F9ZZN6 & 132,31 & 9 & 7 & 5 & Sim & 57215 & 1,3-beta-glucanosyltransferase \\
\hline A0A0F9Y245 & 125,55 & 11 & 4 & 4 & Sim & 37299 & Alpha/beta hydrolase \\
\hline A0A0F9XL67 & 113,51 & 9 & 5 & 5 & Sim & 47504 & $\begin{array}{c}\text { Uncharacterized protein (por BLAST: } \\
\text { Aldose-1-epimerase / T. reesei com } \\
84,0 \% \text { de identidade) }\end{array}$ \\
\hline A0A0G0AN43 & 102,09 & 7 & 3 & 3 & Sim & 51955 & Murein transglycosylase \\
\hline A0A0F9X2V9 & 94,86 & 3 & 2 & 2 & Sim & 53003 & Glucanase \\
\hline A0A0F9Y3W7 & 94,34 & 6 & 3 & 3 & Sim & 41830 & $\begin{array}{c}\text { Uncharacterized protein (por BLAST: } \\
\text { E6,4\% de identidade e Cell wall protein } \\
\text { / T. reesei com 85,2\% de identidade) }\end{array}$ \\
\hline A0A0F9ZKA8 & 92,44 & 6 & 3 & 1 & Sim & 56280 & 1,3-beta-glucanosyltransferase \\
\hline G8FPZ8 & 83,98 & 10 & 2 & 2 & Não & 14389 & Eliciting plant response-like protein \\
\hline A0A0F9X6H8 & 83,96 & 7 & 4 & 4 & Sim & 76515 & Glutaminase A \\
\hline A0A0G0AME2 & 72,31 & 4 & 1 & 1 & Sim & 33450 & $\begin{array}{c}\text { Uncharacterized protein (por BLAST: } \\
\text { Carbohydrate-binding module family 1 } \\
\text { protein / T. atroviride com 82,4\% de } \\
\text { identidade) }\end{array}$ \\
\hline
\end{tabular}




\begin{tabular}{|c|c|c|c|c|c|c|c|}
\hline A0A0G0ARJ7 & 63,87 & 6 & 2 & 2 & Não & 40277 & $\begin{array}{c}\text { Uncharacterized protein (por BLAST: } \\
\text { Glycoside hydrolase family 16 protein / } \\
\text { T. virens com 91,5\% de identidade) }\end{array}$ \\
\hline A0A0F9ZMW7 & 63,55 & 3 & 1 & 1 & Sim & 48710 & Cell wall glucanase \\
\hline A0A0F9ZVD3 & 58,82 & 3 & 1 & 1 & Sim & 84387 & Beta-glucosidase \\
\hline A0A0F9XIJ9 & 56,99 & 1 & 1 & 1 & Não & 69828 & Lysophospholipase \\
\hline A0A0F9XKY7 & 56,88 & 3 & 1 & 1 & Sim & 30568 & $\begin{array}{c}\text { Uncharacterized protein (por BLAST: } \\
\text { Carbohydrate esterase family 5 protein / } \\
\text { T. reesei com 91,7\% de identidade) }\end{array}$ \\
\hline A0A0F9X878 & 49,42 & 1 & 1 & 1 & Sim & 166523 & WSC domain-containing protein \\
\hline A0A0F9XQN9 & 49,02 & 2 & 1 & 1 & Não & 25494 & $\begin{array}{c}\text { Uncharacterized protein (por BLAST: } \\
\text { Carbohydrate-binding domain, family } \\
\text { 9-like, subgroup / Pochonia } \\
\text { chlamydosporia com 69,7\% de } \\
\text { identidade) }\end{array}$ \\
\hline A0A0F9XLM2 & 48,58 & 2 & 1 & 1 & Não & 61855 & FAD binding domain-containing protein \\
\hline A0A0G0A171 & 46,28 & 8 & 1 & 1 & Não & 24024 & Endo-1,4-beta-xylanase \\
\hline A0A0F9XCV0 & 41,24 & 2 & 1 & 1 & Não & 42076 & Glycosylhydrolase family 18-1 \\
\hline A0A0F9XMI8 & 38,91 & 2 & 1 & 1 & Não & 35711 & Glycosylhydrolase family 61-2 \\
\hline A0A0F9X9K8 & 38,90 & 2 & 1 & 1 & Não & 48200 & $\begin{array}{c}\text { Uncharacterized protein (por BLAST: } \\
\text { Acid phosphatase-like protein / T. reesei } \\
\text { com 84,5\% de identidade) }\end{array}$ \\
\hline Q599K8 & 37,53 & 1 & 1 & 1 & Não & 66255 & Glucoamylase \\
\hline A0A0F9XW90 & 31,58 & 2 & 1 & 1 & Sim & 47440 & CoA-transferase family III \\
\hline
\end{tabular}




\section{9) Bibliografia}

ADNEY, W. S. et al. Probing the role of N-linked glycans in the stability and activity of fungal cellobiohydrolases by mutational analysis. Cellulose, v. 16, n. 4, p. 699-709, 2009.

ADRIO, J. L.; DEMAIN, A. L. Microbial enzymes: tools for biotechnological processes. Biomolecules, v. 4, n. 1, p. 117-139, 2014.

AHNERT, S. E. et al. Principles of assembly reveal a periodic table of protein complexes. Science, v. 350, n. 6266, p. aaa2245-aaa2245, 11 dez. 2015.

AMORIM, H. V. et al. Scientific challenges of bioethanol production in Brazil. Applied Microbiology and Biotechnology, v. 91, n. 5, p. 1267-1275, 2011.

ARANTES, V.; SADDLER, J. N. Access to cellulose limits the efficiency of enzymatic hydrolysis: the role of amorphogenesis. Biotechnology for Biofuels, v. 3, n. 1, p. 4, 2010.

ARMENGAUD, J. et al. Exoproteomics: exploring the world around biological systems. Expert Review of Proteomics, v. 9, n. 5, p. 561-575, 9 out. 2012.

ARMSTRONG, Z. et al. Biocatalysts for biomass deconstruction from environmental genomics. Current Opinion in Chemical Biology, v. 29, p. 18-25, dez. 2015.

ARO, N.; PAKULA, T.; PENTTILÄ, M. Transcriptional regulation of plant cell wall degradation by filamentous fungi. FEMS Microbiology Reviews, v. 29, n. 4, p. 719739 , set. 2005.

BENÍTEZ, T. et al. Biocontrol mechanisms of Trichoderma strains. International Microbiology: the official journal of the Spanish Society for Microbiology, v. 7, n. 4, p. 249-60, dez. 2004.

BIANCO, L.; PERROTTA, G. Methodologies and perspectives of proteomics applied to filamentous fungi: From sample preparation to secretome analysis. International Journal of Molecular Sciences, v. 16, n. 3, p. 5803-5829, 2015.

BIELY, P. et al. Trichoderma reesei XYN VI - A novel appendage-dependent eukaryotic glucuronoxylan hydrolase. FEBS Journal, v. 281, n. 17, p. 3894-3903, 2014.

BIELY, P.; PULS, J.; SCHNEIDER, H. Acetyl xylan esterases in fungal cellulolytic systems. FEBS Letters, v. 186, n. 1, p. 80-84, 1 jul. 1985.

BINZ, P.-A. et al. Guidelines for reporting the use of mass spectrometry informatics in proteomics. Nature Biotechnology, v. 26, n. 8, p. 862, 2008.

BLUM, H.; BEIER, H.; GROSS, H. J. Improved silver staining of plant proteins, RNA and DNA in polyacrylamide gels. Electrophoresis, v. 8, n. 2, p. 93-99, 1987.

BONAZZA, K. et al. The fungal cerato-platanin protein EPL1 forms highly ordered layers at hydrophobic/hydrophilic interfaces. Soft Matter, v. 11, n. 9, p. 1723-1732, 2015.

BORNSCHEUER, U. T. Microbial carboxyl esterases: Classification, properties and application in biocatalysis. FEMS Microbiology Reviews, v. 26, n. 1, p. 73-81, 2002.

BOUWS, H.; WATTENBERG, A.; ZORN, H. Fungal secretomes-nature's toolbox for white biotechnology. Applied Microbiology and Biotechnology, v. 80, n. 3, p. 381-388, 
18 set. 2008 .

BROWN, N. A.; RIES, L. N. A.; GOLDMAN, G. H. How nutritional status signalling coordinates metabolism and lignocellulolytic enzyme secretion. Fungal Genetics and Biology, v. 72, p. 48-63, nov. 2014.

CABIB, E. et al. Crh1p and Crh2p are required for the cross-linking of chitin to beta(16)glucan in the Saccharomyces cerevisiae cell wall. Molecular Microbiology, v. 63, n. 3, p. 921-935, fev. 2007.

CACCIA, D. et al. Bioinformatics tools for secretome analysis. Biochimica et Biophysica Acta (BBA) - Proteins and Proteomics, v. 1834, n. 11, p. 2442-2453, nov. 2013.

CANDIANO, G. et al. Blue silver: A very sensitive colloidal Coomassie G-250 staining for proteome analysis. Electrophoresis, v. 25, n. 9, p. 1327-1333, 2004.

CANILHA, L. et al. Bioconversion of Sugarcane Biomass into Ethanol: An Overview about Composition, Pretreatment Methods, Detoxification of Hydrolysates, Enzymatic Saccharification, and Ethanol Fermentation. Journal of Biomedicine and Biotechnology, v. 2012, p. 1-15, 2012.

CANTAREL, B. L. et al. The Carbohydrate-Active EnZymes database (CAZy): an expert resource for Glycogenomics. Nucleic Acids Research, v. 37, n. Database issue, p. D2338, jan. 2009.

CAO, Y.; ZHAO, J.; XIONG, Y. L. Coomassie Brilliant Blue-binding: a simple and effective method for the determination of water-insoluble protein surface hydrophobicity. Analytical Methods, v. 8, n. 4, p. 790-795, 2016.

CARR, S. et al. The need for guidelines in publication of peptide and protein identification data: Working Group on Publication Guidelines for Peptide and Protein Identification Data. Molecular \& Cellular Proteomics, v. 3, n. 6, p. 531-533, 2004.

CARRERAS-VILLASENOR， N.; SANCHEZ-ARREGUIN， J. A.; HERRERAESTRELLA, A. H. Trichoderma: sensing the environment for survival and dispersal. Microbiology, v. 158, n. 1, p. 3-16, 1 jan. 2012.

CHAMBERGO, F. S.; VALENCIA, E. Y. Fungal biodiversity to biotechnology. Applied Microbiology and Biotechnology, p. 1-11, 2016.

CHET, I. et al. Regulation of two homodimer hexosaminidases in the mycoparasitic fungus Trichoderma asperellum by glucosamine. Current Genetics, v. 45, n. 4, p. 205213, 1 abr. 2004.

CHIBA, S. Molecular mechanism in $\alpha$-glucosidase and glucoamylase. Bioscience, Biotechnology, and Biochemistry, v. 61, n. 8, p. 1233-1239, 12 jan. 1997.

CHU, S.; MAJUMDAR, A. Opportunities and challenges for a sustainable energy future. Nature, v. 488, n. 7411, p. 294-303, 15 ago. 2012.

CORTÁZAR, A. R. et al. SECRETOOL: integrated secretome analysis tool for fungi. Amino Acids, v. 46, n. 2, p. 471-473, 27 fev. 2014.

COSERI, S. Cellulose: To depolymerize... or not to? Biotechnology Advances, 2017.

COURNOYER, B.; FAURE, D. Radiation and functional specialization of the family-3 glycoside hydrolases. Journal of molecular microbiology and biotechnology, v. 5, n. 3, p. 190-8, 2003. 
COX, J.; MANN, M. Quantitative, High-Resolution Proteomics for Data-Driven Systems Biology. Annual Review of Biochemistry, v. 80, n. 1, p. 273-299, 7 jul. 2011.

DA SILVA, A. J. et al. Blue native-PAGE analysis of Trichoderma harzianum secretome reveals cellulases and hemicellulases working as multienzymatic complexes. Proteomics, v. 12, n. 17, p. 2729-2738, 2012.

DA SILVA, A. J. et al. Secretomic Analysis Reveals Multi-Enzymatic Complexes in Trichoderma reesei Grown in Media Containing Lactose or Galactose. BioEnergy Research, v. 8, n. 4, p. 1906-1911, 3 dez. 2015.

DAHER, F. B.; BRAYBROOK, S. A. How to let go: pectin and plant cell adhesion. Frontiers in Plant Science, v. 6, n. July, p. 1-8, 2015.

DAVIES, G.; HENRISSAT, B. Structures and mechanisms of glycosyl hydrolases. Structure, v. 3, n. 9, p. 853-9, 15 set. 1995.

DE CASTRO, A. M. et al. Trichoderma harzianum IOC-4038: A Promising Strain for the Production of a Cellulolytic Complex with Significant $\beta$-Glucosidase Activity from Sugarcane Bagasse Cellulignin. Applied Biochemistry and Biotechnology, v. 162, n. 7, p. 2111-2122, 2010.

DE LA CRUZ, J. et al. A novel endo-beta-1,3-glucanase, BGN13.1, involved in the mycoparasitism of Trichoderma harzianum. Journal of Bacteriology, v. 177, n. 23, p. 6937-45, dez. 1995.

DE OLIVEIRA, J. M. P. F.; DE GRAAFF, L. H. Proteomics of industrial fungi: Trends and insights for biotechnology. Applied Microbiology and Biotechnology, v. 89, n. 2, p. 225-237, 2011.

DE PAULA SILVEIRA, F. Q. et al. A new xylanase from a Trichoderma harzianum strain. Journal of Industrial Microbiology and Biotechnology, v. 23, n. 1, p. 682-5, jul. 1999.

DEUTSCH, E. W. et al. Human Proteome Project Mass Spectrometry Data Interpretation Guidelines 2.1. Journal of Proteome Research, v. 15, n. 11, p. 3961-3970, 2016.

DHAWAN, S.; KAUR, J. Microbial mannanases: an overview of production and applications. Critical Reviews in Biotechnology, v. 27, n. 4, p. 197-216, 2007.

DO VALE, L. H. F. et al. Secretome analysis of the fungus Trichoderma harzianum grown on cellulose. Proteomics, v. 12, n. 17, p. 2716-28, ago. 2012.

DRUZHININA, I. S.; KOPCHINSKIY, A. G.; KUBICEK, C. P. The first 100 Trichoderma species characterized by molecular data. Mycoscience, v. 47, n. 2, p. 5564, 2006.

E. ERICKSON, L.; JENNINGS, M. Energy, Transportation, Air Quality, Climate Change, Health Nexus: Sustainable Energy is Good for Our Health. AIMS Public Health, v. 4, n. 1, p. 47-61, 2017.

FAZARY, A. E.; JU, Y. H. Feruloyl esterases as biotechnological tools: Current and future perspectives. Acta Biochimica et Biophysica Sinica, v. 39, n. 11, p. 811-828, 2007.

FINN, R. D. et al. InterPro in 2017-beyond protein family and domain annotations. Nucleic Acids Research, v. 45, n. D1, p. D190-D199, 4 jan. 2017.

FITZPATRICK, J. et al. Expression of three Trichoderma reesei cellulase genes in 
Saccharomyces pastorianus for the development of a two-step process of hydrolysis and fermentation of cellulose. Journal of Applied Microbiology, v. 117, n. 1, p. 96-108, 2014.

FLORENCIO, C. et al. Validation of a Novel Sequential Cultivation Method for the Production of Enzymatic Cocktails from Trichoderma Strains. Applied Biochemistry and Biotechnology, v. 175, n. 3, p. 1389-1402, 2014.

FORLER, D. et al. An efficient protein complex purification method for functional proteomics in higher eukaryotes. Nature Biotechnology, v. 21, n. 1, p. 89-92, 2003.

FRISCHMANN, A. et al. Self-assembly at Air/Water Interfaces and Carbohydrate Binding Properties of the Small Secreted Protein EPL1 from the fungus Trichoderma atroviride. Journal of Biological Chemistry, v. 288, n. 6, p. 4278-4287, 8 fev. 2013.

GADERER, R.; BONAZZA, K.; SEIDL-SEIBOTH, V. Cerato-platanins: A fungal protein family with intriguing properties and application potential. Applied Microbiology and Biotechnology, v. 98, n. 11, p. 4795-4803, 2014.

GALAGAN, J. E. et al. Sequencing of Aspergillus nidulans and comparative analysis with A. fumigatus and A. oryzae. Nature, v. 438, n. 7071, p. 1105-1115, 22 dez. 2005.

GARCIA-CONESA, M. T. et al. The feruloyl esterase system of Talaromyces stipitatus: Production of three discrete feruloyl esterases, including a novel enzyme, TsFaeC, with a broad substrate specificity. Journal of Biotechnology, v. 108, n. 3, p. 227-241, 2004.

GAVIN, A. C.; SUPERTI-FURGA, G. Protein complexes and proteome organization from yeast to man. Current Opinion in Chemical Biology, v. 7, n. 1, p. 21-27, 2003.

GELAIN, L.; DA CRUZ PRADELLA, J. G.; DA COSTA, A. C. Mathematical modeling of enzyme production using Trichoderma harzianum P49P11 and sugarcane bagasse as carbon source. Bioresource Technology, v. 198, p. 101-107, 2015.

GHARAHDAGHI, F. et al. Mass spectrometric identification of proteins from silverstained polyacrylamide gel: a method for the removal of silver ions to enhance sensitivity. Electrophoresis, v. 20, n. 3, p. 601-605, 1999.

GILKES, N. R. et al. Domains in microbial beta-1, 4-glycanases: sequence conservation, function, and enzyme families. Microbiological Reviews, v. 55, n. 2, p. 303-15, jun. 1991.

GIRARD, V. et al. Secretomes: The fungal strike force. Proteomics, v. 13, n. 3-4, p. 597-608, 2013.

GOLDEMBERG, J. Ethanol for a Sustainable Energy Future. Science, v. 315, n. 5813, p. 808-810, 2007.

GOMES, E. V. et al. The Cerato-Platanin protein Epl-1 from Trichoderma harzianum is involved in mycoparasitism, plant resistance induction and self cell wall protection. Scientific Reports, v. 5, n. October, p. 17998, 2015.

GÓMEZ-MENDOZA, D. P. et al. Secretomic Survey of Trichoderma harzianum Grown on Plant Biomass Substrates. Journal of Proteome Research, v. 13, n. 4, p. 1810-1822, 4 abr. 2014.

GONZALEZ-FERNANDEZ, R.; JORRIN-NOVO, J. V. Contribution of proteomics to the study of plant pathogenic fungi. Journal of Proteome Research, v. 11, n. 1, p. 3-16, 2012. 
GONZALEZ-VOGEL, A. et al. Proteomic analysis in non-denaturing condition of the secretome reveals the presence of multienzyme complexes in Penicillium purpurogenum. Applied Microbiology and Biotechnology, v. 89, n. 1, p. 145-155, 2011.

GRAILLE, M. et al. Structure-based functional annotation: Yeast ymr099c codes for a D-hexose-6-phosphate mutarotase. Journal of Biological Chemistry, v. 281, n. 40, p. 30175-30185, 2006.

GRUBER, S. G.; SEIDL-SEIBOTH, V. Self versus non-self: Fungal cell wall degradation in Trichoderma. Microbiology, v. 158, n. 1, p. 26-34, 2012.

GU, Q.; YU, L. R. Proteomics quality and standard: From a regulatory perspective. Journal of Proteomics, v. 96, n. December 2013, p. 353-359, 2014.

GUERRIERO, G. et al. Destructuring plant biomass: Focus on fungal and extremophilic cell wall hydrolases. Plant Science, v. 234, p. 180-193, 2015.

GUIGÓN-LÓPEZ, C. et al. Enzyme activity of extracellular protein induced in Trichoderma asperellum and T. longibrachiatum by substrates based on Agaricus bisporus and Phymatotrichopsis omnivora. Fungal Biology, v. 118, n. 2, p. 211-221, fev. 2014.

GUIMARÃES, L. H. S. et al. Screening of filamentous fungi for production of enzymes of biotechnological interest. Brazilian Journal of Microbiology, v. 37, n. 4, p. 474-480, 2006.

GUPTA, N.; PEVZNER, P. A. False Discovery Rates of Protein Identifications: A Strike against the Two-Peptide Rule. Journal of Proteome Research, v. 8, n. 9, p. 4173-4181, 4 set. 2009.

HAKANPAA, J. et al. Atomic Resolution Structure of the HFBII Hydrophobin, a Selfassembling Amphiphile. Journal of Biological Chemistry, v. 279, n. 1, p. 534-539, 2 jan. 2004.

HARMAN, G. E. et al. Special issue: Trichoderma - from Basic Biology to Biotechnology. Microbiology, v. 158, n. 1, p. 1-2, 1 jan. 2012.

HARVEY, A. J. et al. Comparative modeling of the three-dimensional structures of family 3 glycoside hydrolases. Proteins, v. 41, n. 2, p. 257-69, 1 nov. 2000.

HASUNUMA, T. et al. A review of enzymes and microbes for lignocellulosic biorefinery and the possibility of their application to consolidated bioprocessing technology. Bioresource Technology, v. 135, p. 513-522, 2013.

HENRISSAT, B. et al. Conserved catalytic machinery and the prediction of a common fold for several families of glycosyl hydrolases. PNAS, v. 92, n. 15, p. 7090-4, 18 jul. 1995.

HERMOSA, R. et al. Plant-beneficial effects of Trichoderma and of its genes. Microbiology, v. 158, n. 1, p. 17-25, 1 jan. 2012.

ITO, T. et al. Toward a protein-protein interaction map of the budding yeast: A comprehensive system to examine two-hybrid interactions in all possible combinations between the yeast proteins. Proceedings of the National Academy of Sciences, v. 97, n. 3, p. 1143-1147, 1 fev. 2000.

ITO, T. et al. A comprehensive two-hybrid analysis to explore the yeast protein interactome. Proceedings of the National Academy of Sciences, v. 98, n. 8, p. 45694574, 10 abr. 2001. 
JEOH, T. et al. Implications of cellobiohydrolase glycosylation for use in biomass conversion. Biotechnology for Biofuels, v. 1, n. 1, p. 10, 2008.

JONES, P. et al. InterProScan 5: genome-scale protein function classification. Bioinformatics, v. 30, n. 9, p. 1236-1240, 1 maio 2014.

KARPIEVITCH, Y. V et al. Liquid chromatography mass spectrometry-based proteomics: Biological and technological aspects. The Annals of Applied Statistics, v. 4, n. 4, p. 1797-1823, dez. 2010.

KATARIA, R.; GHOSH, S. Saccharification of Kans grass using enzyme mixture from Trichoderma reesei for bioethanol production. Bioresource Technology, v. 102, n. 21, p. 9970-9975, 2011.

KELLEY, W. D.; RODRIGUEZ-KABANA, R. Competition between Phytophthora cinnamomi and Trichoderma spp. in autoclaved soil. Canadian Journal of Microbiology, v. 22, n. 8, p. 1120-7, ago. 1976.

KIM, Y.; NANDAKUMAR, M. P.; MARTEN, M. R. Proteomics of filamentous fungi. Trends in Biotechnology, v. 25, n. 9, p. 395-400, 2007.

KNIEMEYER, O. Proteomics of eukaryotic microorganisms: The medically and biotechnologically important fungal genus Aspergillus. Proteomics, v. 11, n. 15, p. 32323243, 2011.

KOVACS, K. et al. Production of chitinolytic enzymes with Trichoderma longibrachiatum IMI 92027 in solid substrate fermentation. Applied biochemistry and biotechnology, v. 118, n. 1-3, p. 189-204, 2004.

KUBICEK, C. P. et al. Comparative genome sequence analysis underscores mycoparasitism as the ancestral life style of Trichoderma. Genome Biology, v. 12, n. 4, p. R40, 2011.

KUHAD, R. C.; GUPTA, R.; SINGH, A. Microbial Cellulases and Their Industrial Applications. Enzyme Research, v. 2011, p. 1-10, 2011.

KUMAR, R.; SINGH, S.; SINGH, O. V. Bioconversion of lignocellulosic biomass: biochemical and molecular perspectives. Journal of Industrial Microbiology \& Biotechnology, v. 35, n. 5, p. 377-391, 13 maio 2008.

LAEMMLI, U. K. Cleavage of structural proteins during the assembly of the head of bacteriophage T4. Nature, v. 227, n. 5259, p. 680-685, 1970.

LAMDAN, N.-L. et al. Secretome of Trichoderma Interacting With Maize Roots: Role in Induced Systemic Resistance. Molecular \& Cellular Proteomics, v. 14, n. 4, p. 1054 1063, abr. 2015.

LAPPALAINEN, A.; SIIKA-AHO, M.; KALKKINEN, N. Endoxylanase II from Trichoderma reesei has several isoforms with different isoelectric points. Biotechnology and Applied Biochemistry, v. 31, p. 61-68, 2000.

LATTERICH, M. Publishing proteomic data. Proteome Science, v. 4, p. 8, 2006.

LEONG, S.-L. L. et al. Genome and physiology of the ascomycete filamentous fungus Xeromyces bisporus, the most xerophilic organism isolated to date. Environmental Microbiology, v. 17, n. 2, p. 496-513, fev. 2015.

LEVASSEUR, A. et al. Expansion of the enzymatic repertoire of the CAZy database to integrate auxiliary redox enzymes. Biotechnology for biofuels, v. 6, n. 1, p. 41, 2013. 
LISTGARTEN, J.; EMILI, A. Statistical and Computational Methods For Comparative Proteomic Profiling Using Liquid Chromatography-Tandem Mass Spectrometry. Bioinformatics, p. 1-48, 2005.

LOMBARD, V. et al. The carbohydrate-active enzymes database (CAZy) in 2013. Nucleic Acids Research, v. 42, n. D1, p. 490-495, 2014.

LOPES, F. A. C. et al. Biochemical and metabolic profiles of Trichoderma strains isolated from common bean crops in the Brazilian Cerrado, and potential antagonism against Sclerotinia sclerotiorum. Fungal Biology, v. 116, n. 7, p. 815-824, jul. 2012.

LY, L.; WASINGER, V. C. Protein and peptide fractionation, enrichment and depletion: Tools for the complex proteome. Proteomics, v. 11, n. 4, p. 513-534, 2011.

MALHEIROS FERREIRA, H.; XIMENES FERREIRA FILHO, E. Purification and characterization of a $\beta$-mannanase from Trichoderma harzianum strain T4. Carbohydrate Polymers, v. 57, n. 1, p. 23-29, ago. 2004.

MANN, M. et al. The Coming Age of Complete, Accurate, and Ubiquitous Proteomes. Molecular Cell, v. 49, n. 4, p. 583-590, fev. 2013.

MANN, M.; KELLEHER, N. L. Precision proteomics: The case for high resolution and high mass accuracy. Proceedings of the National Academy of Sciences, v. 105, n. 47, p. $18132-18138,25$ nov. 2008.

MARKOVIC, O.; KOHN, R. Mode of pectin deesterification by Trichoderma reesei pectinesterase. Experientia, v. 40, n. 8, p. 842-843, 1984.

MARKOVIC, O.; SLEZÁRIK, A.; LABUDOVÁ, I. Purification and characterization of pectinesterase and polygalacturonase from Trichoderma reesei. FEMS Microbiology Letters, v. 27, n. 3, p. 267-271, 1985.

MARSH, J. A.; TEICHMANN, S. A. Structure, Dynamics, Assembly, and Evolution of Protein Complexes. Annual Review of Biochemistry, v. 84, n. 1, p. 551-575, 2 jun. 2015.

MARTINEZ, D. et al. Genome sequencing and analysis of the biomass-degrading fungus Trichoderma reesei (syn. Hypocrea jecorina). Nature Biotechnology, v. 26, n. 5, p. 553560, maio 2008.

MCDONALD, W. H.; YATES, J. R. Shotgun proteomics and biomarker discovery. Disease markers, v. 18, n. 2, p. 99-105, 2002.

MCKAY, A. M. Microbial carboxylic ester hydrolases (EC 3.1.1) in food biotechnology. Letters in Applied Microbiology, v. 16, n. 1, p. 1-6, jan. 1993.

MCQUEEN-MASON, S. J.; COSGROVE, D. J. Expansin Mode of Action on Cell Walls (Analysis of Wall Hydrolysis, Stress Relaxation, and Binding). Plant Physiology, v. 107, n. 1, p. 87-100, 1 jan. 1995.

MEINKEN, J. et al. FunSecKB2: a fungal protein subcellular location knowledgebase. Computational Molecular Biology, v. 4, n. 7, p. 1-17, 2014.

MERINO, S. T.; CHERRY, J. Progress and Challenges in Enzyme Development for Biomass Utilization. In: Biofuels. Berlin, Heidelberg: Springer Berlin Heidelberg, 2007. v. 108p. 95-120.

MICHELI, F. Pectin methylesterases: Cell wall enzymes with important roles in plant physiology. Trends in Plant Science, v. 6, n. 9, p. 414-419, 2001. 
MIYANAGA, A. et al. Crystal structure of a family 54 alpha-L-arabinofuranosidase reveals a novel carbohydrate-binding module that can bind arabinose. The Journal of biological chemistry, v. 279, n. 43, p. 44907-14, 22 out. 2004.

MOHAMED, S. A. et al. Biochemical characterization of an extracellular polygalacturonase from Trichoderma harzianum. Journal of Biotechnology, v. 127, n. 1, p. 54-64, 2006.

MONTEIRO, V. N. et al. New Insights in Trichoderma harzianum Antagonism of Fungal Plant Pathogens by Secreted Protein Analysis. Current Microbiology, v. 61, n. 4, p. 298305, 7 out. 2010.

MOREIRA, I. S.; FERNANDES, P. A.; RAMOS, M. J. Hot spots - a review of the protein-protein interface determinant amino-acid residues. Proteins, v. 68, n. 4, p. 80312, 1 set. 2007.

MOREMEN, K. W.; TIEMEYER, M.; NAIRN, A. V. Vertebrate protein glycosylation: diversity, synthesis and function. Nature Reviews Molecular Cell Biology, v. 13, n. 7, p. 448-462, 22 jun. 2012.

MUKHERJEE, P. K. et al. Trichoderma research in the genome era. Annual review of phytopathology, v. 51, p. 105-29, 2013.

MUKHERJEE, P.; MANI, S. Methodologies to decipher the cell secretome. Biochimica et Biophysica Acta - Proteins and Proteomics, v. 1834, n. 11, p. 2226-2232, 2013.

MYERS, M.; RICHMOND, R. C.; OAKESHOTT, J. G. On the origins of esterases. Molecular biology and evolution, v. 5, n. 2, p. 113-9, mar. 1988.

NORONHA, E. F.; ULHOA, C. J. Purification and characterization of an endo- $\beta-1,3-$ glucanase from Trichoderma harzianum. Canadian Journal of Microbiology, v. 42, n. 10, p. 1039-1044, 1996.

OHTSUKI, T. et al. Production of large multienzyme complex by aerobic thermophilic fungus Chaetomium sp. nov. MS-017 grown on palm oil mill fibre. Letters in Applied Microbiology, v. 40, n. 2, p. 111-116, 2005.

OLIVEROS, J. C. Venny. An interactive tool for comparing lists with Venn's diagrams. Disponível em: <http://bioinfogp.cnb.csic.es/tools/venny/index.html>.

OLLIS, D. L. et al. The $\alpha / \beta$ hydrolase fold. Protein Engineering, Design and Selection, v. 5, n. 3, p. 197-211, 1992.

PAPAGIANNI, M. Fungal morphology and metabolite production in submerged mycelial processes. Biotechnology Advances, v. 22, n. 3, p. 189-259, jan. 2004.

PAPAVIZAS, G. C. Trichoderma and Gliocladium: Biology, Ecology, and Potential for Biocontrol. Annual Review of Phytopathology, v. 23, n. 1, p. 23-54, set. 1985.

PARROU, J. L. et al. Acid trehalase in yeasts and filamentous fungi: localization, regulation and physiological function. FEMS Yeast Research, v. 5, n. 6-7, p. 503-11, abr. 2005.

PATHAK, P.; BHARDWAJ, N. K.; SINGH, A. K. Production of Crude Cellulase and Xylanase From Trichoderma harzianum PPDDN10 NFCCI-2925 and Its Application in Photocopier Waste Paper Recycling. Applied Biochemistry and Biotechnology, v. 172, n. 8, p. 3776-3797, 27 abr. 2014.

PAZZAGLI, L. et al. Cerato-Platanin, the First Member of a New Fungal Protein Family: 
Cloning, Expression, and Characterization. Cell Biochemistry and Biophysics, v. 44, n. 3, p. 512-521, 2006.

PEBERDY, J. F. Protein secretion in filamentous fungi - trying to understand a highly productive black box. Trends in Biotechnology, v. 12, n. 2, p. 50-7, fev. 1994.

PEBERDY, J. F. Extracellular proteins in fungi: a cytological and molecular perspective. Acta microbiologica et immunologica Hungarica, v. 46, n. 2-3, p. 165-74, 1999.

PEREIRA, J. L. et al. Analysis of Phaseolus vulgaris response to its association with Trichoderma harzianum (ALL-42) in the presence or absence of the phytopathogenic fungi Rhizoctonia solani and Fusarium solani. PLoS ONE, v. 9, n. 5, 2014.

POLITIS, A. et al. A mass spectrometry-based hybrid method for structural modeling of protein complexes. Nature Methods, v. 11, n. 4, p. 403-406, 9 fev. 2014.

POLIZELI, M. L. T. M. et al. Xylanases from fungi: properties and industrial applications. Applied Microbiology and Biotechnology, v. 67, n. 5, p. 577-591, 2005.

PUIG, O. et al. The tandem affinity purification (TAP) method: a general procedure of protein complex purification. Methods, v. 24, n. 3, p. 218-229, 2001.

QUALHATO, T. F. et al. Mycoparasitism studies of Trichoderma species against three phytopathogenic fungi: Evaluation of antagonism and hydrolytic enzyme production.

Biotechnology Letters, v. 35, n. 9, p. 1461-1468, 2013.

RAPPSILBER, J. The beginning of a beautiful friendship: Cross-linking/mass spectrometry and modelling of proteins and multi-protein complexes. Journal of Structural Biology, v. 173, n. 3, p. 530-540, 2011.

RAPPSILBER, J.; MANN, M.; ISHIHAMA, Y. Protocol for micro-purification, enrichment, pre-fractionation and storage of peptides for proteomics using StageTips. Nature Protocols, v. 2, n. 8, p. 1896-1906, ago. 2007.

REISINGER, V.; EICHACKER, L. A. How to analyze protein complexes by 2D blue native SDS-PAGE. Proteomics, v. 7 Suppl 1, p. 6-16, 2007.

REITER, L. et al. Protein Identification False Discovery Rates for Very Large Proteomics Data Sets Generated by Tandem Mass Spectrometry. Molecular \& Cellular Proteomics, v. 8, n. 11, p. 2405-2417, 2009.

RIBEIRO, D. A. et al. The Penicillium echinulatum Secretome on Sugar Cane Bagasse. PLOS ONE, v. 7, n. 12, p. e50571, 5 dez. 2012.

ROGOWSKA-WRZESINSKA, A. et al. 2D gels still have a niche in proteomics. Journal of Proteomics, v. 88, p. 4-13, 2013.

SADHASIVAM, S. et al. Production, purification and characterization of mid-redox potential laccase from a newly isolated Trichoderma harzianum WL1. Process Biochemistry, v. 43, n. 7, p. 736-742, jul. 2008.

SALOHEIMO, M. et al. Swollenin, a Trichoderma reesei protein with sequence similarity to the plant expansins, exhibits disruption activity on cellulosic materials. European Journal of Biochemistry, v. 269, n. 17, p. 4202-4211, 2002.

SAMUELS, G. J. Trichoderma: systematics, the sexual state, and ecology. Phytopathology, v. 96, n. 2, p. 195-206, 2006.

SCHÄGGER, H.; CRAMER, W. A.; VON JAGOW, G. Analysis of Molecular Masses and Oligomeric States of Protein Complexes by Blue Native Electrophoresis and Isolation 
of Membrane Protein Complexes by Two-Dimensional Native Electrophoresis. Analytical Biochemistry, v. 217, n. 2, p. 220-230, mar. 1994.

SCHÄGGER, H.; VON JAGOW, G. Blue native electrophoresis for isolation of membrane protein complexes in enzymatically active form. Analytical Biochemistry, v. 199, n. 2, p. 223-231, dez. 1991.

SCHMOLL, M.; SCHUSTER, A. Biology and biotechnology of Trichoderma. Applied Microbiology and Biotechnology, v. 87, n. 3, p. 787-799, 2010.

SCHWARZ, W. H. The cellulosome and cellulose degradation by anaerobic bacteria. Applied Microbiology and Biotechnology, v. 56, n. 5-6, p. 634-649, 2001.

SEIDL, M. F. et al. The Genome of the Saprophytic Fungus Verticillium tricorpus Reveals a Complex Effector Repertoire Resembling That of Its Pathogenic Relatives. Molecular Plant-Microbe Interactions, v. 28, n. 3, p. 362-373, mar. 2015.

SEIDL, V. et al. Epl1, the major secreted protein of Hypocrea atroviridis on glucose, is a member of a strongly conserved protein family comprising plant defense response elicitors. FEBS Journal, v. 273, n. 18, p. 4346-4359, 2006.

SHEVCHENKO, A. et al. Mass Spectrometric Sequencing of Proteins from SilverStained Polyacrylamide Gels. Analytical Chemistry, v. 68, n. 5, p. 850-858, jan. 1996.

SHEVCHENKO, A. et al. In-gel digestion for mass spectrometric characterization of proteins and proteomes. Nature Protocols, v. 1, n. 6, p. 2856-2860, jan. 2007.

SHI, Y. et al. The role of liquid chromatography in proteomics. Journal of Chromatography A, v. 1053, n. 1-2 SPEC. ISS., p. 27-36, 2004.

SIMS, R. E. H. et al. An overview of second generation biofuel technologies. Bioresource Technology, v. 101, n. 6, p. 1570-1580, 2010.

SINGH, A. et al. Optimal Physical Parameters for Growth of Trichoderma Species at Varying pH, Temperature and Agitation. Virology \& Mycology, v. 3, n. 1, p. 1-7, 2014.

SKINNER, O. S. et al. Native GELFrEE: A New Separation Technique for Biomolecular Assemblies. Analytical Chemistry, v. 87, n. 5, p. 3032-3038, 3 mar. 2015.

SOBOTT, F.; ROBINSON, C. V. Protein complexes gain momentum. Current Opinion in Structural Biology, v. 12, n. 6, p. 729-734, 2002.

SONI, H. et al. Screening, statistical optimized production, and application of betamannanase from some newly isolated fungi. Engineering in Life Sciences, n. September, 2016.

SPECHT, T. et al. Complete Sequencing and Chromosome-Scale Genome Assembly of the Industrial Progenitor Strain P2niaD18 from the Penicillin Producer Penicillium chrysogenum. Genome Announcements, v. 2, n. 4, 2014.

SRERE, P. Complexes Of Sequential Metabolic Enzymes. Annual Review of Biochemistry, v. 56, n. 1, p. 89-124, 1987.

ST JOHN, F. J. et al. Ligand bound structures of a glycosyl hydrolase family 30 glucuronoxylan xylanohydrolase. Journal of Molecular Biology, v. 407, n. 1, p. 92-109, 2011.

ST JOHN, F. J.; GONZÁLEZ, J. M.; POZHARSKI, E. Consolidation of glycosyl hydrolase family 30: A dual domain 4/7 hydrolase family consisting of two structurally distinct groups. FEBS Letters, v. 584, n. 21, p. 4435-4441, 2010. 
STALS, I. et al. Factors influencing glycosylation of Trichoderma reesei cellulases. I: Postsecretorial changes of the O- and N-glycosylation pattern of Ce17A. Glycobiology, v. 14, n. 8, p. 713-724, 2004.

SUÁREZ, M. B. et al. Proteomic analysis of secreted proteins from Trichoderma harzianum. Fungal Genetics and Biology, v. 42, n. 11, p. 924-934, 2005.

SWAMY, M. et al. Blue Native Polyacrylamide Gel Electrophoresis (BN-PAGE) for the Identification and Analysis of Multiprotein Complexes. Science Signaling, v. 2006, n. 345, p. pl4-pl4, 2006.

TABB, D. L. What's driving false discovery rates? Journal of Proteome Research, v. 7, n. 1, p. 45-46, 2008.

TAIZ, L.; ZEIGER, E. Plant Physiology and Development. 4th Editio ed. [s.1.] Sinauer Associates, 2009.

TAKAHASHI-NAKAGUCHI, A. et al. Genome sequence comparison of Aspergillus fumigatus strains isolated from patients with pulmonary aspergilloma and chronic necrotizing pulmonary aspergillosis. Medical Mycology, v. 53, n. 4, p. 353-60, maio 2015.

TJALSMA, H. et al. Signal peptide-dependent protein transport in Bacillus subtilis: a genome-based survey of the secretome. Microbiology and Molecular Biology Reviews, v. 64 , n. 3 , p. $515-47$, set. 2000.

URBANIEC, K. et al. A holistic approach to sustainable development of energy, water and environment systems. Journal of Cleaner Production, n. January, 2017.

VALIÑA, A. L. B.; MAZUMDER-SHIVAKUMAR, D.; BRUICE, T. C. Probing the SerSer-Lys Catalytic Triad Mechanism of Peptide Amidase: Computational Studies of the Ground State, Transition State, and Intermediate $\uparrow$. Biochemistry, v. 43, n. 50, p. 1565715672, dez. 2004.

VENKATA MOHAN, S. et al. Waste biorefinery models towards sustainable circular bioeconomy: Critical review and future perspectives. Bioresource Technology, v. 215, p. 2-12, 2016.

VITERBO, A. et al. Significance of lytic enzymes from Trichoderma spp. in the biocontrol of fungal plant pathogens. Antonie van Leeuwenhoek, v. 81, n. 1-4, p. 54956, ago. 2002.

VOS, C. M. F. et al. The toolbox of Trichoderma spp. in the biocontrol of Botrytis cinerea disease. Molecular Plant Pathology, v. 16, n. 4, p. 400-412, maio 2015.

WALZTHOENI, T. et al. Mass spectrometry supported determination of protein complex structure. Current Opinion in Structural Biology, v. 23, n. 2, p. 252-260, 2013.

WEILAND, F. et al. High resolution two-dimensional electrophoresis of native proteins. Electrophoresis, v. 35, n. 12-13, p. 1893-902, 2014.

WILKINS, M. R. et al. From Proteins to Proteomes: Large Scale Protein Identification by Two-Dimensional Electrophoresis and Amino Acid Analysis. Nature Biotechnology, v. 14, n. 1, p. 61-65, 1996a.

WILKINS, M. R. et al. Progress with proteome projects: why all proteins expressed by a genome should be identified and how to do it. Biotechnology \& Genetic Engineering Reviews, v. 13, p. 19-50, 1996 b. 
WILKINS, M. R. et al. Guidelines for the next 10 years of proteomics. Proteomics, v. 6, n. 1, p. 4-8, 2006.

WILLIAMSON, G.; KROON, P. A.; FAULDS, C. B. Hairy plant polysaccharides: a close shave with microbial esterases. Microbiology (Reading, England), v. 144 ( Pt 8, n. 4, p. 2011-23, ago. 1998.

WILSON, D. B. Three Microbial Strategies for Plant Cell Wall Degradation. Annals of the New York Academy of Sciences, v. 1125, n. 1, p. 289-297, 26 mar. 2008.

WITTIG, I.; BRAUN, H.-P.; SCHÄGGER, H. Blue native PAGE. Nature Protocols, v. 1, n. 1, p. 418-428, jun. 2006.

WU, C. C.; MACCOSS, M. J. Shotgun proteomics: tools for the analysis of complex biological systems. Current Opinion in Molecular Therapeutics, v. 4, n. 3, p. 242-50, jun. 2002.

YANG, Y. et al. Complete genome sequence and transcriptomics analyses reveal pigment biosynthesis and regulatory mechanisms in an industrial strain, Monascus purpureus YY1. Scientific Reports, v. 5, p. 8331, 2015.

ZHANG, J. et al. The role of acetyl xylan esterase in the solubilization of xylan and enzymatic hydrolysis of wheat straw and giant reed. Biotechnol Biofuels, v. 4, n. 1, p. 60, 2011.

ZHANG, J. et al. PEAKS DB: De Novo Sequencing Assisted Database Search for Sensitive and Accurate Peptide Identification. Molecular \& Cellular Proteomics, v. 11, n. 4, p. M111.010587-M111.010587, 1 abr. 2012.

ZHANG, Y. et al. Protein Analysis by Shotgun / Bottom-up Proteomics. Chemical Reviews, v. 113, n. 4, p. 2343-2394, 2013. 